DEPARTMENT OF THE INTERIOR

FrankLIN K. LANE, Secretary

United States Geólogical Survey

George Otis Smith, Director

\title{
Bulletin 698
}

\section{BIBLIOGRAPHY}

OF

\section{NORTH AMERIGAN GEOLOGY}

FOR

\section{8}

\section{WITH SUBJECT INDEX}

BY

JOHN M. NICKLES
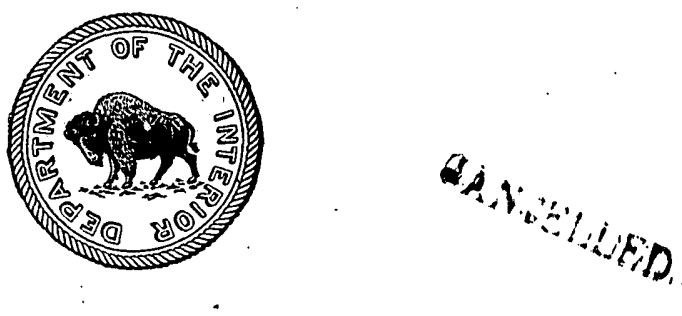

WASHINGTON

GOVERNMENT PRINTING OFFICE

1919 


\section{CONTENTS:}

Introduction

Page.

Serials examined

Bibliography

Outline of subject headings

Index

Lists

Chemical analyses

Minerals described

Rocks described.

Geologic formations deşcribed 


\title{
BIBLIOGRAPHY OF NORTH AMERICAN GEOLOGY FOR 1918, WITH SUBJECT INDEX.
}

\author{
By John M. Nichles.
}

\section{INTRODUCTION.}

The bibliography of North American geology, including paleontology, petrology, and mineralogy, for the year 1918 follows the plan and arrangement of its immediate predecessors. It includes publications bearing on the geology of the Continent of North America and adjoining islands; also Panama and the Hawaiian Islands. Papers by American writers on the geology of other parts of the world are not included. Textbooks and papers general in character by American authors are included; those by foreign authors are excluded unless they appear in American publications.

As heretofore, the papers, with full title and medium of publication and explanatory note when the title is not fully self-explanatory, are listed under the authors, arranged in alphabetic order. The author list is followed by an index to the literature listed. In this index the entries in one alphabet are of three kinds-first, subject, with various subdivisions, to enable the specialist to ascertain readily all the papers bearing on a particular subject or area; second, titles of papers, many of them abbreviated or inverted, under their leading words; and third, cross references, which have been freely used to avoid too much repetition. The subjects have been printed in blackfaced type, the titles of papers and cross references in ordinary type. As it may not be always obvious which subject headings have been adopted, an outline of those used immediately precedes the index.

The bibliography of North American geology is comprised in the following bulletins of the United States Geological Survey: No. 127 (1732-1892); Nos. 188 and 189 (1892-1900); No. 301 (1901-1905); No. 372 (1906-7); No. 409 (1908); No. 444 (1909) ; No. 495 (1910); No. 524 (1911); No. 545 (1912); No. 584 (1913); No. 617 (1914); No. 645 (1915); No. 665 (1916); No. 684 (1917); and No. 698 (1918). 
$r$

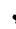




\section{SERIALS EXAMINED.}

Academy of Natural Sciences of Philadelphia: Proceedings, vol. 69, pt. 3; vol.

70, pts. 1, 2 ; Journal, 2d ser., vol. 16, pt. $4 . \quad$ Philadelphia, Pa.

Academy of Science of St. Louis: Transactions, vol. 23, no. 6. St. Louis, Mo. Alabama Geological Survey: Bulletin, no. 20. Montgomery, Ala.

American Academy of Arts and Sciences: Proceedings, vol. 53, nos. 3-10; vol. 54, nos. 1-4; Memoirs, vol. 14, no. 2. Boston, Mass.

American Association of Petroleum Geologists: Bulletin, vol. 2.

American Institute of Mining Engineers: Bulletin, nos. 133-144; Transactions, vols. 57-59. . New York.

American Journal of Science, 4th ser., vols. 45, 46. New Haven, Conn.

American Mineralogist, vol. 3. Philadelphia, Pa.

American Museum of Natural Hiștory : Bulletin, vol. 37 ; Journal, vol. 18; Memoirs, new ser., vol. 2, pt. 1; New York.

American Naturalist, vol. 52. New York.

Ameriçan Philosophical Society: Proceedings, vol. 57, nos. 1-7. Philadelphia, $\mathrm{Pa}$.

Annals and Magazine of Natural History, 9th ser. vols. 1, 2. London.

Appalachia, vol. 14, no. 3. Boston, Mass.

Arizona State Bureau of Mines: Bulletin, nos. 65, 75-93. Tucson, Ariz.

Association of American Geographers; Annals, vols. 7 and 8.

Bernice Pauahi Bishop Museum: Memoirs, vol. 5, pt. 1, vol. 6, no. 5, vol. 7, no. 1. Honolulu, Hawaiian Islands.

Botanical Gazette, vols. 65, 66. Chicago, Ill.

British Columbia, Bureau of Mines: Annual Report of the Minister of Mines for 1917. Victoria, B. C.

California Academy of Sciences: Proceedings, 4th ser., vol. 2, nos. 11, 12; vol. 7, nos. 12,13 ; vol. 8, nos. 1-7. San Francisco, Calif.

California State Mining Bureau: Bulletin, nos. 76-78, 82, 83; Preliminary report, nos. 3-5. San Francisco, Calif.

California, University of, Department of Geology : Bulletin, vol. 10, nos. 23-28; vol. 11, nos. 1-3. Seismographic Stations; Bulletin, no. 14. Berkeley, Calif.

Canada, Department of Mines, Mines Branch: Summary Report for 1917. Ottawa, Ont.

Canada, Geological Survey : Memoirs, nos. 103, 105; Museum Bulletin, nos. 27, 28 ; Summary report for 1917 , pts. B, C, D. Ottawa, Ont.

Canadian Mining Institute: Monthly Bulletin, nos. 69-80. Ottawa, Ont.

Canadian Mining Journal, vol. 39. Toronto and Montreal, Canada.

Carnegie Institution of Washington: Yearbook no. 16, for 1917. Washington, D. C.

Carnegie Museum: Memoirs, vol. 7, no. 5. Pittsburgh, Pa.

Coal Age, vols. 13, 14. New York.

Colorado School of Mines: Magazine, vol. 8; Quarterly, vol. 13 . Golden, Colo.

Connecticut Academy of Arts and Sciences: Transactions, vol. 22, pp. 249-467. New Haven, Conn.

Connecticut State Geological and Natural History Survey: Bulletin, no. 26. Hartford, Conn. 
Cuba, Dirección de Montes y Minas; Boletín de Minas, no. 4. Habana, Cuba. Economic Geology, vol. 13. Lancaster, Pa.

Elisha Mitchell Scientific Society: Journal, vol. 33, no. 4; rol. 34, nos. 1-3. Chapel Hill, N. C:

Engineering and Mining Journal, vols. 10ฐ, 106. New York.

Engineers' Club of Philadelphia : Proceedings, vol. 35. Philadelphia, Pa.

Engineers' Club of. St. Louis: Jeurnal, vol, 3. St: Eouis; Mo.

Lngineers' Society: of Western. Pennsylwania:: Prøeeedings, rol. 34: Pittsburgh, Pa.

Florida State Geologieal Surney: Tenth-Elerenth: Annuad Report. Tallahassee, Fla.

Franklin Institute: Journal, vols. 185; 186. Philadelphia, Pa:

Geographic Society of Clicago: Balletin; no: 6. Chicago, IH.

Geographical Jouinal, vols 51, 52. Lontion..

Geographical Review, vols. 5, 6. New York.

Geographical Sreciety: ofi Philadelphia : Bulletin, vol. 16: Philadelphia, Pa.

Geological Magazine, new ser., decade: 6; vol: 5. London:.

Geological Society of Almerica:: Bulletin;, vol. 2S; no. 4; vol. 29;. nos: 1-3. New York.

Geological Society of London: Quarterly Journal, vol: 73, pts: 1-3i London:

Georgia Geological Survey: Bulletin, nos:. 33, 34. Attlanta., Ga.

Harvard College, Museum of Comparative Zoology: Bulletin, vol. 61, nos. 14, 15 ;. vol.. 62 ; nos. 1-9; Mremoirs; vol. 35 ; no. 5; vol: 43 ; pt. 2 ; vol.. 45 ; no. 2. Cambridge, Mass.

Illinois Strite Geological: Survey : Bulletin. no. 9. Springfield, Ill.

Indiana Academy of Science: Proceedings for 1917. Indianapolis, Ind.

Institution of Mining and Metallurgs: Bulletin;, nos. 160-17.1. Eondon.

Institution of Mining Engineer's: Transactions, vol. 5t, pt. 4; rol. 55, pts. 1-5;

vol. 56, pts. 1-3. Newcastle: upon Tyнe, England.

Iowa Geological Survey: Bulletin no: 5: Des Moines; Iowa.

Japan, Imperial Earthquake Investigation Committee: Bulletin, rol. 9, no. 1. Tokyo, Japan.

Journal of Geographjr, vol. 16; nos. 5-10; vol: 17. nos. 1-4: Madison, Wis. Journal of Geology, vol. 26, Chicago; IH.

Kansas Academy of Sciences: Transactions, vol. 28; Bulletin no: 3. Topeka, Kans:

Fansas State Geological Survey ; Bulletin 4: Lawrence, Kans.

Kansas University Geological Survey: Bulletin. no: 3: Lawrence, Kans.

Kentucky Geological Survey: 4th ser., vol. 4, pt. 1; Shawneetown quadrangle; Mississippian. formations; State map. Frankfort, Ky.

Maryland Geological: Survey : vol. 10; Anne: Arundel. County. Baltimore, Md. Mazama, vol: 5; no. 3.. Pobtland, Oreg.

Mexico, Instituto Geológico: Boletín, nos: 3̋, 36. Mexico City, D: F. Michigan Academy of: Science : Report, Nineteenth. Lansing, Mich.

Mineral Foote-Notes, vol. 2. Philadelphia, Pa.

Mining and Metallurgical: Society of America: Bulletin, vol.. 11. New" York. Mining and Scientific Press, vols. 116, 117. San: Francisco, Calif. Mining. Congress: Journal, vol. 4; Washington, D. C.

Mining Magazine, vols: 18 ; 19 . London:

Minnesota Geological Survey: Bulletin no. 15. Minneatyolis, Minn.

Missouri Bureau of Geology and Mines: Mineral resoutces. Jefferson City, Mo. National Academy of Sciences: Proceedings, vol. 4. Washington, D. C.

National Geographic Magazine, vols. 33, 34. Washington, D. C. 
Nature, vol. 100 (no: 2514) )-vol. 102 (no: 2565). London.

Nautilus; vol: 31;, nos.. 3-4; vol.. 32; nos. 1-2: Philadelphia, Ea.

Nebraska Geological Sirvey: voli. 4; pt: 29. Lincolin, Nebr:

New York Academy of Sciences:- Annals, vol.. 28, pp. 1-50. New York.

New York Mineralogical Club: Bulletin, vol. 2, no. 1. New York.

New Yons State Musetum :: Bulletin; nos: 196-202; Albany, X:. Y.

Nortth Gurolina Geological and: Economic Survey : Economic Paper, nos. 46, 47. Raleigh, N. C.

Nova Scotia Institute of' Seience: Proceedings and 'Tiansactions, vol. 14; pt. 3 . Halifax, Nova Scotia:

Ohio Journal of Science, vol. 18, nos. 3-8; vol. 19, nos. 1, 2. Columbus, Ohio.

Oklahoma Geological Survey: Bulletin, nos. 26-30; Circulars, nos. 6-8. Norman, Okla.

Ontario Bureau of Mines: Report, vols. 26 and 27, pt. 1; Bulletin no. 34. Toronto, Ont.

Ottawa Naturalist, vol. 31 , nos. $10-12$; vol. 32 , nos. 1-6. Ottawa, Ont.

Quebec, Mines Branch: Report on mining operations, 1917. Quebec, Canala.

Rochester Academy of Science: Proceedings, vol. 5, pp. 1.61-240. Rochester, N. Y.

Joyal Society of Canada: Froceedings and Transactions, Third series, vols. 11, 12. Ottawa, Ont.

Science, new ser., vols. 47, 48. New York.

Scientific Monthly, vols. 6, 7. New York.

Scientific Society of San Antonio: 14th Annual Report. San Autonio, Tex.

Seismological Society of America : Bulletin, vol. 8. Stanford University, Calit. Sierra Club Bulletin, vol. 10, no. 3. San Francisco, Calif.

Smithsonian Institution: Smithsonian Miscellaneous Collections, vol. 67, no. 4 , vol. 68 , nos. 9-12, vol. 69, nos. 2-4, 6-8. Washington, D. C.

Sociedad científica "Antonio Alzate," Mem. y Rev.; t. 34, hos. 11-12, t. 37, no. 1, t. 38, nos. 1, 2. Mexico City, D. F.

Société de Géographie de Québec: Bulletin, vol. 12. Quebec, Canada.

South Dakota School of Mines: Bulletin no. 12. Rapid City, S. Dak.

Southern California Academy of Sciences: Bulletin, vol. 17, pts. 1, 2. Los Angeles, Calif.

Staten Island Association of Arts and Sciences: Proceedings, vol. 6, pts. 3-4. Staten Island, N. Y.

Tennessee State Geological Survey : Resources of Tennessee, vol. 8; Bulletin 20. Nashville, Tenn.

Texas, University of: Bulletin, 1803, 1816. Austin, Tex.

Torrey Botanical Club: Bulletin, vol. 45. Lancaster, Pa.

Torreya, vol. 18. Lancaster, Pa.

United States Bureau of Mines: Eighth Annual Report; Bulletin, nos. 123, 127, $129,145,146,149,151,154-157,160,161,163,164,170,171$; Technical Papers, nos. $91,139,144,152,154,170,171.182-1.87,189,190,192-195,197-$ 202, 204-206, 208. ' Washington, D. C.

Uniterl States Geological Survey: Thirty-ninth Annual Report: Professional l'aper's 104, 106, 108, 110, 114, 120 (parts) ; Bulletins 650, 655, 659, 660, $662,663,667 ; 668,670-677,680,681,684,685,686$ (parts), 690 (parts), 691. (parts) ; Water-Supply Papers 409-414, 422, 425 (parts), 426-428, 431-433, 435, 437, 438, 441., 465 ; Mineral Resources, 1917 (part). Washington, $\mathrm{D}$. C.

United States National Museum: Bulletins 99, 100, pt. 2, 102, pts. 4-7, 108, pp. 1-188; Proceedings, vol: 54 (part). Washington, D. C. 
Virginia Geological Survey: Bulletin, nos. 16, 18. Charlottesville, Va. Washington Academy of Sciences: Journal, vol. 8. Washington, D. C. Washington Geological Survey: Bulletin, no: 18. Olympia, Wash.

Washington, University of, Publications in Geology, vol. 1, no. 2. Seattle, Wash.

Western Society of Engineers: Journal, vol. 23, nos. 1-5. Chicago, Ill.

West. Virginia Geological Survey: County Reports, Barbour-Upshur-Randolph. Morgantown, W. Va.

Wyoming, Geologist's Office: Bulletin 17. Cheyenne, Wyo.

Zeitschrift für Vulkanologie, Bd. 4, H. 1, 2-3. Berlin. 


\section{BIBLIOGRAPHY.}

\section{Abbott, George.}

1. Is "Atikolcania lawsoni" a concretion? Nature, vol. 94, pp. 477-478, 1 fig., December 31, 1914.

Adams, Elliot $\mathbf{Q}$.

2. Notes on the fundamental polyhedron of the diamond lattice: Washington Acad. Sci., Jour., vol. 8, no. 8, pp. 240-241, 3 figs., April 19, 1918.

Adams, Frank Dawson.

3. Experiment in geology: Geol. Soc. America, Bull., vol. 29, no. 1, pp. 167186, March 31, 1918.

Adkinson, Henry: $M$.

4. The oil shales of Utah and Colorado: Salt Lake Min. Rev., vol. 20, no. 8, pp. 21-25, 3 figs., July 30, 1918.

Aguilar y Santillan, Rafael.

5. Bibliografía geológica y minera de la república mexicana: Appendix to Boletin Minero (Mexico, Secretaría de Industria. . .), t. 5, nos. $3-4,5-6$, t. 6 , nos. 1-2, 3, 54 pp., 1918.

Alcock, F. J.

6. Wekusko Lake area, northern Manitoba: Canada Geol. Survey, Summ. Rept. 1917, pt. D, pp. 8-17, 1918.

7. The origin of the gold deposits of Wekusko Lake: Canadian Min. Inst, Mo. Bull., no. 77, pp. 801-803, September, 1918.

Alden, William C.

8. 'The Quaternary geology of southeastern Wisconsin, with a chapter on the older rock formations: U. S. Geol. Survey, Prof. Paper 106, 356 pp., 39 pls. (incl. maps), 21 figs., 1918. Abstract, Washington Acad. Sci., Jour., vol. 8, no. 15, p, 537, September 19, 1918.

9. The country around Camp Upton [Long Island, New York]. [Text on back of topographic map], New York (Suffolk County), Moriches quadrangle (Camp Upton edition), U. S. Geol. Survey, April 1918.

10. The country around Camp Albert L. Mills [Long Island, New York].

[Text on back of topographic map], New Iork, Camp Mills quadrangle, U. S. Geological Survey, 1918.

The country around Camp Dolge. See Lees and Alden, no. 557.

Alderson, Victor $\mathrm{C}$.

11. The oil shale industry: Colorado School of Mines Quart., vol. 13, no. 2, pp. 3-30, 20 figs., April, 1918.

Allan, J. A.

12. Sections along North Saskatchewan River and Red Deer and South Saskatchewan rivers, between the third and fifth meridians: Canada Geol. Survey, Summ. Rept., 1917, pt. C, pp. 9-13, 1 pl., 1918.

Allen, Glover M.

13. Fossil mammals from Cuba: Harvard Coll., Mus. Comp. Zool., Bull., vol, 62, no. 4, pp. 133-148, 1 pl., May, 1918. 
Allen, Milton A.

14. Oil and its geology : Arizona, Bur. Mines, Bull. no. 65, 34 pp., 18 figs., 1918. Allen, M. A., and Butler, G. M.

15. Manganese : Arizona, Univ., Bur. Mines, Bull. no. 91, 32 pp., August, 1918. Alling, Harold L.

16. The Adirondack graphite deposits: New York State Mus: Bull. no: 199, 150: pp., 24: figs., (incl. nalus.), July 1, 1917.

17. Descriptive catalog of a petrographic collection of rocks from Cripple Creek, Colorado; a petrographic interpretation of the rocks of an interesting and important. region, 24 ppi, published by Ward's Natural: Science Establishment, Rochester, New York, 1918. Catalog No. 35.

Anderson; Tempest.

18. Volcanic studies in many lands ... Second series. SS pp:, 81 pls., I.ondon, John Murray, 1917.

\section{Anthony, H: E.}

19. New fossil rodents from Porto Rico; with additional notes on Elasmodontomys obliquus Anthony and Heteropsomys insulans Anthony: Am. Mus.. Nat. Hist., Bull. vol. 37, pp. 183-189, 1 pl., 1917.

20. Two new fossil bats from. Porto Rico: An. Mus. Nat. Hist. Bull., vol. 37, pp. 565-568, 1 pl., 1917.

Arnold, Ralph.

21. Topography and fault system of the region of the San Jacinto: earthquake [California] : Seismol. Soc. Ámerica, Bull., vol. 8, nos. 2-3, pp. 68-73, 1 fig., June-September, 1918.

Marine Oligocene of the west coast of North America. See Clark and Arnold, no. 173.

Ashley, George H.

22. Memorial of Albert Homer Purdue: Geol. Soc. America, Bull., vol. 29, no: 1, pp. 55-64, port., March 31, 1918.

23. Cannel coal in the United States: U. S. Geol. Survey, Bull. 659, 127 pp., 8. pls., 27 figs., 1918. Abstract, by. R. W. Stone, Washington Acad. Sci., Jour., rol: 8, no. 14, p. 502;. August 19; $191 \mathrm{~S}$.

24. The Santo Tomas: cannel coal, Webb County, Texas: U. S. Geol. Survey, Bull. 691;, pp: 251-27.0; 4 pls., 5: figs:, July 25, 1918.

Atwood, Wallace $\mathrm{W}$.

25. Relation of landslides and glacial deposits to reservoir sites in the San

Juan Mountains, Colorado: U. S. Geol. Survey, Bull. 685, 38 pp., 8 pls., 17 figs., 1918.

26. The country around Camp Devens: [Text on back of topographic map], Massachusetts, Camp Devens and vicinity, U. S. Geol. Survey, 1919.

Aurin, Fritz.

27. Geology of the red beds of Oklahoma: Oklahoma Geol. Survev, Bull. no. 30, 66 pp:, 8 pls., (incl. maps), 4 figs., September, 1917.

28. Correlation of the oil sands in Oklahoma: Oklahoma Geol. Survey, Circ. no. 7 , 16 pp., 1 pl., Oct. 1917 . 
Bagg, Rufus Mather.

29. Disconery. of fluonite in: the Ordovician limestones of Wisconsin (abstract; withi discussion: by W: A. Tarri): : Geol. Soc. America, Bull., vol. 29, no. 1, p. 104, March 31, 1918.

30: Flurorspar in the Ordovician limestone of Wiscousin: Geol: Søc: Aimerica, Bull., vol. 29, no. 3, pp. 393-398, 1 pl:,. 1 tig., September 30, 1918.

Bailey, Thomas L.

3:. Repont on the caves of the eastern: Highland Rim and: Cumberland Mountains:- Tennessee: State Geol. Survey, Resources! of Tennessee, vol:. 8; no: 2, pp. 85-138, April; 1918;.

Baker, C. L., and Bowman, W. F.

32. Geologic: explonation: of the southeastern front range of trans-Pecos Texas: Texas, Eniv:, Bull., no. 1753; pp. 61-172, 8 pls., September 20, 1917.

Baker; Frank Collins:

33. Post-glacial: Mollusca from the marls of central Illinois: Jour. Geology, vol. 26, no. 7, pp. 659-671, October-November, 1918 .

Baker, M. B:

34. Long Lake gold mine, Sudbury district: Ontario Bur. Mines, 26th Ann. Rept., 1917, vol. 26, pp. 157-162, map, 1917.

35. Alexo nickel mine, Timiskaming district: Ontario Bur.. Mines, 26th Ainn. Rept., 1917, vol. 26; pp. 258-274, 14 figsi, 1917:

Ba:li, Sydney H

36. [Notes on the occurrence of molybienum] : Inst. Min: Metal., London, Bull. no. 162, pp. 21-22, March 28, 1918.

Bancroft, J.. Austen.

37. Memorial of Charles Wales Drysdale:: Geol: Soc. America; Bull., vol. 29, no. 1, pp. 29-35, port., Mar. 31, 1918.

Bancroft, M: F.

38. Investigations in the Slocan district, British Columbia: Canada Geol. Survey; Summ: Rept. 1917, pt: B,. pp., 28-41, 1918 .

Barbour, Erwin H.

39. Preliminary report on the clay industry of Nebraska: Nebraska Geol. Survey, vol. 4, pt. 29, pp. 441-493, 2 figs., 1917.

Barrell, Joseph.

40. Rhythms and the measurements of geologic time: Geol. Soc. America, Bull., vol. 28, no. 4,.pp. 745-904, 4 pls., 6 figs., December 4, 1917.

41. The origin of the earth. In The evolution of the earth and its inliabitants [edited by R.. S: Iull];, pp. 1-44, 2: plsi, 2 figs., New Haven, Yale University Press, 1918.

42: The grow.th of knowledge of earth. structure: Am.. Tour. Sci., 4th ser., v.ol: 46, pp: 133-170, July, 1918. Reprinted in A century of scrence in America, pp. 153-192, New Haven, 1918.

Barrows, Albert L.

43. Geologic significance of fossil rock-boring animals: Geol: Soc. America, Bull., vol: 28; no. 4, pp. 965-972, December 19; 1917.

Barrows, Harlan $\mathrm{H}$.

The enviromment of Camp Grant. See: Salisbury and Barrows, no: 813. 
Barton, Donald C.

44. Notes on the Mississippian chert of the St. Louis area: Jour. Geologg, vol. 26, no. 4, :pp. 361-374, 4 figs., May-June, 1918.

Bartsch, Paul.

45. A new West Indian fossil land shell: U. S. Nat. Mus., Proc., vol. 54, pp. 60๊-606, 1 pl., 1918.

Bassler, R. S.

46. Proceedings of the ninth annual meeting of the Paleontological Society, held at Pittsburgh, Pennsylvania, December 31, 1917, and January 1 and 2, 1918: Geol. Soc. America, Bull., vol. 29, no. 1, pp. 119-160, March 31, 1918.

47. Paleozoic deposits and fossils on the Piedmont of Maryland and Virginia (abstract) : Geol. Soc. America, Bull., vol. 29, no. 1, p. 127, March 31, 1918.

48. Paleozoic rocks and fossils on the Piedmont of Maryland (abstract) :

. Washington Acad. Sci., Jour., vol. 8, no. 12, p. 411, June 19, 1918.

Bryozon of the [Panama] Canal Zone and related areas. See Canu and Bassler, no. 153.

Principles of classification of cyclostome Bryozoa (abstract). See Canu and Bassler; no. 154.

Bastin, Edson S.

49. Antimony in 1916: U. S. Geol. Survey, Mineral Resources, 1916; pt. 1, pp. 723-729, June 14, 1918.

50. War-time mineral activities in Washington: Econ. Geology, vol. 13, no. 7, pp. 524-537, November, 1918.

Pastin, Edson S., and Laney, Francis B.

51. The genesis of the ores at Tonopah, Nevada: U. S. Geol. Survey, Prof. Paper 104, 50 pp., 16 pls., 22 figs., 1918.

Bateman, Alan M.

52. A tungsten deposit near Fairbanks, Alaska: Econ. Geology, vol. 13, no. 2, pp. 112-115, March, 1918.

53. Genesis of the Sudbury nickel-copper ores (discussion) : Am. Inst. Min. Eng., Bull. no. 136, pp. 854-855, April, 1918.

See also Roberts and Longyear, no. 791.

Bates, Mowry.

54. A concrete example of the use of well $\operatorname{logs}$ - [Red River-Crichton oil field, Louisiana ] : Am. Inst. Min. Eng., Bull. no. 137, pp. 979-986, 3 figs., May, 1918.

55. The oil and gas fields of northern Louisiana: Am. Assoc. Petroleum Geologists, Bull., vol. 2, pp. 61-69, 1918.

Bather, Francis Arthur.

56. The Triassic crinoids from New Zealand: Geol. Soc. London, Quart. Jour., vol. 73, pt. 3, pp. 247-256, 15 figs., November 30, 1918.

Includes description of two species of Isocrinus from the Triassic of Alaska.

Bather, William T.

Famous mineral localities; Mt. Mica, Mt. Apatite, and other localities in Maine. See Manchester and Bather, no. 617.

Bayley, W. S. See Miller, no. 676. 
Beal, Carl H.

57. Geologic structure in the Cushing oil and gas field, Oklahoma, and its relation to the oil, gas, and water (U. S. Geol. Survey, Bull. 658, 1917) ; Abstract, by R. W. Stone, Washington Acad. Sci., Jour., vol. 8, no. 6, p. 172, March 19, 1918.

58. Geologic structure in the Cushing oil and gas field, Olklahoma: Am. Inst. Min. Eng., Trans., vol. 57, pp. 894-905, 2 figs., 1918.

Beede, J. W., and Waite, V. V.

59. The geology of Runnels County : Texas, Univ., Bull. no. 1816, 64 pp., 4 pls. (incl: map), 1 fig., March 15, 1918.

Bell, Robert N.

60. Eighteenth annual report of the mining industry of Idaho for the year 1916. 56 pp. [1917].

61. Nineteenth annual report of the mining industry of Idaho for the year 1917. 131 pp., illus., Boise, Idlaho [1918].

62. Quicksilver and antimony discoveries in central Idaho: Idaho, Mining Dept., Bull. no. 1 [12 pp.], July 25, 1918.

Benson, W. N.

63. The origin of serpentine, a historical and comparative study: Am. Jour. Sci., 4th ser., vol. 46, pp. 693-731, 4 figs., December, 1918.

Berger, Walter $\mathbf{R}$.

64. The relation of the Fort Scott formation to the Boone chert in southeastern Kansas and northeastern Oklạhoma: Jour. Geology, vọl. 26, no. 7, pp. 618-621, 1 fig. (contour map), October-November, 1918.

Berkey, Charles P.

65. Unstable conditions exhibited by some of the rock foundations of the Fudson Valley. (abstract) : New. York Acad. .Sci., Annals, vol. 27, pp. 256-257, November 30, 1917.

66. Genesis of the Sudbury nickel-copper ores (discussion) : Am. Inst. Min. Eng., Bull. no. 136, pp. 855-857, April, 1918.

67. Charles Richard Van Hise (1857-1918): Am. Mus. Jour., vol. 18, no. 8, pp. 705-706, December, 1918.

See also Roberts and Longyear, no. 791.

Berry, Edward W.

68. Notes on the history of the willows and poplars: Plant World, vol. 20, no. 1, pp. 16-28, 1 fig., January, 1917.

69. Fossil plants from the late Tertiary of Oklahoma: U. S. Nat. Mus., Proc., vol. 54, pp. 627-636, 2 pls., 1918.

70. The fossil higher plants from the Canal Zone: U. S. Nat. Mus., Bull. 103, pp. $15-44,7$ pls., 1918.

71. A restoration of Neocalamites: Am. Jour. Sci., 4 th ser., vol. 45 , pp. $445-$ 448, 2 figs., June, 1918.

71. Notes on the fern genus Clathropteris: Torrey Bot. Club, Bull., vol. 45, no. 7, pp. 279-2\$5, 2 figs., July, 1918.

The surface and underground water resources of Maryland, including Delaware and the District of Columbia. See Clark and others, no. 179.

Billingsley, Paul.

Notes on Gold Hill and vicinity, Tooele County, western Utah. See Kemp and Billingsley, no. 503. 
Billingsley, Paul, and Grimes, J. A.

73. Ore deposits of the Boulder batholith of Montana: Am. Inst. Mìn. Eng., Trans., vol. 58, pp. 284-361, 25 figs. (with discussion by W. E. Gaby, J. B. Hastings, and the authors, pp. 362-368), 1918.

Blackwelder, Eliot.

74. Characteristics of continental clastics ancl chemical denosits: Geol. Soc. America, Bull., vol. 28, no. 4, pp. 917-924, December 19, 1917.

75. The study of the sediments as an aid to the earth historian: Nat. Acall. Sei., Proc., rol. 4, no. 6, pp: 163-167, June, 1918. Abstract, feol.

Soc. America, Bull., vol. 29; no. 1, pp. S4-85, March 31, 1918.

76. New geological formations in western Wyoming: Washington Acad. Sci., Jour., vol. 8, no. 13, pp. 417-426, July 19, 1918.

77. The climatic history of Alaska from a new viewpoint: Illinois Acud. Sci., Trans., vol. 10, np. 275-280., [1918?].

See also. Rich, no. 787 .

Blackwelder, Eliot, and Crooks, H. F.

78. Pre-Cambrian rocks in the Merlicine Bow Mountains of Wyoming (abstract) : Geol. Soc. America, Bufl., vol. 29, no. 1, pp. 97-98, March $31,1918$.

Blake, John M.

79. Means of solving crystal problems: Am. Jour. Sci., 4th ser., vol. 46, pp. 651-662, 8 figs., November, 1918.

Bloesch, Edward.

80. Value of oil geology in the Mid-Continent field: Am. Assoc. Petroleum Geologists, Bull., vol. 2, pp. 124-132, 1918.

Boalich, E. S.

81. Manganese and chromium (second edition) : California State Min. Bur., Prel. Rept., no. 3, 46 pp., March, 1918.

82. Catalogue of the publications of the California State Mining Bureau, 1880-1917 : California State Min. Bur., Bull. no. 77, 44 pp., 1918.

Boalich, E. S., and Castello, W. O.

83. Tungsten, molybdennm, and vanadium : California State Min. Bur., Prel. Rept., no. 4, 34 pp., March, 1918.

84. Antimony, graphite, nickel, potash, strontinm, tin: Califoruia State Min. Bur., Prel. Rept. no. 5, 44 pp., March, 1918.

Böse, Emil.

85. Geological conditions near Bridgeport and Chico, Wise County, Texas, with special reference to the accurrence of oil: Texas, Univ., Bull. no. 1758,31 pp., October 15, 1917.

Bovee, Gladys G.

86. Bibliography and index of Wyoming geology, 1823-1916: Wyoming, Geologist's Office, Bull. 17, pp. 317-446, Cheyenne, Wyo., 1918.

Bowen, C. F.

87. Phosphatic oil shales near Dell and Dillon, Beaverhead County, Montana : U. S. Geol. Survey, Bull. 661, pp. 315-320, 1 fig., Jan. 12, 1918. Abstract, by R. W. Stone, Washington Acad. Sci., Jour., vol 8, no. 8, p. 248, April 19, 1918.

88. Stratigraphy of the Hanna Basin, Wyoming: U. S. Geol. Survey, Prof. Paper 108, pp. 227-241, 1 pl., 1 fig., May 7, 1918. 
Bowen, C. F.-Continued.

89. Structure and: oil. and gas resources of the Osage Reservation, Oklahoma, T. 24: N., R: 10 E.: U. S. Geol. Survey, Bull. 686, pp. 17-26, 2 pls. (iicl. map), 1. fig., 1918.

90. Structure and oil and gas resources of the Osage Reservation, Oklahoma ; T. 28 N., R. 9 and 10. IE.; T. 29 N., R. 10 E.: U. S. Geol. survey, Bull. 686;. pp. $43-58,2$ pls. (incl. map), 1 fig., 1918.

91. Structure and oil and gas resources of the Osage Reservation, Oklahoma; Tps. 24, 25, and 26 N., Rs. 6 and 7 E., Tps. 25 and 26 N., R. 5 E., T. 26 N., R. 4 E. : U. S. Geol. Survey, Bull. 686, pp. 137-14S, 3 pls. (incl. maps), 1918.

-92: Anticlines in a part of the Musselshell Valley, Musselshell, Meagher, and Sweetgrass counties, Montina: U. S. Geol. Survey, Bull. 691, Dp. 185-209, 1 pl. (map), November 22, 1918.

Bowen, N. L.

93. The significance of glass-making processes to the petrologist: Washington Acad. Sci., Jour., vol 8, no 4; pp 88-93; 1 fig., February 19, 1918: Abstract, Geol: Soc. Aimerica, Bull, vol. 29, no. 1, p. 102, March 31; 1918:

94. The problem of the anorthosites (Jour. Geology, vol. 25, pp. 209-243, 191.7) : Abstract, Washington Acad. Sci., Jour., vol. 8, no. 7, pl. 205-206, April 4, 1918.

Bowles, Oliver:

95. Rock quarrying for cement manufacture [notes on cement materials]: U. S. Bur. Mines, Bull. 160, 160 pp., 6 pls., 31 figs., 1918.

96. The structural and ornamental stones of Minnesota: U: S. Geol. Survey, Bull. 663, 225 pp., 21 pls; (incl. maps), 3 figs., 1918. Abstract, by R. W. Stone, Washington Acad. Sci., Jour., vol. 8, no. 13, p. 453, July $19,1918$.

Bowman, W: F.

Geologic exploration of the southeastern front range of trans-Fecos Texas. See Baker and Bowman; no. 32.

Boyd; J: T.

97. Characteristics of zinc deposits of North America (discussion): Am. Bradley, Walter W.

Inst. Min. Eng., Bull. no. 133, pp. 63-67, January, 1918.

98. Quicksilver resources of California, with a section on metallurgy and ore dressing: California State Min. Bur., Bull. no. 78, 389 pp., 42 pls. (incl. maps), 77 figs., 1918.

99. California mineral production for 1917 , with county mans: California State Min. Bur., Bull. no. 83, 179 pp., maps, August, 1918.

Bradiey, Walter W., and others.

100. Manganese and chromium in California: California State Min. Bur., Bull. no. 76, 248 pp., 51 figs., 2 pls. (maps), August, 1918.

Branson, E. B.

101. Notes on the stratigraphy and faunas of the lower Kinderhookian in Missouri (abstract): Geol. Soc. America, Bull., vol. 29, no. 1, p. 93, March 31, 1918.

102. Geology of Missouri : Missouri, Univ., Bull., vol. 19, no. 15, 172 pp., 59 figs., May, 1.91S. 
Branson, E. B., and Greger, D. K.

103. Amsden formation of the east slope of the Wind River Mountains of Wyoming and its fauna: Geol: Soc. America, Bull., vol. 29, no. 2, pp. 309-326, 2 pls., 1 fig., June 30, 1918.

Bridgman, $\mathbf{P} \cdot \mathbf{W}$.

104. The failure of cavities in crystals and rocks under pressure: Am. Jour. Sci., 4th ser., vol. 45, pp. 243-268, 8 figs., April, 1918.

\section{Brinsmade, Robert B.}

105. Iron in Santo Domingo: Min. and Sci. Press, vol. 117, pp. 35̄6-35̃8, 1 fig., September 14, 1918.

Broderick, T. M.

106. Some features of magnetic surveys of the magnetite deposits of the Duluth gabbro: Econ. Geology, vol. 13, no. 1, pp. 35-49, 8 figs., January, 1918.

Broom, R. See Gregory, no. 369.

Brown, Barnum.

107. A complete skeleton of the horned dinosaur Monoclonius, and description of a second skeleton showing skin impressions: Am. Mus. Nat. Hist., Bull., vol. 37, pp. 281-306, 9 pls., 4 figs., 1917.

108. Samuel Wendell Williston (1852-1918) : Am. Mus. Jour., vol. 18, no. 7, p. 611, port., November, 1918.

Brown, H. L., and Havward, M. W.

109. Molybdenum nifning at Climax, Colorado: Eng. and Min. Jour., vol. 105, pp. 905-907, May 18, 1918.

Brown, S. B.

110. The Saltsburg sandstone as a building stone (abstract): Science, new ser., vol. 47, pp. 467-468, May 1.0, 1918.

Bruce, E. L.

111. Amisk-Athapapuskow Lake district [Saskatchewan-Manitoba] : Canada, Geol. Survey, Mem. 105, 91 pp., map, 7 pls., 4 figs., 1918.

112. Mining in northern Manitoba: Canadian Min. Inst., Mo. Bull., no. 71, pp. 262-270, 1 fig., March, 1918.

113. Schist Lake district, northern Manitoba: Canada, Geol. Survey, Summ. Rept. 1917, pt. D, pp. 1-8, 1918.

114. Molybdenite near Falcon Lake, Manitoba: Canada, Geol. Survey, Summ. Rept. 1917, pt. D, pp. 22-25, 1918.

Bryan, William Alansen.

115. Report on the discovery of ancient glaciation on Mount Kea, Hawaii (abstract) : Science, new ser., vol. 47, p. 492, May 17, 1918.

\section{Bucher, W. H.}

116. Inorganic production of oolitic structures (abstract, with discussion by E. G. Woodruff, G. H. Cox, A. R. Crook, and E. V. Emerson) : Geol. Soc. America, Bull., vol. 29, no. 1, p. 103, March 31, 1918.

117. On oolites and spherulites: Jour. Geology, vol. 26, no. 7, pp. 593-609, 2 figs, October-November, 1918.

See also Tomlinson, no. 950 .

Buddington, A. F., and Smyth, C. H., Jr.

118. Lake Bonaparte quadrangle: New York State Mus. Bull. no. 196, pp.

Buehler, H. A. 30-32, April 1, 1917 [1918].

119. Geology and mineral deposits of the Ozark region: Am. Inst. Min. Eng., Trans., vol. 58, pp. 389-408, 4 figs., 1918. 
Buehler, H. A.-Continued.

120. Characteristics of zine deposits of North America (discussion): Am. Inst. Min. Eng., Bull. no. 133, pp. 62-63, January, 1918.

$\because$ 121. Mineral resources of Missouri: Missouri, Bur. Geology and Mines, 34 pp., illus. [1918?].

Burchard, Ernest F.

122. Iron ore, pig iron, and steel in 1916: U. S. Geol. Survey, Mineral Resources; 1916, pt. 1, pp. 507-564, 3 figs., February 13,' 1918.

123. Cement in 1916: U. S. Geol. Survey, Mineral Resources, 1916, pt. 2, pp. 341-375, January 26, 1918.

124. Fluorspar and cryólite in $1917:$ U. S. Geol. Survey, Mineral Resources, 1917 , pt. 2, pp. 293-304, 1 fig., November 20, 1918.

Burges's, J. A.

125. [Halogen seits of silver at Wonder, Nevada] (discussion) : Econ. Geology, vol. 13, no. 7. ?p. 546-549, November, 1918.

Burling, Lancaster $\mathrm{D}$.

126. Further light on the earlier stratigraphy of the Canadian Cordillera (abstract) : Geol. Soc. America, Bull., vol. 29, no. 1, pp. 145-146, March 31, 1918.

127. The A B C of fossils:- Ottawa Naturalist, rol. 32 , no. 3, pp. 43-46, September, 1918.

Rocky. Mountain section in the vicinity of Whitemans Pass (abstract). See Drysda!e and Burling, no. 268.

Burroughs, I. F.

128. Bibliography of petroleum and allied substances, 1915: U. S. Bur. Mines, Bül. 149, 147 pp., 1918.

Burrows, A. G.

129. Longuelac to Jellicoe and Orient Bay: Ontario Bur. Mines, 26th Ann. Rept., 1917, vol. 26, pp. 227-247, illus., map, 1917.

130. Gold-bearing veins in Benoit township: Ontario.Bur. Mines, 26th Ann. Rept., 1917, vol. 26, pp. 248-251, 1917.

131. Gold in Gauthier Township : Ontario Bur. Mines, 26th Ann. Rept., 1917, vol. 26 , pp. 252-257, illus., map, 1917.

132. The Matachewan gold area: Ontario Bur. Mines, 27th Ann. Rept., 1918, pp. 215-240, 14 figs., 1. map, 1918; Bull. no, 34, 30 pp., 14 figs., map, 1918.

Burton, George E.

133. The work of the petroleum geologist: Eng. and Min. Jour., vol. 105, pp. S22-824, May 4, 1918.

134. New development for oil and gas in Oklahoma during the past year and its geological significance: Am. Assoc. Petroleum Geologists, Bull., vol. 2, pp. 53-59, 1918.

Burwash, Edward Moore Jackson.

135. The geology of Vancouver and vicinity. 106 pp., 10 pls., (incl. geol. map), 12 figs., University of Chicago Press, Chicago, Illinois, 191.3.

Bustamante, Miguel.

136. El petróleo en la república mexicana; estudio geologico económico sobre los yacimientos petroliferos mexicanos:, México, Inst. Geol: Bol. no. 35, 216 pp., pls. (incl. maps), 1918.

$122541^{\circ}-19-2$ 
Butler, B. S.

137. Copper in 1916 (general report) : U. S. Geol. Survey, Mineral Resources, 1916, pt. 1, pp. 623-677, April 22, 1918:

Silver, copper, lead, and zine;, in the Central states in 1917; mines report. See Dunlop and Butler, no. 274.

Butler, G. Montague.

138. A manual of geometrical crystallography; treating solely of those portions of the subject useful in the identification of minerals. 155 pp., 107 figs., New York, John Wiley \& Sons, 1918.

139. Handbook of mineralogy, blowpipe analysis, and geometrical crystallography. Contains A pocket handbook of minerals... , 2d edition, 311 pp.; Pocket handbook of blowpipe analysis. . . 80 pp., New York, 1916; A manual of geometrical crystallography. . . . 155 pp., New York, John Wiley \& Sons, 1918.

Manganese. See Allen and Butler, no. 15.

Butts, Charles.

140. Descriptions and correlation of the Mississippian formations of western Kentucky: Kentucky Geol. Survey, Mississippian formations of western Kentucky, 119 pp., 28 pls. (incl. map), Frankfort, 1917.

141. The country in and around Camp Taylor [Kentucky]. [Text on back of topographic map], Kentucky, Camp Taylor and vicinity, U. S. Geol. Survey, 1918.

142. Geologic section of Blair and Huntingdon counties, central Pennsylvania : Am. Jour. Sci., 4th ser., vol. 46, pp. 523-537, 4 figs., Septen." ber, 1918.

Cady, Gilbert H.

143. Starved Rock State Park and its environs; geology: Geog. Soc. Chicago, Bull. no. 6, pp. 85-128, 14 figs., map, October, 1918.

Cahen, Edward.

144. Uranium: Mineral Foote-Notes, vol. 2, no. 4, pp. 2-11, April, 1918.

Calvert, Philip P.

145. Eetptions: of the Costa Rican voleano Irazk in 1917-18: Acad. Nat. Scl. Philadelphia, Proc., vol. 70, pt. 1, p. 73, 1918.

Cameron, A. E.

146. Explorations in the vicinity of Great Slave Lake: Canada, Geol. Survey, Summ. Rept., 1917, pt. C, pp. 21-28, 1918.

Campbell, Marius R.

147. The country around Camp Sherman [Ohio]. [Text on back of topographic map], Ohio, Camp Sherman quadrangle, U. S. Geol. Survey, 1918 .

Camsell, Charles.

148. Reconnaissance along the Pacific Great Eastern Railway between Squamish and Lillooet [British Columbia]: Canada, Geol. Survey, Summ. Rept. 1917 pt. B, pp. 12-23, 1 fig., 1918.

149. Indian River copper deposits, Vancouver mining division [British Columbia] : Canada, Geol. Survey, Summ. Rept. 191\%, pt B, pp. 23-25, 1918.

150. Note on the occurrence of diatomaceous earth, clay, and magnesite along the route of the Pacific Great Eastern Railway: Canada, Geol. Survey, Summ. Rept. 1917, pt. B, pp. 25-28, 1918. 
Camsell, Charles-Continued.

151. Memorial of Delorme D. Cairnes: Geol. Soc. America, Bull., vol. 29, no. 1, pp. $17-20$, port., Mirch 1, 1918 .

152. Robert Bell: Roy. Soc. Canada, Trans., $3 \mathrm{~d}$ ser., vol. 12, pp. x-xir, port., 1.91 .8$.

Canu, Ferdinand, and Bassler, R. S.

153. Bryozoa of the [Panama] Canal Zone and related areas: U. S. Nat. Mus., Bull. 108, pp. 117-122, 1 pl., 1918.

154. Principles of classification of cyclostome Bryozoa (abstract) : Geol. Soc. America, Bull., vol. 29, no. 1, p. 151, March 31, 1918.

Case, E. C.

155. Study of the vertebrate fauna and paleogeography of North America in the Permian period, with especial reference to world relations: Carnegie Inst. Washington, Year Book no. 16, 1917, p. 331, 1.91.8.

156. Permo-Carboniferous conditions versus Permo-Carboniferous time: Jour. Geology, vol. 26, no. 6, pp. 500-506, September-October, 1918.

157. A mounted skeleton of Edaphosaurus cruciger Cope, in the geological collection of the University of Michigan: Michigan, Univ., Mus. Zoology, Occ. Papers, no. 62, 8 pp., 2 pls., December 14, 1918.

Castello, W. O.

Tungsten, molybdenum, and vanadium. See Boalich and Castello, no. S3.

Anțimony, graphite, nickel, potash, strontium, tin. See Boalich and Castello, no. S4.

Chadwick, George H.

158. Stratigraphy of the New York Clinton: Geol. Soc. America, Bull., vol. 29 , no. 2, pp. $327-368$, 5 figs., June 30 , 191S.

159. Further studies in the New York Siluric (abstract) : Geol. Soc. America, Bull., vol. 29, no. 1, p. 92, March 31, 1918.

Chamberlin, Rollin $\mathrm{T}$.

160. On the mechanics of the great overthrusts (abstract): Science, new ser., vol. 47, p. 470, Maly 10, 1918.

Chamberlin, R. T., and Miller, W. Z.

161. Low-angle faulting: Jour. Geology, vol. 26 , no. 1, pp. $1-44,19$ figs., January-February, 191S.

Chamberlin, R. T., and Richards, J. T.

162. Preliminary report on experiments relating to continental deformation (abstract) : Science, new ser., vol. 47, p. 492, May 17, $191 \mathrm{~S}$.

Chamberlin, Thomas Chrowder.

163. Study of fundamental problems of geology: Carnegie Inst. Washington, Year Book no. 16, 1917, pp. 307-318, 1918.

164. Diastrophism and the formative processes; IX, A specific mode of selfpromotion of periodic diastrophism: Jour. Geology, vol. 26, 11. 3, pp. 193-197, April-May, 1918.

165. Charles Richard Van Hise, 1857-1918: Jour. Geology, vol. 26, no. 8, pp. 690-697, November-December, 1918.

Chaney, Ralph $\mathrm{W}$.

166. The ecological significance of the Eagle Creek flora of the Columbia River gorge: Jour. Geology, vol. 26; no. 7, pp. 577-592, 4 figs., October-November, 1918. 
Chapin, Theodore.

167. The structure and stratigraphy of Gravina and Revillagigedo islands, Alaska: U. S. Geol. Survey, Prof. Paper 120, pp. 83-100, 1 pl., 3 figs., August 22, 1918.

168. The Nelchina-Susitna region, Alaska: U. S. Geol. Survey, Bull. 668,67 pp., 10 pls. . (incl. maps); 4 figs., 1918.

Chase, R. L.

169. The oil shale of Colorado: Min. and Sci. Press, vol. 116, pp. 445-446, 1 fig., March 30, 1918.

Clapp, C. H. See Spencer, A. C.; no. 894.

Clapp, Frederick G.

170. Geosynclines and petroliferous deposits (discussion): Am. Inst. Min. Eng., Bull. no. 133, p. 99, January, 1918.

Clark, Bruce L.

171. Meganos group, a newly recognized division in the Eocene of California: Geol. Soc. America, Bull., vol. 29, no. 2, pp. 281-296, 2 figs., June 30, 1.918 ; Abstract, nò. 1, p. 94, March 31, 1918 .

172. The San Lorenzo series of middle California: California, Univ., Dept. Geology, Bull., vol. 11, no. 2, pp. 45-234, 22 pls., 4 figs., July 16, 1918.

See also Rich, no. 787.

Clark, Bruce L., and Arnold, Ralph.

173. Marine Oligocene of the west coast of North America: Geol. Soc. America, Bull., vol. 29, no. 2, pp. 297-308, 3 figs., June 30, 1918; Abstract, no. 1, pp. 153-154, March 31, 1918.

Clark, Frank R.

174. Structure and oil and gas resources of the Osage Reservation, Oklahoma ; 'T. 26 N., R. 9, 10, and 11 E.: U. S. Geol. Survey, Bull. 686, pp. 91-118, 5 pls. (incl. maps), 3 figs., 1918.

175. Geology of the Lost Creek coal field, Morgan County; Utah: U. S. Geol. Survey, Bull. 691, pp. 311-322, 1 pl. (map), 1 fig., 1918 [1919].

Clark, I. C.

176. Recently recognized alunite deposits at Sulphur, Humboldt County,

Nevada : Eng. and Min. Jour., vol. 106, pp. 159-163, 4 figs., July 27, 1918.

Clark, W. O.

177. Ground water for irrigation in the Morgan Hill area, California (U. S. Geol. Survey, Water-Supply Paper 400-E, 1917) : Abstract, Washington Acad. Sci., Jour., vol. 8, no. 5, pp. 128-129, March 4, 1918.

Clark, William Bullock.

178. The geography of Maryland: Maryland Geol. Survey, vol. 10, pp. 39-167, 71 figs., 1918.

Clark, William Bullock, Mathews, Edward B., and Berry, Edward W.

179. The surface and underground water resources of Maryland, including Delaware and the District of Columbia: Maryland Geol. Survey, vol. 10, pp. 169-542, 25 figs., 1918.

Clarke, F. W., and Salkover, B.

180. Note on the inorganic constituents of two small crustaceans: Washington Acad. Sci., Jour., vol. 8 no. 7, pp. 185-186, April 4, 1918. 
Clarke, John M.

181. Report on the geological survey: New York' State Mus. Bull. no. 196, pp. 24-49, 2 pis., April 1, 1917 [1.918].

182. The philosophy of geology and the order of the state: Nerv York State Mus. Bull. no. 196, pp. 93-106, April 1, 1917 [1.91.8].

183. Devonian glass sponges: New York State Mus. Bull. no. 196, pp. 177198, 6 pls., April 1, 1917 [191S].

184. Strand and undertow markings of. upper Devonian time as indications of the prevailing climate: New York State Mus. Bull. no. 196, pp. 199-238, 23 pls., April 1, 1917 [1918]. Abstract, Geol. Soc. America, Bull., vol. 29 , no. 1 , p. 83 , March 31 , 1918 .

185. Primary and secondary stresses recorded by the vein systems in the Percé rock: New York State Mus. Bull. no. 196, pp. 239-240, 3 pls., April 1., 1917 [1.91.S].

186. Memorial of William Bullock Clark: Geol. Soc. America, Bull, yol. 29, no. 1, pp. 21-29, port., March 31, 1918.

187. Possible derivation of the lepadid barnacles from the phyllopods: Nat. Acad. Sci., Proc. vol. 4, no. 12, pp. 384-386, December, 1918.

Clements, Frederic C.

188. Scope and significance of paleo-ecology: Geol. Soc. America, Bull., vol. 29 , м.. 2 , pp. 369-374, June-30, 1918.

Cockerell, T. D. $\dot{A}$.

189. New species of North American fossil beetles, cockroaches, and tsetse flies : U. S. Nat. Mus., Proc., vol. 54, pp. 301-311, 2 pls., 5 figs., 1918.

190. Invertebrate paleontology: Science, new ser., vol. 47, pp. 319-320, March 29, 1918.

Cockfield, William E.

191. Explorations in Yukon Territory: Canada, Geol. Survey, Summ. Rept. 1917, pt. B, pp. 1-9, 1918.

Cole, G. G.

192. The Holmesville, Ohio, glacial terrace and moraine (abstract) : Science, new ser., vol. 47, p. 469, Mày 10, 1918.

Cole, L. Heber.

193. Occurrence and testing of foundry moulding sands: Canada, Dept. Mines, Mines Branch, Bull. no. 21, 17 pp., 3 pls., 2 figs., 1917.

194. Investigation of certain sand and sandstone deposits: Canada, Dept. Mines, Mines Branch, Summ. Rept. 1917, pp. 51-52, 1918.

Coleman, A. P.

195. Geology of the Toronto region. In The natural history of the Toronto region, Ontario, Canada, ed. by J. H. Faull, pp. 51-81, 2 pls., map, Toronto, published by the Canadian Institute, 1913.

196. La pẹninsule du Labrador: Soc. geographie Québec, Bull., vol. 12, no. 3, pp. 143-145, May-June, 1918.

See also Ekblaw, no. 278; Wilson, no. 1060.

Collier, Arthur J.

197. The Bowdoin dome, Montana, a possible reservoir of oil or gas (U. S. Geol. Survey, Bull. 661-E, 1917) : Abstract, by R. W. Stone, Washington Acad:- Sci., Jour., vol. 8, no. 2, p. 36, January 19, 1918.

198. A formation hitherto unaccounted for in North Dakota (abstract): Washington Acad. Sci., Jour., vol. 8, no. 12, pp. 412-413, June 19,1918 . 
Collier, Arthur J.-Continued.

199. The Nesson anticline, Williams County, North Dakota: U. S. Geol. Survey, Bull. 691, pp. 211-217, 1 pl. (map), August 15, 1918.

200. Geology of northeastern Montana: U. S. Geol. Survey, Prof. Paper 120, pp. 17-39, 6 pls. (incl. map), 5 figs., December 12, 1918.

Collier, Arthur: J., and Thom, W. T., Jr.

201. The Flaxville gravel and its relation to other terrace gravels of the northerñ Great Plains: U. S. Geol. Survey, Prof. Paper 108, pp. . 179-184, 4 pls. (incl. map), 1 fig., January 26, 1918. Abstract by R. W. Stone, Washington Acad. Sci., Jour., vol. 8, no. 8, p. 249, April 19, 1918.

Condit D. Dale.

202. Relations of late Paleozoic and early Mesozoic formations of southwestern Montana and adjacent parts of Wyoming: U. S. Geol. Survey, Prof. Paper 120, pp. 111-121, 5 pls. (incl. map), 1 fig., October 21, 1918.

Condra, G. E.

203. Preliminary report on the potash industry of Nebraska : Nebraska Univ., Nebraska Conservation and Soil Survey, Bull. 8, 39 pp., 18 figs., 1918.

Cooke, Charles Wythe.

204. Orbitoid Foraminifera of the genus Orthophragmina from Georgia and Florida (U. S. Geol. Survey, Prof. Paper 108-G, 1917) : Abstract, Washington Acad. Sci., Jour., vol. 8, no. 4, p. 96, February 19, 1918.

205. Correlation of the deposits of Jackson and Vicksbuirg ages in Mississippi and Alabama: Washington Acad. Sci., Jour., rol. 8, no. 7, pp. 186-198, April 4, 1918.

Cooke, Charles $W_{y}$ the, and Shearer, Harold Kurtz.

206. Deposits of Claiborne and Jackson age in Georgia: U. S. Geol. Surves, Prof. Paper 120, pp. 41-81, 1 pl. (map), 3 figs., June 4, 191. . Abstract, Washington Acad. Sci., Jour., rol. 8, no. 15, p. 540, September 19, 1918.

Coolbaugh, W. F.

207. Potash: Colorado School of Mines Mag., vol. 8, no. 6, pp. 97-o9, June, 1918.

Coste, Eugene.

208. Principles and problems of oil prospecting in the Gulf coast country (discussion) : Am. Inst. Min. Eng., Bull. no. 136, pp. 830-832, April, 1918.

See also Matteson, no. 634 .

Cotton, C. A.

209. Conditions of deposition on the continental shelf and slope: Jour. Geology, vol. 26, no. 2, pp. 135-160, 8 figs., February-March, 1918.

Cox, G. H. See Bucher, no. 116.

Craig, E. H. Cunningham.

210. The prospective oil fields of Barbados: Inst. Petroleum Techuologists, Jour., vol. 4, no. 14, pp. 68-78, 2 figs., February, 1918.

Crider, A. F.

211. The coals of Letcher County: Kentucky Geol. Survey, 4th ser., vol. 4, pt. 1, 234 pp., 2 pls., 1 fig., 2 maps, Frankfort, Ky., 1916. 
Crook, A. R.

212. Additional note on Monks Mound (abstract, with discussion by J. E. Todd) : Geol. Soc. America, Bull., vol. 29, no. 1, pp. 80-\$1, March, 31, 1918.

See also Bucher, no. 116; Tomlinson, no. 950.

Crooks, Harold F.

Pre-Cambrian rocks in the Medicine Bow Mountains of Wyoming (abstract). See Blackwelder and Crooks, no. 78.

Types of North America Paleozoic oolites (abstract). See Van Tuyl and Crooks, no. 973.

Early Silurian rocks of the northern Peninsula of Michigan. See Savage and Crooks, no. 818.

Cullen, John.

213. Lime resources and industry in Oklahoma: Oklahoma Geol. Survey, Bull. no. 26, 70 pp., 10 figs., map, August, 1917.

Cushing, H. P.

214. The Gouverneur quadrangle: New York State Mus. Bull. no. 196, pl. 24-29, April 1, 1917 [1918].

Cushman, Joseph Augustine.

215. Some Pliocene and Miocene Foraminifera of the Coastal Plain of the United States: U. S. Geol. Survey, Bull, 676, $100^{\circ}$ pp., 31 pls., 1918.

216. Contributions to the geology and paleontology of the Canal Zone, Panama, and geologically related areas in Central America and the West Indies; The smaller fossil Foraminifera of the Panama Canal Zone: U. S. Nat. Mus., Bull. 103, pp. 45-87, 15 pls., 1918.

217. The larger fossil Foraminifera of the Panama Canal Zone: U: S. Nat. Mus., Bull. 103, pp. 89-102, 12 pls., 1018.

Dake, C. L.

218. The Hart Mountain overthrust and associated structures in Park County, Wyoming: Jour. Geology, vol. 26, no. 1, pp. 45-55, 1 fig., JanuaryFebruary, 1918.

219. The Valley City graben, Utah : Jour. Geology, vol. 26, no. 6, pp. 569-573, 4 figs., September-October, 1918.

Dall, William Healey.

220. Reminiscences of Alaskan volcanoes: Sci. Monthly, vol. 7, no. 1, pp. 80-90, 3 figs., July, 1918.

221. Pleistocene fossils of Magialena Bay, Lower California, collected by Charles Russell Orcutt: The Nautilus, vol. 32, no. 1, pp. 23-26, July, 1918.

Daly, Marcel R.

222. Geosynclines and petroliferous deposits: Am. Inst. Min. Eng., Trans., vol. 57, pp. 1054-1065, 6 figs. (with discussion by $W$. van der Gracht, Frederick G. Clapp, and the author, pp. 1065-1070), 1918 ; discussion (by the author), Bull. no. 135, pp. 695-700, March, 1918.

223. Water surfaces in the oil fields: Am. Inst. Min. Eng., Bull. no. 133, pp. 151-1.57, 4 figs., January, 1918; Trans., vol. 59, pp. 5்7-563, 1918.

Daly, Reginald A.

224. 'Thirteen-foot model of the world's most active rolcano [Kilanea, Hawaii] : Sci. Am., vol. 11., pp. 132, 137-138, February 9, 191.8. 
Daly, Reginald A.-Continued.

225. Genesis of the alkaline rocks: Jour. Geology, vol. 26, no. 2, pp. 97-1.34, February-March, 1918.

226. Field relations of litchfieldite and soda syenites of Litchfield, Maine: Geol. Soc. Anerica, Bull., vol. 29, no. 1, p. 99 (abstract), March 31, no. 3, pp. 463-470, 2 figs., September 30, 1918.

Dana, Edward Salisbury, and others.

226a. A century of science in America, with special reference to the American Journal of Science, 1818-1918. 458 pp., pls. (portraits), New Haven, Yale University Press, 1918.

- Reproduced with some additions from the Centennial Number, 1818-1918 (July, 1918) of the American Journal of Science. The contributions relating to geology have been entered under the individual authors. ,

Darton, N. H.

227. The structure of parts of the central Great Plains: U. S. Geol. Survey, Bull. 691, pp. 1-26 ; 4 pls., 18 tigs., April 2, 1918. Abstract, Washington Acad. Sci., Jour., vol. 8, no. 14, p. 503, August.19, 1918.

228. Artesian waters in the vicinity of the Black Hills, South Dakota: U. S. Geol. Survey, Water-Supply Paper 428, 64 pp., 13 .pls. (incl. nap), 11 figs., 1918.

229. Structure of some mountains in New Mexico (abstract) : Geol. Soc. America, Bull., vol. 29, no. 1, p. 72, March 1, 1918.

Davis, E. F.

230. The Franciscan sandstone: California, Univ., Dept. Geology, Bull., vol. 11, no. 1, pp. 1-44, 2 pls., 6 figs., March 20, 1918.

231. The registration of earthquakes at the Berkeley Station and at the Lick Observatory Station from April 1, 1917, to September 30, 1917: California, Univ., Seismographic Stations, Bull. no. 14, pp. 297-324, May 23, 1918.

232. The radiolarian cherts of the Franciscan group: California, Univ., Dept. Geology, Bull., vol. 11, no. 3, pp. 235-432; 12 pls., 16 figs., December 23, 1918.

Davis, J. A.

Mining and concentration of carnotite ores. See Kithil and Davis, no. 522 .

Davis N. B.

233. Report on the clay resources of southern Saskatchewan : Canada, Dept. Mines, Mines Branch, 93 pp., 21 pls., 1 fig., 2 maps, 1918.

Davis, W. M.

234. Coral reefs and submarine banks: Jour. Geology, vol. 26, no. 3, pp. 198-223, 4 figs., April-May; no. 4, pp. 289-309; May-June; no. 5, pp. 385-411, July-August, 1918.

235. Geological terms in geographical descriptions: Science, new ser., vol. 48, pp. 81-84, July 26, 1918.

236. The Cedar Mountain trap ridge near Hartford: Am. Jour. Sci., 4th ser., vol. 46, pp. 476-477, August, 1918.

237. Subsidence of reef-encircled islands: Geol. Soc. America, Bull., vol. 29, no. 1, pp. 71-72 (abstract), March 31, no. 3, pp. 489-574, 17 figs., September 30, 1918.

238. Grove Karl Gilbert: Am. Jour. Sci., 4th ser., vol. 46, pp. 669-681, November, 1918. 
Dean, Bashford.

239. Charles Rochester Eastman (1868-1918) : Am. Mus. Jour., vol. 18, no. 6, pp. 506-507, October, 1918.

Dean, Reginald s.

240. The formation of Missouri cherts: Am. Jour. Sci., 4th ser., vol. 45, pp. 411-415, May, 1918.

DeGolyer, E.

241. The geology. of Cuban petroleum deposits: An. Asșoc. Petroleum Geologists, Bull., vol. 2, pp. 133-167, 1918.

242. Possible oil and gas fields in the Cretaceous beds of Alabama (discussion ) : Am. Inst. Min. Eng., Bull. no. 136, pp. 819-822, April, 1918.

243. The theory of volcanic origin of salt domes: Am. Inst, Min. Eng., Bull. no. 137, pp. 9S7-1000, May, 1918. Discussion by J. A. Udden, Bull. no. 139 , p. 1147, July, 1918.

244. The significance of certain Mexican oil field temperatures: Econ. Geology, vol. 13, no. 4, pp.' 275-301, June, 1918.

245. Oil in southern Tamaulipas, Mexico (discussion) : Am. Inst. Min. Eng., Bull. no. 142, pp. 1560-1564, 1. fig., October, 1918.

246. Origin of the cap rock of the Gulf coast salt domes (discussion): Econ. Geology, vol. 13, no. 8, pp. 616-620, December, 1918.

De Kalb, Courtenay.

247. Ajo copper mines [Pima County, Arizona]: Min. and Sci. Press., vol. 116, pp. 115-119, 7 figs., January 26, 1918.

248. Sacramento Hill disseminated copper deposit [Bisbee, Arizona]: Min. and Sci. Press, vol. 116, pp. 549-554, 578-583, 9 figs., April 20 and 27, 1918.

DeLury, Justin S.

249. Tungsten ore deposits near Falcon Lake, Manitoba: Canadian Min. Jour., vol. 39, no. 11, pp. 186-188, 6 figs., June 1, 1918.

The mineral belt north of The Pas [Manitoba]. See Wallace and DeLury, no. 990.

Denis, Theo. C.

250. Report on mining operations in the Province of Quebec during the year 1917: Quebec (Province), Dept. of Colonization, Mines, and Fisheries, 147 pp., 6 pls., 4 figs., map, Quebec, 1918.

Deussen, Alexander.

251. Review of developments in the Gulf coast country in 1917: Am. Assoc. Petroleum Geologists, Bull., vol. 2, pp. 16-37, 5 tigs., 1918.

Dick, James E.

252. The Whitepine section of the Tomichi district [Gunnison County, Colorado] : Eng. and Min. Jour., vol. 106, pp. 331-333, 2 tigs., August 24, 1918.

Dickerson, Roy E.

253. Mollusca of the Carrizo Creek beds and their Caribbean aftinities (abstract) : Geol. Soc. America, Bull., vol. 29, no. 1, p. 148, March 31, 1918.

254. Proposed correlation of the Pacific and Atlantic Eocene (abstract): Geol. Soc. America, Bull., vol. 29, no. 1, pp. 14\&-149, March, 31, 1918: 
Dickerson, Roy E.-Continued.

255. Occurrence of the Siphonalia sutterensis zone, the uppermost Tejon horizon in the outer Coast Ranges of California (abstract) : Geol. Soc. America, Bull., vol. 29, no. 1, p. 163, March 31, 1918.

Diller, J. S.

256. Asbestos, what it is and does for us: Tractor and Gas Engine Review, vol. 11, no. 4, pp. 10-11, April, 1918.

257. Chromite in 1917: U. S. Geol. Survey, Mineral Resources, 1917, pt. 1, pp. $37-47$, August 8, 1918 .

258. Talc and soapstone in 1917: U. S. Geol. Survey, Mineral Resources, 1917, pt. 2, pp. 81-84, July 12, 1918.

259. Asbestos in 1917 : U. S. Geol. Survey, Mineral Resources, 1917, pt. 2, pp. 197-204, 3 figs., September 18, 1918.

Dolmage, $V$.

260. The copper silver veins of the Telkwa district, British Columbia: Econ. Geology, vol. 13, no. 5, pp. 349-3\$0, 2 pls., 2 figs., July, 1918.

\section{Douthitt, Herman.}

261. The structure and relationships of Diplocalus: [Chicago, University], Walker Museum, Contr., vol. 2, no. 1, pp. 3-41, 2 pls., 7 figs., 1917.

Dowling, D. B.

262. Water supply in southern Alberta: Canada Geol. Survey, Summ. Rept., 1917, pt. C, pp. 1-3, 1918.

263. Fotash in saline waters in Saskatchewan: Canada Geol. Survey, Summ. Rept., 1917, pt. C, pp. 3-4, 1918.

264.Viking-Athabaska gas field: Canadil Geol. Survey, Summ. Rept., 1917, pt. C, pp. 5-6, 1918.

265. Preliminary study of the western gas fields of Canada: Roy. Soc. Canada, Trans., ser. 3, vol. 12, sec. 4, pp. 89-94, 1 pl., June and September, 1918.

Drake, N. F.

266. Report on the Colorado coal field of Texas. (Reprint from the Fourth annual report of the Geological Survey of Texas.) Texas, Univ., Bull. no. 1755, 3 pls. (incl. map), October 1, 1917.

Dresser, J. A. See Taber, no. 924.

Dryer, Charles R.

267. The physiography of Indianapolis: Indiaua Acad. Sci., Proc., 1917, pp. $55-57,1$ fig. (map), 1918.

Drysdale, C. W., and Burling, L. D.

268. Rocky Mountain section in the vicinity of Whitemans Pass (abstract) : Geol. Soc. America, Bull., vol. 29, no. 1, p. 145, March 31, 1918.

Duce, James Terry.

269. The effect of cattle on the erosion of canyon bottoms: Science, new ser., vol. 47 , pp. $450-452$, May $10,1918$.

Dumble, E. T.

270. Funnel and anticlinal ring.structure associated with igneous intrusions in Mexican oil fields (discussion) : Am. Inst. Min. Eng., Bull. no. 133, p. 92, January, 1918. 
Dumble, E. T.-Continued.

271. Geology of the northern end of the Tampico embayment area: California Acad. Sci., Proc., 4th ser., vol. 8, no. 4, pp. 113-156, 4 pls. (incl. map), July 19, 1918.

272. Origin of the Texas domes: Am. Inst. Min. Eng., Bull. no. 142. pp. 1629-1636, October, 1918.

Dunbar, Carl O.

273. Stratigraphy and correlation of the Devonian of western Tennessee: Am. Jour. Sci., 4th ser., vol. 46, pp. 732-756, 1 fig. (malp), December, 1918.

Dunlop, J: P.

Gold and silver in 1916 (general report). See McCaskey and Dunlop, no, 603 .

Dunlop, J. P., and Butler, B. S.

274. Silver, copper, lead, and zinc in the Central states in 1917; mines report: U. S. Geol. Survey, Mineral Resources, 1917, pt. 1, pp. 73-130; October 24, 1918.

Eakin, Henry M.

275. The Cosna-Nowitna region, Alaska: U. S. Geol. Survey, Bull. 667, 54 pp., S pls. (incl. maps), 3 figs., 1918. Abstract by $R$. W: Stone, Washington Acal. Sci., Jour., vol. 8, no. 14, p. 502, August 19, 1918.

Eastman, Charles R.

276. Dentition of Hydrocyon and its supposed fossil allies: Am. Mus. Nat. Hist., Bull., vol. 37, pp. $757-760,4$ pls., 3 figs., 1917.

Eggleston, Julius Wonster.

277. Eruptive rocks at Cuttingsville, Vermont: Am. Jour. Sci., 4th ser., vol. 45, pp. 377-410, 5 tigs., May, 1918.

Ekblaw, W. Elmer.

278. Opportunities for geological work in the far Arctic (abstract, with discussion by A. P. Coleman and E. O. Hovey) : Geol. Soc. America, Bull., vol. 29, no. 1., pp. 85-86, March 31, 1918.

279. The importance of nivation as an erosive factor, and of soil flow as a transporting agency, in northern Greenland: Nat. Acad. Sci., Proc., vol. 4, no. 9, ํ. 28S-293, September, 1918. Abstract, Geol. Soc. America, Bull., vol. 29, no. 1, pp. 72-73, March 31, 1918.

See also Fairchild, no. 297.

Ellis, Arthur .T.

280. Mineral waters in 1916: U. S. Geol. Survey, Mineral Resources, 1916, pt. 2, pp. 463-510, 1 fig., March 13, 1918.

Elston, E. D.

281. Potholes, their variety, origin, and significince: Sci. Monthly, vol. 5, no. 6 , pp. 554-567; vol. 6, no. 1, pp. 37-53, 23 figs., December, 1917 and January, 1918.

Elworthy, R. T.

282. Mineral springs of Canada; part II, The chemical character of some Canadian mineral springs: Canada, Dept. Mines, Mines Branch, 173 pp., 10 pls., 2 figs., 191S. 
Emerson, B. K:

283. Geology of Massachusetts and Rhode Island (.U. S. Geol. Survey, Bull. 597, 1917) : Abstract, bỹ R. W. Stone, Washington Acad. Sci., Jour., vol. 8, no. 7, p. 204, April 4, 1918.

Emerson, Edward H.

284. Geología de las minas [Cobre, Oriente, Cuba]: Boletín de Minas, Habana, no. 4, pp. 47-51, 1 pl., January, 1918.

Emerson, F. V.

285. Loess-depositing winds in the Louisiana region (abstract): Geol. Soc. America, Bull., vol. 29 , no. 1 , p. 79 , March $31,1918$.

286. Loess-depositing winds in Louisiana: Jour. Geology, vol. 26, no. 6, pp. 532-541, 4 figs., September-October, 1918.

See also Bucher, no. 116 .

Emery, Wilson B.

287. Structire and oil and gas resources of the Osage Reservation, Oklahoma, T. 23 N., R. 11 E.; Tps. 22 and 23 N., R. 12 E. : U. S. Geol. - Survey, Bull. 686, pp. 1-9, 2 pls. (incl. map), 2 figs., 1918.

288. The Green River Desert section; Utah: Am. Jour. Sci., 4th ser., vol. 46, pp. 551-577, 3 figs. (incl. map), October, 1918.

Emig, W. H.

289. Travertine deposits of Oklahoma: Oklahoma Geol. Survey, Bull. no. 29, 76 pp., 14 pls., 5 figs.; August, 1917.

290. The travertine deposits of the Arbuckle Mountains, Oklahoma (abstract) : Science, new ser., vol. 47, p. 468, May 10, 1918.

Emmons, William Harvey.

291. Exploration of metalliferous deposits : Am. Inst. Min. Eng., Trans., vol. 58 , pp. $232-243,1918$.

292. The principles of economic geology. 606 pp.; 210 figs., New York, McGraw-Hill Book Company, 1918. Review, by Joseph T. Singewald, Jr., Econ. Geology, vol. 13, no. 4, pp. 325-332, June, 1918.

293. Discussion of a paper headed "Genetic classification of underground volatile agents," [by R. A. Daly]; Econ. Geology, vol. 13, no. 2, pp. 144-145, 1 fig., March, 1918.

See also Tarr, no. 929.

English, Walter A.

294. Geology and oil prospects of the Salinas Valley-Parkfield area, California: U. S. Geol. Survey, Bull. 691, pp. 219-250, 2 pls., 2 figs., June 18, 1918. Abstract, by R. W. Stone, Washington Acad. Sci., Jour. vol. 8, no. 15, p. 539, September 19, 1918.

\section{Faribanks, Ernest E.}

295. Method of indexing a mineral collection: Am. Mineralogist, vol. 3, no. 11, p. 195, November, 1918.

Fairchild, Herman Leroy.

296. Postglacial continental uplift: Science,.new ser., vol. 47, pp. 615-617, 1 tig. (map), June 21, 1918.

297. Postglacial uplift of northeastern America (abstract with discussion by Frank Leverett and W. Elmer Ekblaw) : Geol. Soc. America, Bull., vol. 29 , no. 1 , pp. 70-71, March $31,1918$.

298. Postglacial uplift of northeastern America: Geol. Soc. America, Bull., vol. 29, no. 2, pp. 1S7-238, 9 pls., 1 fig., June 30,1918 . 
Fairchild, Herman Leroy-Continued.

299. Glacial depression and postglacial uplift of northeastern America : Nat.

Acad. Sci., Proc., vol. ,4, no. 8, pp. 229-232, 1 fig., August, 1918.

300. Grove Karl Gilbert: Science, new ser., vol. $\cdot 48, \ldots$ pp. 151-154, August 16, 1918.

Fansett, George $R$.

301. Field tests for the common metals in minerals: Arizona, Univ., Bur. .. Mines, Bull. no: 93, pp. 20, November, 1918."

Fath, A. E.

302. Structure of the northern part of the Bristow quadrangle, Creek County, Oklahoma, with reference to petroleum and natural gas (U. S. Geol. Survey, Bull. 661-B, 1917) : Abstract, by R. W. Stone, Washington Acad. Sci., Jour., vol. 8, no. 2, pp. 37-38, January 19, 1918.

Fenton, Carroll Lane.

303. A prominent mud-crack horizon of the Cedar Valley stage of the Iowa Devonian: Ottawa Naturalist, vol. 32 , no. 6, pp. 113-115, 1 fig., December, 1918.

Ferguson, Henry G.

304. Tin deposits of Irish Creek: Eng. and Min. Jour., vol. 105, pp. 5-7, January 5, 1918.

305. Tin in Virginia: Science, new ser., vol. 47, p. 529, May 31, 1918 . ...

306. Tin deposits near Irish Creek, Virginia: Virginia Geol. Survey, Bull, no. XV-A, 19 pp., 3 figs., 1918.

307. Graphite in 1917 : U. S. Geol. Survey, Mineral Resources, 1917, pt. 2, pp. 97-119, 1 fig., July 26, 1918.

Ferguson, J. B., and Merwin, H. E.

308. The melting points of cristobalite and tridymite: Am. Jour. Sci, 4th ser., vol. 46, pp. 417-426, 2 figs., August, 1918.

Fernández de Castro, Manuel, and Salterain y Iegarra, Pedro. Geological map of Cuba. See Hayes and others, no. 421.

Fettle, Charles R.

309. The glass sands of Pennsylvania: Science, new ser., vol. 48 , pp. $98-100$, July 26, 1918 .

Fettke, Charles R., and Hubbard, Bela.

310. The limonite deposits of Mayaguez Mesa, Porto Rico: Am. Inst. Min. Eng., Bull. no. 135, pp. 661-676, 8 tigs., March, 1918.

Finlay, George I.

311. The geology of North Park, Colorado (abstract) : New York Acad. Sci., Annals, vol. 27, p. 272, November $30,1917$.

Finlay, J. R.

312. The Southwest copper field [New Mexico-Arizona-Sonora]: Eng. and Min. Jour., vol. 106, pp. 199-205, 3 figs., August 3, 1918.

313. The Jerome dịstrict of Arizona: Eng. and Min. Jour., vol. 106, pp. $557-562,605-610,2$ figs., September 28 and October 5, 1918.

Flores, Teodoro.

314. El tequesquite del Lago de Texcoco: México, Inst. Geol, Anales, no. 5, pp. 1-14, 16 pls., 1918:

Foerste, A. F.

315. The Richmond faunas of Little Bay de Noquette in northern Michigan: Ottawa Naturalist, vol. 31 , no. 10, pp. 121-127, Jànuary, 1918. 
Ford, William E.

316. New mineral names: Am. Jour. Sci., 4th ser., vol. 45, pp. 477-478, June, 1918.

317. The growth of mineralogy from 1818 to 1918: Am. Jour. Sci., 4th ser., vol. 46 , pp. $240-254$, July, 1918 . Reprinted in A century of science in America, pp. 268-283, New Haven, 1918.

Foshag, William.

3i18. Ulexite from Lang, California: Am. Mineralogist; vol. 3, no. 4, p. 35, April, 1918.

Foye, Wilbur G.

319. Notes on a collection of rocks from Honduras, Central America: Jour. Geology, vol. 26, no. 6, pp. 524-531, 1 fig., September-October, 1918.

Frechette, Howells.

320. Limestones of Ontario; Canada, Dept. Mines, Mines Branch, Summ. Rept. 1917, pp. 23-48, 1918.

Frick, Childs.

321. Fauna of the Bautista Creek badlands (abstract): Geol. Soc. America, Bull., vol. 29, no. 1, p. 163, March 31, 1918.

Friedlaender, Immanuel.

322. Regelmässigkeit der Abstände vulkanischer Eruptionszentren. [regularity of intervals of centers of volcanic eruption] : Zeitschr. Vulkanologie, Bd. 4, H. 1, pp. 15-32, 8 pls., 1 fig., April, 1918.

323. Ueber den vulkanischen Ausbruch in San Salvador in Juni 1917: Zeitschr. Vulkanologie, Bd. 4, H. 2-3, pp. 193-200, 5 pls., June, 1918.

Gale, Hoyt S.

Borax in 1916. See Yale and Gale, no. 1083.

Magnesite in 1916. See Yale and Gale, no. 1084.

Galvez, Vicente.

324. Las aguas subterráneas al E. de Bahía Magdalena, Baja California: México, Inst. Geol., Anales, no. 3, pp. 7-31, 6 pls. (incl. maps), 1918.

3§5. Hidrología subterránea de los alrededores del pueblo de Tequesquipan y Hacienda de la Labor, Distrito de Temascaltepec, Estado de México: México, Inst. Geol., Anales, no. 3, pp. 33-52, 3 pls. (inct. map), 2 figs., 1918.

326. Estudio sobre la probabilidad de encontrar aguas subterráneas en el potrero de la Ciénega en el D. F.: México, Inst. Geol., Anales, no. 3, pp. 53-58, 3 pls. (incl. map), 1918.

Garfias, V. R.

327. Oil in southern Tamaulipas, Mexico (discussion) : Am. Inst. Min. Eng., Bull. no. 142, p. 1560, October, 1918.

Garfias, V. R., and Hawley, H. J.

328. Funnel and anticlinal-ring structure associated with igneous intrusions in the Mexican oil fields: Am. Inst. Min. Eng., Trans., vol. $5 \overline{7}, \mathrm{pp}$. 1071-1083, 3 figs. (with discussion, pp. 1083-1088), 1918.

Geijer, Per.

329. Den praktiska geologien i Nordamerika [economic geology in North America] : Geol. Fören. i Stockholm, Förhandl., Bd. 37, H. 3, pp. 193-214, March, 1915. 
George, H. C.

330. The Wisconsin zinc district: Am. Inst. Min. Eng., Trans., vol. 59, pp. 117-146, 30 figs. (with discussion pp. 146-150), 1918.

Gerry, C. N.

33.1. Gold, silver, copper, lead, and zinc in Idaho and Washington in 1916; mines report: U. S. Geol. Survey, Mineral Resources, 1916, pt. 1, pp. 565-616, March 14, 1918.

Gibson, Thomas $\mathrm{W}$.

332. Twenty-sixth annual report of the Ontario Bureau of Mines, 1917, being vol. XXVI. 366 pp., illus., maps, Toronto, 1917.

333. Statistical review of the mineral infistry of Ontario for 1917 : Ontario Bur. Mines, 27th Ann. Rept., 1918, pp. 1-77, Toronto, 1918.

Gilbert, Chester E., and Pogue, Joseph E.

334. The mineral industries of the United States; coal, the resource and its full utilization: U. S. Nat. Mus., Bull. 102, pt. 4, 26 pp., 1918.

335. Petroleum; a resource interpretation: U. S. Nat. Mus., Bull. 102, pt. 6, 74 pp., 3 pls., 12 figs., 1918.

Giles, Albert W.

336. The country about Camp Lee [near Petersburg], Virginia: Virginia, - Geor. Survey, Bull. no. 16, 40 pp., 16 pls. (incl. maps), 8 figs., 1918.

337. Eskers in the vicinity of Rochester, New York: Rochester Acad. Sci., Proc. vol. 5, pp. 161-240, 6 pls., 7 figs., July, 191. .

Gilmore, Charles W.

338. A newly mounted skeleton of the armored dinosaur, Stegosaurus stenops, in the United States National Museum: U. S. Nat. Mus., Proc. vol. 54, pp. 383-390, 7 pls., 1918.

Glenn, L. C.

339. Dr. A. H. Furdue: Tennessee State Geol. Sturvey, Resources of Tennessee, vol. 8, no. 1, pp. 3-6, January, 1918.

340. Discussion of the chemical analyses of the cave deposits of Tennessee: Tennessee State Geol. Survey, Resources of Tennessee, vol. 8, no. 2, pp. 139-142, April, 1918.

341. The Glenmary oil field: Tennessee State Geol. Survey, Resources of Tennessee, vol. 8, no. 3, pp. 211-219, Jnly, 1918.

Gooch, Stapleton D.

Vivianite from the land pebble phosphate deposits of Florida. See Watson and Gooch, no: 1007 .

Goodchild, W. H.

342. Magmatic ore deposits of Sudbury, Ontario: Econ. Geology, vol. 13, no. 2, pp. 137-143, March, 1918.

Gordon, C. H.

343. Barite deposits of the Sweetwater district, East Tennessee: Tennessee State Geol. Survey, Resources of Tennessee, vol. 8, no. 1, pp. 48-\$2, 5 figs., 1 pl. (map), January, 191.8.

344. Origin of the stylolitic structure in Tennessee marble (abstract): Science, new ser., vol. 47, p. 492, May 17, 1918.

345. On the nature and origin of the stylolitic structure in Tennessee marble: Jour. Geology, vol. 26, no. 6, pp. 561-568, 1 fig., September-October, 1918. 
Gordon, Samuel G.

346. Famous mineral localities; 3 , Amelia Court House, Virginia: Am. Mineralogist, vol. 3, no. 3, pp. 27-29, March, 1918.

Grabau, Amadeus W.

347. Relation of the oil-bearing to the oil-producing formations in the Paleozoic of North America (abstract) : Geol. Soc. America, Bull., vol. 29 , no. 1, pp. 92-93, March 31, 1918.

348. Significance of the Sherburne bar in the upper Devonic stratigraphy (abstract) : Geol. Soc. America, Bull., vol. 29, no. 1, pp. 127-128, March 31, 1918.

349. Isolation as a factor in the development of Paleozoic faunas (abstract) : Geol. Soc. America, Bull., vol. 29, no. 1, p. 143, March 31; 1918.

350. Conditions of deposition of marine salts and their bearing on the potash problem (abstract) : Science, new ser., vol. 47, p. 493, May $17,1918$.

351. The influence of the Ontario dome on the development of the Tertiary drainage of western New York, Ontario, and Michigan (abstract) : Science, new ser., vol. 47, pp. 493-494, May.17, 1918.

352. Geology of the Island of Gotland in the Baltic Sea (abstract) : New York Acad. Sci. Annals, vol. 27, pp. 272-273, November 30, 1917.

353. Stratigraphic relations of the oil-producing to the oil-bearing shales in Paleozoic of North America; involving a new theory of oil distributien (abstract): New York Acad. Sci., Annals; vol. 27, p. 298, November $30,1917$.

354. Problems of the interpretation of sedimentary rocks: Geol. Soc. America, Bull., vol. 28, no. 4, pp. 735-744, December 4, 1917.

355. Stratigraphic relationships of the Tully limestone and the Genesee shale in eastern North America: Geol. Soc. America, Bull., vol. 28, no. 4, pp. 945-958, 3 figs., December 19, 1917.

Grabau, Amadeus W., and O'Connell; Marjorie.

356. Were the graptolite shales, as a rule, deep or shallow water deposits?: Geol. Soc. America, Bull., vol. 28, no. 4, pp. 959-964, 1 fig., December $19,1917$.

Graham, R. P. D.

Contributions to the mineralogy of Black Lake area, Quebec. See Poitevin and Graham, no. 761.

See also Taber, no. 924.

Granger, Walter.

357. Notes on Paleocene and lower Eocene mammal horizons of northern New Mexico and southern Colorado: Am. Mus. Nat. Hist., Bull., vol. 37 , pp. $821-830,3$ pls., 1917.

358. New tillodont skull from the Huerfano Basin, Colorado (abstract): Geol. Soc. America, Bull., vol. 29, no. 1; pp. 147-148, March 31, 1918.

The skeleton of Diatryma, a gigantic bird from the lower Eocene of Wyoming. See Matthew and Granger, no. 648.

Fossil mammals of the Tiffany beds (abstract). See Matthew and Granger, no. 649 .

Granger, Walter; and Gregory, William $\mathrm{K}$.

359. A revision of the Eocene primates of the genus Northarctus: Am. Mus. Nat. Hist., Bull., vol. 37, pp. 841-859, 5. pls., 1917. 
Graton, L. C.

3\&o. The relation of sphalerite to other sulphides in ores (discussion) : $\mathbf{A m}$.

Inst. Min. Eng., Bull. no. 136, pp. 844-845, April, 1918.

361. Genesis of the Sudbury nickel-copper ores (discussion) : Am. Inst. Min.

Eng., Bull. no. 136, pp. 857-858, April, 1918.

See also Roberts and Longyear, no. 791 ; Teas, no. 936.

Graton, L. C., and McLaughlin, D: H.

362. Further remarks on the ores of Engels, California : Econ. Geology, vol. 13, no. 2, pp. 81-99, March, 1918.

Greene, F. C.

363. A contribution to the geology of eastern Osage County [Oklahoma]: Am. Assoc. Petroleum Geologists, Bull., vol. 2, pp. 118-123, 1918. :

Greenland, C. W.

364. The replacement of wood by calcite: Econ: Geology; vol. 18, no. 2, pp. 116-119, 2 pls., March, 1918.

\section{Greger, Darling $\mathrm{K}$.}

365. Invertebrate fauna of the Grassy Creek shale of Missouli (abstract) : Geol. Soc. America, Bull., vol. 29, no. 1, p. 95, March 31, 1918.

$\Delta$ msden formation of the east slope of the Wind River Mountains of Wyoming and its fauna. See Branson and Greger, no. 103.

Gregory, Herbert E.

366. Geology of the Navajo country; a reconnaissance of parts of Arizona, New Mexico, and Utah (U. S. Geol. Stirvey, Prof. Papel 93, 1917) : Abstract, by R. W. Stone, Washington Acad. Sci., Jour., vol. 8, no. 3, pp. 64-65, February 4, 1918.

367. A century of geology; Steps of progress in the interpretation of land forms: Am. Jour. Sci., 4th ser., vol. 46, pp. 104-1.32, July, 1.918. Reprinted in A century of science in America, pp. 122-152, New Haven, 1918.

Gregory, Herbert E., and others.

368. Military geology and topography; a presentation of certain phases of geology, geograplyy, and topography for military purposes. $281 \mathrm{pp.,}$ 117 figs. New Haven, Yale University Press, 1918.

Gregory, William K.

36.9. Second report of the committee on the nomenclature of the cranial elements in the Permian Tetrapoda; with appendices by $\mathrm{R}$. Broom, D. M. S. Watson, and, S. W. Williston: Geol. Soc. America, Bull. vol. 28 , no. 4, pp. 973-986, December 19, 1917.

A revision of the Eocene primates of the genus Notharctus. See Granger and Gregory, no. 359 .

Grenzig, J. A.

370. Developing crystallized mineral specimens: Am. Mineralogist, vol. 3, no.

7, p. 152, July, 1918.

Gress, E. M.

371. Critical study of fossil leaves from the Dakota sandstone (abstract):

Geol. Soc. America, Bull., vol. 29, no. 1; p. 131, March 31, 1918.

Griggs, Robert $\mathrm{F}$.

372. The Valley of Ten Thousand Smokes [Katmai district, Alaska]: Nat. Geog. Mag., vol. 33, no. 2, pp. 115-169, illus., February, 1918.

$122541^{\circ}-19-3$ 
Griggs, Robert F.-Continued.

373. The eruption of Katmai: Natare, vol. 101, pp. 497-499, 4 figs., August $22,1918$.

374. Are the Ten Thousand Smokes real volcanoes?: Ohio Jour. Sci., vol. 19, no. 2, pp. 97-116, 14 figs., Decenber, 1918.

375. The great hot mud flow of the Valley of Ten Thousand Smokes [Katmai, Alaska]: Ohio Jour. Sci., vol. 19, no. 2, pp. 117-142, 15 figs., December, 1918.

Grimes, J. A.

Ore deposits of the Boulder batholith of Montana. See Billingsley and Grimes, no. 73.

Grout, Trank F.

376. Genesis of the Sudbury nickel-copper ores (discussion) : Am. Inst. Min. Iing., Bull, no. 136, pp. 849-850, April, 1918.

377. The pegmatites of the Duluth gabbro: Econ. Geology, vol. 13, no. 3, pp. 185-197, 2 pls., 1 fig., May, 1918.

378. The lopolith; an igneous form exemplified by the Duluth gabbre: Am. Jour. Sci., 4th ser., vol. 46, pp. 516-522, 2 figs., September, 1918.

379. Internal structures of ignegus rocks (abstract, with discussion by W. J. Miller and M. E. Wilson ) : Geol. Soe. America, Bull., vol. 29, no. 1., pp. 100-101, March 31, 1918.

380. Internal structures of igneous rocks; their significance and : origin; with special reference to the Duluth gabbro: Jour. Geology, vol. 26, no. 5, pp. $439-458,9$ figs., July-August, $191 . \mathrm{S}$.

381. Two-phase convection in igneous magmas: Jour. Geolog pp. 481-499, 1 fig., September-October, 1.918. Alastract, Geol. Soc. America, Bull, vel. 2\%, wө. 1, pp. 101-102, March 31, 1918.

382. A type of igneous differentiation: Jour. Geology, vol. 26 , no. 7 , pp. 626658, 12 figs., October-November, 1918.

383. A form of multiple rock diagrams: Jour. Geology, rol. 26, no. 7, pl. 622-625, 3 figs., October-November, 1918.

See also Miller, no. 676; Roberts and Longyear, no. 791.

Gunter, H.

Geology between the Apalachicola and Ocklocknee rixers in Florida.

See Sellards and Gunter, no. 842.

Geology between the Choctawhatchee and Apalachicola rivers in Florida. See Sellards and Gunter, no. 843.

Haanel, Eugene.

384. Summary report of the Mines Branch of the Department of Mines fof Canada] for the calendar year ending December 31, 1917. $153 \mathrm{pp.}$ 4 figs., Ottawa, 1918.

Hager, Dorsey.

385. The search for new oil pools in the United States: Eng. and Min. Jour., vol. 105, pp. 11-12, 1. fig., January 5, 1918.

386. A few notes on the future work of the petroleum geologist in the MidContinent oil fields: Am. Inst. Min. Eng., Trans., vol. 57, pp. 891.$893,1918$.

387. Possible oil and gas fields in the Cretaceous beds of Alabama: Am. Inst. Min. Eng., Trans., vol. 59, pp. 424-431, 1 tig. (map) (discussion by E. DeGolyer and T. N. Ḱnapp, pp. 431-434), 1918; Bull. no. 194, pp. $469-476$, 1 fig., February, 1918; Bull. no. 136, pp. $819-\$ 22$ (discussion), April, 1918. 
Hager, Dorsey-Continued.

388. Geology of the oil fields of north central Texas: Am. Inst. Min. Eng., Bull. no. 138, pp. 1109-1118, S figs. (incl. sketch map), June, 1918. Discussion by W. E. Pratt, Bull. no. 140, pp. 1155-1156, August, 1918.

Hale, Fred A., Jr.

389. Ore deposits of the Yellow Pine mining district, Clark County, Nevada:

Am. Inst. Min. Eng., Trans., vol. 59, pp. 93-111, 2 figs., 1918; Bull. no. 134, pp. 535-553, 2 figs., February, 1918; Eng. and Min. Jour., vol. 105, pp. 455-460, 1. fig., March 9, 1918.

390. Manganese deposits of Clark County, Nevada: Eng. and Min. Jour., vol. 105, pp. 775-777, 3 tigs., April 27, 1918.

Haley, D. F.

391. Molybdenite operations at Climax, Colorado: Am. Inst. Min. Eng., Bull. no. 140, pp. 1183-1188, August, 1918.

Hamilton, Fletcher.

392. Magnesite, its occurrence and applications: Mineral Foote-Notes, vol. 2, no. 1, pp. 2-5, January, 1918.

Hamlin, Homer.

393. Earthquakes in southem California: Seismol. Soc. America, Bull., vol. 8, no. 1, pp. 20-24, March, 1918.

394. Aftershocks of the San Tacinto earthquake of April 21, 1918: Seismol. Soc. America, Bull., vol. \&, no. 4, pp. 131-134, December, 191.8.

Hancock, E. T.

395. Geology and oil and gas prospects of the Lake Basin field, Montana: U. S. Geol. Survey, Bull. 691, pp. 101-147, 8 pls. (incl. map), 1 fig., July 17, 1918.

Haney, Marshall.

396. Copper deposits of the Biue Ridge Mountains: Eng. and Min. Jour., vol. 106, pp. 248, August 10, 1918.

397. Manganese development in Virginia: Eng. and Min. Jour., vol. 1.06, p. 697 , October 19, 1918.

Hannibal, Harold.

398. Jura-Cretaceous stonewort and limneas, supposedly from Arkansas: Science, new ser., vol. 48, p. 57s, December 6, 1918.

Hard, Herbert A.

399. Road materials of North Dakota: North Dakota, Agr. Coll. Survey, 6th Bienn., Rept., pp. 29-37 [1913].

400. A system of eskers and kames in eastern Barnes County, North Dakota : North Dakota, Agr. Coll. Survey, 6th Bienn. Rept., pp. 39-43, 5 pls. [1913].

Harder, E. C.

401. Manganiferous iron ores of the Cuyuna district, Minnesota : Am. Inst. Min. Eng., l'rans., vol. 58, pp. 453-484, 4 figs. (with discussion, pp. 484-486), 1918.

Harder, E. C., and Johnston, A. W.

402. Notes on the geology and iron ores of the Cuyuna district, Minnesota (U. S. Geol. Survey, Bull. 661-A, 1917) : Abstract, by R. W. Stone, Washington Acad. Sci., Jour., vol. 8, no. 1, pp. 18-19, January 4, 1918: 
Harder, E. C., and Johnston, A. W.-Continued.

403. Preliminary report on the geology of east central Minnesota, including the Cuyuna iron-ore district: Minnesota Geol. Survey, Bull. no. 15, 178 pp., 22 pls. (incl. maps), 1918.

Harrington, George L.

404. Gold placers of the Anvik-Andreafski region, Alaska (U. S. Geol. Survey, Bull. 662-F, 1917) : Abstract, Washington Acad. Sci., Jour., vol. 8, no. 8, p. 248, April 19, 1918.

405. Late Tertiary and Quaternary history of the lower Yukon River region (abstract): Washington Acad. Sci., Jour., vol. 8, no. 12, p. 413, June 19, 1918.

Harris, G. D.

406. Age flow and ebb of the Eocene seas: Science, new ser., vol. 48, pp. 646647, December 27, 1918.

Hartmann, Miner Louis.

407. A bibliography of tungsten: South Dakota School of Mines, Bull. no. 12, pp. 160-255, September, 1918.

The occurrence; chemistry, metallurgy, and uses of tungsten, with special reference to the Black Hills of South Dakota. See Runner and Hartmann, no. 810.

Hastings, John B.

408. Ore deposits of the Boulder batholith of Montana (discussion): Am. Inst. Min. Eng., Bull. no. 133, pp. 72-75, January, 1918.

See also Spencer, no. 895 .

Hausman, Ieon Augustus.

409. An example of the possible intricacy of glacial modification of drainage within a narrow area: Am. Jour. Sci., 4th ser., vol. 45, pp. 153-173, 12 figs., March, 1918.

Hawkins, Alfred C.

410. Quartz crystals from Centerdale, Rhode Island: Am. Mineralogist, vol. 3, no. 1, pp. 1-2, January, 1918.

411. Fibrous quartz from Rhode Island: Am. Mineralogist, vol. 3, no. 7, Ip. 149-151, July, 1918.

412. Notes on the geology of Rhode Island: Am. Jour. Sci., 4th ser., vol. 46, pp. 437-472, 2 figs. (incl. map), August, 1918.

413. Minerals of the saline domes of the Texas-Louisiana Coastal Plain : Am. Mineralogist, vol. 3, no. 11, pp. 189-192, November, 1918.

Hawkins, A. C., and Wherry, E. T.

414. Famous mineral localities; 4, The Joplin district: Am. Mineralogist, vol. 3, no. 4, pp. 36-37, April, 1918.

Hawley, H. J.

415. Cretaceous and Tertiary stratigraphy of the western end of the Santa Ynez Mountains, Santa Barbara County, California (abstract) : Geol. Soc. Ámerica, Bull., vol. 29, no. 1, p. 164, March 31, 1918. Funnel and anticlinal-ring structure associated with igneous intrusions in the Mexican oil fields. See Garfias and Hawley, no. 328.

Haworth, Erasmus.

416. Historical outline of the oil and gas industry in Kansas: Kansas Geol. Survey, Bull. 3, pp. 19-24, 1917. 
Hay, Oliver P.

417. [Report of work on Pleistocene Vertebrata] : Carnegie Inst. Washington, Year Book no. 16, 1917, pp. 331-332, 1918.

418. Further considerations of the occurrence of human remains in the Pleistocene deposits at Vero, Florida: Am. Anthropologist, new ser., vol. 20, no. 1, pp. 1-36, 1 fig., January-March, 1918.

419. A review of some papers on fossil man at Vero, Florida: Science, new ser., vol. 47, pp. 370-371, April 12, 1918.

420. Doctor Aleš Hrdlička and the Vero [Floridal man: Science, new ser., vol. 48 ; pp. 459-462; November 8, 1918.

Hayes, C. Willard, Vaughan, T. Wayland, and Spencer, Arthur C.

421. Geology. of. Cuba; a reprint of the chapters on physiography and general geology from the "Report on a geological reconnaissance of Cuba," partly revised by Pablo Ortega: Cubá, Dirección de Montes y Minas, 37 pp., 2 figs.; 2 pls. (incl. geol. map by Manuel Fernandez de Castro and Pedro Salterain y Legarra), Habana, 1918.

Haynes, Winthiop P.

Oil and gas resources of Kansas. "See Moore and Haynes, no. 697.

Hayward, M. W.

Molybdenum mining at Climax, Colorado. See Brown and Hayward, no. 109.

Fazard, D. L.

422. The relation between seismic and magnetic disturbances: Seismol. Soc. America, Bull., vol. 8, no. 4, pp. 117-124, December, 1918.

Heald, K. C.

423. Structure and oil and gas resources of the Osage Reservation, Oklahoma ; T. 27 N., R. 7 E.: U. S. Geol. Survey, Bull. 686, pp. 129-135, 1 pl. (map), 2 figs., 1918.

424. Geologic structure of the northwestern part of the Pawhuska quadrangle, Oklahoma: U. S. Geol. Survey, Bull. 691, pp. 57-100, 3 pis., 11 figs., February 7, 1918 . Abstract, by R. W. Stone, Washington Acad Sci., Jour., vol. 8, no. 8, p. 249, April 19, 1918.

Structure and oil and gas resources of the Osage Reservation, Oklahoma. See Winchester and others, no. 1067.

Heald, K. C., and Mather, Kirtley F.

425. Structure and oil and gas resources of the Osage Reservation, Oklahoma; Tps. 24 and 25 N., R. 8 E.: U. S. Geol. Survey, Bull. 686, pp. 149170, 3 pls. (incl. maps), 2 figs., 1918.

Heikes; V. C.

426. Gold, silver, copper, lead, and zinc in Utah in 1916; mines report: U. S. Geol. Survey, Mineral Resources, 1916, pt. 1, pp. 421-455, January $24,1918$.

427. Gold, silver, copper, leid, and zinc in Nevada in 1916 ; mines report: U. S. Geol. Survey, Mineral Resources, 1916, pt. 1, pp. 457-500, January 19, 1918.

Henderson, Charles W.

428. Gold, silver, copper, lead, and zinc in Colorado in 1916; mines report. U. S. Geol. Suryey, Mineral Resources, 1916, pt. 1., pp. 331-388. February 5, 1918. 
Henderson, Junius.

429. The nomenclature and systematic position of some North American fossil and recent molfusks: The Nautilus, vol. 32 , no. 2, pp. 60-64, October, 1918.

Hershey, Oscar H.

430. Geology of the Success mine [Coeur d'Alene district, Idaho] : Min. and Sci. Press, vøl. 116, p. 470, April 6, 1918.

Hewett, D. F.

431. Manganese and manganiferous ores in 1916: U. S. Geol. Survey, Mineràl Resources, 1916, pt. 1, pp. 731-756, 1 fig., July 18, 1918.

Hewett, D. F., and Lupton, C. T.

432. Anticlines in the sonthern part of the Big Horn Basin, Wyoming (U. S. Geol. Survey, Bull. 656, 1917): Abstract, by R. W: Stone, Washington Acad. Sci., Jour., vol. \&, no. 7, pp. 204-205, April 4, 1918.

Hewett, D. F., Stose, G. W., Katz, F.. 3., and Miser, H. D.

433. Possibilities for manganese ore on certain undeveloped tracts in Shenandoah Valley, Virginia: U. S. Geol. Survey, Bull. 660, pp. 271296, 8 figs. (incl. maps), January 21, 1918. Abstract, by R. W. Stone, Washington Acad. Sci., rol. 8, no. 13, p. 450, July 19, 1918.

Hill, James $\dot{M}$.

434. Bauxite and aluminum in 1917 : U. S. Geol. Survey, Mineral Resources, 1917, pt. 1, pp. 1-9, .June 21, 1918.

435. Platinum and allied metals in 1917 : U. :S. Geol. Survey, Mineral Resources, 1917, pt. 1, pp. 11-21, June 21, 191.8.

436. Gold, silver, copper, lead, and zinc, in the eastern States in 1917: U. S. Geol. Survey, Mineral Resources, 1917, pt. 1, pp. 55-62, July 29, 1918.

437. Strontium in 1917 : U. S. Geol. Surwey, Mineral Resources, 1917, pt. 2, pp. 5-6, June 19, 1918.

438. Barytes and barium products in 1917: U. S. Geol. Survey; Mineral Resources, 1917, pt. 2, pp. 285-291, October 14, 1918.

Hinds, Henry.

439. The geology and coal resources of Buchanan County, Virginia : Virginia Geol. Survey; Bull. no. 18, pp. 1-250, 9 pls. (incl. maps), 22 figs., 1918.

Hintze, F. F.

440. Age of the Martinsburg shale as interpreted from its structural and stratigraphical relations in eastern Pennsylvania (abstract) : Geol. Soc. America Bull., vol. 29, no. 1, pp. 94-95, March 31, 1918.

Hoadley, Charles W.

441. An American occurrence of cronstedtite [Long Hill, Trumbull Township, Connecticut] : Am. Mineralogist, vol. 3, no. 1, p. 6, January, 1918 .

Hobbs, William Herbert.

442. The erosional and degradational processes of deserts, with especial reference to the origin of desert depressions: Assoc. Am. Geographers, Annals, vol. 7, pp. 25-60, 13 pls., 9 figs., '[1918].

Hodge, E. T.

443. Geology of the Coamo-Guayama region, Porto Rico (abstract) : New

York Acad. Sci., Annals, vol. 27, pp. 277-278, November 30, 1917. 
Holden, Edwird F.

444. Tanons mineral qocalities: Beryl MInntan, Acworth, New Hampshire: Am. Mineralogist, vo1. 3, no. 12, pp. 199-200, Decenber, 1918.

Holland, L. F. S.

445. Recent derelopments in molybdenum [CClimax, Stomniit :County, Coloradol. Min. and Sci. Press, vol. 117, 191. 529-531, 2 figs., October $1.9,1918$.

Frolmes, W. H.

446. On the antigrity of man in Anelica: :Science, new ser., rol. 47, pp. 561562 , June 7 , 1918 .

Holtedahl, Olaf.

447. Summaty of geological results: Second Norwegian Arctic Experlition in the Fram, 1898-1902, Rept., no. 36, 27 pp., 6 pls., 4 figs., man, 1917. [Not seen.]

Honess, Arthur P.

448. On the etching figures of the dihexagonal alternating type: Am. Jour. Sci., 4th sel:., vol. 45, pp. 201-221, 18 figs., March, 1918.

Fopkins, Cyril G., and :others.

449. McLem Comnty soils: Hilinois, Uniw., Agr. Exp. Sta., Soil Rept. no. 10, 52 pp., 8 figs., maps, May, 1915.

450. Champaign County soils: Illinois, Univ. Agr. Exp. Sta., Soil Rept. no. 18, 61 pp., 14 tigs., maps, November, 1918.

Hopkins, L. L.

451. Sand; its occurrence, properties, and uses; a bibliography : Carnegie Library of Pittsburgh, 72 pp., Pittsburgh, 1918.

Hopkins, Oliver B.

452. The Palestine salt dome, Anderson County, Texas; The Brenham salt dome, Washington and Austin counties, Texas (U. S. Geol. Survey, Bull. 661-G, 1917) : Abstract, by R. W. Stone, Washington Acud. 'Sci., Jour., vol. 8, no. 6, p. 173, March 19, 1918.

453. Oil and gas possibilities of the Hatchetigbee anticline, Alabama (U. S. Geol. :Survey, Bull. 661-H, 1917) : Abstract, by R. W. Stone, Washington Acad. Sci., Jour., vol. 8, no. 6, pp. 173-174, March 19, 1918.

454. Structure and oil and gas resources of the Osage Reservation, Oklahoma; T. 25 N., R. 11 and 12 E.: U. S. Geol. Survey, Bull 686, pp. 75-90, 2 pls. (incl. mapl), 2 figs.; 1918.

The De Soto-Red River oil and gas field, Louisianil. See Matson and Hopkins, no. 631 .

The Corsicana oil and gas field, Texas. See Matson and Hopisins, no. 632.

Hopkins, Percy E.

455. The Kowkash gold area (second report): Ontario Bur. Mines, 26th A:ın. Rept., 1917, vol. 26, pp. 190-226, illus., map, 1917.

456. A recent discovery in northern Ontario [gold, Rickard Towaship] : Cauatdian Min. Jour., vol. 39, no. 4, pp. 56-58, 4 figs., February 15, 1918.

457. Ogahalla to Collins on the National Transcontinental Railway, (Mntario: Ontario Bur. Mines, 27th Ann. Rept., 1918, p1. 187-1:19, 1 pl. (map), 11 figs. (incl. maps), 1918.

458. Notes on Lake Abitilyi area : Ontario Bur. Mines, 27th Amn. Rept., 1918, pp. 200-214, 12 figs. (incl. maps), 1918. 
Hoskin, Arthur J.

459:- The oil' shale industry [northwestern Colorado]: Min. and Sci. Press; vol. 116, pp. 509-516, 5 figs., April 13, 1918.

Hostetter, J. C.

Zonal growth in hematite and its bearing on the origin of certain iron ores. See Sosman and Hostetter, ńo. 891.

Hovcy, Edmund Otis.

460. Proceedings of the thirtieth annual meeting of the Geological Society of America, held at Saint Louis, Missouri, December 27, 28, and 29, 1917: Geol. Soc. America, Bull., vol. 29, no. 1, pp. 1-118, 8 pls., March 31, 1918.

461. Notes on the geology of the region of Parker Snow Bay, Greenland (abstract) : Geol. Soc. America, Bull., vol. 29, no. 1, p. 98, March 31, 1918.

See also Lkblaw, no. 278.

Howe, Marshall A.

462. Contributions to the geology and paleontology of the Canal Zone, Panama, and geologically related areas in central America and the West Indies; on some fossil and recent Lithothamnieae of the Panama Canal Zone: U. S. Nat. Mus., Bull. 103, pp. 1-13, 11 pls., 1918.

Hubbard, Bela.

The limonite deposits of Mayaguez Mesa, Porto Rico. See Fettke and Hubbard, no. 310.

Hubbard, George D.

463. Possible local glaciation in southern Vermont (abstract) : Assoc. Am. Geographers, Annals, vol. 7, p. 77 [1918].

Hudson, George $\mathrm{H}$.

464. The interesting geological features at the Champlain Assembly, Cliff Haven, N. Y.: New York State Mus. Bull. 196, pp. 149-160, 6 pls., April 1, 1917 [1918].

465. Some structural features of a fossil embryo crinoid: New York State Mus. Bull. no. 196, pp. 161-163, 1 pl., April 1, 1917 [1918].

Hugienin, Emile. See Bradley and others, no. 100.

Hull, J: P. D.

A preliminary report on a part of the pyrites deposits of Georgia. See Shearer and Hull, no. 859.

Huntington, Ellsworth.

466. Climate and the evolution of civilization. In The evolution of the earth and its inhabitants [edited by R. S. Lull], pp. 147-193, 8 figs., New Haven, Yale University Press, 1918.

Iddings, Joseph $\mathrm{P}$.

467. Memorial of Arnold Hague: Geol. Soc. America, Bull., vol. 29, no. 1, jp. 35-48, port., March 31, 1918.

Jackson, Robert Tracy.

468. Contributions to the geology and paleontology of the Canal Zone, Panama, and geologically related areas in Central America and the West Indies; Fossil Echini of the Panama Canal Zone and Costa Rica: U. S. Nat. Mus., Bull. 103, pp. 103-116, 7 pls., 3 figs.; 1918. 
Jaggar, T. A.

469. Results of volcano study in Hawaii : Nature, vol. 101, pp. 54-57,.4 figs., March 21, 1918.

Jaggar, T. A., and Romberg, Arnold.

470. An experiment in teleseismic registration: Seismol. Soc. America, Bull.," vol. S, nos. 2-3, pp. 8S-89, 1 pl., June-September, 1918.

Janin, Charles.

471. Gold dredging in the United States: U. S. Bur. Mines, Bull. 127, 226 pp., 63 pls., 23 figs., 1918.

Jefferson, Mark.

472. Some considerations on the geographical provinces of the United States: Assoc. Am. Geographer's, Annals, vol. 7, pp. 3-15, 2 pls.

Jenkins, Olaf $P$.

473. 'Two manganese deposits in northern Washington : Eng. and Min. Jour., vol. 105 , p. 1082, June 15, 1918:

474. Notes on the possible origin of the magnesite near Valley, Washington: Econ. Geology, vol. 13, no. 5, pp. 381-384, 2 pls., 2 figs., July, 1918.

475. Spotted lakes of epsomite in Washington and British Columbia: Am. Jour. Sci., 4th ser., vol. 46, pp. 638-644, 5 figs., November, 1918.

Jennings, Otto E.

476. Rieport on a collection of Oligocene plant fossils from Montana (abtract) : Geol. Soc. America, Bull., vol. 29, no. 1, p. 147, March $31,1918$.

Johansen, Albert.

477. Petrological abstracts and reviews: Jour. Geology, vol. 26, no. 1, pp. 82-88; no. 2 , pp. $186-189$; no. 3 , pp. $272-282$; no. 4, pp. 377-381; no. 5 , pp. $471-477,1918$.

Johnson, Bertrand L.

378. Chalmersite, $\mathrm{CuFe}_{2} \mathrm{~S}_{3}$, a new ore of copper (abstract) : Washington Acad. Sci., Jour., vol. 8, no. 4, pp. 99, February 19, 1918.

479. The Valdez delta [Alaska] (abstract): Washington Acad. Sci., Jour., vol. \&; no. 12, pp. 410-411, June 19, 1918.

Johnson, Douglas Wilson.

480. Block faulting in the Klamath Lakes region [Oregon] : Jour. Geology, vol. 26, no. 3, pp. 229-236, 5 figs., April-May, 1918.

Johnson, Roswell H.

481. The distribution of underground salt water and its relation to the accumulation of oil and gas: Am. Assoc. Petroleum Geologists, Bull., vol. 2 , pp. 172-176, 1918.

482. Cause of the absence of water in dry sandstone beds (abstract) : Geol. Soc. America, Bull., vol. 29, no. 1, p. 105, March 31, 1.918.

Johnston, A. W.

Notes on the geology and iron ores of the Cuyuna district, Minnesota. See Harder and Johnston, no. 402.

Preliminary report on the geology of east central Minnesota, including the Cuyuna iron-ore district. See Harder and Johnston, no. 403.

Johnston, W. A.

483. Reconnaissance soil survey of the area along the Hudson Bay Railway: Canada, Geol. Survey, Summ. Rept. 1917, pt. D, pp. 25-36, 1918. 
Johnston, W. A.-Continued.

484. Semirefractory chy and pure quartz sand of Swan River valley MManitoba ] : Canada, Geol. Survey, Summ. Rept. 1917, pt. D, pp. 37-39, 1918.

Jonas, Anna I.

485. Pre-Cambrian and Triassic diabase in eastern Pennsylvania: Am. Mus. Nat. Hist., Bull., vol. 37, pp. 173-181, map, 1917. Abstract, New York Acad. Sci., Annals, vol. 27, p1. 297-298, Novenber 30, 1917.

Jones, E. L., jr.

486. Manganese in the Colorado River desert region: Min. and Sci. Press, vol. 117 , pp. 755-758, 5 figs., December 7, 1918.

Jones, J. C.

487. Note on the occurrence of a mammalian jaw, presumably from the Truckee beds of western Nerada (abstract): Geol. Soc. America, Bull., vol. 29, no. 1, p. 161, March 31, 1918.

Jones, Robert $W$.

488. The manganese deposits of Sotth Wallingford, Vernont: Eng. and Mir. Jour., vol. 105, p. 779, Apriil 27, 1918.

Jones, William F.

489. Discussion of paper by A. W. Laver, "The petrology of reservoir rocks and its influence on the accumulation of petroleum "; Econ. Geology, vol. 13, no. 2, pp. 147-149, March, 1918.

490. A geological reconnaissance in Haiti ; a contribution to Antillean geology : Jour. Geology, vol. 26, no. 8, pp. 728-752, 1 pl., 10 tigs., November-December, 1918.

491. Intrusive origin of the Gulf coast salt domes; its bearing on the accumulation of oil (discussion): Econ. Geology, vol. 13, no. 8, pp. 621-622, December', 1918.

Katz, Frank J.

492. Late Pleistocene shore line in Maine and New Hampshire (abstract): Geol. Soc. America, Bull., vol. 29, no. 1, p. 74, March 31, 1918.

493. Pleistocene shore lines in Maine and New Hampshire (abstract) : Washington Acad. Sci., Jour. vol. 8, no. 12, p. 410, June 19, 1918.

494. Feldspar in 1917: U. S. Geol. Survey, Mineral Resonrces, 1917, pt. 2, pp. 139-144, 1 fig., August 7, 1918.

495. Silica in 1917 : U. S. Geol. Survey, Mineral Resources, 1917, pt. 2, pp. 207-211, September 13, 1918.

496. Abrasive materials in 1917: U. S. Geol. Surrey, Mineral Resources, 1917, pt. 2, pp. 213-232, September 24, 1918.

Possibilities for manganese ore on certain undereloped tracts in Shenandoah Valley, Virginia. See Hewett and others, no. 433.

Kay, George F.

497. Pleistocene deposits between Manilla, in Crawford County, and Coon Rapids, in Carroll County, Towa (abstract, with discussion by Frank Leverett, J. L. Rich, and T. 12. Todd) : Geol. Soc. America, Bull. vol. 29, no. 1; pp. 77-79, March 31, 1918.

Keele, Joseph.

498. Investigation of clay and shale resources: Canada, Dept. Mines, Mines Branch, Summ. Rept. 1917, pp. 97-111, 1918. 
Keith, Arthur, and Sterrett, D. B.

499. Tin resources of the Kings Mountain district, North Carolina and South Carolina (U. S. Geol. Survey, Bull. 660-D, 1917) : Abstract, by R. W. Stone, Washington A.cad. Sci., Tour., vol. 8, no. 5, p. 129, March 4, 1918.

Kellogg, Remington.

500. Pinnipeds from Miocene and Pleistocene deposits of California (abstract): Geol. Soc. America, Bull., vol. 29, no. 1, p. 161., March $31,1918$.

Kemp, James F.

501. John Duer Irving: Eng. and Min. Jour., vol. 106, pp. 260-263, port., August 10, 1918.

502. John Duer Irving.: Science, new ser., vol. 48, pp. 255-256, Saptember $13,1918$.

Kemp, J. F., and Billingsley, Paul.

503. Notes on Gold Hill and vicinity, Tooele County, western Utall: licon. Geology, vol. 13, no. 4, pp. 247-274, 5 pls. (incl. map), 9 figs.. June, 1918.

Kempher, L. S.

504. Remarks on the geology of the nortb-central Texas oil and gas rexion: 22 pp., Fort Worth, Texas, 1918. [Priv, pul., J. E. Head \& Co.]

'Kennedy, William.

505. Principles and problems of oil prospecting in the Gulf coast country (discussion) : Am. Inst. Min. Eng., Bull. no. 139, pp. 1145-1146, July, 1918 .

See also Matteson, no. 634.

Keyes, Charles R.

506. Rate of desert delta growth: Science, new ser., vol. 47, pp. 193-1.94, February 22, 1918.

507. Mechanics of laccolithic intrusion (abstiact): Geol. Soc. America, Bull., vol. 29, no. 1, p. 75, March 31, 1918.

508. Faceted forn of a collapsing geoid (abstract) : Geol. Soc. America, Bull., vol. 29, no. 1, p. 76, March 31, 1918.

509. Diverse ancestry of Great Basin lakes (abstract) : Science, new ser., vol. 47 , pp. $469-470$, May 1.0, 1.918.

510. Lacustral record of past climates: Monthly Weather Rev., rol. 46, pp. 277-280, June, 1918 .

511. Formative setting of laccolithic mountains: Science, new ser., vol. 48 , pp. 138-139, August 9, 1918.

512. Geologic structure of Sierra del Oro in New Mexico: Fng. and Min. Jour., vol. 106, pp. 494-495, September 14, 1918.

513. Introduction of the new geology into Americi: Johns Hopkins Alumini Mag., vol. 7, no. 1, pp. 15-22, November:, 1918.

Kew, W. S. W.

514. Geologic range and evolution of the more important Pacific coast echinoids (abstract): Geol. Soc.' America, Bull., vol. 29, no. 1, p. 164, March 31, 1918.

Kindle, E. M.

515. Notes on sedimentation in the Mackengie River basin: Tour. Geology, vol. 26, no. 4, pp. 341-360, 13 figs., May-June, 1918. 
Kindle, E. M.-Continued.

516. Separation of salt from saline water and mud: Geol. Soc. America, Buli., vol. 29, no. 1, p. 80 (abstract), March 31, no. 3, pp. 471-487, 12 figs., September 30, 1918.

517. An Ottawa beach of the Champlain sea: Ottawa Naturalist, vol. 32 , no. 5, pp. 83-86, 2 figs., November, 1918.

518. Diagnostic characteristics of marine clastics: Geol. Soc. America, Bull. vol. 28 , no. 4; pp. 905-916, 10 figs., December 14, 1917.

Kirk, Edwin.

519. Stratigraphy of the Inyo Range [southern California] : U. S. Geol: Survey, Prof. Paper 110, pp. 19-49, 1918.

520. An Ordovician fauna from southeastern Alaska (abstract) : Geol. Soc. America, Bul1., vol. 29, no. 1, pp. 143-144, March 31, 1918.

521. Paleozoic glaciation in southeastern Alaska: Am. Jour. Sci., 4th ser., vol. 46, pp. 511-515, Sentember, 191.8. Abstract, Geol. Soc. America, Bull., vol. 29, no. 1, pp. 149-151, March 31, 1918:

Kithil, Karl L., and Davis, John A.

522. Mining and concentration of cainotite ores: U. S. Bur. Mines, Bull. 103, 89 pp., 14 pls., 5 figs. 1917.

Klotz, Otto.

523. Analysis of earthquake wares: Seismol. Soc. America, Bull., vol. 8, nos. 2-3, pp. 83-87, 1 fig., June-September, 191.8.

524. The transmission of earthquake waves: Roy. Soc. Canada, Trans., ser. 3, vol. 12, sec. 3, pp. 37-41, June and September, 1918.

Knapp, I. N.

525. Gas sands: Natural Gas Assoc. America, Proc., vol. 6, pp. 41-57, 13 figs. [1914].

Knight, Cyril $\mathrm{W}$.

Euxenite, a radioactive mineral in South Sherbrooke Township, Lanark County. See Miller and Knight, no. 674.

Knight, S. H.

526. Climatic conditions in southern Wyoming during deposition of the "red beds" (abstract): New York Acad. Sci., Annals, vol. 27, pp. 255-256, November 30, 1917.

Knopf, Adolph.

527. A geologic reconnaissance of the Inyo Range and the eastern slope of the southern Sierra Nevala, California; with a section on The stratigraphy of the Inyo Range, by Edwin Kirk: U. S. Geol. Survey, Prof. Paper 110, 130 pp., 23 pls. (incl. maps), 8 figs., 1918.

528. Geology and ore deposits of the Yerington district, Nevada: U. S. Geol.

Survey, Prof. Paper 114, 68 pp., 5 pls. (incl. map), 12 figs., 1918.

529. The antimonial silver-lead veins of the Arabia district, Nevada: U. S. Geol. Survey, Bull. 660, pp. 249-255, January 7, 1918.

530. Strontianite deposits near Barstow, California: U. S. Geol. Survey, Bull. 660 , pp. 257-270, 1 pl. (map), January 18, 1918. Abstract, Washington Acad. ,Sci., Jour., vol. 8, no. 4, pp. 94-95, February $19,1918$.

531. Economic geology [in 1917] : Eng. and Min. Jour., vol. 105, pp. 105-107, January $12,1918$.

532. Tin in 1916: U. S. Geol. Survey, Mineral Resources, 1916; pt. 1, pp. 617-622, liebruary 6, 1918. 
Knopf, Adolph-Continued.

533. Tin in 1917: U. S. Geol. Survey, Mineral Resources 1917, pt. 1, pp. 63-72, 1 pl., 1 fig., September 16, 1918.

534. Occurrence of the silver halides in the oxidized zone of ore deposits (discussion) : Econ. Geology, vol. 13, no. 8, pp. 622-624, December, 1918.

Knowlton, F. H.

535. Fossil floras of the Vermejo and Raton formations of Colorado and New Mexico: U. S. Geol. Survey, Prof. Paper 1.01, pp. 223-435; $\$ 4$ pls., 1917.

Kraus, E. H., and Peck, Albert B.

536. Some new thermo-optical observations on gypsum and glauberite: Michigan Acad. Sci., 19th Ann. Rept., pp. 95-100, 3 pls., 1917.

Kưmmel, Henry B.

537. Report of the State geologist: New Jersey, Dept. Conservation, Ann. Rept. 1917, pp. 23-50, 1918.

Kuhre, K. D.

538. Tungstenite, a new mineral in the Cottonwoods, Utah: Salt Lake Min: Rev., vol. 19, no. 18, pp. 23-24, 1 fig., December 30, 1917.

Kunz, George Frederick.

539. Remarks on a pseudo-meteorite, iron pyrite crystals, and a black diamond (abstract) : New York Acad. Sci., Annals, vol. 27, pp. 271272 , November $30,1917$.

540. Biographical sketch of the late L. P. Gratacap: Am. Mus. Jour., vol. 18, no. 4, pp. 302-304, port. (p. 298), April, 1918 .

541. Genesis of the Sudbury nickel-copper ores (discussion foccurrence of palladium and platinum] ) : Am. Inst. Min. Eng., Bull. no. 136, pp. 848-849, April, .1918.

See also Robert and Longyear, no. 7.91.

Lacroix, A.

542. L'eruption du volcan de Quetzaltepeque et le tremblement de terre destructeur de San Salvador (juin-juillet 1917) : Acad. Sci., Paris, Compt. Rend., t. 165, no. 27, pp. 1077-1082, December 31, 1917.

Lambe, Lawrence $M$.

543. On the genus Trachodon of Leidy : Ottawa Naturalist, vol. 31, no. 11, pp. 135-139, February, 1918:

544. On the remains of a selachian from the Edmonton Cretaceous of Alberta : Ottawa Naturalist, vol. 32, no. 2, pp. 27-28, 1 fig., May, 1918.

545. The Cretaceous genus Stegoceras, typifying a new family referred provisionally to the Stegosauria: Roy. Soc. Canada, Trans., ser. 3, vol. 12, sec. 4, pp. 23-36, 2 pls., 1 tig., June and September, 1918.

Lane, Alfred C.

546. Prismatic cleavage in beryl: Am. Mineralogist, vol. 3, no. 5, p. 47, May, 1918.

547. Israel Cook Russell (1852-1906) : Am. Acad. Arts and Sci., Proc. vol. 53 no. 10, pp. 855-853, September, 1918.

Laney, Francis B.

The genesis of the ores at Tonopah, Nevada. See Bastin and Laney, no. 51 . 
Larsen, Esper S.

548. The probable identity of mazapilite with arseniosiderite: Am. Mineralogist, vol. 3, no. 2, pp. 12-14, February, 1918.

Ledoux, A.

549. Tourmaline from Macdonald Island, Baffin Land: Ottawa Naturalist, vol. 32, no. 3, pp. 49-51, 1 fig., September, 1918.

Ledoux, A., and Walker, T. L.

550. Cerusite from Salmo, British Columbia: Ottawa Naturalist, rol. 32, no. 1, pp. 7-8, April, 1918.

Lee, Howard S.

551. Pyrite deposits of Leadville, Colorado: Am. Inst. Min. Eng., Bull. no. 140, pp. 1223-1228, August, 191.8. Abstract, Eng. and Min. Tour., vol. 106, pp. 384-385, August 31, 1918.

Iee, Wallace.

552. Geology of the Kentucky part of the Shawneetown quadrangle: Kentucky Geol. Survey, 73 pp., map, 1916.

Lee, Willis T.

553. The geologic story of the Rocky Mountain National Park, Colorado: U. S. National Park Service, 89 pp., 45. pls. (incl. maps), 6 figs, 1917.

554. Geology of the Raton Mesa and other regions in Colorado and New Mexico: U. S. Geol. Survey, Prof. Paper 101, pp. 9-221, 29 pls. (incl. map), 16 figs., 1917. Abstract, by R. W. Stone, Washington Acạd. Sci., Jour., vol. 8, no. 13, pp. 451-452, July 19, 1918.

555. Application of physiographic methods to the correlation of non-malline formations in the Rocky Mountains (abstract) : New York Acad. Sci., Annals, vol. 27, pp. 266-267, November 30, 1917.

556. Early Mesozoic physiography of the southern Rocky Mountains: Smithsonian Misc. Coll., vol. 69, no. 4, 41 pp., 4 pls., 6 figs., July, 1918.

Lees, J. H. See Tomlinson, no, 950 .

Lees, James H., and Alden, William C.

557. The country around Camp Dodge. [Text on back of topographic map], Iowa, Camp Dodge quadrangle, U. S. Geol. Survey, 1918.

Leighton, Henry.

558. Pyrite in the coals of western Pennsylvania (abstract): Science, new ser., vol. 47 , p. 494, May $17,1918$.

Leighton, Morris M.

559. The country about Camp Lewis [Washington]: Washington Geol. Survey, Bull. no. 18, 105 pp., 12 pls., 6 tigs., 1918.

Leith, C. $\mathbf{K}$.

560. "War minerals" as a science: Econ. Geology, vol. 13, no. 7, pp. 497-499, November, 1918.

561. International control of minerals: U. S. Geol. Survey, Mineral Resources, 1917, pt. 1, pp. 7a-16a, December 31, 1918.

Lenher, Victor.

562. Further studies on the deposition of gold in nature: Econ. Geology, vol. 13, no. 3, pp. 161-184, 4 pls., 1. fig., May, 1918. 
Lesher, C. E.

563. Coal in 1916: U. S. Geol. Survey, Mineral Resources, 1916, pt. 2, pp. 901-991, August 17, 1918.

Leverett, Frank.

564. Early stages and outlets of Lake Agassiz: North Dakota, Agr. Colf. Survey, 6th Bien. Rept., pp. 17-28, 4 pls. (incl. map) [1913].

565. Surface geology and agricultural conditions of Michigan: Michigan Geol. Survey, Pub. 25 (geol. ser. 21), 223 pp., 15 pls. (incl. map), 25 figs:, 1917.

566. Glacial lakes and their correlative ice borders in the Superior basin (abstract) : Michigan Acad. Sci., 19th Ann. Rept., pp. 101-102, 1917 .

567. The country around Camp Custer [Michigan] : [Text on back of topographic map], Michigan, Camp Custer quadrangle, U. S. Ceol. Survey, 1918.

568. Glacial lakes of Saginaw basin in relation to uplift (abstract) : Geol. Soc. America, Bull., vol. 29, во. 1, p. 75, March 31, 1918.

See also Fairchild, no. 297 ; Kay, no. 497 ; Tomlinson, no. 950.

Levison, Wallace Goold.

569. Notes on gageite from Franklin Furnace, New Jersey: Am. Mineralogist, vol. 3 , no. 7, p. 153, July, 1.918.

Lewis, James 0 .

570. Petrology of reservoir rocks (discussion) : Econ. Geology, vol. 13, no. 1, pp. 65-69; January, 1918.

Lindgren, Waldemar.

571. Genesis of the Sudbury nickel-copper ores (discussion): Am. Inst. Min. Eng., Bull. no. 136, p. 857, April, 1918.

572. The occurrence of the halogen salts of silver: Econ. Geology, vol. 13, no. 3, pp. 225-226, May, 1918 .

573. John Duer Irving: Eng. and Min. Jour., vol. 106, pp. 263-264, August $10,1918$.

574. John Duer Irving: Econ. Geology, vol. 13, no. 6, pp. 413-418, port., September, 1918.

575. The Idaho peneplain (discussion): Econ. Geology, vol. 13, no. 6, pp. 486-488, September, 1918.

576. Volume changes in metamorphism: Jour. Geology, vol. 26, no. 6, pl. 542-554, September-October, 1918

See also Roberts and Longyear, no. 791.

Iittle, Homer P.

577. Development of knowledge concerning the physical features of Anne Arundel County, with bibliography; the physiography . . .; the geology . . .; the mineral resources .... Maryland Geol. Survey, Anne Arundel County, pp. 23-132, 6 pls., maps, 1917.

Livingston, D. C.

578. The Idaho peneplain (discussion): Econ. Geology, vol. 13, no. 6, np. 4S8-492, 1. pl. (relief map), September, 1918.

Lloyd, E. Russell, and Mather, Kirtley F.

579. Structure and oil and gas resources of the Osage Reservation, Oklahoma; T. 20 N., R. 11 E.: U. S. Geol. Survey, Bull. 686, pp. 119127,2 pls. (incl. map), 1. fig., 1918: 
Lobeck, A. K.

580. The superb position of New: York City as a center for physiographic study: New York Acad. Sci., Annals, vol. 28, pp. 1-50, 29 figs., June 29, 1918.

Loel, W. F.

581. Vaqueros formation in California (abstract) : Geol. Soc. America, Bull., vol. 29, no. 1, p. 165, March 31, 1918.

Logan, C. A. See Bradley and others, no. 100.

Logan, William $\mathrm{N}$.

582. The Mount Carmel fault: Indiana Acad. Sci., Proc., 1917, pp. 221-226, 1918.

583. Certain indicia of dip in rocks: Indiana Acad. Sci., Proc., 1917, pp. 229-234, 7 figs., 1918.

Longyear, Robert Davis.

Genesis of the Sudbury nickel-copper ores as indicated by recent explorations. See Roberts and Longyear, no. 791.

Exploration of nickel-copper properties in Falconbridge township, Sudbury district, Ontario. See Roberts and Longyear, no. 792.

Origin of Sudbury nickel-copper deposits. See Roberts and Longyear, no. 793 .

Loomis, F. B.

584. An unusual mastodon: Am. Jour. Sci., 4th ser., vol. 45 , pp. $438-444,4$ figs., June, 1918.

Louderback, George D.

585. Californian manganese problem: Min. and Sci. Press, vol. 116, pp. 451452, March 30, 1918.

Loughlin, G. F.

586. I.ime in 1916.: U. S. Geol. Survey, Mineral Resources, 1916, pt. 2, pp. 433-462, March 11, 1918.

587. Stone in 1916: U. S. Geol. Survey, Mineral Resources, 1916, pt. 2, pp. 993-1078, 1. pl., 2 figs., November 25, 1918:

588. Slate in 1917: U. S. Geol. Survey, Mineral Resources, 1917, pt. 2, pp. 121-138, 1 fig., July 30, 1918.

389. Two lamphrophyre dikes near Santaquin and Mount Nebo, Utah: U. S. Geol. Survey, Prof. Paper 120, np. 101-109, 1 fig. (map), June 14, 1918.

590. The oxidized zinc ores of Leadville, Colorado: U. S. Geol. Survey, Bull. 681, 91 pp., 8 pls., 7 figs., 1918.

591. Zinc carbonate and related copper carbonate ores at Ophir, Utah (U. S. Geol. Survey, Bull. 690-A, 1917) : Abstract, by R. W. Stone, Washington Acad. Sci., Jour., vol. 8, no. 5, pp. 129-130, March 4, 1918.

Lucas, Anthony F.

592. Principles and problems of oil prospecting in the Gulf coast country (discussion) : Am. Inst. Min. Eng., Bull. no. 136, pp. 823-824, April, 1918.

593. A review of the exploration at Belle Isle, Louisiana: Am. Inst. Min. Eng., Trans., vol. 57, pp. 1034-1046, 2 figs. (with discussion by I. N. Knapp and others, pp. 1046-1049), 1918. 
Lucas, Anthony F.-Continued.

594. Pcssible existence of deep-seated oil deposits on the Gulf coast: Am.

Inst. Min. Eng., Bull. no. 139, pp. 1119-1134, 5 figs., July, 1918.

Discussion by G. S. Rogers, Bull. no. 142, pp. 1558-1560, October, 1918.

See also Matteson, no. 634 .

Iucke, P. K.

595. The relation of sulphides to water level in Mexico: Am. Inst. Min. Eng., Bull. no. 138, pp. 1105-1108, 3 figs., June, 1918.

Lugeon, Maurice, and Sigg, Henri.

596. Sur quelques roches éruptives de la Caroline du Nord: Soc. vaudoise sci. nat., Bull., vol. 52, pp. 99-112, October 2, 1918.

Lull, Richard Swann.

597. Organic evolution; a textbook. 729 pp., 30 pls., 253 figs., New York, The Macmillan Company, 1917.

598. [Editor] The evolution of the earth and its inhabitants. 208 pp:, 2 pls., 38 figs., New Haven, Yale University Press, 1918.

599. The pulse of life. In The evolution of the earth and its inhabitants, pp. 109-146, 17 figs., New Haven, Yale University Press, 1918.

600. Fossil footprints from the Grand Canyon of the Coloratio: Am. Jour: Sci., 4th ser., vol. 45, pp. 337-346, 3 figs., May, 1918.

601. On the development of vertebrate paleontology: Am. Jour. Sci., 4th ser., vol. 46, pp. 198-221, July, 1918. Reprinted in A century. of science in America, pp. 217-247, New Haven, 1918.

Lupton, C. T.

Anticlines in the southern part of the Big Horn Basin, Wyoming. See Hewett and Lupton, no. 432.

McCallie, S. W.

602. Handbook, mineral resources of Georgia. Revised edition. Georgia Geol. Survey, 48 pp., illus., 1918.

IMcCaskey, H. D., and Dunlop, J. P.

603. Gold and silver in 1916 (general report) : U. S. Geol. Survey, Mineral Resources, 1916, pt. 1, pp. 679-721, 1 pl., 1 fig., May 7, 1918.

MacCaughey, Vaughan.

604. A survey of the Hawaiian coral reefs: Am. Naturalist, vol. 52, pp. 409-438, 9 figs., August-September, 1918.

McCaughey, William J.

605. Copiapite in coal: Am. Mineralogist, vol. 3, no. $8,{ }^{\natural}$ pp. 162-163, August, 1918.

IIcCourt, Walter Edward, assisted by Albertson, M., and Benne, J. W.

606. The geology of Jackson County: Missouri Bur. Geology and Mines, 2d ser., vol. 14, 158 pp., 22 pls. (incl. maps), 1917.

McCoy, A. W.

607. On the migration of petroleum through sedimentary rocks: Am. Assoc. Petroleum Geologists, Bull., vol. 2, pp. 168-171, 1918.

MacDonald, Bernard.

608. Remarks on the Sonora earthquake; its behavior at Tepic, Sonora, etc.: Seismol. Soc. America, Bull., vol. 8, nos. 2-3, pp. 74-78, June-September, 1918. 
MacLean, A.

609. Lignite area of southern Saskatchewan: Ganada Geol. Survey, Summ. 'Rept., 1917, pt. C, pp. :35-41, :1918.

McLaughlin, D. H.

Further remarks on the ores of Engels, California. See Graton and McLaughlin, no. 362 .

McLearn, F. H.

610. Peace River section, Alberta: Canada Geol. Survey, Summ. Rept., 1917, pt. C, pp. 14-21, 1918.

611. The Silurian Arisaig series of Arisaig, Nova Scotia : Am. Jour. Sci., 4th ser., vol. 45, pp. 126-140, Februàry, 1918.

612. Revision of some phacopid genera: Ottawa Naturalist, vol. 32, no. 2, pp. 31-36, May, 1918.

MrcLeish, John.

613. Annual report on the mineral production of Canada during the calendar year 1916: Canada, Dept. Mines, Mines Branch, 343 pp., $191 \mathrm{~S}$.

Mackenzie, John David.

614. The geology of Graham Isiand, British Columbia. Abstract of thesis, Massachusetts Institute of Technology. $10 \mathrm{pp}$., 1916.

Mailhiot, Adhémar.

615. Geology of a portion of the projected township of Lemieux, County of Gaspe, P. Q.; comprising a description of the zinc and lead deposits at the head of Berry Mountain Greek, a tributary of the Great Cascapedia River: Quebec (-Province), Bept. of Colonization, Mines, and Fisheries, Rept. on mining operations, 1917, .pp. 117-145, 3 pls., 2 figs., map, 1918.

Malcolm, Wyatt.

616. Hints on prospecting for a few Canadian:minerals.: Canadian Min. Inst., Mo. BBull., no. :76, pp. 692-704, August, 1918.

Manchester, James G., and Bather, William T.

617. Famous mineral localities; Mt. Mica, Mt. Apatite, and other localities in Maine: Am. Mineralogist, vol. 3, no. 9, pp. 169-174, 2 pls., September, 1918.

Mansfield, George R.

618. Origin of the western phosphates of the United States: Am. Jour. Sci., 4 th ser., vol. 46 , pp. 591-598, October; 1918.

618a. Sulphur in Jemez Canyon, New Mexico: Eng. and Min. Jour., vol. 106, p. 449, September 7, 1918. [In error attributed to Philip S. Smith.]

Mansfield, Wendell $\mathrm{C}$.

619. Molluscan fauna from the calcareous marls in the vicinity of Deland, Volusia Co., Florida: Florida State Geol. Survey, 10th and 11th Ann. Repts., pp. 111-123, 4.figs., 1918.

Manson, Marsden.

620. Progressive deglaciation and the amelioration of climate: Science, new ser., vol. 47, pp. $487-488$, May $17,1918$. 
Marshall, J. R.

62.1. Gold-bearing district of southeastern Manitoba: Canada, Geol. Survey, Summ. Rept., 1917, pt. D, pp. 17-21, 1918.

622. Star Iake area, Manitoba: Canada, Geol. Survey, Summ. Rept., 1917, pt. D, pp. 21-22, 1918.

Martin, G. C.

623. Gold, silver, copper, and lead in Alaska in 1917; mines report: U. S. Geol. Survey, Mineral. Resources, 1917, pt. 1, pp. 131-145, November 21, 1918.

Martin, Lawrence.

624. Gravel terraces of the Mississippi River in Wisconsin (abstract); Assoc. Am. Geographers, Annals, vol. 7 , p. 79 [191:8].

Mather, Kirtley F.

625. Diminution of the Antarctic ice cap and the amelioration of climate: Science, new ser., vol. 47, pp. 218-219, March 1, 1918.

626. Superficial dip of marine limestone strata (abstract) : Science, new ser., vol. 47, p. 470, May 10, 1918.

627. Superficial dip of marine limestone strata; a factor in petroleum geology : Econ. Geology, vol. 13, no. 3, pp. 198-206, 2 pls., 2 figs., May, 1918.

628. Paralles from paleontology: Atantic Monthly, vol. 122, no. 1, pp. 35-43, July, 1.918.

Structure and oil and gas resources of the Osage Reserration, Oklahoma; Tps. 24 and 25 N., R. 8 E. See Heald and Mather, no. 425.

Structure and oil and gas resources of the osage Reservation, Oklahoma; T. 20 N., R. 11 E. See Iloyd and Mather, no. 579.

\section{Mathews, Edward Bennett.}

629. Wm. Bullock Clark, Ph. D., IL. D., State geologist, 1896-1917 : Maryland Geol. Survey, vol. 10, pp.:31-37, port., 1918.

The surface and underground water resources of Maryland, including Delaware and the District of Columbia. See Clark and others, no. 179.

Matson, George Charlton.

630. Louisiana clays, including results of tests made in the laboratory of the Burean of :Standards at Pittsburgh :(U. S. Geol. Survey, Bull. 660-E, 1917) : Abstract, by R. W. Stone, Washington Acad. Sci., Jour., vol. :8, no. 7, p. 205, April 4, 1918.

Matson, G. C., and Hopkins, O. B.

63. The DeSoto-Red River oil and gas field, Louisiana (U. S. Geol. Survey, Bull. 661-C, 191.7) : Abstract, by R. W. Stone, Washington Acad. Sci., Jour., vol. 8, no. 2, pp. 35-36, January 19, 1918.

632. The Corsicana oil and gas field, Texas (:U. S. Geol. Survey, Bull. 661-F, 1917) : Abstract, by R. W. Stone, Washington Acad. Sci., Jour., vol. $\$$, no. 2, pp.' $36-37$, January $19,191.8$.

Matteson, W. G.

633. The practical value of oil and gas bureaus: Am. Inst. Min. Eng., Trans., vol. 57, pp. 1010-1012 (with discussion by T. G. Woodruff, I. N. Knapp, A. F. Iucas, L. L. Hutchison, William Kennedy, H. M. Ami, W. Van der Giracht, Dorsey Hager, W. E. Wrather, and the author, pp. 1012-1.033), 1918. 
Matteson, W. G.-Continued.

634. Principles and problems of oil.prospecting in the Gulf coast country; Am. Inst. Min. Eng., Trans., vol. 59, pp. 435-469, 5 figs., (with discussion by A. F. Iucas, G. S. Rogers, E. W. Shaw, Eugene Coste, Kirby. Thomas, William Kennedy, C. W. Washburne, and the author, pp. 469-491, 704-705), 1918; Bull. no. 134, pp. 429-468, February, 1918, and disçussion, no. 136, pp. 823-835, April, no. 139, pp. 1145-1146, July, no. 140; pp. 1163-1164, August, 191.S.

635. Age of the oil in southern Oklahoma fields (discussion) : Am. Inst. Min. Eng., Bull. no. 136, p. 842, April, 1918.

Matthes, F. E.

636. The Mount Rainier National Park. [Text on back of topographic map], Washington, Mt. Rainier National Park, U. S. Geol. Survey, 1916.

637. The country around Camp Mcclellan. [Text on bạck of topographic map], Alabama, Anniston quadrangle, Camp McClellan, U. S. Geological Survey, 1918.

638. The country around Camp Gordon [near Atlanta, Georgia]. [Text on back of topographic map], Georgia, Camp Gordon and vicinity, U. S. Geol. Survey, 1918.

Matthew, William Diller.

639. A Paleocene bat: Am. Mus. Nat. Hist., Bull., vol, 37, pp. 569-571, 1 fig., 1917.

640. Absence of the pollex in Perissodactyla: Am. Mus. Nat. Hist., Bull., vol. 37 , pp. 573-577, 1917.

641. The dentition of Nothodectes: Am. Mus. Nat. Hist., Bull., vol. 37, pp. 831-839, 4 pls., 1917.

642. The mounted skeleton of Moropus in the American Museum: Am. Mus. Jour., vol. 18, no. 2, pp. 121-123, 2 figs., February, 1918.

643. Skeletons of the Cuban ground sloth in the Havana and American museums : Am. Míus. Jour., vol. 18, no. 4, p. 313, 2 figs.. April, 1918.

644. A Tertiary alligator: Am. Mus. Jour., vol. 18, no. 6, pp. 505-506, 1 fig., October, 1918.

645. Generic nomenclature of the Proboscidea (abstract) : Geol. Soc. America, Bull., vol. 29 , no. 1, p. 141, March $31,1918$.

646. Affinities and phylogeny of the extinct Camelidae (abstract) : Geol. Soc. America, Bull., vol. 29, no. 1, p. 144, March 31, 1916.

647. Notes on American Pliocene rhinoceroses (abstract) : Geol. Soc. America, Bull., vol. 29, no. 1, p. 153, March 31, 1918.

Matthew, W. D., and Granger, Walter.

648. The skeleton of Diatryma, a gigantic bird from the lower Eocene of Wyoming: Am. Mus. Nat. Hist., Bull., vol. 37, pp. 307-326, 14 pls., 1 fig., 1917.

649. Fossil mammals of the Tiffany beds (abstract): Geol. Soc. America, Bull., vol. 29, no. 1, p. 152, March 31, 1918.

Maury, Carlotta J.

650. Santo Domingan paleontological explorations: Jour. Geology, vol. 26, no. 3, pp. 224-228, April-May, 1918.

Meade, Richard $\mathrm{K}$.

651. Strontium; its occurrence, industrial application, and the manufacture of its salts: Mineral Foote-Notes, vol. 2, no. 2, pp..2-12, February, 1918. 
Meinzer, Oscar E.

652. Ground water for irrigation in Lodgepole Valley, Wyoming and Nebraska (U. S. Geol. Survey, Water-Supply Paper 400-B, 1917) : Abstract; Washington Acad. Sci., Jour., vol. 8, no. 3, p. 65, February 4, 1918.

653. Geology and water resources of Big Smoky, Clayton, and Alkali Spring valleys, Nevada (U. S. Geol. Survey, Water-Supply Paper 423, 1917) : Abstract, Washington Acad. Sci., Jour., vol. 8, no. 4, pp. 95-96, February 19, 1918.

654. The geologist in war times; relation to military supplies (discussion) : Econ. Geology, vol. 13, no. 4, pp. 314-315, June, 1918.

655. Bibliography and index of the publications of the United States Geological Survey relating to ground water: U. S. Geol. Survey, WaterSupply Paper 427, 169 pp., 1 pl. (map), 1918.

656. The glacial history of Columbia River in the Big Bend region (abstract) : Washington Acad. Sci., Jour., vol. 8, no. 12, pp. 411-412, June 19, 1918.

Ground water in Quincy Valley, Washington. See Schwennesen and Meinzer, no. 837.

See also Schwenuesen, no. 835 .

Merriam, John C.

657. New Mammalia from the Idaho formation: California, Univ., Dept. Geology, Bull., vol. 10, no. 26, pp. 523-530, 5 figs., April 20, 1918.

658. Note on the systematic position of the wolves of the Canis dirus group: California, Univ., Dept. Geology, Bull., vol. 10, no. 27, pp. 531-533, April 20, 1918.

659. New puma-like cat from Rancho La Brea: California, Univ., Dept. Geology, Bull., vol. 10, no. 28, pp. 535-537, 2 figs., April 20, 1918.

660. Evidence of mammalian paleontology relating to the age of Lake Lahontan: California, Univ., Dept. Geology, Bull., vol. 10, no. 25, pp. 517-521, September 4, 1918.

661. Fauna of the Idaho formation (abstract) : Geol. Soc. America, Bull., vol. 29, no. 1, p. 162, March 31, 1918.

IMerrill, George $P$.

662. A second meteorite find in Florida [Eustis, Lake County]: Am. Jour. Sci., 4th ser., vol. 45, pp. 64-65, January, 1918.

663. A peculiar fibrous form of opal: Am. Mineralogist, vol. 3, no. 2, pp. 1112, February, 1918.

664. Further notes on the Plainview, Texas, meteorite: U. S. Nat. Mus., Proc. vol. 54, pp. 503-505, 2 pls., 1918.

665. On the Fayette County, Texas, meteorite finds of 1878 and 1890 and the probability of their representing two distinct falls: U. S. Nat. Mus., Proc., vol. 54, pp. 557-561, 2 pls., 2 figs., 1.918.

666. Tests for fluorine and tin in meteorites with notes on maskelynite and the effect of dry heat on meteoric stones: Nat. Acal. Sci., Proc., vol. 4 , no. 6 , pp. 1.76-1.80, 1. pl., June, 191.8.

667. Lazulite in an unusual form: Am. Mineralogist, vol. 3, no. 11, p. 192. November, 191.S.

See also Taber, no. 924.

IMertie, J. B., jr.

668. The gold placers of the Tolovana district, Alaska (U. S. Geol. Survey, Bull. 662-D, 1917) : Abstract, by R. W. Stone, Washington Acad. Sci., Jour., vol. 8, no. 13, pp. 454-455, July 19, 1918. 
Merwin, H. E.

The melting points of cristobalite and itiidymite. See Terguson and Merwin, no. 308 .

The ternary system $\mathrm{MgO}-\mathrm{Al}_{2} \mathrm{O}_{3}-\mathrm{SiO}_{2}$. See Rankin and Herwin, no. 773.

Middleton, Jefferson.

669. Clay-wolking industries and building operations in the larger cities in 1916: U. S. Geol. Survey, Mineral Resources, 1916, pt. 2, pp. 511-583, 1 fig., April 13, 1918.

670. Fuller's enth in 1917: U. S. Geol. Survey, Mneral Resources, 1917, pt. 2, pp. 253-255, Septemiber 18, 1918.

Miller, A. M.

67.1. Map of Georgetown quadrangle: Kentucky Geol. Survey, 1917.

Miller, Eric Rexford.

The dustfalls of March, 1918. :See Winchell and Miller, no. 1063.

The dustfalls of March 9, 1918. :See Winchell and 'Mriller, no. 1062.

Miller, Willet G.

672. Lateritic ore deposits; with comments on the nature of laterites in general: Ontario Bur. Mines, 26th Ann. Rept., 1917, vol. 26, pp. 318-334, illus., 1917.

673. Genesis of the Sudbury nickel-copper ores (discussion) :: Am. Inst. Min. Eng., Bull. no. 136, pp. 851-853, April, 1918.

See also Ròberts and Longyear, no: 7.91.

Miller, Willet:G., and Knight, Cyril W.

674. Euxenite, a radioactive mineral in South Sherbrooke township, Lanark County: Ontario Bur. Mines, 26th Ann. Rept., 1917, vol. 26, pp. $314-317,1917$.

Mriller, William J.

675. Take Placid quadrangle, Schroon Take quadrangle: New York State Mus., Bull. no. 196, pp. 29-31, April 1, 1917 [1918].

6776. Adirondack anorthosite (abstract, with discussion by W. S. Bayley and F. F. Grout) : Geol. Soc. America, Bull. vol. 29, no. 1, pp. 99-100, March 31, 1918.

677. Adirondack anorthosite: :Geol. Soc. America, Bull., vol. 29, no. 3, pp. 399-462, 3 figs. (incl. map), September 30, 1918.

679. Banded structures of the Adirondack syenite-granite series. Science, new ser., vol. 48 , pp. 560-563, Deceniber 6, 1918.

See.also Grout, no. 37.; W:ilson, no. 1060.

Miller, W. Z.

Low-angle faulting. See Chamberlin and Miller : no. 161.

Miser, 酉. D.

Possibilities for manganese ore on certain undeveloped tracts in

Shenancloah Valley, Virginia. See Hewett and.other's, no. 430 .

Camp Pike and the adjacent country [Airkansas]. iSee Stephenson and Miser, no. :910.

Thiser, ${ }^{7} \mathrm{Hugh}$ D., and Purdue, A. H.

679. Asphalt deposits and oil conditions in southwestern Arkansas: U. S.

Geol. Survey, Bull. 691, pp. 271-292, 1 pl. (map), Angust 16.- 1918.

680. Gravel deposits of the Gaddo Gap and De Queen quadrangles, Arkansas :

U. S. IGeol. Survey, Bull. 690, ipp. 15-29, 3 pls., (incl. map), 2 figs., .June 14, 1918. Albstract, Washington Acad. Sci., Jour., vol. 8, no. 15, p. 538, :September 19, 1918. 
Mitchell, Graham John.

681. Evidence of recent changes of level in:Porto Rico, as shown by studies in the Ponce district (abstract) : Geol. Soc. America, Bull., vol. 29, no. 1, pp. 13s-141, March 31, 1918.

Mitchell, Guy Elliott.

682. Billions of barrels of oil locked up in rocks; Nat. Geog. Mag., vol. 33, no. 2, pp. 195-205, illus., February, 1918.

Moffit, Fred :H.

683. The upper Chitina Valley, Alaska: U. S. Geol. Survey, Bull. 675, 82 pl., 13 pls. (incl. maps), 2 figs., 1918.

\section{Montoulieu, Eduardo I.}

684. The mining industry in the Republic of Cuba: The Cuba Review, vol. 16, no. 12, pp. 12-26, Novemiber, 1918.

Moodie, Roy :L.

685. Diseases of the mosasaurs (abstract) : Geol. Soc. America, Bull., vol. 29 , no. 1, p. 14.7, March $31,1918$.

686. Paleontological evidence of the antiquity of disease: Sci. Monthly, vol. 7 , no. 3, pp. 265-281, 21 figs., September, 1918.

687. Synthesis of paleontology and medical history: Science, new ser., vol. 4.8, pp. 619-620, December 20, 1918.

Moody, C. L., and Taliaferro, N. L.

688. Anticlines near Sunshine, Park County, Wyoming: Calitornia, Univ., Dept. Geology, Bull., vol. 10, no. 23, po. 445-459, 5 pls., 1 fig., January 31, 1918.

Mook, Charles C.

689. Criteria :for the determination of species in the:Sauropoda, with description of a new species of Apatosaurus: dm. Mus. Nat. Hist., Bull., vol. 37 , pp. $355-360,2$ figs., 1917 .

690. The fore and hind limbs of Diploulocus: Am. Mus. Nat. Hist.. Bull. rol. 37, pp. 815-819, 2 figs., 1917.

691. The habitat of the samropod dinosaurs: Jour. Geology, vol. 26, no. 5, pp. $-459-470$, July-August, 1918.

Moore, E. S.

692. Iron deposits on the Belcher Islands, Hudson Bay: Canadian Min. Inst., Rull. no. 82, pp. 196-206, 4 figs., February. 1919.

693. The iron formation on Belcher Islands, Hudson Bay, with special refence to its origin and its associated algal limestones: Jour. Geology, vol. 26, no. 5, pp. 412-438, 19 figs., July-August, 1918. Abstract, Geol. Soc. America, Bull., vol. 29, no. 1, p. 90, March 31. 1918.

694. Algal limestone on the Belcher Islands, Hudson Bay (abstratct) : Geol. Soc. America, Bull. rol..29, no. 1, p. 128, March 31., 1918.

Moore, Raymond C

695. The environment of Camp Funston; with a chapter on the western theatre of war by D. W. Johnson: Kansas State Geol. Survey, Bull. 4, 81 pp., 11 pls., (incl. maps), 37 figs., 1918.

696. Geologic history of crystalline rocks of Kansas: Am. Assoc. Petroleum Geologists, Bull., vol. 2, pp. 9S-11.3, 1.918.

IVoore, Raymond C., and Haynes, Winthrop P.

697. Oil and gas resources of Kansas: Kansas Geol. Survey, Bull. 3, 391 pp., 40 pls. (incl. maps), 24 figs., 1917. 
Moore, Richard B.

698. Radium ore deposits : Eng. and Min. Jour., vol. 106, pp. 392-393, August 31, 1918.

Moore, S. R.

699. Geology of the Success mine [Coeur d'Alene district, Idaho] ; Min. and Sci. Press, vol. 116, p. 8, January 5, 1918.

Muir, A. H.

700. The geology of the artesian water supply of the San Antonio area. 42 pp., 6 pls. (incl. maps), St. Louis, Mo., A. R. Fleming Printing Co., 1911.

MIuir, John.

701. The glaciation of the Arctic and sub-Arctic regions visited during the cruise. In his The cruise of the Corvin; journal of the Arctic expedition of 1881 in search of De Long and the Jeannette, edited by William Frederic Badè, pp. 235-258, Boston, Houghton Mifflin Company, 1917.

702. Studies in the Sierra, No. IV; Glacial denudation: Sierra Club Bull., vol. 10, no. 3, pp. 304-318, 10 figs., January, 1918.

IMulholland, William.

703. Earthquakes in their relation to the Los Angeles aqueduct: Seismol. Soc. America, Bull. vol, 8, no. 1, pp. 13-19, 3 figs., March, 1918.

IIúñoz, Lumbier, Manuel.

704. La seismología en México hasta 1917; México, Inst. Geol., Bol. no. 36, 102 pp., pls., 1918.

Nash, James $\mathbf{P}$.

The geology of Valverde County. See Roberts and Nash, no. 794.

Nason, Frank L.

705. Characteristics of zinc deposits in North America: Am. Inst. Min. Eng., Trans., vol. 57, pp. 830-855, 10 figs., (with discussion by H. A. Buehler, J. T. Boyd, and the author, pp. 855-862), 1918.

Nattress, Thomas.

706. On the prospect of oil being found under the Ontario-Ohio-Michigan section of Lake Erie: Michigan Acad. Sci., 19th Ann. Rept.; pp. 8794, 1 fig., 1917.

Nelson, N. C.

707. Additional studies in the Pleistocene at Vero, Florida: Science, new ser., vol. 47, pp. 394-395, April 19, 1918.

Newland, D. H.

708. Plastic deformation of Grenville limestone: New York State Mus. Bull. no. 196, pp. 145-147, 6 pls., April 1, 1917 [1918].

709. The mining and quarry industry of New York State; report of operations and production during 1916: New York State Mus. Bull. no. 196, pp. 247-304; April 1, 1917 [1918].

Newton, Edmund.

710. Manganiferous iron ores of the Cuyuna district, Minnesota: Minnesota, Univ., Minnesota School of Mines, Exper. Sta., Bull. no. 5, 126 pp., 5 figs., map, 1918.

Nicolls, J. H. H.

Analyses of Canadian fuels. See Stansfield and Nicolls, no. 899. 
Northrop, John D.

711. Natural gas in 1916: U. S. Geol. Survey, Mineral Resources, 1916, pt. 2, pp. 5\$5-678, 5 figs., May 4, 1918.

712. Petroleum in 1916: U. S. Geol. Survey, Mineral Resources, 1916, pt. 2, pp. 679-886, 3 figs., April 26, 1918.

713. Asphalt, related bitumens, and bituminous rock in 1917: U. S. Geoi. Survey, Mineral Resources, 1917, pt. 2, pp. 233-251., 2 figs., October 22, 1918.

Notestein, Frank B.

714. Some chemical experiments bearing on the origin of certain uraniumvanadium ores: Econ. Geology, vol. 13, no. 1, pp. 50-64, January, 1918 .

O'Connell, Marjorie.

715. Notes on the geology of Oesel in the Gulf of Riga (abstract) : New Iork Acad. Sci., Annals, vol. 27, p. 273, November 30, 1917.

716. George Jennings Hinde: Science, new ser., vol. 48, pp. 588-590, December 13,1918 .

Were the graptolite shales, as a rule, deep or shallow water deposits? See Grabau and O'Connell, no. 356.

O'Harra, C. C.

717. The geology of petroleum deposits : Pahasipa Quart., vol. 7, no. 2, pp. 1737, 21 figs., Februirry, 1918.

Ohern, D. W.

718. A contribution to the stratigraphy of the red beds: Am. Assoc. Petroleum Geologists, Bull., vol. 2, pp. 114-117, 1 fig. (map), 191.8.

Oldroyd, Ida S.

719. Relationships of recent and fossil invertebrate faunas on the west side of the Isthmus of Panama to those on the east side (abstract) : Geol. Soc. America, Bull., vol. 29, no. 1, p. 162, March 31, 1918.

O'Neill, J. J.

720. Economic geology of the Hazelton district, British Columbia: Canada, Geol. Survey, Summ. Rept., 1917, pt. B, pp. 9-12, 1918.

Ordóñez, Ezequiel.

721. Oil in southern Tamaulipas, Mexico: Am. Inst. Min. Eng., Bull. no. 137, pp. 1001-1008, 3 figs., May, 1918. Discussion by V. R. Garfias and E. DeGolyer, Bull. no. 142, pp. 1560-1564, 1 fig., October, 1918.

Ortega, Pablo.

Geology of Cuba. See Hayes and others, no. 421.

Osbon, C. C.

722. Peat in 1917: U. S. Geol. Survey, Mineral Resources, 1917, pt. 2, pp. 257-283, 1 pl. (map), December 19, 1918.

Osborn, Henry Fairfield.

723. Equidae of: the Oligocene, Miocene, and Pliocene of North America, iconographic type revision: Am. Mus. Nat. Hist., Mem., new ser., vol. 2 , pt. 1, pp. 1-330, 54 pls., 173 figs., May, 1918.

724. Samuel Wendell Williston, 1S52-1918: Jour. Geology, vol. 26, no. 8, pp. 673-689, November-December, 1918.

725. Observations on the skeletons of Moropus coolki in the American Museum (abstract): Geol. Soc. America, Bull. vol. 29, no. 1, pp. 131-133, March 31, 1918. 
Osborn, Henry Fairfield-Continued.

726. A long-jawed mastolon skeleton from South Dakota and phylogeny of the Proboscilea (abstract) : Geol. Soc. America, Bull., vol. 29, no. 1, pp. 133-137, March 31, 1918.

Overbeck, R. M.

727. Igneous rocks [of the upper Chitina Valley; Alaska] : U. S. Geol. Survey, Bull. 675, pp. 52-66, 1918.

Pack, Robert W.

728. The estimation of petroleum reserves: Am. Inst. Min. Eng., Trans., vol. 57, pp. 968-981, 6 figs. (discussion by .C. W. Washburne, pp. 981983), 1918.

Paige, Sidney, and Steiger, George.

7.29. Fluorine in sericitization: Washington Acad. Sci., Jour., vol, S, no. S, pp. 234-239, 2 tigs., April 19, 1918.

Palacios, Enrique Juan.

730. Indicaciones petrolíferas en la costa del Pacífico: Soc. cient. "Antonio Alzate," Mem., t. 37, no. 1, pp. 61-64, May, 1918.

Palmer, Andrew $\mathrm{H}$.

731. California earthquakes during 1917: Seismol. Soc. America, Bull., vol. 8, no. 1, pp. 1-12, 1 pl., March, 1918.

Palmer, Harold S.

732. New graphic method for determining the depth and thickness of stratit and the projection of dip:: $\mathrm{U}$. S. Geol. Survey, Prof. Paper 120, pp. 123-128, 3 pls., 5 figs., August 21, 1918.

Palmer, Irving A.

733. Manganese: Colorado School of Mines Mag., vol. 8, no. 4, pp. 55-57, April, 1918.

Palmer, Leroy A.

734. The Calico district, California: Min. and Sci. Press, vol. 116, pp. 75i758, 4 figs., June 1, 1918.

Panyity, L. S.

735. The southern extremity of the "Clinton." gas pools in Ohio: Am. Inst. Min. Eng., Trans., vol. 57, pp. 984:988, 3 figs., 1918.

736. Lithology of the Berea sand in southeastern Ohio, and its effect on production: Am. Inst. Min. Eng., Bull. no. 140, pp. 1317-1320, 4 tigs., August, 1918.

Pardee, .J. T.

737. The Dunkleberg mining district, Granite County, Montana (U. S. Geol. Survey, Bull. 660-G, 1917) : Abstract, Washington Acarl. Sci., Jour., vol. 8, no. 8, p. 249, April 19, 1918.

738. Ore deposits of the northwestern part of the Garnet Range, Montana : U. S. Geol. Survey, Bull. 660, pp. 159-239, 4 pls. (incl. :map), 10 figs., January 10, 1918. Abstract, Washington Acad. Sci., Jour., vol. 8 , no. 9 , เp. 290 , May 4,1918 .

739. Manganese at Butte. Montana: :U. S. Geol. Survey, Bull. 690, pp. 111130, April 9, 1918. Abstract, by R. W. Stone. Washington Acad. .Sci., Jour., vol. 8, no. 13, pp. 450-451, July 19, 1918.

740. Some manganese deposits in Madison Gounty, Mrontana: U. S. Geol. Survey, Bull. 660, pp, 131-134, July \&, 1918. 
Pardee, J. T.-Continued.

741. Geology and mineral deposits of the Colville Indian Reservation, Washington: U. S. Geol. 'Survey, Bull. 67.7, 1.86 pl., 12 pls. (incl. map), 1 fig. 1918.

Pardee, J. T., and Parks, Henry M.

742. Manganese deposits near Lake Creek, Oregon: Eng. and Min. Jour., vol. 106, pp. 872-873, November $16,1918$.

\section{Parks, Henry M.}

Manganese deposits near Láke Creek. Oregon. See Pardee and Larks, no. 742 .

Parks, Wm. A.

743. Report on the building and ornamental stones of Canada; vol. V, Province of British Columbia : Canada, Dept. Mines, Mines Branch, 236 pp., 47 pls., 3 figs. (maps), 1917.

Parsons, Arthur L.

744. Molybdenite deposits of Ontario: Ontario Bur. Mines, 26th Ann. Rept. 1917, vol. 26, pp. 275-313, 21 figs, maps. 1.917.

745. Slate Islands, Lake Superior.: Ontario Bur. Mines, 27th Ann. Rept. 1918, p. 155-167, 15 figs. (incl. map), 1918.

746. Mineral developments in northwestern Ontario: Ontario Bur. Mines, 27th Ann. Rept., 1918, pp. 168-186, 1 pl. (map), 1.6 figs., 1918.

Parsons, Charles L.

74.7. Icelind spar in Montana: Science, new ser., vol. 47, pp. 508-509, Maty 24, 1918. Abstract, Min, and Sci. Press, vol. 1.16, p. 824, June 15, 1918.

Peck, Albert B.

Some new thermo-optical observations in gypsum and glauberite. See Kriaus and Peck, no. 536.

Pemberton, J. R.

748. A résumé of the past year's development in Kentucky [oil fields] from a geologic standpoint: Am. Assoc. Petroleum Geologists, Bull., vol. 2, pp. 38-52, 1 fig., 1918.

Penrose, R. A. F., Jr.

749. Memorial of Amos P. Brown : Geol. Soc. America, Bull., vol. 29, no. 1, 111. 13-17, port., March :31, 1918.

\section{Perikins, George $\mathrm{H}$.}

750. Memorial of Henry Martyn Seely: Geol. Soc. America, Bull., vol. 29, no. 1, pp. 65-69, port., March 31, 1918.

\section{Perrine, Irving.}

751. Geological conditions in centlal Kausas: Am. Assoc. Fetroleum Geologists, Bull., vol. 2, pp. 70-97, 1918.

Perry, E. S.

752. Tripoli deposits of Oklahoma: Oklahoma Geol. Surrey, Bull. no. 28, 32 pp., 18 figs., July, 1917.

Peterson, O. A.

753. New artiodactyls from the upper Eocene of the Uinta Basin, Utah (abstract) : Geol. Soc. America, iBull, fol. 29, no. 1., p. 158, March 31, 1918. 
Phillips, Alexander $\mathrm{H}$.

754. A possible source of vanadium in sedimentary rocks: Am. Jour. Scl., 4th ser., vol. 46, pp. 473-475, August, 1918.

Phillips, William B.

755. The sulphur deposits in Culberson County, Texas: Am. Inst. Min. Eng., Trans., vol. 58, pp. 265-282, 1 fig. (with discussion p. 283), 1918.

Pilsbry, Henry A.

756. Cirripedia from the Panama Canal Zone: U. S. Nat. Mus., Bull. 103, pp. 185-188, 1 pl. 1918.

Pirsson, Louis V.

757. The rise of petrology as a science: Am. Jour. Sci., 4 th ser., vol. 46 , pp. $\because \quad 222-239$, July, 1918. Reprinted in A century of science in America, pp. 24S-267, New Haven, 1918.

Pogue, Joseph E.

758. Optical fluorite in southern Illinois: Illinois State Geol. Survey, Extr. from Bull. no. 38, 8 pp., 1 fig., 1918.

759. A laboratory method of teaching elementary crystallography: Am. Mineralogist, vol. 3, nos. 10 and 11, pp. 179-182, 193-194, October and November, 191.8.

The mineral industries of the United States; coal, the resource and its full utilization. See Gilbert and Pogue, no. 384.

Petroleum; a resource interpretation. See Gilbert and Pogue, no. 335.

Poitevin, Eugene.

760. Notes on the origin of colerainite: Roy. Soc. Canada, Trans., ser. 3, rol. 12, sec. 4, pp. 37-39, June and September, 1918.

Poitevin, Eugene, and Graham, R. P. D.

761. Contributions to the mineralogy of Black Lake area, Quebec: Canada, Geol. Survey, Mus. Bull. nọ. 27, 82 pp., 12 pls. (incl. map), 22 figs., February 28, 1918.

Powers, Sidney.

762. Age of the oil in southern Oklahoma fields: Am. Inst. Min. Eng., Trans., vol. 59, pp. 564-575, 3 figs. (with discussion by W. E. Pratt and W. G. Matteson, pp. 576-577), 1918.

763. Letter concerning San Salvador eruption: Zeitschr. Vulkanologie, Bd. 4, H. 2-3, p. 201, June, 1918.

764. Notes on the geology of eastern Guatemala and northwestern Spanish Honduras: Jour. Geology, vol. 26, no. 6, pp. 507-523, 4 figs., September-October, 1918.

Pratt, Wallace E.

765. Age of the oil in the southern Oklahoma fields (discussion) : Am. Inst. Min. Eng., Bull. no. 135, pp. 708-709, March, 1918.

766. Geology of the oil fields of north central Texas (discussion) : Am. Inst. Min. Eng., Bull. no. 140, pp. 1155-1156, August, 1918.

Price, W. Armstrong.

767. Notes on the paleontology of Barbour, Upshur, and western portion of Randolph counties; invertebrate fossils from the Conemaugh and Pottsville series: West Virginia Geol. Survey, Barbour and Upshur counties, pp. 777-804, 1 pl., 2 figs., 1918.

768. The Kanawha black flint and other cherts of West Virginia (austract) : Science, new ser., vol. 47, pp. 468-469, May 10, 1918. 
Provot, F. A.

769. A. geological reconnaissance of the Jerome district [Arizona]. 33 pp., 4 pls. (incl. map), Jerome, Arizona, May, 1916.

Pumpelly, Raphael.

770. My reminiscences. 2 vols.; 844 pp., illus., maps, New York, IIenry Holt and Company, 1918.

Purdue, A. H.

771. Manganese aeposits of Bradley County: Tennessee State Geol. Survey, Resources of Tennessee, vol. 8, no. 1, pp. 46-47, January, 1918.

Asphalt deposits and oil conditions in southwestern Arkansas. See Miser and Purdue, no. 679.

Gravel deposits of the Caddo Gap and.De Queen quadrangles, Airkansas. See Miser and Purdue, no. 680.

Quirke, Terence T.

772. The geology of the Killdeer Mountains, North Dakota: Jour. Geology, vol. 26, no. 3, pp. 255-271, 6 tigs., April-May, 1918.

Rankin, G. A., and Merwin, H. E.

773. The ternary system $\mathrm{MgO}-\mathrm{Al}_{2} \mathrm{O}_{3}-\mathrm{SiO}_{2}$ : Am. Jour. Sci., 4th ser., vol. 45, pp. 301-325, \& figs., April, 1918.

Rathbun, Mary J.

774. Decapod crustaceans from the Panama region: U. S. Nat. Mus., Bull. 103, pp. 123-184, 13 pls., 1918.

Rasmond, Percy E.

775. Report on invertebrate palaeontology: Harvard College, Mus. Conp. Zool., Ann. Rept. Director, 1917-1918, pp. 25-26, 1918.

Reeds, Chester A.

776. Fossil faunas of Porto Rico (abstract) : New York Acad. Sci., Annals, vol. 27, pp. $280-281$, November $30,1917$.

Reeside, John B., Jr.

777. The Helderberg limestone of central Pennsylvania (U. S. Geol. Survey, Prof. Paper 108-K, 1917) : Abstract, by R. W. Stone, Washington Acad. Sci., Jour., vol. 8, no. 6, p. 172, March 19, 1918.

Reger, David B., assisted by Teets, D. D., Jr.

778. Barbour and Upshur counties and western portion of Randolph County: West Virginia Geol. Survey [County Reports], ciii, 867 pp., 53 pls., 40 tigs., 4 maps, 1918.

Reid, Harry Fielding.

779. Note on the velocity of long waves and the average depth of the ocean: Seismol. Soc. America, Bull. vol. 8, no. 1, pp. 34-37, March, 191.

780. The starting point of earthquake vibrations: Seismol. Soc. America, Bull., vol. 8, nos. 2-3, pp. 79-82, 1 fig., June-September, 1918.

Reid, J. A.

781. Silver deposition and enrichment at Cobalt, Ontario (discussion):

Econ. Geology, vol. 13, no. 5, pp. 385-392, 2 tigs., July, 1918.

\section{Reinecke, L.}

782. Nonbituminous road materials: Econ. Geology, vol. 13, no. 8, pp. 557597, December, 1918. 
Rice, Marion.

783. Fetrographic notes on the ore deposits of Jerome, Arizona: An. Inst. Min. Eng., Butl. no. 141, pp. 1497-1502, .9 figs., September, $191 \mathrm{~S}$.

Rich, John L.

784. Lhe glacial phenomena of the Catskill, Mountains: New Tork state Mus. Bull. no. 196, pp. 32-39, April 1, 1917 [1918].

785. Geologic dates in physiographic descriptions: Science, new ser., vol. $4 \overline{7}$, pp. 43-44, January 11, 1918.

786. An old erosion surface in Idaho; is it Eocene? : Bcon. Geology, vol. 13, mo. 2, jp. 120-136, 1 fig., Miarch, 1918.

787. Dating of peneplains; an old :erosion surface in Taho, Montana, and Washïngton-is it Eocene? (abstract with alliscussion by Bruce L. Clark and Elït Bhackwel(er) : Geol. Soc. America, Bull., vol. 29, no. 1, pp. 89-90, March 31, 1918.

See also .Kay, no. 49.7 ; Tomlinson, no. 950 .

Richards, J. T.

Preliminary report on experiments relating to continental deformation (abstract). See Chamberlin and Richards, no. 162.

Richardson, Charles $\mathrm{H}$.

788. The Ordovician terranes of central Vermont (abstract): :Science, new ser., vol. 47, ,p. 493, May 17, $191 \mathrm{~s}$.

Rickard, T. A.

789. 'The story of the U. V. X. Bonanza [Jerome district, Arizona] : Min. and Sci. Fasss, vol. 116, ppp. 47-52, 3 tigs., January 12; 1918.

Ries, H. See Teas, no. 936.

Roark, Louis.

790. Brief notes :on field methods used an geological work of HTid-Continent oil fields: Indiana Accal. Sci., P1:oc., 1917, 1p. 235-239, 1918.

Roberts, Hugh M., and Longyear, Robert Davis.

791. Genesis of the Sulbury nickel-copper ores as indicated by, recent explorations: Am. Inst. Min. Eng., Tlatus., Nol. 59, pp. 27-56, 11 figs. (:discussion by :G. F. Kunz, F. F. Grout, W. G. Nitller, A. M. Bateman, C. P. Berkey, Waldenar Jidndgren, atud L. C. Graton, pp. 57-67), 1918; Bull. no. 134, pp. .555-584, 11 figs., February, 1918; discussion, Đoull. no. 136, 719. \$48-858, Ap1:1., 1918.

792. Exploration of nickel-copper preperties in Falconbridge township, Sudbury district, Ontario: Canadian Min. Jour., vol. 39, no. 4, .1p. 50-53, 5 figs., February 15, 1918.

7.93. Origin of Sudbury nickel-copper depesits.: Canadian Min. Jour., vol. 39, n๑. 8, pp. 135-136, April 15, 11918.

Roberts, John R., and Nash, James P.

794. The geology of Valverde County: Texas, Unir., Bull. no. 1803, 51 pp., 5 pls. (incl. map), 9 tigs., Janualy 10, 1918.

Roberts, Milnor, and others.

795. The College of Mines series of ores, coals, and useful rocks of WashBngton . . . : Washington, Univ., Bull., Gen. :Ser. : no. 110, 97 pp., April 1917. 
Robertson, Willialm I'leet.

796. Annual report on the mining industry of the Province [of British Columbia] for the year ending December 31, 1917 : British Columbia, Minister of Mines, Annual Report, 1917, 552 pp.; illus., Victoria, B. C., 1918.

Robinson, A. H. A.

797. Investigation of iron ores: Canada, Dept. Mines, Mines Branch, Summ. Rept., 1917, pp. 11-22, map, 1918.

Rogers, Austin F.

798. The occurrence of cristobalite in California: Am. Jour. Sci., 4th ser., vol. 45, pp. 222-226, March, 1918.

799. An American occulrence of periclase and its bearing on the origin ant history of calcite-brucite rocks: Am. Jour. Sci., 4th ser., vol. 4t, pp. 581-586, 2 figs., October, $191 \mathrm{~s}$.

Rogers, G. Sherburne.

800. Relation of sulphur to variation in the gravity of California petroleum : Am. 'Inst. Min. Eng., Trans., rol. 57, pp. 989-1005, 4 figs. (with discussion by C. W. Washburne, Clifford Richardson, and C. F. Mabery, pp. 1005-1009), 1.918.

801. Principles and problems of oil prospecting in the Gulf coast country (discussion) : Am. Inst. Ain. Eng., Bull. no. 136, pp. \$24-829, April, 1918 ; no. 140, pp. 1163-1164, August, 1918.

802. The petrology of reservoir rocks and its influence on the accumulation of petroleum (discussion): Econ. Geology, vol. 13, no. 4, pp. 316-324, June, 1918.

803. Intrusive origin of the Gulf coast salt domes: Econ. Geology, vol: 13, no. 6 , pp. $447-485,4$ pls., 2 figs., September, 191.8 .

804. Possible existence of deep-seated oil deposits on the Gulf coast (discussion ) : Am. Inst. Min. Eng., Bull. no. 142, pp. 1558-1560, October, 1.918 .

See also Matteson, no. 634 .

Rolfe, Frank, and Strong, A. M.

805. The earthquake of April 21, 1918, in the San Jacinto Mountains ICalifornia] : Seismol. Soc. America, Bull., vol. 8, nos. 2-3, pp. 63-67, June-September, 1918.

Romberg, Arnold.

An experiment in teleseismic registration. See Jaggar and Romberg, no. 470 .

Rose, B.

806. Crowsnest and Flathead coal areas, British Columbia: Canada Geol. Survey, Summ. Rept., 1917, pt. C, pp. 28-35, 1918.

Ross, Clarence S.

807. Structure and oil and gas resources of the Osage Reservation. Oklahoma ; Tps. 20 and 21 N., R. 12 E.: U. S. Geol. Survey. Bull. 686, pp. 171-178, 2 pls. (incl. map), 2 figs., 191.8.

Ruedemann, Rudolph.

808. The paleontology of arrested evolution: New rork state Mus. Bull, no. 1.96, pp. 107-1.34, April 1, 1917 [.1.91S].

809. The phylogeny of the acorn barnacles: Nat. Acad. Sci., Proc. vol. 4, no. 12 , pp. 382-384, 1 pl., December, 1918. 
Runner, J. J., and Hartmann, M. L.

810. The occurrence, chenistry, metallurgy, and uses. of tungsten, with speciall reference to the Black Hills of South Dakota: South Dakota School of Mines, Bull. no. 12, pp. 4-159, 11 pls., 2 figs., September, 1918.

Salisbury, Rollin D.

811. The American Association for the Advancement of Science; Section E, Geology and Geography [proceedings sixty-ninth meeting in Pittsburgh, December 28 and 29, 1917]: Science, new ser., vol. 47, pp. 467-470, 492-494, May 10 and 17, 1918.

812. Geology in education: Science, new ser., vol. 47, pp. 325-335, April 5, 1918.

Salisbury, Rollin D., and Barrows, Harlan $\mathrm{H}$.

813. The environment of Camp Grant: Illinois state Geol. Survey, Bull. no. 39,75 pp., 2 pls., 25 figs., 1918.

Salkover, B.

Note on the inorganic constituents of two small crustacenns. See Clarke and Salkover, no. 180.

Sapper, Karl.

814. Geschwistervulkane in Guatemala: Zeitschr. Vulkanologie, Bd. 4, H. 1, pp. 1-14, 10 pls. (incl. map), Ápril, 1918.

815. Tätigkeit des Lassen Peak in den Jahren 1914 und 1915 bis Anfang 1916: Zeitschr. Vulkanologie, Bd. 4, H. 1, pp. 51-52, April, 1918.

Savage, T. E.

816. Correlation of the early Silurian rocks in the Hudson Bay region: Jour. Geology, vol. 26, no. 4, pp. 334-340, 1 fig., May-June, 1918.

817. Tentative correlation of the Pennsylvanian strata in the eastern interio:, western interior, and Appalachian regions by their marine faunas (abstract) : Geol. Soc. America, Bull., vol. 29, no. 1, p. 97, March 31, 1918.

Savage, T. E., and Crooks, H. F.

818. Early Silurian rocks of the northern Peninsula of Michigan: Am. Jour. Sci., 4th ser., vol. 45, pp. 59-64, January, 1918.

Sayles, Robert W.

819. A naturalistic model of Kilauea Volcano, Hawaii: Geog. Rev., vol. 5, no. 1, pp. 38-43, 3 figs., January, 1918.

820. Report on the geological collection: Harvard College, Mus. Comp. Zool., Ann. Rept. Director, 1917-1918, p. 27, 1918.

Schaller, Waldemar T.

821. Zirconium and rare-earth minerals: Mineral Foote-Notes vol. 2, no. 3, pp. 2-14, March, 1918.

822. Gems and precious stones in 1916: U. S. Geol. Survey, Mineral Resources, 1916, pt. 2, pp. S87-899, June 27, 1918.

823. Gems and precious stones in 1917: U. S. Geol. Survey, Mineral Rë sources, 1917 , pt. 2 , pp. 145-168, July $29,1918$.

824. Mica in 1917: U. S. Geol. Survey, Mineral Resources, 1917, pt. 2, pp. 183-195, July 29, 1918.

Schofield, S. J.

825. The late Captain Osmond Edgar LeRoy: Canadian Min. Inst., Mo. Bull., no 70, pp. 149-155, February, 1.918. 
Schrader, Frauli C.

826. Quicksilver deposits of the Phoenix Mountains, Arizona: U. S. Geol. Survey, Bull. 690, pp. 95-109, 4 tigs., Junè 26, 1918. Abstract, by R. W. Stone, Washington Acad. Sci., Jour., vol. 8, no. 15, p. 538, - september 19, 1.918.

Manganese deposits of east Tennessee. See Stose and Schrader, no. 923.

Schuchert, Charles.

827. The enrth's changing surface and climate during geologic time. In The evolution of: the earth and its inhabitants [edited by $\mathbf{R}$. S. Luill], pp. 45-81, 11 figs., New Haven, Yale University Press, 1918.

828. On the Carboniferous of the Grand Canyon of Arizona: Am. Jour., Sci., 4th ser., vol. 45, pp. 347-361, 5 figs., May, 1918.

829. The Cambrian of the Grand Canyon of Arizona: Am. Jour. Sci., 4th ser., vol. 45, pp. 362-369, 2 figs., May, 1918.

830. Age of the American Morrison and east African Tendaguru.formations: Geol. Soc. America, Bull., vol. 29, no. 2, pp. 245-280, June 30, 1918.

831. A century of geology; the progress of historical geology in North America: Am. Jour. Sci., 4th ser., vol. 46, pp. 45-103, 1918. Reprinted in A century of science in America, pp. 60-121, New Haven, 1918.

832. Henry Shaler Williams; an appreciation of his work in stratigraphy: Am. Jour. Sci., 4th ser., vol. 46, pp. 682-687, November, 1918.

Schultz, Alfred Reginald.

833. A geologic reconnaissance for phosphate and coal in southeastem Idaho and western Wyoming: U. S. Geol. Survey, Bull. 680," $" \ddot{4}$ pp., $\ddot{2}$ pls., 8 tigs. (incl. maps), 1918.

834. A geologic reconnaissance of the Uinta Mountains, northern "Utah, with special reference to phosphate: U. S. Geol. Survey; Bull. 690, pp. 31-94, 2 pls. (maps), 1 fig., May 10, 1918. Abstract, 'by R. W. Stone, Washington Acad. Sci., Jour., vol. 8, no. 13, np. 453-454, July 19, 1918.

Schwennesen, A. T.

835. Ground water in San Simon Valley, Arizona and New Mexico (U. S. Geol. Survey, Water-Supply Paper 425-A, 1917): Abstract, by O. E. Meinzer, Washington Acad. Sci., Jour., vol. 8, no. 5, p. 128 , Narch 4, 1918.

836. Ground water in the Animas, Playas, Hachita, and San Luis basins, New Mexico: U. S. Geol. Survey, Water-Supply Paper 422, 1.52 pp., 9 pls. (incl. maps), 17 figs., 1918.

Schwennesen, A. T., and Meinzer, O. E.

837. Ground water in Quincy Valley, Washington: U. S. Geol. Survey, WaterSupply Paper 425, pp. 131-161, 2 pls., 3 tigs., December 30, 1918.

Scott, George S.

838. Iridescent quartz from New York City: Am. Mineralogist, vol. 3, no. 10, p. 183, October, 1918.

Sellards, E. H.

839. Tenth and eleventh annual reports. Florida State Geol. Survey, $130 \mathrm{pp}$., 4 pls., 9 figs., Tallahassee, 1.918.

840. The skull of a Pleistocene tapil including description of a new species and a note on the associated famna and flori: Florida State Geol. Survey, 10th and 11th Ann. Repts., pp. 57-70, 3 pls., 1918. 
Sellards, E. H.-Continued.

841. Statistics on mineral production in Florila during 1917: Florida State Geol. Survey, 10th and 11th Ann. Tiepts., pp. 103-110;:1918.

Sellards, E. H., and Gunter, H. sous, ia

842. Geology between the Apalachicola and Ocklocknee rivers in Florida: Florida State Geol. Survey, 10th and 11th Ann. Repts., Pr. 9-56, 6 iigs., map, 1918.

843. Geology between the Choctawhatchee and Apalachicola rivers in Florida: Florida State Geol. Survey, 10th and 11th Ann. Repts., pp. 77-102, 2 figs., man, 1918.

Sellier, L. M.

844. Preliminary [ฉeologic] map of Kentucky. Scale 1 inch to 10 miles. Tientucky Geol. Survey, 1917.

Semmes, D. R.

845. Geology of the San Juan district, Porto Rico (abstract) : New York Acad. Sci., Annals, vol, 27, pp. 279-280, November 30, 1917.

Shannon, Earl V.

846. On mullanite, a new member of the jamesonite group from two localities: Am. Jour. Sci., 4th ser., vol. 45, pp. 66-70, 2 figs., January, 1918.

847. On the occurrence of ilvaite in the South Mountain district, Owyhee County, Idaho: Am. Jour. Sci., 4th ser., vol. 45, pp. 11S-125, 6 figs., February; 1918.

848. Some minerals from the Stanley antimony mine, Idaho: Am. Mineralogist, vol. 3, no. 3, pp. 23-27, March, 1918.

Shaw, Eugene Wesley.

849. Significance of sorting in sedimentary rocks: Geol. Soc. America, Bull. rol. 28 , no. 4 , pp. 925-982, December $19,1917$.

850. The Pliocene history of northern and central Mississippi: U. S. Geol. Survey, Prof. Paper 108, pp. 125-163, 16 pls., 5 figs., February $15,1918$.

851. The "Jakes" of northeastern Arkansas and some features of the work of the Mississipni River (abstract) : Washington Acal. Sci., Jour., vol. 8, no. 4, pp. 99-101, February 19, 1918.

852. Crevices and cavities in oil sands (discussion) : Econ. Geology, vol. 13, no. 3, pp. 207-222, May, 1918.

853. Characteristics of the upper part of the till of southern Illinois and elsewhere (abstract) : Geol. Soc. America, Bull., vol. 29, no. 1, p. 76 , March 31,1918 .

854. Relation between occurrence and quality of petroleum and broad areas of uplift and folding (abstract): Geol. Soc. America, Bull., vol. 29, no. 1, pp. 87-88, March 31, 1918.

855. Principles and problems of oil prospecting in the Gulf coast country (discussion): Am. Inst. Min. Eng., Bull. no. 136, pp. 829-830, April, 1918.

856. Ages of peneplains of the Appalachian. Province: Geol. Soc. America, Bull. vol. 29, no. 3, pp. 575-586, September 30, 1918.

857. Anomalous dips: Econ. Geology, vol. 13, no. 8, pp. 598-610, Decenber, 1918.

See also Matteson, no. 634. 
Shearer, Harold Kurtz.

858. Report on the slate deposits of Georgia: Georgia Geol. Survey, Bull. $\therefore$.. no. 34, 192 pp., 13 pls., 8 tigs., 3 maps, 191.S.

Deposits of: Claiborne and Jackson age in Georgia. See Cooke anl

mis... Shearer, no. 206.

Shearer, H. K., and Hull, .T. P. D.

859. A preliminary report on a part of the pyrites deposits of Georgia: Georgia Geol. Survey, Bull. no. 33, 229 pp., 9 pls., 1 map, 20 figs., 1918.

Shepard, Edward M.

860. Geology of Greene County [Missouri]: In Fairbanks, Jonathan, and Tuck, Clyde Edwin, The history of Greene County, Missouri, vol. 1, pp. 59-119, Indianapolis; A. W. Bowen and Co., 1915.

Shideler, W. H.

861. A primitive type of Agelacrinites from the Richmond: Ohio Jour. Sci., vol. 19, no. 1, p. 5S, November, 1.91.S.

Shimer, Hervey W.

862. Postglacial history of Boston: Am. Acal. Arts and Sçiences, vol. 63 , no. 6 , pp. 441-463, 1 fig., May, 191 .

Shufelt, Robert Wilson.

863. Notes on some bird fossils from Florida: The Auk, vol. 35, no. 3, pl. (a) 357-35S, July, 191.S.

Shuler, Fllis $\mathrm{W}$.

864. The geology of Camp Bowie and vicinity: Texas, Cniv., Bull, no. 1750. 14 pp., 2 pls., September 5, 1917.

Siebenthal, C. E.

865. Calmium in 1917: U. S. Geol. Survey, Mineral Resources, 1917, it. i, pp. 49-53, July 12, 1.91.S.

Sieplein, O. J.

866. The change of content of gasoline vapor in natural gas with age of the wells (abstract): Science, new ser., vol. 47, pp. 494, Mray $17,1918$.

Sigg, Henri.

Sur quelques roches éruptives de la Caroline du Norl. See Iageon and Sigg, no. 596.

Sinclair, W. T.

867. A large parasuchian from the Triassic of Pennsylvania : Am. Tour. Sci., 4th ser., vol, 45 , pp. $457-462$, 10 figs., June, $191 \mathrm{~s}$.

Singewald, Joseph T., jr.

868. Concentration experiments, with the siliceons red hematite of the Birmingham district, Alabama: U. S. Bur. Mines, Bull. 110, 91 p)., 47 figs., map, 1917.

See also Emmons, no. 292.

Skeats, Ernest. W.

869. The formation of dolomite and its hearing on the coral reef problem: Am. Jour., Sci., 4th ser., vol. 45, pp. 185-200, March, 1918.

Slipper, S. E.

870. Oil production, Sheep River area [Alberta]: Canada Geol. Survey, Summ. Rept., 1917, pt. C, pp. 4-5, 1.918. 
Slipper, S. E.-Continued.

871. Viking gas field [central-Alberta]; structure of area: Canada Geol. Survey, Summ. Rept., 1917, Pt. C, pp. 6-9, 1 pl., 1918

Smith, Eugene Allen.

$6 . \mathrm{H}$ in inte.

872. Memorial of Robert Hills Loughridge: Geol. Soc. America, Bull., vol. 29, no. 1, pp. 48-55, port., March 31, 1918.

Smith, George Otis.

873. Geology and the public service: New York State Mus. Bull. no. 196, pp. 135-144, April 1, 1917 [1918].

874. Thirty-ninth annual report of the Director of the United States Geological Survey to the Secretary of the Interior for the fiscal year encled June 30, 1918. 163 pp., 4 pls., Washington, 1918.

875. A century of government geological surveys: Am. Jour., Sci., 4th ser., vol. 46, pp. 171-192, July, 1918. Reprinted in A century of science in America, pp 193-216, New Haven, 1918.

876. The economic limits to domestic independence in minerals: U. S. Geol. Survey, Mineral Resources, 1917, pt. 1, pp. 1a-6a, December 28, 1918.

876a. Our mineral reserves. In American problems of reconstruction, edited by Elisha M. Friedman, pp. 59-87, New York, E. P. Dutton \& Company, 1918.

Smith, J. P.

877. Tropitidae of the upper Triassic of California (abstract): Geol. Soc. America, Bull., vol, 29 , no. 1 , p. 162 , March $31,1918$.

Smith, Philip S.

878. The Lake Clark-central Kuskokwim region, Alaska: U. S. Geol. -Survey Bull. 655, 162 pp., 12 pls. (incl. maps), 6 figs., 1917. Abstratet, Washington Acad. Sci., Jour., vol. 8, no. 13, p. 453, July 19, 1918.

s79. Sulphur. pyrite, and sulphuric acid in 1916: U. S. Geol. Survey, Mineral Resources, 1916, pt. 2, pp. 403-432, January 23, 1918.

880. Sulphur, pyrites, and sulphuric acid in 1917 : U. S. Geol. Survey, Mineral Resources, 1917, pt. 2, pp. 19-62, July 10, 1918.

881. The geologist in war times; the United States Geological Survey's war work (discussion) : Econ. Geology, vol, 13, no. 5, pp. 392-399, July, 1918.

882. Sulphur in Jemez Canyon, New Mexico: Eng. and Min. Jour., vol. 106, j. 449 , September 7 , 1918. [In error attributed to Fhilip S. Smith. See Mansfield, G. R., no. 61Sa.]

Smith, Warren Du Pré.

883. Guide to Condon Geological Museum, University of Oregon: Oregon, Univ., Pub., new ser., vol. 1, no. 3, 26 pp., 1 pl., September, 1916.

884. A summary of the salient features of the geology of the Oregon Cascades, with some correlations between the geology of the east coast of Asia and that of the west coast of America: Oregon, Univ., Bull., new ser., vol. 14, no. 16, 54 pp., 1 pl., 2 tigs., December, 1917.

885. Salient features of the geology of the Cascades of Oregon, with some correlations between the east coast of Asia and the west coast of: America (abstract) : Geol. Soc. America, Buil., vol. 29, no. 1, p. 81, March 31, 1918.

886. The Wallowa Mountains [Oregon]-; geology and economic geography:

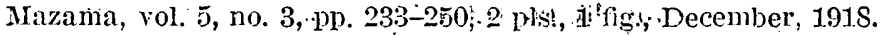




\section{Smithsonian Institution.}

886a. Explorations and field work of the Smithsonian Institution in 1917:

Słnithsonian Misc. Coll., vol. 68, no. 12, 133 pp., 137 figs., June, 1918.

Smyth, C. H., Jr .

887. Genesf of the zinc ores of the Edwards district, St. Lawrence County,

New York; New York State Mus. Bull, no. 201, 41 pp., 12 pls., 1918. Lake Bonaparte quadrangle. See Buddington and Smyth, no. 1.18.

Snider, L. C.

888. Geography of Oklahoma: Oklahoma Geol. Survey, Bull. no. 27, 325 pp., 40 pls. (incl. maps), 9 figs., September, 1917.

Soper, E. K.

889. Mining districts of northern Idaho: Min. and Sci. Press, vol. 116, pp. 121-127, 3 figs., January 26, 1918.

Sosman, R. B.

890. The work of the geophysical laboratory of the Carnegie Institution of Washington: Am. Jour. Sci., 4th ser., vol. 46, pp. 255-258, July, 1918. Reprinted in A century of science in America; pp. 284-287, New Haven, 1898.

Sosman, R. B., and Hostetter, J. C.

891. Zonal growth in henatite and its bearing on the origin of certain iron .2 ores: Am. Inst. Min. Eng., Trans., vol. 5S, pp. 434-444, 3 figs., 191. Abstract, Washington Acad. Sci., Jour., vol. 8, no. 10, p. 329, May 19, 1918.

Spence, Harold C. E.

892: The oil shales of Pictou, Cape Breton: Canadian Min. Inst., Monthly Bull., no. 79, pp. 928-931, 1 fig., November, 1918.

Spence, Hugh S:

893. The Canadian graphite industry: Canada, Dept. Mines, Mines Branch, Summ. Rept. 1917, pp. 49-50, 1918.

Spencer, Arthur C.

894. The geology and ore deposits at Ely, Nevada: U. S. Geol, Survey, Prof. Paper 96, 1917. Review by C. H. Clapp", Econ. Geology, vol. 13, no. 5, pp. 400-409, July, 1918.

895. The geology and ore deposits of Ely, Nevada (U. S. Geol. Survey, Prof. Paper 96, 1917) : Abstract, by John B. Hastings, Min. and Sci. Press, yol. 116, pp. 857-862, 2 tigs., June 22, 1918. Abstract, by R. W. Stone, Washington Acad. Sci., Jour., vól. 8, no. 13, pp. 455456, July 19, 1918.

Geology of Cuba ; a reprint of the chapters, on physiograpihy and general geology from the "Report on a geological reconnaissance of Cuba," partly revised by Pablo Ortega. See Hayes and others, no. 421.

Spilsbury, E. G.

896. Manganiferous iron ores of the Cuyunil district, Minnesota (discussion [manganese in Costa Rica]) : Am. Inst. Min. Eng., Bull. no. 133, p. 103, Januạry, 1918.

Springer, Frank.

897. On Mysticoctinus, a new genus of Silurian Crinoiden: 4 th ser., vol, 46 , pp. 666-668, 1 pl., November, 1918, is $\therefore$ 
Spurr, J. IE.

898. War minerals: Econ. Geology, vol. 13, no. 7, nn. 500-511, November, 1918.

Stansfield, Erlgar, ant Nicolls, J. H. H.

899. Analyses of Canadian fuels; in five parts: Canada, Dept: Mines, Mines Branch, 1918. Part 1, The maritime provinces, Bull. no. 22, 28 pp.; Part II, Quebec and Ontario, Bull, no. 23, 25 pp.; Part III, Manitoba and Saskatchewan, Bull. no. 24, 15 pp.; Part IV, Alberta and the Northwest territories, Bull, no. 25, 68 pp.; Part $\nabla$, British Columbia and Yukon Territory, Bull. no. 26, 24 pp.

Stansfield, J.

900. Surface deposits of southwestern Saskatchewan: Canada Geol. Survev, Summ. Rept., 1917, pt. C, pp. 41-52, 1 fig., 1918.

901. Concentric ridges on naturally occurring silica: Roy. Soc. Canarla, Trans., 3d: ser., vol. 11, sec: 4, pp. 117-120, 1 pl., 191.S.

Stanton, Gilman S.

902. Louis Pope Gratacap: Am. Mineralogist, vol. 3, no. 4, pp. 31-33, port. (in no. 5), April, 191S.

Stauffer, Clinton R.

903. Descriptions of some new species of Devonian fossils: Jour. Geology, vol. 26 , no. 6 , pp. $5 \overline{5} \overline{0}-560,3$ pls., September-October, $191 \mathrm{~s}$.

Staunton, W. F.

904. Effects of an earthquake in a mine at Tombstonc, Arizona : Seismol. Soc. America, Bull., vol. 8, no. 1, pp. 25-27, March, 1918.

Stebinger, Eugene.

905. Oil and gas geology of the Birch Creek-Sun River area, northwestern MIontana: U. S. Geol. Survey, Bull. 691, pp. 149-18t, 1 pl. (uap), 3 figs., August 13, 1918.

Steidtmann, Edward.

906. The origin of petroleum pools: Jour. Geography, vol. 16, no. 8, pn. 310-313, April, 1918.

Steiger, George.

Fluorine in sericitization. See Paige and Steiger, no. 723.

Titanium-bearing corundum spinellite (rock emery); a preliminary statement of its occurrence and composition in Virginia. See Watson and Steiger, no. 1008.

Stephenson, Lloyd William:

907. Fort Momroe, Langley Field, and the adjacent country [Virginia]. [Text on back of topographic map], Virginia, Hampton quadrangle, Langley Field, U. S. Geol. Survey, 1918.

908. The camps around Sin Antonio [Texas]. [Text on back of topographic map], Texas, San Antonio quadrangle, Kelly Fields and Camp Travis, U. S. Geòl. Survey, 1918.

909. A contribution to the geology of northeastern Texas and southern Oklahoma: U. S. Geol. Survey, Prof. Paper 120, pp. 129-163, 14 pls. (incl. map), November 22, 1918.

Stephenson, L. W., and Miser, H. D.

910. Camp Pike and the adjicent country [Arkảnsas]. [Text on back of topographic map], Arkansas, Iittle Rock quadrangle, Camp Pike, U.: S. Geol. Survey, 1918. 
Sternberg, Charles H.

911. Five year's' explorations in the fossil beds of Alberta: Kansas Acad. Sci., Trans., vol. 2S, pp. 205-211, 1918.

Sterrett, D. B.

in : Tin resources of the Kings Mountain district, North Carolina and South Carolina. See Keith and Sterrett, no. 499.

Stevens, Blamey.

912. The mechanics of vein formation (discussion): Am. Inst. Min. Eng., Bull. no. 144, pp. 1768-1770, December, 1918.

\section{Stevenson, John J.}

913. Interrelations of the fossil fuels, III : Am. Philos. Soc., Proc., vol. 57, no. 1, pp. 1-48, 1918.

Stiles, (Miss) M. E.

914. Bureau of economic geology and technology; annual report for the year ending December 31, 1915: Texas, Univ., Bull., 1916, no. 35, pp. 5-16, 1 pl., June 20, 1916.

Stock, Chester.

915. Minutes of the eighth annual meeting of the Pacific coast section of the Paleontological Society: Geol. Soc. America, Bull., vol. 29, no. 1, pp. 160-166, March 31, 1918.

916. Gravigrade edentates in later Tertiary deposits of North America (abstract) : Geol. Soc. America, Bull., vol. 29, no. 1., pp. 161-162,

\section{.ं. March 31, 1918.}

917. The Pleistocene fauna of Hawver Cave: California Univ., Dept. Geology, Bull., vol. 10, no. 24, pp. 461-515, 32 figs., April 23, 1918.

Stone, Ralph W.

918. The development of valuable magnesite deposits in the State of Washington (abstract): Washington Acad. Sci., Jour., vol. 8, no. 4, p. 99, February 19, 1918.

919. Magnesite deposits of Washington: Eng. and Min. Jour., vol. 105, pp. 665-668, 5 figs., April 13, 1918.

920. Phosphate rock in 1917 , with notes on phosphorus: U. S. Geol. Survey, Mineral Resources, 1917, pt. 2, pp. 7-18, June 25, 1918.

921. Gypsum in 1917: U. S. Geol. Survey, Mineral Resources, 1917, pt. 2, pp. 85-95, July 11, 1918.

922. Salt, bromine, and calcium chloride in 1917: U. S. Geol. Survey, Mineral Resources, 1917, pt. 2, pp. 169-181, August 10, 1918.

Magnesite in 1917. , See Yale and Stone, no. 1085.

See also Ashley, no. 23 ; Beal, no: 57 ; Bowen, no. 87; Bowles, no. 96 ; Collier, no. 197; Collier and Thom, no. 201; Darton, no. 227; Eakin, no. 275 ; Emerson, no. 283 ; English, no. 294 ; Fath, no. 302 ; Gregory, no. 366 ; Harder and Johnston, no. 402 ; Heald, no. 424; Hewett and Lupton, no. 432 ; Hewett and others, no. 433 ; Hopkins, no. 452, 453; Keith and Sterrett, no. 499; Loughlin, no. 591; Matson, no. 630; Matson and Hopkins, no. 631, 632; Mertie, no. 668 ; Miser and Purdue, no. 680 ; Pardee, no. 739 ; Reeside, no. 777 ; Schrader, no. 826 ; Schultz, no. 834 ; Spencer, no. 895; Wegemann, no. 1010 ; Wells, no. 1015; Winchester, no. 1065.

Stose, G. W.

Possibilities for manganese ore on certain undeveloped tracts in Shenandoah Valley, Virginia. See Hewett and others, no. 433. 
Stose, G. W., and Schrader, F. C.

923. Manganese deposits of east Tennessee: Tennessee State G, Gol. Survey, Resources of Tennessee, vol. 8, no. 3, pp. 153-207,.j0 figs., July, 1918; no. 4, pp. 228-324, 1 fig., 4 maps, October, 1918.

Strong, A. M.

The earthquakè of April 21, 191.8, in the San Jacinto Mountains [Calfornial. See Rolfe and Strong, no. 805.

Taber, Stephen.

924. The genesis of asbestos and asbestiform minerals: Am. Inst. Min. Eng., Trans., vol. 57, pp. 62-87, 7 figs. (with discussion by J. C. Branner, J. A. Dresser, R. P. D. Graham, G. P. Merrill, and the author, pp. S7-98), 1918.

925. Pressure in the formation of ore deposits: Min. and Sci. Press, vol. 116, pp. 1.28-130, 3 figs., January 26, 1918.

926. The origin of the veinlets in the Silurian and Devonian strata of central

New York: Jour. Geology, vol. 26, no. 1, pp. 56-73, 6 tigs., JanuaryFebruary, 1918.

827. The mechanics of vein formation: Am. Inst. Min. Eng., Bull. no. 140, pp. 1189-1222, 5 tigs., August, 1918. Discussion by Blamey Stèvens, Bull. no. 144, pp. 1768-1770, December, 1918.

Taft, H. H.

928. A Wyowing platinum mine: Eng. and Min. Jour., vol.: 106, p. 900, November 23, 1918.

Taliaferro, N. '́.

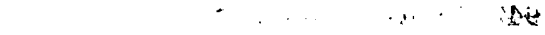

Anticlines near Sunshine, Park County, Wyoming. Seè Moody and Taliaferro, no. 688.

Tarr, William Arthur.

929. Genesis of Missouri lead and zinc deposits (abstract, with discussion by W. H. Emmons, F. R. Van Horn, and H. A. Whieeler) : 'Geol. Soc. America, Bull. vol. 29, no. 1, pp. 86-87, March 31, 1918.

930. Siliceous oolites in shale (abstract): Geol. Soc. America, Bull., vol. 29, no. 1, pp. 103, 104, March 31, 1918.

831. Glauconite in dolomite and limestone of Missouri (abstract) : Geol. Soc. America, Bull., vol. 29, no. 1, p. 104, March 31, 1918.

932. The barite deposits of Missouri and the geology of the barite district: Missouri, Univ., Studies, vol. 3, no. 1, 111 pp., 10 pls. (incl. map), September, 1918.

933. Oolites in shale and their origin: Geol. Soc. America, Bull., rol. 29, no. 3, pp. 5ST-600, 2 pls., 2 figs., September 30 , 191.s.

924. Rhythmic banding of manganese dioxide in rhyolite tuff: Jour. Geology, vol.. 26, no. 7, pp. 610-617,. 2 figs., October-November, 1918.

See also Bagg, no. 29.

Taylor, Joseph $\mathrm{H}$.

935. Pyrite and pyrhotite resources of Ducktown, Tennessee: A.m. Inst. Min. Eng., Bull. no. 134, pp. 529-533, February, 1918; Trans., vol. 59, pp. \&s-92, 1918.

Teas, L. P.

936. The relation of sphalerite to other sulphides in ores: Am. Inst. Min. Eng., Trans., vol. 59, pp. 68-82, 14 tigs. (aliscussion by 'T. L. Watson, L. C. Graton, and H. IRies, pp. \$3-\$7), 1918. 
Teets, D. D., Ji.

Barbour and Upshur counties and western portion of Randolph County.

Thayer, w. II.

see Reger and Teets, no. 778.

937. The northward extension of the physiographic divisions of the United States : Jour: Geology; vol. 26, no. 2, pp. 161-7.85, no. 3, pp. 237-254, 2 figs., 1918 .

938. The Kentucky oil tields: Eng. and Min. Jour., vol. 105, pp. 781-785, 2 tigs., April 27, 1918.

Thiessen, Reinhardt.

939. The determination of the stratigraphic position of coal seams by means of their spore-exines (abstract): Science, new ser., vol. 47, p. 469, May 10, 1918.

Thom, W. T., Jr.

The Flaxville gravel and its relation to other terrace gravels of the northern Great Plains. See Collier and Thom, no. 201.

Thomas, Kirby.

940. Principles and problems of oil prospecting in the Guif coast country (discussion): Am. Inst. Min. Eng., Bull. no. 136, pp. 832-833, April, 1918.

941. Saline domes and other salt deposits: Min. and Sci. Press., vol. 117, $\because$. p. 226, August 17, 1918 .

942. Sulphur deposits in the trans-Pecos region in Texas: Fing. and Min. Jour., vol. 106, pp. 979-9S1., 3 tigs., December 7 , 1918.

See also Matteson, no. 634 .

Thomson, Ellis.

943. Dryden gold area : Ontario Bur. Mines, 26th Ann. Rept., 1917, vol. 26, pp. 163-189, 20 figs., map, 1.91.7.

944. A pegmatitic origin for wolybdenite ores: dcon. Geology, vol. 1.3, no. 4, pp. 302-313, 2 pls., Tune, 1918.

945. Some Canalian cerusite crystals: Am. Mineralogist, vol. 3, no. 5, pp. 41-43, 2 figs., May, 1918.

Tibby, Benjamin F.

946. The East IIintic listrict, Utalı: Min. and Sci. Press., vol. 116, pp. 341.342, 2 .tigs., March 9, 191.8.

Todd, J. E.

947. Kansas during the ice age: Kansas Acal. Sci., Trans, vol. 2\$, pp. 32-47, 1. pl. (map), 1918.

948. History of Kaw Lake [Kansas]: Kansas Acad. Sci., Trans., vol. 28, pp. 1.87-199, 3 figs., 191.8 .

949. Eolian loess: Kansas Acad. Sci., Trans., vol. 28, pp. 200-208, 1918.

See also Crook, no. 212 ; Kay, no. 497.

Tomlinson, C. W.

950. Present status of the problem of the origin of loess (abstract, with discussion by Frank Leverett, J. T. Rich, A. R. Crook, T. H. Lees, and W. H. Bucher): Geol. Soc. America, Bull., vol. 29, no. 1, pp. 73-74, March 31, 191.s.

Tovote, IV.

95i. Cunningham Pass district, Arizona: Min. and Sci. Press, vol. 11.7, pp. 19-20, 2 tigs.," July 6 , 191.8. 
Tovote, W.-Continued.

952. Notes on certain ore deposits of the Southwest: Am. Inst. Min. Eng., Bull. no. 142, pp. 1599-1612, October, 191.S.

Townley, S. D.

- Ifi; 4 ....

953. The San Jacinto [California] earthquake of April 21, 1918: Seismol. Soc. America, Bull., vol. 8, nos. 2-3, pp. 45-62, 8 pls., 1 fig., JuneSeptember, 1918.

Trudell, Harry W.

954. Famous mineral localities; 2, The gem regions of North Carolina: Am. Mineralogist, vol. 3, no. 2, pp. 14-17, l'ebruary, 1918.

Trumbull, L. W.

955. Light-oil fields of Wyoming: Wyoming, Geologist's Office, Bull. no. 12 (2d edition), pp. 123-134, 2 maps, 1917.

Tucker, W. Burling. See Bradley and others, no. 100.

Twenhofel, W. H.

956. The Comanchean of central Kansas: Kansas Acad. Sci., Trans., vol. 2S, pp. 213-223, 1 fig., 1918.

Tyrrell, J. B.

957. Northern Mauitoba as a mining country. In Northern Manitoba, pp. $23-$ 25, issued by the Province of Manitoba, November, 1917.

Udden, J. A.

958. Geological maps in Texas: Texas, Univ., Bull., 1916, no. 35, pp. 1\%-21, 1 pl. (map), June 20, 1916.

959. Notes on the geology of Glass Mountain: Texas, Univ., Bull. no. 1753, pp. 3-59, 3 pls. (map and sections), september 20, 1917 .

960. Funnel and anticlinal ring structure associated with igneous intrusions in the Mexican oil field (discussion) : Am. Inst. Min. Eng., Bull. no. 133, pp. 93-95, January, 1918.

961. The theory of volcanic origin of salt domes (discussion): Am. Inst. Min. Eng., Bull. no. 139, p. 1147, July, 1918.

Ulrich, E. 0 .

962. The formations of the Chester series in western Kentucky and their correlates elsewhere: Kentucky Geol. Survey, Mississippian formations of western Kentucky, 272 pp., pls. and tables, Frankfort, 1917.

963. Clinton formations in the Anticosti section (abstract): Geol. Soc. America, Bull., vol. 29, no. 1, p. 82, March 31, 1918.

\section{Umpleby, Joseph B.}

964. Arsenic, bismuth, selenium, and tellurium in 1916: U. S. Geol. Survey, Mineral Resources, 1916, pt. 1, pp. 501-505, February 2, 1918.

965. Arsenic, bismuth, selenium, and tellurium in 1917: U. S. Geol. Survev, Mineral Resources, 1917, pt. 1, pp. 23-35, June 19, 1918.

\section{United States Geological Survey.}

965a: The country around Camp Grant [Illinois]. . [Text on back of topographic map], Illinois, Camp Grant quadrangle, U. S. Geol. Survey, 1918.

Van der Gracht, W.

966. Geosynclines and petroliferous deposits (discussion): Am. Inst. Min. Eng., Bull. no. 133, pp. 97-99, January, 1918. 
Van Horn, Frank R.

967. Occurrence of a large tourmaline in Alabama pegmatite (abstract): Geol. Soc. America, Bull. vol. 29, no. 1, pp. 104-105, March 31, 1918.

See also Tarr, no. 929 ; White, no. 1035.

Van Ingen, Gilbert.

968. Directions for preparing a report on the geology of a region; for the use of students in the department of geology of Princeton University. 19 pp., published by Gilbert van Ingen, Frinceton, N. J., 1916.

Van Mater, J. A.

969. Pyrrhotite deposits of southwest Virginia: Eng. and Min. Jour., vol. 105, pp. 198-199, 1 fig., January 26, 1918.

Van Orstrand, C. E.

970. Apparatus for the measurement of temperatures in deep wells and temperature determinations in some deep wells in Pennsylvania and West Virginia: West Virginia Geol. Survey, Barbour and Upshur counties, pp. lxvi-ciii, 6 pls., 15 figs., 1918.

Van Tuyl, Francis M.

971. The origin of chert: Am. Jour. Sci., 4th ser., vol. '45, pp. 449-456, June, 1918.

972. The depth of dolomitization: Science, new ser., vol. 48, pp. 350-352, October 4 , 1918 .

Van Tuyl, Francis M., and Crooks, Harold F.

973. Types of North American Paleozoic oolites (abstract) : Geol. Soc. America, Bull. vol. 29, no. 1, p. 102, March 31, 1918.

Van Winkle, Katherine E. H.

974. Haleontology of the Oligocene of the Chehalis Valley, Washington:

pr. . Washington, Univ., Pub. in Geology, vol. 1, no. 2, pp. 69-9.7, 2 pls., January, 1918.

975. Paleontology and stratigraphy of the Porter division of the Oligocene in Washington (abstract): Geol. Soc. America, Bull, vol, 29, no. 1, p. 166, March 31, 1918.

Vaughan, F. E.

976. Evidence in San Gorgonio Pass, Riverside County, of a late Pliocene extension of the Gulf of Lower California (abstract): Geol. Sac. America, Bull., vol. 29, no. 1, pp. 164-165, March 31, 1918.

Vaughan, Thomas Wayland.

977. Chemical and organic deposits of the sea: Geol. Soc. America, Bull., vol. 28, no. 4, pp. 933-944, 2 pls., December 19, 1917.

978. Study of the stratigraphic geology and of the fossil corals and associated organisms in several of the small West Indian Islands: Carnegie Inst. Washington, Year Book no. 16, 1917, p. 319, 1918.

979. Correlation of the Tertiary geologic formations of the southeastern United States, Central America, and the West Indies: Washington Acad. Sci., Jour., vol. 8, no. 9, pp. 268-276, May 4, 1918.

980. Geologic surveys and the eradication of malaria: Southern Medical Jour., vol, 11, no. 8, pp. 569-572, August, 1918.

Geology of Cuba; a reprint of the chapters on physiography and general geology from the "Report on a geological reconnaissance of Cuba," partly revised by Pablo Ortega. See Hayes and others, no. 421. 
Vaughan, Thomas Wayland, and others.

981. Some shoal-water bottom samples from Murray Island, Australia, and comparisons of them with samples from Florida and.the Bahamas: Carnegie Inst. Washington, Papers from the Department of $\mathrm{Ma}_{\text {- }}$ rine Biology, vol. 9 (Pub. no. 213), pp. 235-288, 2 pls , figs., 19its.

\section{Villafaña, Andres.}

982. Reseña minera de la regiôn central y sureste del estado de Jalisco. 175 pp., pls., México, Departamento de talleres gráficos de la Secretario de Fomento, 1916.

\section{Von Engeln, O. D.}

983. Transportation of débris by icebergs: Jour. Geology, vol. 26, no. 1, pp. 74-\$1, 5 figs., January-February, 1918.

984. Glacial erosion of rock basins; with especial reference to the conditions applying in the Finger Lake region, of central New York (abtract) : Assoc. Am. Geographers, Annals, vol. 7, pp. 83-85 [1918].

Von Herrmann, C. F.

985. The desiccation of the earth: Science, new ser., vol. 47, p. 417, April 26, 1918.

Wade, Bruce.

986. New generic names for upper Cretaceous Gastropoda: Am. Jour. Sci., 4th ser., vol. 45, p. 334, April, 1918.

Waite, V. V.

The geology of Runnels County. See Beede and Waite, no. 59.

Walcott, Charles D.

987. Is "Atikoliania lawsoni" a concretion? Nature, vol. 94, p. 478, December $31,1914$.

988. Cambrian geology and paleontology, IV; No. 4, Appendages of trilobites: Smithsonian Misc. Coll., vol. 67, no. 4, pp. 115-216, 29 pls., 3 figs., December, 1918.

Walker, T, L.

Cerusite from Salmo, British Columbia. See Ledoux and Walker, nọ. 550.

Wallace, R. C.

989. The origin of the gold deposits in the Canadian pre-Cambrian: Canadian Min. Inst., Monthly Bull., no. T4, "pp. 538-540, June, 1918.

Wallace, R. C., and De Iury, J. S.

990. The mineral belt north of The Pas [Manitoba] : in Northern Manitoba, pp. 19-22, issued by the Province of Manitoba, November, 1917.

Waring, Clarence A.

991. Geological map of Inyo County, California: California State Min. Bur, 191\%. Scale 1:25,000.

See also Bradley and otheris, no. 100.

Waring, Gerald $A$.

992. Mineral splings of Alaska (U. S. Geol. Survey, Water-Supply Paper 418, 1917) : Abstract, Washington Acad. Sci., Jour., vol. 8, no. 6, p. 171 , March 19,1918 .

993. Ground water in Reese River basin and adjacent parts of Humboldt River basin, Nevada: U. S. Geol. Survey, Water-Supply Paper 425 , pp. 95-129, 6 pls. (incl. map), 1 fig., December 26, 1918. 
Warren, Charles $\mathrm{H}$.

994. On the microstructure of certain titanic iron ores: Econ. Geology, vol. iso. . . 413 , no. 6, pp. 419-446, 6 pls., September, 1918.

washburnercedirleton W., and Washburne, Heluiz Chandler.

955. The stoily of the earth. 107 pp., 11 pls., 30 figs., New York, The Century Co., 1916.

Washburne, Chester W.

996. ['The movenients of oil and gas through rocks] (discussion): Econ. Geology, vol. 13, no. 7, pp. 55u-551, November, 1918.

See also Matteson, no. 634 .

\section{Washington, Henry S.}

997. Chemical analyses of igneous rocks published from 1884 to 1.913, inclusive (U. S. Geol. Survey, Prof. Paper 99, 1917) : Abstract, Washington Acad. Sci., Jour., vol. 8, no. 3, p. 66, February 4, 1918.

998. A description of the quantitative classification of igneous rocks, with tables for the calculation of the norm: U. S. Geol. Survey, Extract from Prof. Paper 99 (appendixes 1-5), pp. 1-7, 1151-1180, 191.8.

999. Persistence of vents at. Stromboli and its bearing on volcanic mechanism (Geol. Soc. America, Bull., vol. 28, pp. 249-278, 1917): Abstract, Washington Acad. Sci., Jour., vol. 8, no. 7, p. 207, April 4, 1918.

Washington Geological Survey.

1000. The biennial report of the Board of Geological Survey of the State of Washington for the term 1915-1917. 25 pp., Olympia, Wash., 1917.

Watkins, Joel H.

1001. Pyrite mining at Kershaw, South Carolina: Eng. and Min. Jour., vol. 106, pp. 517-521, 6 tigs., September 21, 1918.

Watson; D. M. S. See Gregory, no. 369.

Watson, Thomas L.

1002. The relation of sphalerite to other sulphides in ores (discussion): Am. Inst. Min. Eng., Bull. no. 136, pp. 843-845, April, 1918.

1003. Manganese, its occurrence and commercial uses: Mineral Föote-Notes, vol. 2 , no. 6, pp. 3-12, June, 1918.

1004. The color change in vivianite and its effect on the optical properties: Am. Mineralogist, vol. 3, no. 8, pp. 159-161, August,.1918.

1005. Pyrolusite from Virginia: Washington Acad. Sci., Jour., vol. 8, no. 16, pp. 550-560, 1 fig., October $4,1918$.

1006. The Virginia earthquake of April 9, 1918: Seismol. Soc. America, Bull., vol. 8, no. 4, pp. 105-116, map, December, 1918.

See also Teas, ho. 936 .

Watson, Thomas L., and Gooch, Stapleton D.

1007. Vivianite from the land pebble phosphate deposits of Florida: Washington Acad. Sci., Jour., vol. 8, no. 4, pp. S2-88, February 19, 1918.

Watson, Thomas L., and Steiger, George.

1008. Titanium-bearing corundum spinellite (rock emery); a preliminary statement of its occurrence and composition in Virginia: Washington Acad. Sci., Jour. vol. 8, no. 21, pp. 665-676, December 19, 1918.

Weaver, Charles E.

1009. Paleogreography of the Oligocene of Washington (abstract) : Geol. Soc. America,"Bull., vol.'29, no. 1, pp. 165-166, March 31, 1918. 
Wegemann, Carroll H.

1010. The Salt Creek oil field, Wyoming: U. S. Geol. Surrey, Eull: 670, 52 pp., 7 pls. (incl maps), 2 figs., 1918. Alsstract, by K. W. Stone, Washington Acad. Sci., Jour., vol. 8, no. 1æi, p. 53s, September 19,1918 .

19lequl $\quad 3: 1$

Weld, C. M.

1011. Notes on certain iron-ore resources of the world; Cuba: Am. Inst. Min. Eng., Bull. 1o. 141, pp. 1479-1485, September, $191 \mathrm{~s}$.

Weller, Stuart.

1012. Henry Shaler Williams, 1847-1918: Jour. Gerology, wl. '26, no.' 8 , pp. 698-700, November-December, 1918 .

Wells, Roger C.

1013. The solubility of calcite in sea-water in contact with the atmosphere, and its variation with temperature: Carnegie Inst. Washington, Papers from the Department of Marine Biology, vol. 9 (Pub. no. 213), pp. 316-318, 1918.

1014. Tungstenite, disulphide of tungsten, a new mineral (abstract) : Washington Acad. Sci., Jour., vol. \&, no. 4, p. 99, February 19, 1918.

1015. New determinations of carbon dioxide in water of the Gulf of Mexico: U. S. Geol. Survey, Prof. Paier 120, pi. 1-6, 1 fig., June 20, 1918. Abstract, by R. W. Stone, Washington Acad. Sci., Jour., vol. S, no. 15 , pp. 539-540, September. 19, 1918:

Weston, W.

1016. Report on the Iampa coal field of Colorado. 62 pp., pls. and matss, Denver \& Salt Lake Railroad, 1914.

Wheeler, Arthur 0.

1017. Notion of the Yoho Glacier, 1916-1917: Canadian Alpine Jour., vol. 9, pp. 76-7S, 1 pl., $191 \mathrm{~S}$.

Wheeler, H. A.

1018. Oil and gas fields of Illinois: Eng. and Min. Jour., vol, 105, pp. 181184,3 figs., January 26, 1918.

1019. Uncertainties of geological evidence: Eag. and Min. Jour., vol. 106, pp. S7S-879, November 16, 1918.

See also Tarr, no. 929.

Wherry, Edgar T.

1020. Notes on mimetite, thaumasite, and wavelite: U. S. Nat. Mus., Froc., vol. 54, pp. 373-381, 1 pl., 1918.

1021. Famous mineral localities; 1 , The Leokuk geode region: Am. Mineralogist, vol. 3, no. 1, pp. 3-5, January, 1918.

1022. The life and work of Amos Peaslee Brown: Am. Mineralogist, vol. 3, no. 3, pp. 21-23, March, 1918 .

1C23. Famous mineral localities; 5 , The Black Hills of South Dakota :'Am. Mineralogist, vol. 3 no. 5, pp. 44-46, May, 1918.

1024. Some minerals from Sylmar, Pennsylvania: Am. Mineralogist ,rol. 3, no. 5 , p. 47, May, 1918 .

1C25. Field identification of diasporite: Am. Mineralogist, vol. 3, no. 7 , p. 154, July, 1918.

1025. The assignment of crystals to symmetry classes: Washington Acad. Sci., Jour., vol. 8, no. 14, pp. 480-487, August 19, 1918.

1027. Note on iron as a caise of blue colors in minerals: Am. Mineralogist, vol. 3 , no. 8 , D. 161, August, 1918 . 
Wherry, Elgar T.-Continued.

1028. Pre-Cambrian sedimentary rocks in the Fighlands of eastem Pennsyl-

. i Mania: Geol. Soc. America, Bull., vol. 29, no. 3, p. 375-392, 1.t : j̧̣s., September 30, 1.91s.

1029. Supplementary note on meteoritic iron phosphide: Am. Mineralogist, rol. 3 , no. 10 , p. 1S4, October, 1918.

Famous mineral localities; 4, The Joplin district. See Hawkins and Wherry, no. 414.

Whitaker, W. A., Estes, Clarence, and Campbell, F. W.

1030. The petroleum industry in Kansas: Eng. and Min. Jour., vol, 105, pp. 817-821, 4 figs., May 4, 1918.

White, David.

1C31. Structure and oil and gas resources of the Osage Reservation, Oklahonia ; Introduction: U. S. Geol. Survey, Bull. 686, pp. v-xii, 1 pl. (map), 1918.

White, Israel C.

1032. Petroleum and natural gas in West Virginia: Natural Gas Assoc. America, 6th Ann. Meeting, pp. 82-103, 1911.

1033. The deepest well in the world and the next deepest in America : Natural Gas Assoc. America, Proc., 13th Ann. Meeting, Pittsburgh, 1918, pp. S0-99, 4 figs., 1918.

103it. Some definite correlations of West Virginia coal beds in Mingo County, West Virginia, with those of Letcher County, southeastern Kentucky (abstract) : Geol. Soc. America, Bull., vol. 29, no. 1., 1. 96, March 31, 1918.

1035. Records of three very deep wells drilled in the Appalachian oil fields of Pennsylvania and West Virginia (abstract, with discussion by Mr. Decker and F. R. Van Horn ) : Geol. Soc. America, Bull;, vol. 29, no. 1, pp. 96-97, March 31, 1918.

1036. Discussion of the records of some very deep wells in the Appalachian oil fields of Pennsylvania, Ohio, and West Virginia; West Virginia Geol. Surrey, Barbour and Upshur counties, pp. xxr-lxr, 5 pls. (incl. maps), 1918.

White, I. C., and others.

1037. Map of West Virginia showing coal, oil, gas, iron ore, and limestore areas. Scale 8 miles to 1 inch. West Virginia Geol. survey, 1917.

Whiteside, F. T.

1038. Coal measures of the Front Range of: the Rocky Mountains in Colorado: Colorado, Univ., Jour. Engineering; no. 8, pl. 50-55, May, 1912.

Whitson, A. R., and others.

1039. Reconnaissance soil survey of northeastern Wisconsin: Wisconsin Geol. and Nat. Hist. Survey, Bull. no. 47, $87 . p p ., 10$ pls., 3 figs., map, 1916.

1040. Soil survey of Jefferson County, Wisconsin: Wisconsin, Geol, and Nat. Hist. Survey, Bull. no. 48, 77 pp., 3 pls., 3 figs., map, 1916.

1041. Soil survey of Columbia County, Wisconsin: Wisconsin Geol. and Nat. Hist. Survey, Bull. no. 49, 84 pp., 4 pls., 3 figs., map, 1916.

1042. Reconnaissance soil survey of north part of north central Wisconsin: Wisconsin Geol. and Nat. Hist. Survey, Bull. no. 50, 78 pp.. 10 pls., 3 figs., map, 1916. 
Whittaker, E. J.

1043. The relationship of the fossil marl fauna of Mackay Lake, Ottawa, to the present molluscan fauna of the lake: Ottawa Naturalist, vol. 32, no. 1, pp. 14-18, April, 1918.

Wieland, G. R.

10\$4. Cycadeoid wood structure: Science, new ser., vol. 47, pp. 141-142, February 8, 1918.

1045. The origin of dicotyls: Science, new ser., vol. 48, pp. 18-21, July 5, 1918.

1046. The Vero man and the sabre tooth [tiger]: Science, new ser., vol: 48 , pp. 93-94, July 26, 1918.

1047. A study of some American fossil cycads, Part VIII; Notes on young floral structures: Am. Jour. Sci., 4th ser., vol. 46, pp. 645-650, 1 fig., November, 1918.

Williams, Ira A.

1048. Nitrate deposits of southeastern Oregon: Min. and Sci. Press., rol. 117, pp. 285-289, 1 tig., August 31, 1918.

Williams, J. C.

1049. Chromite: Colorado School of Mines Miag., vol. S, no. 9, pp. 15i-159, September, 1918.

Williams, M. $\mathbf{Y}$.

1050. The late Dr. C. W. Drysdale: Canadian Min. Inst., Monthly Bull., no. 69 , pp. 66-69, port., January, 1918.

1051. The geologist and the development of our oil fields: Canadian Min. Inst., Monthly Bull., no. 74, pp. 52S-538, 2 figs., June, 1918.

1052. Oil prospecting in southwestern Ontario: Canadian Min. Jour., vol. 39, no. 4, pp. 48-49, 2 figs., February 15, 1918.

Williàms, Stephen $\mathbf{R}$.

1053. Concerning the structure of Agelacrinites and Streptaster Edrioasteroidea of the Richmond and Maysville divisions of the Ordovician : Ohio Jour. Sci., vol. 19, no. 1, pp. 59-\$6, 9 pls., November, 1918.

Willig, H. L.

1054. Limonite pseudomorphous after pyrite from Lancaster Co., Pa.: Am. Mineralogist, vol. 3, no. 1, p. 2, January, 1918.

Williston, Samuel Wendell.

1055. The evolution of rertebrae: [Chicago, University], Walker Museum, Contr., vol. 2, no. 4, pp. 75-\$5, 6 figs., March, 1918. Abstract, Geol. Soc. America, Bull., vol. 29, no. 1, p. 146, March 31, 1918.

1056. The osteology of some American Permian vertebrates, III : [Chicago, University], Walker Museum, Contr., vol. 2, no. 4, pp. 87-112, 2 pls., 13 figs., March, 1918.

See also Gregory, no. 369.

Wilson, Malcolm E.

1057. Oil and gas possibilities in the Belton area: Missouri Bur. Geology and Mines, 39 pp., 3 pls. (incl. maps), 1918.

See also Grout, no. 379 .

Wilson, Morley E.

1058. Timiskaming County, Quebec: Canada, Geol. Survey, Mem. 103, 197 pp., 16 pls. (incl. map), 6 figs., 1918.

1059. Molybdenite deposits of Quyon district, Quebec: Canadian Min. Jour., vol. 39, no. 5, pp. 78-80, 3 figs., March 1, 1918. 
Wilson, Morley E.-Continued.

1060. The subprovincial limitations of pre-Cambrian nomenclature in the st. Tawreuce basin: Jour. Geology, vol. 26, no. 4, pp. 325-333, MayJune, 1918. Abstract, with discussion by A. F. Coleman and W. J. Miller: Geol. Soc. America, Bull., vol. 29, no. 1, pp. 90-92, March 31, $191 \mathrm{~s}$.

Winchell, Alexander Newton.

1061. Racewinite, a peculiar mineral from ore deposits in Utah: Econ. Geology, vol. 13, no. 8, pp. 611-615, December, 1918.

Winchell, Alexander Newton, and Miller, Eric Rexford.

1062. The dust-fall of March 9, 1918: Am. Jour. Sci., 4th ser., vol, 46, pp. 599-609, 3 tigs., October, 1918.

1063. The dustfalls of March, 1918: Monthly Weather Review, vol. 46, pp. 502-506, November, 1918.

Winchester, Dean E.

1064. Oil shale in the United States: The Railroad Red Book (Denver \& Rio Grande Railroad), vol. 35, no. 1, pp. 33-38, 3 figs., Jalluary, 1918.

1065. Oil shale of the Uinta Basin, northeastern Utah: U. S. Geol. Survey, Bull. 691, pp. 27-50, 8 pls. (incl. map), 1 fig., April 30, 1918. Abstract, by R. W. Stone, Washington Acad. Sci., Jour., vol. 8, no. 14, p. 501, August 19, 1918.

Includes sections of Green River formation in northwestern Colorado.

1066. Results of dry distillation of miscellaneous shale samples: U: S. Geol. Survey, Bull. 691, pp. 51-55, April 30, 1918.

1066a. Structure and oil and gas resources of the Osage Reservation, Oklahoma; T. 27 N., R. 9 E. : U. S. Geol. Survey, Bull. 686, pp. 11-1.5, 1. pl. (map), 2 figs., 1918.

Winchester, Dean E., Heald, K. C., and others.

1067. Structure and oil and gas resources of the Osage Reservation, Oklahonı ; T. 25 N., R. 10 E. : U. S. Geol. Survey, Bull. 686, pp. 59-73, 1 pl. (map), 6 figs., 1918.

\section{Wisconsin Geological and Natural History Survey.}

1068. Eleventh biennial report of the commissioners of the [Wisconsin] Geological and Natural History Survey, covering the period from July 1, 1916, to June 30, 1918. 40 pp., 1 pl., Madison, Wis., 1918.

\section{Wittich, Ernesto.}

1069. Contribuciones ‘ la mineralogra mexicana: Soc. cient. "Antonio Alzate," Mem., t. 37, no. 1, pp. 23-42, 1 fig., May, 1918.

1070. Fenómenos desérticos en los alrededores de San Luis Potosí : Soc. cient. "Antonio Alzate," Mem., t. 37, no. 2, pp. 65-70, 3 pls., June, 1918.

Wolcott, H. N.

1071. The replacement of sulphides by quartz: Am. Inst. Min. Eng., Trans., vol. 58, pp. $385-388,4$ figs., 1918.

Wolf, Harry J.

1072. Molybdenum: Colorado School of Mines Mag., vol. 8, no. 5, pp. 71-74, May, 1918.

1073. Mining in the Telluride district of Colorado: Eng. and Min. Jour., vol. 106, pp. 395-399, 3 figs, August 31, 1918.

$122541^{\circ}-19-6$ 
Wolff, J. F.

1074. Recent geologic development on the Mesabi iron range, Minnesota (discussion) : Am. Inst. Min. Eng., Bull. no. 141, pp. 1523-1524, September, 1918.

Wood, Harry O.

1075. The study of earthquakes in southern California: Seismol. Soc. America, Bull., vol. 8, no. 1, pp. 28-33, March, 1918.

Woodruff, E. G. See also Bucher, no. 116.

Woodruff, Lorande Loss.

1076. The origin of life. In The evolution of the earth and its inhabitants [edited by R. S. Lull], pp. 82-108, New Haven, Yale University Press, 1918.

Wooster, Lyman C.

1077. Glacial moraines in the vicinity of Estes Park, Colorado: School Science and Mathematics, vol. 18, pp. 263-267, March, 1918.

Wright, Clarence A:

1078. Mining and milling of lead and zinc ores in the Missouri-Kansas-Oklahoma zinc district: U. S. Bur. Mines, Bull. 154, 134 pp., 17 pls., 13 figs., 1918.

Wright, G. Frederick.

1079. Evidence from Alaska of the unity of the Pleistocene glacial period: Science, new ser., vol. 47, p. 364, April 12, 1918.

1080. Explanation of the abandoned beaches about the south end of Lake Michigan: Geol. Soc. America, Bull.., vol. 29, no. 2, pp. 235-244, 3 figs., June 30, 1918.

Wright, Park.

1081. Granite in Kansas wells: Am. Inst. Min. Eng., Tragis., vol. 57, pp. 906-913, 1 fig., 1918.

Wyer, Samuel S.

6.ㄷ․

1082. Natural gas; its production, service, and conservation: U. S. Nat. Mus., Bull. 102, pt. 7, 66 pp., 8 pls., 20 figs., 1918.

Yale, Charles G., and Gale, Hoyt S.

1083. Borax in 1916: U. S. Geol. Survey, Mineral Resources, 1916, pt. 2, pp. 387-389, 1 pl. (map), January 7, 1918.

1084. Magnesite in 1916: U. S. Geol. Survey, Mineral Resources, 1916, pt. 2 , pp. 391-401, January 16, 1918.

Yale, Charles G., and Stone, Ralph W.

1085. Magnesite in 1917: U. S. Geol. Surrey, Mineral Resources, 1917, pt. 2, pp. 63-79, July 19, 1918.

Young, Geo. J.

1086. The sink of the Amargosa [Death Valley, Inyo County, California]: Eng. and Min. Jour., vol. 105, pp. 985-986, June 1, 1918.

Young, Jacob W.

1087. The halogen salts of silver at Wonder, Nevada (discussion): Econ. Geology, vol. 13, no. 3, pp. 224-225, May, 1918.

Ziegler, Victor.

1088. Fopular oil geology. 149 pp., 62 figs., Golden, Colorado, C. H. Merrifield, 1918. 
Ziegler, Victor-Continued.

1089. Oil shales and their utilization: The Railroad Red Book of the Denver \& Rio Grande Railroad, vol. 35, no. 3, pp. 13-20,7 figs., March, 1918.

1090. The movements of oil and gas through rocks: Econ. Geology, vol. 13, no. 5, pp. 335-348, July, 1918.

1091. Colorado's future as an oil producer: Colorado School of Mines, Quart., vol. 13, no. 4, pp. 3-19, 4 figs., October, 1918.

Anonymous.

1092. Some tungsten ores in the National Museum: Science, new ser., vol. 47, pp. 412-413, April 26, 1918.

1093. Explorations and field work of the Smithsonian Institution in 1917: Smithsonian Misc. Coll., vol. 68, no. 12, 133 pp., 137 figs., June, 1918.

1094. The Guatemala enrthquake of December, 1917, and January, 1918: Geog. Rev., vol. 5, no. 6, pp. 459-469, 6 figs., June, 1918.

1095. The country around Camp Grant [Illinois]. [Text on back of topographic map], Illinois, Camp Grant quadrangle, U. S. Geol. Survey, 1918.

1096. Manganese ore in Georgia: Science, new ser., vol. 48, pp. 360-362, October 11, 1918.

1097. Manganiferous ore in Oregon: Science, new ser., vol. 48, pp. $439-440$, November 1, 1918.

'1098. Chàrlès Richard Van Hise: Eng. and Min. Jour., vol. 106, pp. 9991000, port., December 7, 1918.

$\therefore$ 1099. A century of science in America, with special reference to the American Journal of Science, 1818-1918, by Edward Salisbury Dana, Charles Schuchert, Herbert E. Gregory, Joseph Barrell, George Otis Smith, Richard Swann Lull, Louis V. Pirsson, William E. . e.Pord, R. B. Sosman, Horace L. Wells;.Harry W. Foote, Leigh Page, Wesley R. Goe, and George L. Goodale. 458 pp., New Haven, Yale University Press, 1918.

Reproduced with some additions from the Centennial Number, 1818 1918 (July, 1918), of the American Journal of Science. 'The contributions that relate to geology have been entered under the individual authors. 



\section{OUTLINE OF SUBJECT HEADINGS.}

In the following index the subject headings are printed in black-faced type. Ail outline of these is here given that it may be quickly seen which subject heacling. of two or more synonyms has been adopted. Thus "petroleum" and not "oil" nor "rock oil" has been chosen. That the specialist may see at a glance under what headings to find cognate literature, subject headings that are more or less closely related have been grouped together under the following heads: Areal or regional, general, economic, dynamic and structural, physiogriphic, stratigraphic or historical, paleontology, petrology, mineralogy, underground water. In the index the specific entries under the areal or regional subject headings are alphabeted under these same heads arranged in the same order, namely, general, economic, etc.

\section{AREAL OR REGIONAL.}

The States and Territories of the Union, Alabama, Alaska, etc.; The Provinces of Canada, Alberta, etc.; Greenland; Arctic regions; Mexico; the countries of Central America; the West Indies, and the single islands; the Hawaiian Islands.

GENERAL.

Associations, meetings ; Addresses ; Philosophy ; History ; Biography ; Bibliography; Education; Textbooks.

Surveys; Fieldwork ; Excursions ; Technique; Cartography.

Classification; Nomenclature.

Geochemistry; Chemical analyses (list); Geophysics; Atmosphere; Radioactivity.

Experimental investigations; Borings; Miscellaneous.

\section{ECONOMIC.}

Ore deposits, origin; Contact phenomena.

Gold; Placers; Black sands; Silver; Quicksilver; Nickel ; Cobalt; Copper ; Lead; Zilic; Iron; Magnetite; Manganese; Tiu.

Aluminum; Bauxite; Antimony; Bismuth; Tungsten; Vanadium; Uranium ; Carnotite ores; Molybdenum; Chromic iron ore.

Platinum ; Palladium ; Titanium ; Rutile; Rare earths ; Monazite ; Zircon:

Coal; Anthracite; Ijignite; Peat.

Petroleum; Natural gas; Oil shales; Asphalt; Albertite; Gilsonite; Bituminous rock.

Stone; Building stone; Granite; Trap ; Bluestone ; Limestone ; Marble ; Lime ; Gypsum.

Sand; Glass sand; Silica ; Qurtrtz; Quartzite; Sandstone ; Gravel ; Cement anj cement materials; Concrete materials ; Road materials.

Clay ; Kaolin; Bentonite; Fire Clay; Ganister ; Slate; Shale ; Pyrophyllite.

Serpentine; Asbestos; Steatite; Soapstone; Talc.

I'recious stones; Diamonds; Sapphires; Turquoise; Tourmaline; Onyx.

Abrasive materials; Corundum; Emery; Garnet; Diatomaceous earth; Tripoli; Volcanic ash; Pumice; Millstones; Whetstones; Novaculite; Feldspar. 
Phosphate; Apatite; Potash; Alunite; Nitrate; Glauconite; Marl.

Salt; Salines; Bromine; Calcium chloride; Borax; Fluorspar.

Barite; Strontium; Mineral paints.

Arsenic; Fuller's earth ; Infusorial earth ; Magnesite; Mica ; Graphite.

Phosphorus; Sulphur; Pyrite.

Soils.

DYNAMIC AND STRUCTURAL.

Earth, genesis of; Earth, age of ; Earth, interior of ; Earth, temperature of. Volcanism; Volcanoes; Earthquakes; Seismology; Seismographs; Mud rolcanoes.

Isostasy ; Orogeny; Changes of lerel.

Magmas; Magmatic differentiation; Laçcoliths; Intrusions; Dikes; Contact phenomena.

Deformation ; Folding; Faulting; Unconformities.

Conglomerates; Concretions; Stalactites; Jointing; Cleavage.

Denudation; Erosion; Coast changes; Coral islands and reefs; Weathering; Caves; Sink holes; Wind work; Dunes; Loess; Landslides.

Glaciers; Glacial erosion; Glacial striæ; Potholes ; Kettle holes.

Sedimentation ; Esker's ; Kames ; Moraines.

Drainage changes.

PHYSIOGRAPHYC.

Geomorphy; Relief maps.

Plains; Prairies; Peneplains; Valleys; Cirques; Deserts; Alluvial fans; Deltas; Mounds, natural; Sink holes; Karsts; Natural bridges.

Rivers; Stream piracy; Meanders; Falls; Lakes; Swamps; Marshes; Everglades.

Terraces; Beaches; Shore lines.

\section{STRATIGRAPHIC OR HISTORICAL.}

Geologic history; Geologic time; Paleogeography; Paleogeographic maps; Paleoclimatology.

Geologic maps; Geologic formations described (list); Tables of formations; Unconformities; Borings.

Pre-Cambrian; Paleozoic (undifferentiated); Cambrian; Ordovician; Silurian; Devonian; Carboniferous; Mesozoic (undifferentiated) ; Triassic; Jurassic; Cretaceous; Tertiary; Quaternary; Recent.

Glacial geology; Glaciation; Drift deposits ; Glacial lakes; Erratic boulders; Ice ages (ancient).

\section{PALEONTOLOGY.}

Geographic distribution; Evolution; Restorations.

Vertebrata; Man, fossil; Mammalia; Aves; Reptilia; Amphibia; Pisces; Footprints.

Invertebrata ; Arthropoda ; Crustacea ; Trilobita ; Ostracoda ; Insecta ; Arachnida; Myriapoda.

Mollusca; Cephalopoda ; Gastropoda; Pelecypoda.

Molluscoidea ; Brachiopoda; Bryozoa; Vermes.

Echinodermata ; Echinoidea; Asteroidea ; Crinoidea ; Cystoidea:

Coelenterata; Anthozoa; Hydrozoa; Graptolites.

Protozoa; Spongida; Foraminifera.

Paleobotany ; Diatoms; Algæ.

Problematica. 
PETROLOGY.

Rocks, origin; Rocks, structural features; Rocks described (list); Igneous and volcanic rocks; Rock-forming minerals; Lava; Oolite; Dolomite; Pebbles.

MINERALOGY.

Minerals described (list); Crystallography; Pseudomorphism; Paragenesis of minerals; Rock-forming minerals; Meteorites.

\section{UNDERGROUND WATER.}

Mineral waters; Thermal waters; Geysers; Springs; Mine waters.

$r$

Y

P.

1*

(3) 
(5) $\mathrm{ji}^{\text {" }}$

0

ज斻.

wh.19

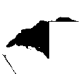

$+$
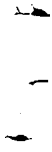

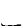
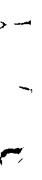


\section{INDEX.}

(The numbers refer to entries in the bibliography.)

Abrasives.

General : Katz, 496.

\section{Addresses.}

Experiment in geology: Adams, 3.

Geology and the public service: Smith, 873.

Geology in education: Salisbury, 812. laleontology of arrested evolution: Ruedemann, 808 .

Philosophy of geology and the order of the state: Clarke, 182.

Adirondack anorthosite: Miller, 677.

Age flow and ebb of the Eocene seas: IIarlis, 406.

\section{Alabama.}

Economic.

Iron, hematite, Birmingham district: Singewald, 868 .

Oil and gas possibilities: Hager, 387 .

Physiographic.

Camp McClellan, Anniston quadrangle : Matthes, 687.

stratigraphic.

General : Hager, $3 \$ 7$.

Correlation of Jackson and Vicksburg deposits: Cooke, 205.

Chester series: Ulrich, 962.

Tertiary, correlation: Vaughan, 979.

Mineralogy.

Tourmaline, Micaville, Randolph County: Van Horn, 967.

\section{Alaska.}

General.

Sedimentary record of climate: Blackwelder, 77 .

Yukon River region, late Tertiary and Quaternary bistory: Harrington, 405 .

\section{Economic}

Chitina Valley: Moffit, 683.

Gold, silver, copper, and lead in 1917 : Martin, 623.

Gold, Nelchina-Susitna region : Chapin, 168.

Lake Clark-central Kuskokwim region: Smith, 878 .

Nelchina-Susitna region: Chapin, 168. 'Jungsten near Fairbanks: Bateman, 52.

Dynamic and structural.

Katmai: Griggs, 372.

eruption: Girlggs, 373.

Ten Thousand Smokes: Griggs, 374. hot mud flow: Griggs, 375.

Volcanoes : Dall, 220.

\section{Alaska-Continued.}

Physiographic.

Cosna-Nowitna reglon, Alaska : Eakin, 275.

Glaciation: Muir, 701.

Lake Clark-central Kuskokwim region: Smith, 878.

Nelchina-Susitna reglon: Chapin, 168.

Valdez delta: Johnson, 479.

Stratigraphic.

Chiiina Valley: Moffit, 683.

Cosna-Nowitna region, Alaska : Eakin, 175.

Gravina Island: Chapin, 167.

Lake Clark-central Kuskokwim region : Smith, 878.

Nelchina-Susitna region: Chapin, $\mathbf{1 . 6 8}$.

Ordovician, southeastel'n Alaska: Kirk, 520.

Paleozoic g $\mathbf{l}$ a $\mathrm{c}$ i a $\mathbf{t}$ i o $\mathbf{n}$, southeastern Alaska: Kirk, 521.

Revillagigedo Island: Chapin, 167.

Paleontology.

Isocrinus, Triassic: Bather, 56.

Petrology.

Igneous rocks, Chitina Valley: Overbeck, 727 .

Mineralogy.

Chalmersite: Johnson, 478.

\section{Alberta.}

Economic.

Natural gas: Dowling, 265.

Viking field: Slipper, 871.

Petroleum, Peace River region: McLearn, 610.

Sheep River area: Slipper, 870.

Stratigraphic.

Borings, Southern Alberta: Dowling, 262.

Central Alberta: Allan, 12.

Peace River section: McLearn, 610.

Viking area : Slipper, 871.

Whitemans Pass section: Drysdale and Burling, 268.

\section{Paleontology.}

Monoclonius, Red Deer River: Brown, 1.07.

Selachian, Cretaceous: Lambe, 544.

Stegosaurus: Lambe, $\mathbf{5 4 5 .}$

Vertebrate fossils: Sternberg, 911.

Underground water.

Southern Alberta : Dowling, 262.

\section{Algae.}

Lithothamninas, Panama Canal Zone: Howe, 462 . 
Algal limestone, Belcher Islands: Moore, 693.

Algonkian. Sce Pre-Cambrian.

Alkaline rocks, genesis: Daly, 225.

Aluminum.

General: Hill, 434.

Alunite.

Nevada, Humboldt County, Sulphur: Clark, 176.

Ammonites. See Cephalopoda.

Amphibia.

Diplocaulus, structure and relationships: Douthitt, 261.

Permian : Williston, 1056.

Amsden formation, Wyoming: Branson and Greger, 103.

Anne Arundel County, Maryland: Little, 577.

Anomaious dips: Shaw, 857.

Antimony.

General: Bastin, 49.

California: Boalich and Castello, 84 .

Idaho, central: Bell, 62.

Nevada, Arabia district: Knopf, 529.

Appalachian peneplains, age: Shaw, $\$ 56$.

Arctic region:.

Physiographic.

Ellesmere and Grinnell lands: Holtedahl, 447.

Glaciation : Muir, 701.

Stratigraplicic.

Ellesmere and Grinneli lands: Holtedahl, 447.

Paieontology:

Ellesmere and Grinnell lands: Holte-

Mineralogy. dahI, 447 .

Tourmaline, Macdonald Island, Baffin Land: Ledoux, 549.

\section{Arizona.}

Economic.

Copper: Finlay, 312.

Ajo, Pima County: De Kaib, 247.

Bisbee, Sacramento Hill deposit: De Kalb, 248.

Jerome district : Finlay, 313 ; Provot, 769 ; Rickard, 789.

Cunningham Pass district: Tovote, 951.

Jerome district: Finlay, 313; Provot, 769.

Manganese: Allen and Butler, 15.

Ore deposits of the Sonthwest: Tovote, 952 .

Quicksilver, Phoenix Mountains: Schr'adel', 826.

Dynamic and structural.

Rhythmic banding of manganese diox-

\section{Stratigraphic.} ide in rhyolite tuff: Tarr, 934.

Cambrian, Grand Canyon: Schuchert, 829.

Carboniferous, Grand Canyon: Schnchert, 828.

Jerome district: Provot, 769 ; Rickard, 789 .
Arizona-Continued.

Paleontology.

Footprints, Grand Canyon: Lull, 600. Petrology.

Jerome ores: Rice, 783 .

Arkansas.

Economic.

Asphalt, southwestern .Arkansas : Miser and Purdue, 679.

Gravel, Caddo Gap and De Queen quadrangles : Miser and Purdue, 680.

Physiographic.

Camp Pike, Little Rock quadrangle: Stephenson and Miser, 910.

Northeastern Arkansas: Shaw, 851.

Stratigraphic.

Caddo Gap and De Queen quadrangles:

Arsenic. Miser and Purdue, 680 .

General : Umpleby, 964, 965.

Artesian waters and wells. See Cnderground water.

Asbestos.

General : Diller, 256, 259.

Asphalt. See also Grahamite.

General: Northrop, 713 :

Arkansas, southwestern: Miser and Pardue, 679.

Associations, meetings.

American Association, Pittsburgh meeting: Salisbury, 811

Geological Society, of Americn, St. Louis meeting, 1917: Hovey, 460. . is. E

Paleontological Society; Pacific coast section, eighth : meeting: Stock, 915.

Aves.

Pittsburgh meeting, 1917-18 : Bassler, 46.

Diatryma, Bighorn Basin, Wyoming: Matthew and Granger, 648 .

Florida: Shufelt, 863 .

Balanidae, phylogeny: Ruedemann, $\mathbf{8 0 9}$.

Barbados.

Economic.

Oil prospecting: Craig, 210.

Stratigraphic.

General : Craig, 210.

Barite.

General : Hill, 438.

Missouri : Tarr, 932.

Tennessee, Sweetwater district: Gordon, 343.

Barytes. See Barite.

Bathyliths. See Intrusions.

Batrachia. See Amphibia.

Bauxite.

General : Hill, 434.

Beaches, See also Shore lines; prettaces

Lake Michigan, south end: Wright, 1080.

Ontario, Ottawa valley: Kindle, 517. 
Bibliography.

Brown, A. P., writings: Penrose, 749).

Cairnes, D. D., writings: Camsell, 151. California, State Mining Bureau publications: Boalich, 28.

Clark, W. B., writings : Clarke, 186.

Colorado, Raton Mesa region: Lee, 554.

Drysdale, C. W., writiugs: Bancroft, 37 ; Williams, 1050.

Eskers, Rochester district, New York: Giles, 337.

Glacial geology, northeastern North America : Fairchild, 298.

Ground waters: Meinzer, 655.

Hague, Arnold, writings : Iddings, 467.

LeRoy, O. E., writings : Schofield, 825 .

Loughridge, R. H., writings: Smith, 872.

Maryland, Anne Arundel County: Little, 577.

Mexico: Aguilar, 5.

New Mexico, Raton Mesa region: Lee, 554.

Orcgon, Cascates: Smith, 884.

Petroleum, 1915: Burroughs, 128.

Petrology: Pirsson, 757.

Physiograpby: Lobeck, 580.

Physiographic geology: Gregory, 367.

Purdue, A. H., writings: Ashley, 22.

Quicksilver: Bradley, 98.

Raton Mesa region; Colorado-New Mexico: Lee, 554.

Sand: Flopkins, 451.

San Lorenzo series, California : Clark, 172.

Seely, H. M. writings: Perkins, 750.

Serpentine, origin: Benson, 63.

Tungsteì : TIartmann, 407.

Wisconsin, southeastern: Alden, 8 .

Wyoming: Bovee, s6.

Biography.

Bell, Robert : Camsell, 152.

Brown, A. P.: Penrose, 749; Wherry, 1022.

Cairnes, D. D. : Camsell, 151

Clark, W. B. : Clarke, 186; Mathews, 629.

Drysdale, C. W.: Bancroft, 37 ; Williams, 1050.

Eastman, C. R. : Dean, 239.

Gratacap, L. P. : I Iunz, 540 ; Stanton, 902.

Gilbert, G. K. : Daris, 238; Fairehild, 300.

Hagne, Arnold: Iddings, 4.67.

Finde, G. J.: O'Connell, 716.

Irving, J. D. : Kemp, 501, 502 ; Lindgren, 573, 574.

LeRoy, O. 1.: : Schofield, 825 .

Loughridge, R. H. : Smith, 872.

I'urdue, A. H.: Ashley, 22; Glenn, 339.

Hussell, I. C. : Lane, 574.

Seely, H. M. : Perkins, 750.

Van Hise, C. R. : Berkey, 67 ; Chamberlin, 165 ; Anon., 1098.
Biography-Continued.

Williston, S. W.: Brown, 108; Osborn, 724.

Williams, H. S.: Schuchert, S32 ; Weller, 1012.

Birds. See Aves.

Bismuth.

General: Ujmpleby, 964, 965.

Bituminous rock.

General : Northrop, 713.

Bivalves. Sce L'elecypoda.

Borax.

California: Yale and Gale, 1053.

Death Valley: Young, 1086.

Borings.

Alberta, southern: Dowling, 262.

Arkansas, sonthwestern: Miller and Purdue, 679.

Deep wells, Pennsylvania and Test Virginia: White, 1035, 1036.

Kansas, central: Perrine, 751.

Louisiana: Deussen, 251.

Missouri, Belton area: Wilson, 1057.

Greene County: Shepard, 860.

Jackson County : McCourt et al., 606.

Oklahoma : Aurin, 27, 28.

Pennsylvania, McDonald : White, 10:33.

West Virginia, Barbour County : Regre. and reets, 778.

Clarksburg: White, 1033.

Upshur County : Reger and Yeets, 778.

Boulders.

New York, Ithaca, region: Fon Eugeln, 983.

Botany, fossil. See Palcobotany.

\section{British Columbia.}

Economic.

General: Robertson, 796.

Building and ornamental stones: Parks, 743.

Coal, Crowsnest area: Rose, 806.

Flathead area: Rose, 806.

Copper, Indian River, Vancouver division : Camsell, 149.

Crowsnest area: Rose, 806 .

Diatomaceous eartb, clay and magnesite, Pacific Great Eastern Railway : Camsell, 150.

Epsomite lake: Jenkins, 475.

Flathead area: Rose, 806.

Hazelton district: O'Neill, 720 .

Mining industry, 1917: Robertson, 796.

Slocan district: Bancroft, 38.

Squamish-Lillooet : Camsell, $14 S$.

Telkwa district: Dolmage, 260.

Dynamic and structural.

Yoho Glacier, motion, 1916-1.7; Wheeler, 1017.

Physiographic.

Fipsomite lake: Jenkins, 475.

Vancolver area: Purwash, 135. 
British .Columbia-Continued.

Stratigraphic.

Crowsnest area: Rose, 806.

Flathead area: Rose, 806.

Graham Island: Mackenzie, 614.

Hazelton district: O'Neill, 720.

Slocan district: Bancroft, 38 .

Squamish-Lillooet: Camsell, 148.

Telkwa district: Dolmage, 260.

Vancouver area: Burwash, 135.

Whitemans Pass section: Drysdale and Burling, 268.

Mineralogy.

Cerusite: Thomson, 945.

Salmo: Ledoux and Walker, 550.

Petrology.

Vancouver area: Burwash, 135.

Bromine.

General : Stone, 922.

Bryozoa.

Costa Rica, Miocene: Canu and Bassler, 153.

Cyclostomata, principles of classification: Canu and Bassler, 154.

Panama Canal Zone: Canu and Bassler, 153.

Building stone. See also Granite; Limestone; Sandstone; Stone.

British Columbla: Parks, 743.

Saltsburg sandștone: Brown, 110.

\section{Cadmium.}

General : Siebenthal, 865.

Calcite, solubility in sea-water: Wells, 1013.

Calcite brucite rocks, origin : Rogers, 799.

Calcium chloride.

General: Stone, 922.

Calico district, California : Palmer, 734.

\section{Callfornia.}

Gencral.

Catalog of publications of State Mining Bureau : Boalich, 82.

Lconomic.

Antimony: Boalich and Castello, 84.

Borax: Yale and Gale, 1083.

Chromium : Boalich, 81 ; Bradley et al., 100.

Calico district, San Bernardino County : Palmer, 734.

Death Valley: Young, 1086.

Engels deposits: Graton and McLaughlin, 362 .

Graphite: Boalich and Castello, 84.

Inyo Range and eastern slope of southern Sierra Nevada: Knopf, 527.

Manganese: Boalich, 81; Bradley et al., 100 ; Louderback, 585.

Mineral productiou, 1917 : Bradley, 99. Molybdenum : Boalich and Castello, \$3. Nickel : Boalich and Castello, 84. Oil prospects, Salinas Valley-Parkfield district: English.

Potash: Boalich and Castello, 84.

\section{California-Continued.}

Economic-Continued.

Quicksilver: Bradley, 98.

Strontianite, Barstow, San Bernardino County : Knopf, 530.

Strontium : Boalich and Castello, 84.

Tin : Boalich and Castello, 84 .

Tungsten: Boalich and Castello, s3.

Vanadium: Boalich and Castello, 83.

Dynamic and structural.

Earthquakes: Mulholland, 703.

1917: Palmer, 731.

registration, 1917 : Davis, 231.

San Jacinto, April 21, 1918: Rolfe and Strong, 805; Townley, 953.

aftershocks: Hamlin, 394.

southern California: Hamlin, 393; Wood, 1075 .

Fault system, San Jacinto region : Arnold, 21:

Franciscan sandstone, origin: Davis, 230.

Lassen Feak, eruptions: Sapper, \$15.

Sierra Nevada, glacial denudation : Muir, 702.

Physiographic.

Inyo Range and eastern slope of southern Sierra Nevada: Knopf, 527.

San Jacinto region: Arnold, 21.

Sierra Nevada, glacial denudation: Muir, 702.

Stratigraphic.

Calico district, San Bernardino. County : Palmer, 734.

Franciscan sandstone :f Dạis, 230.

Glaciation, Sierra Nevada- Knopf, 527.

Inyo County, geologifgmap: Waring, 991.

Inyo Range: Kirk, 519.;

Inyo, Range and eastern slope of southern Sierra Nevada: Knopf, 527.

Meganos group, Eocene: Clark, 171.

Oligocene: Clark and Arnold, 173.

Salinas Valley-Parkfield district: English, 294.

San Lorenzo series : Clark, 172.

Santa Inez Mountains, Santa Barbara County: Hawley, 415.

Tehon formations: Dickerson, 255.

Vaqueros formation: Loel, $\mathbf{5 8 1}$.

Paleontology

Bautista Creek fauna : Frick, 321.

Carrizo Creek fauna: Dickerson, 253.

Pleistocene fauna, Hawver Cave: Stock, 917.

Rancho La Brea, Felis daggeti: Merriam, 659 .

San Lorenzo series: Clark, 172.

Tropitidae, Triassic: Smith, 877.

Petrology.

Calcite-brucite rocks, origin: Rogers, 799 .

Franciscan sandstone: Davis, $\cdot 23 \%$.

Radiolarian cherts of Franciscan group : Davis, 232. 
California-Continued.

Mineralogy.

Christobalite: Rogers, $79 \mathrm{~s}$.

Periclase, Riverside: Rogers, 799.

Ulexite, Lang: Fushag, 318.

\section{Cambrian.}

stratigraphy.

Arizona, Grand Canyon: Schuchert, 829.

California, Inyo Range: Kirk, $\mathbf{5 1 9}$.

Georgia, Appalachian Valley: Schearer, 858

Idaho, southeastern : Schultz, S33.

Missouri : Branson, 102.

barite districts: Tarr, 932 .

Greene County : Shepard, 860

Montana, Garnet Range: Pardee, 738. northeastern : Collier, 200.

Pennsylvania, Blair and Huntinglon counties section: Butts, 142.

South Dakota, Black Hills region: Darton, 228 .

Texas, trans-Pecos front range: Baker and Bowman, 32

Virginia, Shenandoah Valley: Hewett et al., 433.

Wisconsin, southeastern : Alden, 8.

Wyoming, western: Blackwelder, 76 ; Schultz, 833.

\section{Paleontology}

Trilobites, appendages: Walcott, 988 .

Camp Custer region, Michigan: Leverett, 567.

Camp Devens areä, Massachusetts: Atwood, 26.

Camp Dodge area, Iowa: Lees and Alden, $557 \%$ bs

Camp Gordon airet;: Georgia: Matthes, 638.

Camp Grant quadrangle: Anon., 1905.

(amp Mills regiố, 'Long Island: Alden, 10.

Camp McClellan, Anniston quadrangle, Alabama: Matthes, 637.

Camp Pike region, Arkansas: Stephenson and Miser, 910.

Camp Sherman area, Ohio: Campbell, 147.

Camp Taylor region, Kentucky : Butts, 141.

liamp Upton region, New York: Alden, 9.

Canada (general). See also names of provinces.

Economic.

General : Malcolm, 616.

Clay : Keele, 498.

Fuel analyses: Stansfield and Nicolls, 899.

Gold in pre-Cambrian deposits, origin : Wallace, 989.

Graphite: Spence: 893 .

Mincral production, 1916: McLeish, 613.

Mineral resources: Malcolm, 616 .

Mineral waters: Elworthy, 282.

Mines Branch, report, 1917: Haanel, 384.

Mrothding sands: Cole, 193.

Road materials: Reinecks, 782.

Sandstone: Cole, 194.

Shale: Keele, 498.
Canada (general) - Continued.

stratigraphic.

Cordillera : Burling, 126.

Pre-Cambrian correlation and nomenclature: Wilson, 1060.

\section{Canal Zone. See Panama.}

Cannel coal, United States: Ashley, 23.

\section{Carboniferous.}

Stratigraphy.

Alaska, Gravina and Revillagigedo islands: Chapin, 167.

Nelchina-Susitna region: Chapin, 168.

Amsden formation, Wind River Mountains, Wyoming: Branson and Gregor, 103.

Arizona, Grand Canyon: Schuchert, 828.

British Columbia, Crowsnest and Flathead areas: Rose, 806.

Vancouver area: Burwash, 135.

California, Inyo Range: Krirk, 519.

Chester series: Ulrich, 962.

Idaho, southeastern: Schultz, 833.

Illinois, Starved Rock State l'ark: Cady, 143

Kansas: Moore and Haynes, 697.

central: Perrine, 751.

Kentucky, Shawnectown quadrangle: Lee, 552.

western: Butts, 140

Chester series: Ulrich, 962 .

Kinderhook, lower: Branson, 101.

Mississippian formations, western Kentucky : Butts, 140.

Mississippi Valley: Van Tuyl, 972. .

Missouri : Branson, 102.

Belton area: Wilson, 1057.

Greene County : Shepard, 860.

Jackson County, McCourt et al.,606.

Montana, Birch Creek-Sun River region : Stebinger, 905 .

Garnet Range : Pardee, 738.

northeastern : Collier, 200.

southwestern: Condit, 202.

Kansas, Fort Scott-Boone interval: Berger, 64.

Oklahoma: Auriu, 27; Cullen, 213; Perry, 752.

Osage County : Greene, 363.

Osage Reservation: Bowen, 89, 90, 91; Clark, 174 ; Emery, 287 ; Feald, 423 ; Heald and Mather, 425 ; Hopkins, 454 ; Lloyd and Mather, 579; Ross, 807; Winchester et al., 1067.

Pawhuska quadrangle: Heald, 424.

Red Beds: Ohern, 718.

Pennsylvania, Blair and Huntingdon counties section: Butts, 142.

Permo-Carboniferous colrelation: Case, 156.

Red Beds, origin : Knight, 526 .

Rhode Island: Hawkins, 412.

South Dakota, Black IIills region : Darton, 228. 
Carboniferous-Continued.

Stratigraphy-Continued.

Texas, Colorado coal feld : Drake, 266.

Glass Mountains: Udden, 959 .

north-central : Kempher, 504.

Rumnels County: Beede and Waite, 59.

trans-Pecos front range: Baker and Bowman, 32.

Wise County: Böse, 85.

Utah, Green River desert: Emery, $28 s$.

Uinta Mountains: Schultz, 834.

Virginia, Buchanan County: 'Hinds, 439.

Washington, Colville Indian Reservation: Pardee, $\mathbf{7 4 1 .}$

West Virginia, Barbour County : Reger and Teets, 778.

Upshur County: Reger and Teets, 778.

Wyoming, western: Blackwelder, 76; Condit, 202 ; Schultz, 833.

Paleontology.

Amsden formation, Wind River Mountains, Wyoming: Branson and Greger, 103.

Chester series: Uilrich, 962.

Conemaugh and Pottsville faunas, West Virginia: Price, 767.

Kentucky, western, Chester series: Butts, 140; Ulrich, 962.

Cartography. See also Maps.

Texas, geological mapping: Udden, 958.

\section{Caves.}

Tennessee: Bailey, 31.

Cement materials.

General : Bowles, 95.

United States: Burchard, 123.

Central America, See also Costa Rica; Stratigraphic. Guatemala, etc.

Tertiary, correlation: Vaughan, 979.

Cetacea. See Mammalia.

Changes of level. Sce also Beaches; Shore lines; Terraces.

Central. America: Powers, 764.

Glacial depression and postglacial uplift of northeastern America: Fairchild, 299.

Massachusetts, Boston, postglacial: Shimer, 862 .

Porto Rico: Mitchell, 681.

Postglacial continental uplift: Fairchild, 296, 297, 298.

Saginaw basin: Leverett, 568 .

Subsidence of reef-encircled islands : Davis, 237.

Cbemical analyses. See list, p. 127.

Chemical deposits of the sea: Vaughan, 977.

Chert

General: Price, 768.

Mississippian : Barton, 44.
Chert-Continued.

Origin: Barton, 44; Davis, 232; Van Tuyl, 971.

Missouri: Dean, 240.

Radiolarian cherts of Franciscan group : Davis, 232.

Chester series: Ulrich, 962.

Chromite.

General: Diller, 257 ; Williams, 1049.

Canada: Malcolm, 616.

Chromium.

California: Boalich, 81 ; Bradley et al., 100.

Cycadeoid wood structure: Wieland, 104.

Classification.

Ore deposits: Tovote, 952.

clay. See also Fire clay.

General : Middleton, 669.

British Columbia, Pacific Great Eastern Railway : Camsell, 150.

Canada : Keele, 498.

Mánitoba, Swan River valley: Johnston, $\cdot 484$.

Nebraska: Barbour, 39.

Saskatchewan, southern: Davis, 233. Climate, geologic. See Paleoclinatology.

Climatic types of sediments: Blackwelder, 74.

Coal. See also Anthracite; Lignite.

General: Gilbert and Pogue, 334; Lesher, 563.

Cannel coal, United Statés: Ashley, 23.

Fossil fuels, interrelations: Stevenson, 913. $1971 \%$

Origin, cannel coai' Ashley, 23.

British Columbia, ${ }^{\text {int }}$ Crowsnest and Flathead areas Rose, 806.

Colorado, Front Range: Whiteside, 1038.

Yampa field: Weston, 1016.

Idaho, southeastern: Schultz, 833.

Kentucky, Letcher County: Crider, 211.

Shawneetown quadrangle: Lee, 552.

Texas, Colorado coal field: Drake, 266.

Webb County, Santo Tomas cannel coal: Ashley, 24.

Utah, Morgan County, Lost Creek field : Clark, $\mathbf{1 7 5}$.

Virginia, Buchanan County: Hinds, 439.

West Virginia, Barbour County: Reger and Teets, 778.

Upshur County: Reger and Teets, 778.

Wyoming, western: Schultz, 833.

Coal measures. See Carboniferous:

Coal seams, spore-exines of : Thiessen, 939 .

Cobalt.

rq

Lateritic ore deposits: Miller, 672. 
Colorado.

Economic.

Carnotite deposits, southwestern Colorado: Kithil and Davis, 522.

Coal, Front Range: Whiteside, 1038.

Gold, silver, copper; lead, and zinc in 1916: Henderson, 428.

Molybdenum, Climax: Brown and Hayward, 109 ; Haley, 391.

Summit County: Holland, 445.

Oil possibilities: Ziegler, 1091.

Oil shales: Adkinson, 4; Alderson, 11 ; Ziegler, 1089.

northwestern Colorado: Chase, 169 ; Hoskin, 459.

Pyrite, Leadville: Lee, 551.

Telluride district: Wolf, 1073.

Tomichi district, Gunnison County : Dick, 252.

Uranium-vanadium ores, origin : Notestein, 714.

Yampa coal field: Weston, 1016.

Zinc, Leadville: Loughlin, 590.

Dynamic and structural.

General : Darton, 227.

Erosion of canyon bottoms : Duce, 269.

- Physiographic.

Estes Park, glacial moraines : Wooster, 1077.

Rocky Mountain National Park, Colorado: Lee, 553.

Stratigraphic.

General: Darton, 227 ; Ziegler, 1901.

Glaciation, San Juan Mountains: Atwogd, 25.

Green Rirer formation: Winchester, $1066 \cdot n$

Morrison, formation, age: Schuchert, 830.

North Park: Finlay, 311.

Raton Mesa region: Lee, $\mathbf{5 5 4}$.

Rocky Mountain National Park, Colorado: Lee, 553.

San Juan Mountains: Atwood, 25.

Tiffany beds: Granger, 357.

Paleontology.

Beetles, Tertiary : Cockerell, 189.

San Juan Basin, Mammalia : Granger, 357.

Tiffany beds fauna: Metthew and Granger, 649.

Tillodont skull, Huerfano Basin, Colorado : Granger, 358.

Vermejo and Raton floras: Knowiton, 535.

Zanycterís (Paleocene bat), Ignacio: Matthew, 639.

Petrology.

Cripple Creek : Alling, 17.

Mineralogy. .

Leadville, zinc-ore minerals: Loughlin, 590.

Pyrite, Ibex mines: Kunz, 539.

Congresses. See Associations.
Connecticut.

Stratigraphic.

Cedar Mountain trap ridge: Daris, 236.

Mineralogy.

Cronstedtite, Trumbull Township: Hoadley, 441.

Continental clastics, characteristics: Blackwelder, 74.

Continental shelf, origin : Cotton, 209.

Copper.

General: Butler, 137.

Alaska : Martin, 623.

Lake Clark-central Kuskokwim region: Smith, 878 .

Arizona : Finlay; 312.

Bisbee, Sacramento Hill: De Kalh, 248.

Jerome district: Finlay, 313; Provot, 769; Rice 7S3; Rickard, 789.

Pima County, Ajo: De Kalh, 247.

Britișh Columbia, Indian Ri :er: Camsell, 149.

Telkwa district: Dolmage, 260.

Central States: Dunlop and Butler, 274.

Colorado: Henderson, 428.

Cuba, Oriente: Emerson, 284.

Eastern States: Hill, 436.

Idaho: Gerry, 331.

Manitoba, Schist Lake district : Bruce, 113.

Nevada: Heikes, 427.

Clark County, Yellow Pine district: Hale, 389.

Yerington district: Knopf, 528.

Ontario, northwestern: Parsons, 746.

Sudbury: Roberts and Longyear, 791, 792, 793.

Utah: Heikes, 426.

Tooele County: Kemp and Billingsley, 503.

Washington: Gerry, 331.

Coral islands and reofs.

Hawaiian Islands: MacCaughey, 604.

Origin : Davis, 234.

Subsidence of reef-encircled islands : Davis, 237.

Corals. See Anthozoa.

Correlation. See Stratigraphic.

Cosna-Nowitna. region, Alaska : Eakin, 275.

Costa Rica.

Economic.

Manganese: Spilsbury, 896.

Dynamic and structural.

Irazâ, eruptions, 1917-18: Calvert, 145.

Paleontology.

Bryozoa, Miocene: Canu and Bassler, 153.

Echini:- Jackson, 468. 
Crésaceous.

stratigraphy.

Aliabama: Hager, 387.

Aberta, central: Allan, 12.

Peace River section: McLearn, 610.

Viking field: Slipper, 871.

Alaska, Chitina Valley : Moffit, 683 .

Nelchina-Susitna region: Chapin, 168.

Arkansals, Caddo Gap and De Queen quadrangles: Miser and Furdue, 680 .

southwestern: Miller and Purdue, 679.

British Columbia, Crowsnest and Flathead areas: Rose, 806 .

Vancouver area: Burwash, 135.

California, Salinas Valley: English, 294.

Colorado: Ziegler, 1.091.

Raton Mesa region: Lee, 554.

Comanchean, central Kansas: 'Twenhofel, 956.

Cuba: De Golyer, 241.; Hayes, Vaughan, and Spencer, 421.

Great Plains : Darton, 227.

Idaho, southeastern: Schultz, 833.

Kansas: Moore and Haynes, 697.

central : Perrine, $\mathbf{7 5 1 .}$

Maryland, Anne Arundel County : Little, 577.

Mexico, Tampico embayment area : Dumble, 271.

Montana, Birch Creek-Sun River region: Stebinger, 905 .

Garnet Range: Pardee, 738.

Lake Basin field: Haucock, 395.

Musselshell Valley: Bowen, 92.

northeastern : Collier, 200.

southwestern : Condit, 202.

Nevada, Yerington district: Knopf, 528.

New Mexico, Raton Mesa region: Lee, 554.

Northwest Territory, Great Slave Lake region: Cameron, 146.

Oklahoma, southern: Stephenson, 909.

Oregon, Cascades: Smith, 884.

Porto Rico, Coamo-Guayama region: Hodge, 443.

San Juan district: Semmes, 845.

Saskitchewan, șouthern: Davis, 233.

South Dakota, Black Hills region: Darton, 228.

Texas, Camp Bowie area : Shuler, 864. Colorado coal field: Drake, 266. northeastern: Stephenson, 909.

Runnels County: Beede and Waite, 59.

San Antonio area : Muir, 700.

trans-Pecos front range: Baker and Bowman, 32.

Val Verde Co.: Roberts and Nash, 794.

Wise County: Böse, 85.

Utah, Green River desert: Emery, 288.

Cretaceous-Continued.

Stratigraphy-Continued.

Wyoming, Hanna Basin : Bowen, 88.

Fark County: Moody and Taliaferro, 688 .

Salt Creek oil field: Wegemann, 1010.

western: Schultz, 833.

Palcontology.

Alberta, selachian: Lambe, $\mathbf{5 4 4}$.

Stegosaurus: Lambe, $\mathbf{5 4 5}$.

Colorado, Vermejo flora: Knowlton, 535.

Dakota sandstone, leaves: Gress, 371.

New Mexico, Vermejo flora: Enowlton, 535.

Texas, Camp Bowie area : Shuler, 864.

Crinoidea, See also Echinodermata.

Camarocrinus: Cockerell, 190.

Embryocrinus problematicus: Hudson, 465.

Isocrinus, Triassic, Alaska: Bather, 56.

Mysticocrinus, Silurian, Indiana: Springer, 897.

Crustacea.

Balanidae, phylogeny: Ruedemann, $\varepsilon 09$.

Lepadidae, derivation: Clarke, 187.

Panama Canal Zone, Cirripedia: Pilsbry, 756.

Decapoda: Rathbun, $\mathbf{7 7 4}$.

Cristobalite and tridymite, melting points: Ferguson and Merwin, 308.

Cryolite.

General: Burchard, 124.

Cryptogams. See Paleobotany.

Crystallography.

Cerusite, British Coltimbia: Ledoux and Walker, 550; Thomson, 945.

Classes of crystals : Wherry, 1026.

Crystal problems, solution: Blake, 79 .

Etching figures of the dihexagonal alternating type: Honess, 448.

Geometrical crystallography: Butler, 138.

Manual of geometrical crystallography : Butler, 139.

Polyhedron of the diamond lattice: Adams, 2.

Pyrolusite, Virginia: Watson, 1005.

Quartz crystals, Centerdale, Rhode Island: Hawkins, 41.0.

Quebec, Megantic County: Poitevin and Grabam, 761.

Teaching elementary crystallography : rogue, 759.

Tourmaline, Macdonald Island, Baffin Land: Ledoux, 549.

Cuba. Sce also Trest Indies.

Economic.

Cobre, Oriente: Emerson, 284.

Iron: Weld, 1011.

Mineral resources: Montoulieu, 684.

Petroleum fields: DeGolyer, 241. 
Cuba-Continued.

lhysiographic.

General: Hayes, Vaughan, aud Spencer, 421.

Stratioraphic.

General: Hayes, Vaughan, and Spencer, 421 .

Petroleum fields: DeGolyer, 241.

raleontolog!y.

Mammalia: Allen, 1.3.

Cystoidea.

Megalocnus : Matthew, 643 .

Agelacrinites and Streptaster, Richmond group: Williams, 1053.

Agelacrinites rectiradiatus, Richmond group, Ohio: Shideler, 861.

Decomposition of rocks. See Weathering.

Jecp wells: White, 1036.

Deiormation of rocks: Adams, 3.

Delaware.

Underground water.

General: Clark et al., 179.

Deltas.

Desert deltas, rate of growth: Keyes, 506.

Valdez, Alaska: Johnson, 479.

Denudation. Sce Erosion.

Deposition. S'ee Sedimentation.

Deposition of ores. See Ore deposits, origin.

Dosert deltas, rate of growth: Feyes, 506 . Desert depressions, origin: Hobbs, 442.

Deserts.

Erosional and degradational processes: Hobbs, 442.

Desiccation of the earth: Ton Herrmann, 985.

\section{Devonian.}

Stratigraphy.

Alaska, Cosna-Nowitna region: Eakin, 275.

Gravina and Revillagigedo islands: Chapin, 167.

Alberta, Peace River section : McLearn, 610.

Rritisb Columbia, Crowsnest and Flathend areas: Rose, 806 .

California, Inyo Range: Kirk, 510.

Genesee shale and Tully limestone, relationship: Grabau, $\mathbf{3 5 5}$.

Missouri: Branson, 102.

Greene County: Shepard, 860.

Montana, Garnet Range: Pardec, 738.

New York, central: Taber, 926 .

Northwest Territory, Great Slave Lake region: Cameron, 146.

lennsylvania, Blair. and Funtingdon counties section: Butts, 142.

Quebec, Gaspe County, Lemieux : Mailhiot, 615 .

Tennessee, western: Dunbar, 273.

Texas, trás-recos front range: Baker and Bowman, 32 .

Tully limestone and Genesee shale, relationsbip : Grabau, 355.
Devonian-Continued.

strutigraphy-Continued.

West Virginia, Barbour County: Reger and Teets, 778 .

Wisconsin, southeastern: Alden, 8 .

Wyoming, western: Blackwelder, 76; Schultz, 833

Paleontology.

Michigan, Detroit River series: Stauffer, 903 .

Ontario, Onondaga limestone: Stauffer, 903

Tennessee, western : Dunbar, 273.

Tully fauna: Grabau, 355.

Diastrophism.

General: Schuchert, 827.

Periodic, production of : Chamberlin, 164.

Dikes.

New York, Adirondacks : Miller, 677.

Utah, Santaquin and Mount Nebo region: Loughlin, 589.

Dinosauria. See Reptilia.

Dip, projection of, graphic method : l'almer, 732.

Dips, anomalous: Shaw, 857 .

Diplocaulus, structure and relationships: Douthitt, 261.

Dislocation. Sec Faulting.

Distribution. Sce Geographic distribution.

District of Columbia.

Underground water.

General : Clark et al,. 179.

Dolomite, formation of: Skeats, 869 .

Dolomitization, depth of : Van 'Juyl, 972.

Drainage changes.

Kansas, Kaw Iake area : Todd, 048 .

Montana, northeastern: Collier, 200.

New York, Tompkins County: Haus$\operatorname{man}, 409$.

Ohio, Camp Sherman region: Campbell, 147.

Drift.

Eolian lonss: Todd, 949 .

Dryness of sandstione beds, cause : Johnson, 482 .

Duluth gabbro: Grout, 380 .

Dust fall, March 9, 1918: Winchell and Miller, 1062.

Dynamic and structural (general). For regional, see the various States. See also list of subject headings on p. 85 .

General: Schuchert, 827.

Continental shelf, origin: Cotton, 209. Desiceation of the earth: Von Herrmann, 985 .

Dolomite, formation of: Skeats, 869 .

Dust falls, 1918: Wiuchell and Miller, 1062,1063 .

Experiments relating to continental deformation: Chamberlin and Richards, 162.

Indicia of dip in rocks: Logan, 583.

Laccolithic intrusion, inechanics of : Keyes, 507. 
Dynamic and structural (general)-Contd. Mechanics of vein formation: Taber, 927.

Marginal sedimentation : Cotton, 209. Marine limestone strata, dip: Mather, 626.

Red Beds, origin: Knight, 526.

Ring structures in silica: Stansfield, 901.

Salt, separation from saline water and mud: Kindle, $\mathbf{5 1 6}$.

Subsidence of reef-encircled islands: Davis, 237.

Travertine, formation: Emig, 289.

Vein formation: Taber, 927.

central New York: Taber, 926.

Educational. See also Textbooks.

Geology in education: Salisbury, 812.

Preparation of a report: Van Ingen, 968.

Teaching elementary crystallography: Pogue, 759.

Earth, genesis of. See also Dynamic and structural (general).

General : Barrell, 41 ; Chamberlin, 163. Faceted form of a collapsing geoid : Keyes, 508.

Earth, temperature.

Boring, deep: Van Orstrand, 970.

Oil-field temperatures: DeGolyer, 244.

Pennsylvania, McDonald well: White, 1033.

West Virginia, Clarksburg well : White, 1033.

Farth movements. See Landslides.

Earth structure, growth of knowledge of: Barrell, 42.

Earthquakes. See also Selsmology.

California: Mulbolland, 703.

1917 : Palmer, 731.

registration, 1917 : Davis, 231.

San Jacinto: Rolfe and Strong, 805; Townley, 953.

April 21, 1918, aftershocks: Hamlin, 394.

southern: Hamlin, 393; Wood, 1075.

Effects in mines: Staunton, 904.

Guatemala, December, 1917-January, 1918 : Anon., 1094.

Mexico, Sonora : MacDonald, 608.

Virginia, April 9, 1918 : Watson, 1006.

Echinodermata. See Asteroidea; Blastol-

dea ; Crinoidea; Cystoidea; Echinoidea.

\section{Echinoidea.}

Costa Rica: Jackson, 468.

Geologic range and evolution: Kew, 514.

Panama Canal Zone: Jackson, 468.

Economic (general). For regional see under the various states. See also Ore deposits origin, and the particular products.

Fluorine in sericitization: Paige P.M Steiger, 729 .
Economic (general)-Continued.

Ore deposits of the Southwest: Tovote, 952 .

Principles : Emmons, 292.

Review of 1917: Knopf, 531.

Tests for metals in minerals : Fansett, 301.

Text-book: Emmons, 292.

War minerals: Spurr, 898.

Emery.

Virginia: Watson and Steiger, $10^{n}$ s. Focene. see Tertiary.

Eolian action. See Windwork.

Ensomite.

British Columbia: Jenkins, 475.

Washington: Jenkins, 475.

Erosion.

Canyon bottoms, Colorado: Duce, 260.

Potholes: Elston, 281.

Eruptive rocks. See Igneous and volcanic rocks.

Eskers.

New York, Rochester district: Giles, 337.

Origin: Giles, 337.

Essays. See Addresses.

Eurypterida: O'Connell, $\mathbf{7 1 5}$.

Evolution.

General: Lull, 599; Mather, 623: Schuchert, 827 .

Organic evolution: Lull, 597.

Paleontology of arrested evolution : Reudemann, 808.

Vertebrae, evolution: Williston, 105.5.

Experiment in geology : Adams, 3.

Experimental investigations.

Experiments relating to continental deformation: Chamberlin and Richards, 162.

Failure of cavities in crystals and rocks under pressure: Bridsman, 104.

Low-angle faulting: Chamberlin and Miller, 161.

Salt solutions: Kindle, 516.

Faceted form of a collapsing geoid: Keyes, 508.

Faulting.

California, San Jacinto region: Arnold, 21.

Indiana, Mount Carmel: Logan, 582.

Low-angle faulting: Chamberlin and Miller, 161.

Mechanics of great overthrusts : Chamberlin, 160.

Overthrust faulting: Chamberlin and Miller, 161.

Wyoming, Hart Mountain overthrust : Dake, 218.

Feldspar.

General: Katz, 494.

Finger Lake basins, origin: Von Engeln, 984.

E.ishes. See Pisces.

Vissures. Sce Faulting. 
Florida,

General.

Survey reports: Sellards, 839.

Vero, climatic conditions: Wieland, 1046.

Economic.

Mineral production, 1917: Sellards, 841.

Western Florida: Sellards and Hunter, 842, 843.

Stratigraphic.

Tertiary, correlation: Vaughan, 979.

Western Florida: Sellards and Gunter, 842,843 .

Paleontology.

Bird fossils: Shufelt, $\$ 63$.

Foraminifera, Coastal Plain: Cushman, 215 .

Human remains, Vero: Hay, 418, 420.

Mollusca, DeLand, Volusia County: Mansfield, 619.

Tapir, Pleistocene, Vero: Sellards, 840.

Vero, Pleistocene: Nelson, 707.

Afineralogy.

Meteorite, Eustis, Lake County : Merrill, 662.

Vivianite, color change: Watson, 1004.

Plant City: Watson and Gooch, 1007.

Fluorine in sericitization: Paige and Steiger, 729 .

Fluorite, optical, southern Illinois: Pogue, 758.

Fluorspar.

General: Burchard, 124.

\section{Footprints.}

Arizona, Grand Canyon: Lull, 600.

\section{Foraminifera.}

P'unama Canal zone: Cushman, 216, 217.

Pliocene and Miocene, Coastal Plain : Cushman, 215.

Fossil fuels, interrelations: Stevenson, 913. Fossilization.

Ring structures in silica: Stansfield, 901.

Wood replaced by calcite: Greenland, 364.

I'ossils. Sec Paleontology.

Frauciscan sandstone: Davis, 230.

Fuller's earth.

General: Middleton, 670.

Gas. See Natural gas.

Gastropoda. See also Mollusca.

Cretaceous, generic names: Wade, 986 .

Lymnaea : Hannibal, 398.

Genesee sinale and Tully limestone, relationsuip : Grabau, 355.

Genesis of ores. Sec Ore deposits, origin.

Geochemistry.

Carbon dioxide in water of Gulf of Mexico: IVells, 1015.

Chemical deposits of the sea: Vaughan, 977.
Geochemistry-Continued.

Fluorine in sericitization: Paige and Steiger, 729.

Gold, deposition in nature: Lenher, 562.

Inorganic constituents of crustacea : Clarke and Sulkover, 180.

Organic deposits of the sea: Vaughan, 977.

Uranium-vanadium ores, origin: Note. stein, 714.

Geodes.

Keokuk region: Wherry, 1021.

Geologic climate. See l'alroclim:tology.

Geologic formations described. Sce list, p. 129.

Geologic history. See also Paleoclimatology ; Paleogeography.

Alaska, Chitina Valley: Moffit, 689.

Cosna-Nowitna region: Eakin, 27\%.

Nelchina-Susitna region: Chapin, 168.

Arizona, Jerome district: Provot, 769.

Colorado, Raton Mesa region : Lee, 554.

Rocky Mountain National Fark: Lee, 553.

Cuba: Haȳes, Vaughan, and Spencer, 421.

Florida, western: Sellards and Gunter, 842.

Georgia, Appalachian Valley : Shearer, 858.

Illinois, Starved Rock State Park: Cady, 143.

Jackson and Vicksburg deposits, Alabama and Mississippi: Cooke, 205.

Kansas: Moore and Faynes, 697.

crystalline rocks: Moore, 696.

Pleistocene: Todd, 947.

Maryland, Anne Arundel County : Littie, 577.

Massachusetts, Boston, postglacial: Shimer, 862.

Mexico, Tampico embayment area : Dumble, 271.

Mississippi, northern and central, Pliocene: Shaw, 850.

Missouri : Branson, 1.02.

barite districts: Tarr, 932 .

Jackson County : McCourt et al., 606.

Nevada, Reese River basin: Waring, 993.

Yerington district: Knopf, 528.

New Mexico, Raton Mesa region: Lee, 554.

Oklahoma, travertine deposits: Emig, 289.

Oregon, Cascades: Smith, 884.

Wallowa Mountains: Smitb, 886.

Rocky Mountains, southern, Mesozoic: Lee, 556.

Saskatchewan, Amisk Lake district: Bruce, 111. 
Geologic history-Continued.

Texas, trans-Pecos front range : Baker and Bowman, 32.

Washington, Big Bend region, glacial history: Meinzer, 656 .

Colville Indian Reservation: Pardee, 741.

western: Leighton, 559 .

Wisconsin, southeastern, ..Pleistocene : Alden, 8.

Wyoming, Park County: Moody and Taliaferro, 688:

\section{Geologic maps.}

Alaska, Chitina Valley: Moffit, 683.

Cosna-Nowitna region: Eakin, 275. Gravina and Revillagigedo islands: Chapin, 167.

Lake Clark-central Kuskokwim region: Smith, 878.

Nelchina-Susitna region: Chapin, 168.

Arizona, Jerome district: Provot, 769.

Arkansas, Caddo Gap and De Queen quadrangles: Miser and Purdue, 680.

southwestern: Miser and I'urdue, 679.

British Columbia, Vancouver area: Burwash, 135.

Barbados: Craig, 210.

California, Barstow-Kramer region, San Bernardino County : Knopf, 530.

Bishop and Mount Goddard (part) quadrangles: Knopf, 527.

Inyo County: Waring, 991.

Mount Whitney, Olancha (part), and Ballarat (part) quadrangles: Knopf, 527.

Parkfield district: English, 294.

l'ley to oil district: English, 294.

quicksilver districts: Bradley, 98.

Salinas Valley, English, 294.

Colorado, Canon City coal field: Lee, 554.

Cuba: Hayes, Vaughan, and Spencer, 421.

Florida, western: Sellards and Gunter, 843 .

Georgia, Coastal Plain: Cooke and Shearer, 206.

Great Plains: Darton, 227.

Idaho, southeastern: Schultz, 833.

Illinois, north central : Cady, 143.

Starved Rock State Park: Cady, 143.

Kansas: Moore and Haynes, 697.

Camp Funston region : Moore, 695.

Kentucky : Sellier, 844.

Cieorgetown quadrangle: Miller,.671. Shawneetown quadrangle: Lee, 552. western: Butts, 140.

Maryland, Anne Arundel County: little, 577.

Michigan, surface geology: Leverett, 565.

Minesota, east central : Harder and Jolunston, 403.
Geologic maps-Continued.

Missouri, barite districts : Tarr, 932.

Jackson County: McCourt et al., 606.

Kansas City : McCourt et al., 606.

Montana, Birch Creek-Sun River region: Stebinger, 905 .

Garnet Range: Pardee, 738.

Lake Basin field: Hancock, 395.

Musselshell Valley: Bowen, 92.

northeastern: Collier, 200; Collier and Thom, 201.

Nevada, Reese River basin: Waring, 993.

Yerington district: Knopf, 528.

New Mexico, Grant County: Schwennesen, 836.

New York, Placid quadrangle, central part: Miller, 677.

North Dakota, Nesson anticline, Williams County : Collier, 199.

surface (Lake Agassiz): Leverett, 564.

Oklahoma: Aurin, 27 ; Snider, 888; White, 1031.

Osage Reservation: Bowen, .90, 91; Clark, 174 ; Emery, 287 ; Heald 423; Heald and Mather, 425; Hopkins, 454; Lloyd and Mather, 579 ; Ross, 807.

southern: Stephenson, 909.

Ontario: Hopkins, 456.

Dryden gold area, district of $\mathrm{Ke}$ nora: Thomson, 943.

Gauthier township: Burrows, 131.

Kowkash area: Hopkins, 455.

Long Lake district: Baker, 34 ; Burrows, 129.

Matachewan area: Burrows, 132.

northwestern, Mine Center region: Parsons, 746.

Slate Islands: Parsons, $\mathbf{7 4 5}$.

Toronto region: Coleman, 195.

Pennsylvania, Boyertown region : Jonas, 485.

Quebec, Gaspe County, Lemieux : Mailhiot, 61.5 .

Megantic Co.: Poitevin and Graham, 761.

Rhode Island: Hawkins, 412.

Saskatchewin, Amisk Lake district: Bruce, 111.

southern: Davis, 233.

South Dakota, Black Fills region, artesian conditions: Darton, 228.

Tennessee, Cleveland region: Stose and Schrader, 923.

Sweetwater region: Stose and Schrader, 923.

western: Dunbar, 273.

Texas, Colorado coal field: Drake, 266. north central: Hager, 388 .

northeastern : Stephenson, 909.

Runnels County: Beede and Waite, 59.

Val Verde Co.: Roberts and Nash, 794. 
Geologic - maps-Continued.

Utah, Clifton (Deep Creek) district: Kemp and Billingsley, 50 .

Green River desert: Emery, 288.

Morgan County, Lost Creek field : Clark, 175.

Uinta Mountains: Schulz, s:34.

Virginia, Buchanan County: Hinds, 439.

Washington, Colville Indian Reservation: Pardee, 741.

West Virginia : White et al., 1037.

Barbour County: Reger and Teets, 778.

Upshur County: Reger and Teets, 778.

Wisconsin, southeastern, surficial: Alden, 8.

Wyoming, Fark County, Sunshine: Moody and Taliaferro, 688.

Kock Springs uplift and Dry Lake dome: Trumbull, 955.

Sult Creek oil field: 1010.

western: Schultz, 833.

\section{Geologic time.}

General: Barrell, 40.

Goological surveys. See Surveys.

Geology and the public service: Smith, 873 .

Geomorphogeny. See Physiographic.

Geomorphology. See Physiographic.

\section{Geophysics.}

Calcite, solubility in sea water: Wells, 1013.

Failure of cavities in crystals and rocks under pressure: Bridgman, 104.

Melting points of cristobalite and tridymite: Ferguson and Merwin, 308.

Ternary system $\mathrm{MgO}-\mathrm{Al}_{2} \mathrm{O}_{3}-\mathrm{SiO}_{3}$ : Rankin and Merwin, 773.

\section{Georgia.}

Ecollomic.

Manganese: Anon., 1096.

Mineral resources: McCallie, 602.

rotash, Cartersville slates: Shearer, 858.

l'yrites deposits: Shearer and Hull, 859.

Slate: Shearer, s5s.

Physiographic.

Camp Gordon region: Matthes, 688.

suratigraphic.

Claiborne and Tackson deposits: Cooke and Shearer, 206.

Northern Georgia: Shearer and Hull, 859.

Slate deposits: Shearer, 858.

Tertiary, colrelation: Vaughan, 979.

\section{Glacial erosion.}

California, Sierra Nevada: Muir, 702.

Glacial geology. Śec also Quaternary.

General.

Glacial depression and postglacial uplift of northeastern America : Fairchild, 299.
Glacial geology-Continued.

General-Continued.

Till, character in southern Illinois: Shaw, 853.

Unity of Pleistocene glacial period: Wright, 1079.

Alaska, Nelchina-Susitna region: Chapin, 168.

Arctic l'egions: Muir, 701.

British Columbia, Vancouver area: Burwash, 135.

California, Sierra Nevada: Knopf, 527.

Colorado, Estes Park: Wooster, 1077.

Rocky Mountain National I'ark: Lee, 553.

San Juan Mountains : Atwood, 25.

Hawaii, Mount Kea: Bryan, 115.

Illinois, Chicago area : Wright, 1080.

Starved Rock State Park: Cady, 143.

Iowa, Crawford and Carroll counties: Kay, 497.

Kansas: Todd, 947.

Manitoba, Hudson Bay Railroad: Johnston, 483.

Wekusko Lake area : Alcock, 6 .

Michigan : Leverett, 565.

Camp Custer region: Leverett, 567.

Missouri : Branson, 1.02.

Jackson County: McCourt et al., 606.

New York, Camp Upton region: Alden, 9.

Catskill Mountains: Rich, 784.

Long Island, Camp Mills region : Alden, 10.

Rochester district: Giles, 337.

Northeastern North America: Fairchild, -298.

North Dakota: Leverett, 564.

Barnes County, eskers and kamos: Hard, 400.

Ohio, Camp Sherman region: Campbell, 147.

Ontario, Toronto region: Colcman, 195.

Quebec, Timiskaming County: Wilson, 1058.

Saginaw basin: Ijeverett, 568 .

Saskatchewan, southeastern: Stinsfield, 900 .

southern: Davis, 233.

Vermont, Wilmington area : Hubbard, 463.

Washington, Colville Indian Reservation: I'ardee, 741 .

western: reighton, 559 .

Wisconsin, southeastern: Alden, 8.

Glacial lakes, See also Beaches; Shore lines; Terraces.

Lake Agassiz: Leverett, 564.

Michigan: Jeverett, 565.

Superior basin : Leverett, 566.

Wisconsin, southeastern: Alden, 8.

Glacial period. Sce. Glacial geology. 
Glaciers.

Yoho Glacier, motion, 1916-17 : Wheeler, 1017.

Glass Mountains, Texas: Udden, 959.

Glass sand.

General : Fettke, 309.

Pennsylvania : Fettke, 309.

Glauconite in dolomite and limestone of

Missouri : Tarr, 931.

Gold.

General: McCaskey and Dunlop, 603. Deposition in nature: Lenher, 562.

Origin in Canadian pre-Cambrian deposits: Wallace, 989.

Placer deposits, United States: Janin, 471.

Alaska : Martin, 623.

Lake Clark-central Kuskokwim region: Smith, 878.

British Columbia, Slocan district: Bancroft, 38.

Colorado: Henderson, 428.

Eastern States: Hill, 436.

Idaho : Gerry, 331.

Manitoba, Star Lake area: Marshall, 622.

Wekusko Lake area : Alcock, 6, 7.

Montana, Garnet Range: Pardee, 738.

Nevada: Heikes, 427.

Clark County, Yellow Pine district: Hale, 389.

Tonopah: Bastin and Laney, 51.

Ontario, Benoit township: Burrows, 130.

Dryden gold area, district of $\mathrm{Ke}$ nora: Thomson, 943.

Gauthier township: Burrows, 131.

Kowkash area : Hopkins, 455.

Long Lake district: Baker, 34.

Matachewan area: Burrows, 132.

Rickard township: Hopkins, 456.

Quebec, Timiskaming County: Wilson, 1058.

Saskatchewan, Amisk Lake district: Bruce, 111.

Utah: Heikes, 426.

Washington: Gerry, 331.

Yukon: Cockfield, 191.

Government geologic surveys: Smith, 875. Grand Canyon. See Arizona.

Granite.

British Columbia: Parks, 743.

Graphite.

General : Ferguson, 307.

California: Boalich and Castello, 84.

Canada: Spence, 893.

New York, Adirondack Mountains: Alling, 16.

Origin: Alling, 16.

- Graptolite shales, depth at which formed : Grabau and O'Connell, 356.

Gravel.

Arkansas, Caddo Gap and De Queen quadrangles : Miser and Purdue, 680 .
Great Basin lakes, origin :. Keyes, 509.

Greenland.

Dynamic and structural.

Nivation and solifluction: Ekblaw, 279.

Stratigraphic.

Parker Snow Bay: Hovey, 461.

Guatemala.

Dynamic and structural.

Earthquake, December, 1917-January 1918: Anon., 1094.

Volcanoes: Sapper, 814.

Physiographic.

Eastern Guatemala: Powers, 764.

Stratigraphic.

Eastern Guatemala: Powers, 704.

Gypsum.

General : Stone, 921.

Haiti.

Stratigraphic.

General: Jones, 490.

Hawaiian Islands.

Dynamic and structural.

Formation of islands: MacCaughey. 604.

Volcanoes: Friedlaender, 322.

general : Jaggar, 469.

Kilauea, model: Daly, 224 ; Sayles, 819.

Stratigraphic.

Glaciation, Mount Kea: Bryan, 115.

History, philosophy, etc.

General : Schuchert, 831.

Earth structure, growth of knowledge of : Barrell, 42.

Experimental investigations: Adams, 3. Government geologic surveys: Smith, 875.

Mineralogy, 1818-1918: Ford, 317.

Petrology : Pirsson, 757.

Vertebrate paleontology: Lull, 601 .

Honduras.

Physiographic.

Northern Guatemala: Powers, 764.

Stratigraphic.

Northern Guatemala : Powers, 764.

Petrology.

Northwestern Honduras: Foye, 31.9.

Huronian. See Pre-Cambrian.

Ice age. See Glacial geology.

Ice ages (ancient).

Alaska, southeastern, Paleozoic: Kirk, 521.

Iceland spar, Montana: Parsons, 747.

Idaho.

Economic.

Antimony, central Idaho: Bell, 62.

Coeur d'Alene-district, Success mine: Hershey, 430 ; Moore, 699.

Gold, silver, copper, lead, and zinc, 1916 : Gerry, 331.

Mineral resources : Bell, 61.

Mining industry, 1916, 1917 : Bell, 60, 61. 
Idaho-Continued.

Economic-Continued.

Northern Idaho: Soper, 889.

Origin of western phosphates: Mansfield, 618 .

Phosphate and coal, southeastem Idaho: Schultz, 833.

Quicksilver, central Idaho: Bell, 62.

Southeastern Idaho: Schultz, 833.

Stratigraphic.

Southeastern Idaho: Schultz, 833.

raleontology.

Idaho formation fauna : Merriam, 661.

Mammalia, Idaho formation: Merriam, 657.

Physiographic.

Idaho peneplain, age: Lindgren, 575;

Mineralogy. Livingston, 578; Rich, 786, 787 .

Coeur d'Alene district: Shannon, 848.

Ilvaite, Owyhee County : Shannon, 847 .

Mullanite: Shannon, 846.

Idaho peneplain, age: Lindgren, 575 ; Livingston, $578 ;$ Rich, 786, 787.

Igneous and volcanic rocks. See also Intrusions; Magmas.

General.

Alkaline rocks, genesis: Daly, 225.

Convection, two-phase: Grout, 381.

Internal structures: Grout, 379,380 .

Quantitative classification: Washington, 998 .

Alaska, Chitina Valley: Overbeck, 727.

Cosna-Nowitna region: Eakin, 275.

Lake Clark-central Kuskokwim region: Smith, 878 .

Nelchina-Susitna region: Chapin, 168.

Arctic regions, Ellesmere and Grinuell linds: Foltedahl, 447.

Arizona, Jerome district: Provot, 769.

British Columbia, Vancouver area : Burwash, 135.

California, Inyo Range: Knopf, 527.

Cuba : DeGolyer, 241 ; Hayes, Vaughan, and Spencer, 421.

Haiti : Jones, 490.

Honduras, northwestern : Foye, 319.

Idaho, southeastern: Schultz, 833.

Manitoba, Wekusko Lake area: Alcock, 6.

Montana, Garnet Range : Pardee, 738. Musselshell Valley: Bowen, 92.

Minnesota: Bowles, $\mathbf{9 6}$.

Duluth gabbro: Grout, 380, 382.

east central: Harder and Johnston, 403 .

Nevada, Reese River basin: Waring, 993.

Yerington district: Knopf, 528.

New York, Adirondack Mountains : Alling, 16; Miller, 677 ; syenite-granite series: Miller, $67 \mathrm{~s}$.

Gouverneur quadrangle: Cushing, 2.14.

Lake Bonaparte quadrangle: Buddington and Smyth, 118.
Igneous and volcanic rocks-Continued.

North Carolina: Lugeon and Sigg, 596.

Ontario, Dryden gold area, district of Kenora: Thomson, 943.

Kowkash area : Hopkins, .455.

Matachewan area: Burrows, 132.

Slate Islands: Parsons, $\mathbf{7 4 5}$.

Oregon, Cascades: Smith, 8S4.

Pennsylvania, eastern: Touas, 485.

Quebec, Gaspe County, Lemieux : Mail. hiot, 615 .

Rhode Issland: Hawkins, 412.

Texas, trans-Pecos front range: Baker and Bowman, 32.

Vermont, Cuttingsille: Eggleston, 277.

Washington, Colville Indian Reservition: Pardee, 741.

Wisconsin, southeastern: Alden, S.

Wyoming, western: Schultz, 8.83.

Igneous banding, origin: Grout, 380 .

Illinois.

General.

Soils, Champaign County: IIopkins et al., 450.

McLean County: Hopkins et al., 449.

Economic.

Fluorite, optical, southern Jllinois: Pogue, 758

Oil and gas fields: Wheeler, $101 \mathrm{~s}$.

Physiographic.

Abandoned beaches, south end of Lake Michigan : Wright, 1080.

Camp Grant . quadrangle: Anon., 1095.

stratigraphic.

Camp Grant environment: Salisburv and Barrows, 813 .

Chester series: Ulrich, 962 .

Marl deposits, central Illinois: Baker, 33.

Starved Rock State Park: Cady, 1.43.

Till, character in southern Illinois: Shaw, 853 .

Paleontology.

Post-glacial Mollusca, central Illinois: Baker, 33.

Mineralogy.

Fluorite, optical, southern Illinois: Pogue, 758.

Indicia of dip in rocks: Logan, 583 .

Indiana.

Dynamic and structural.

Mount Carmel fault: Logan, 582.

Physiographic.

Indianapolis: Dryer, 267 .

Paleontology.

Mysticocrinus, St. Paul : Springer, 897.

Insecta.

General : Cockerell, 190.

Beetles, Tertiary, Colorado: Cockerell, 189. 
Insecta-Continued.

Cockroaches, Pennsylvanian; Pennsylvania : Cockerell, 189.

Tsetse flies: Cockerell, 189.

Intrusions. See also Dikes; Igneous and volcanic rocks; Laccoliths ; Magmas.

Duluth lopolith: Grout, 378.

Invertebrata (general). See also Anthozoa; Brachiopoda; Bryozoa ; Crustacea ; Echinodermata ; Foraminifera ; Insecta ; Mollusca ; Problematica ; Spongida ; Vermes.

Amsden formation, Wind River Mountains, Wyoming: Branson and Gregor, 103.

Conemaugh and Pottsville faunas, West Virginia : Price, 267.

Richmond fauna, Little Bay de Noquette, Michigan: Foerste, 315.

Iowa.

Dynamic and structural.

Mud-crack limestone, Devonian: Fenton, 303.

Physiographic.

Camp Dodge area: I.ees and Alden, 557.

Stratigraphic.

Cedar Valley beds, Floyd County: Fenton, 303.

Pleistocene, Crawford and Carroll counties: Kay, 497.

Iron.

General : Burchard, 122.

Lateritic ore deposits : Miller, 672.

Titanic ores, microstructure: Warien, 994.

Alabama, Birmingham district: Singewald, 868.

Cuba, Weld, 1011.

Minnesota, Cuyuna district: Harder and Johnston, 403; Newton, 710.

magnetite deposits of Duluth gabbro, magnetic surveys of : Broderick, 106.

Mesabi range: Wolff, 1074.

Ontario, Kowkash area: Hopkins, 455. nortbwestern : Parsons, 746.

Rainy River, district: Robinson, 797.

Porto Rico, Mayaguez, limonite: Fettke and Hubbard, 310.

Quebec, Belcher Islands: Moore, 692, 693.

Santo Domingo: Brinsmade, 105.

Tsobases of postglacial uplift: Fairchild, $296,297$.

Jamaica.

Stratigraphic.

Tertiary, correlation: Vaughan, 979 . Jerome district, Arizona: Finlay, 313.

Jurassic.

Stratigraphy.

Alaska, Chitina Valley : Moffit, 683.

Gravina and Revillagigedo islands: Chapin, 167.

Nelchina-Susitna region: Chapin, 168.

British Columbia, Crowsnest and Flathead areas: Rose, 806.

Vancouver area : Burwash, 135.

Cuba : DeGolyer, 241; Hayes, Vaughan, and Spencer, 421.

Idaho, southeastern: Schultz, 833.

Montana, Birch Creek-Sun River region: Stebinger, 905 .

Garnet Range: Pardee, 738.

northeastern: Collier, 200.

southwestern : Condit, 202.

Morrison formation, age: Schuchert, 830.

South Dakota, Black Hills region: Darton, 228.

Utah, Green River desert : Emery, 288.

Morgan County, Lost Creek field: Clark, 175.

Wyoming, Salt Creek oil field: Wegemann, 1010.

western : Condit, 202 ; Schultz, 833.

Kanawha black flint: Price, 768 .

Kansas.

Économic.

Natural gas: Moore and Haynes, 697.

Petroleum: Moore and Haynes, 697; Whitaker et al., 1030.

Dynamic and structural.

General ; Darton, 227.

Central Kansas: Perrine, 751.

Wood replaced by calcite, Russell : Greenland, 364.

Physiographic.

Camp Funston region: Moore, 695.

Kaw Lake area: Todd, 948.

Stratigraphic.

General: Darton, 227; Moore ind Haynes, 697.

Borings, central Kansas: Perrine, 751.

Central Kansas: Perrine, 751.

Comanchean, central Kansas: Twenhofel, 956 .

Crystalline rocks, geologic history : Moore, 696.

Fort Scott-Boone interval: Berger, 64.

Kaw Lake area: Todd, 948.

Pleistocene history: Todd, 947.

Paleontology.

Wood replaced by calcite, Russell : Greenland, 364.

Petrology.

Crystalline rocks: Moore and Haynes, 697.

Kentucky.

Economic.

Coal, Letcher County: Crider, 211.

Shawneetown quadrangle: Lee, 552. Oll fields: Thayer, 938. 
Kentucky-Continued.

Economic-Continued.

Petroleum : I.emberton, $\mathbf{7 4 8 .}$

Shawneetown quadrangle: Lee, 552.

Physiographic.

Camp Taylor region: Butts, 141.

Stratioraphic.

Chester series, western Kentucky: U1rich, 962.

Geologic map : Sellier, 844.

Georgetown quadrangle, map : Miller, 671.

Mississippian formations, western Kentucky : Butts, 140.

Shawneetown quadrangle: Lee, 552.

Paleontology.

Chester series, western Kentucky: UIrich, 962.

Mississippian formations, western Kentucky: Butts, 140 .

Filldeer Mountains, North Dakota: Quirke, 772 .

Kowkash gold area, Ontario: Hopkins, 445.

Iabrador.

General : Coleman, 196.

Iaccolithic intrusion, mechanics of : Keyes, 507.

Lacustral record of post climates: Keyes, 510.

Lafayette formation: Shaw, 850 .

Lakes.

Great Basin lakes, origin : Keyes, 509, 510.

Lakes, extinct.

Lake Bonneville, age: Keyes, 510 .

Lake Lohontain, age, mammalian evidence: Merriam, 660.

Lakes, glacial. See Glacial lakes.

Lamellibranchiata. See Pelecypoda.

Landslide.

Colorado, San Juan Mountalns: Atwood, 25.

Langley field, Hampton quadrangle, Virginia : Stephenson, 907.

Iava.

Oregon, Cascades: Smith, 884.

Lead.

Alaska : Martin, 623.

California, Inyo Range: Knopf, 527.

Central States: Dunlop and Butler, 274.

Colorado: Henderson, 428.

Eastern States: Hill, 436.

Idaho: Gerry, 331.

Missouri-Kansas-Oklahoma zinc district: Wright, 1078 .

Nevada: Heikes, 427.

Arabia district : Knopf, 529.

Clark County, Yellow Pine district: Hale, 389.

Quebec, Gaspe County, Lemfeux : Mallhiot, 615

Utah : Helkes, 426.

Washington : Gerry, 331.
Lapadiclae, derivation: Clarke, 187.

Lignite. See also Coal.

Siskatchewan, southern: MacLean, 609.

Lime.

General: Loughlin, 586.

Limetone.

Oklahoma : Cullen, 213.

Ontario: Frechette, 320 .

Lithogenesis: Grabau, 354.

Lithology. See Petrology.

Lithothamnieae, Panama Canal Zone: Howe, 462

Loess.

General : Tomlinson, 950

Eolian loess: Todd, 949.

Louisiana : Emerson, 286.

Long Lake gold mine, Sudbury district, Ontario: Baker, 34.

Lopolith : Grout, 378.

Louisiana.

Economic.

Oil pools, Gulf Coast country: Matteson, 634 .

Petroleum: Deussen, 251.

Northern Louisiana: Bates, 55.

Red River field: Bates, 54.

Salt domes, intrusive origin: Rogers, 803.

structure : Lucas, 594

Dynamic and structural.

Red River, Crichton oll field: Butes, 54.

\section{Stratigraphic.}

Borings : Deussen, 251.

De Soto-Red River oil field: Bates, 54.

Loess deposits: Emerson, 285, 286.

Red River, Crichton oil fleld: Bates, 54.

Tertiary, correlation: Vaughan, 979.

Lower Silurian. See Ordovician.

Magmas. See also Intrusions.

Alkaline rocks, genesis: Daly, 225.

Convection, two-phase: Grout, 381 .

New York, Adirondack Mountains, syenite-granite series: Miller, 678.

Two-phase convection : Grout, 381.

Vermont, Cuttingsville: Eggleston, 277.

Magmatic differentiation.

Juluth rocks: Grout, 382.

legmatites of Duluth gabbro: Grout, 377.

Magnesite.

General: Hamilton, 392 ; Yale and Gale, 1084, 1085.

British Columbia, Pacific Great Eastern Railway : Camsell, 150.

Canada: Malcolm, 616.

Washington : Stone, 918, 919.

Valley: Jenkins, 474.

Magnetic surveys of magnetite deposits of Duluth gabbro: Broderick, 106. 
Maine.

Physiographic.

Fleistocene shore lines: Katz, 492, 493.

I'etrology.

Litchfieldite: Daly, 226.

Mineralogy.

Mt. Mica and Mt. Apatite: Manchester and Bather, 617.

\section{Mammalia.}

Artiodactyla, Uinta Basin, Utah : Peterson, 753.

Bats, Porto Rico: Anthony, 20.

Camelidae: Matthew, 646.

Canis, subdivision : Merriam, 658 .

Colorado, San Juan Basin: Granger, 357.

Cuba : Allen, 13.

Edentata: Stock, 916.

Equidae, revision: Osborn, $\mathbf{7 2 3}$.

Felis, Rancho La Brea, California: Merriam, 659 .

Idaho formation: Merriam, 657.

Mammoth, New York: Clarke, 181.

Mastodon, New York: Clarke, 181.

South Carolina : Loomis, 584.

South Dakota : Osborn, 726.

Megalocnus: Matthew, 643 .

Moropus: Matthew, 642 ; Osborn, 725.

New Mexico, San Juan Basin : Granger, 387.

Northarctus: Granger and Gregory, 359.

Nothodectes, dentition: Matthew, 641.

Perissodactyla, absence of pollex : Matthew, 640 .

Pinnepedia: Kellogg, 500.

Pleistocene fauna, Hawver Cave, California : Stock, 917.

Proboscidea, generic nomenclature: Matthew, 645 .

phylogeny: Osborn, 726.

Rhinoceros, Pliocene: Matthew, 647 .

Rodentia, Porto Rico: Anthony, 19.

Tapir, Pleistocene, Florida : Sellards, 840.

Tiffany beds fauna: Matthew and Granger, 649.

Tillodont skull, Huerfano Basin, Colorado: Granger, 358.

Zanycteris (Paleocene bat), Colorado: Matthew, 639.

Man, fossil.

Antiquity in America: Holmes, 446.

Florida, Vero: Hay, 418, 419, 420 ; Nelson, 707; Wieland, 1046.

Massachusetts, Boston: Shimer, 862.

Marble.

British Columbia: Parks, 743.

Marginal sedimentation: Cotton, 209.

Marine clastics, diagnostic. characteristics : Kindle, 518.

Marine limestone strąa, superficial dip: Mather, 626.

Marl.

General: Loughlin, 586.
Manganese.

General: Hewett, 431; Palmer, 733; Watson, 1003.

Lateritic ore deposits: Miller, 672.

Arizona : Allen and Butler, 15.

British Columbia, Slocan district: Bancroft, 38.

California: Bradley et al., 100; Louderback, 585 .

Colorado River desert region: Jones, 486.

Costa Rica : Spilsbury, 896.

Georgia: Anon., 1096.

Montana, Butte: Pardee, 739.

Madison County: Pardee, 740.

Nevada, Clark County : Hale, 390.

Oregon: Anon., 1097.

Lake Creek: Pardee and Parks, 742.

Tennessee, Bradley County: Purdue, 771.

eastern: Stose and Schrader, 923.

Texas, Val Verde Co.: Roberts and Nash, 794.

Vermont, South Wallingford: Jones, 488.

Virginia, Frederick County: Haney, 397.

Shenandoah Valley: Hewett et al.. 433.

Washington, northern: Jenkins, 473.

Manitoba.

Economic.

Clay, Swan River valley: Johnston, 484.

Copper, Schist Lake district: Bruce, 113.

Gold, southeastern Manitoba: Marshall, 621 .

Star Lake area: Marshall, 622.

Wekusko Lake, origin: Alcock, 7.

Herb Lake district: Bruce, 112.

Hudson Bay Railway: Johnston, 483.

Molybdenum, Falcon Lake area : Bruce, 114.

Northern Manitoba: Bruce, 112; Tyrrell, 957; Wallace and DeLury, 990.

Sand, Swan River valley: Johnston, 484.

Schist Lake district, northern Manitoba: Bruce, 112, 113.

Southeastern Manitoba: Marshall, 621. Star Lake area : Marshall, 622.

Tungsten, Falcon Lake: DuLury, 24. .

Wekusko Lake area, northern Manitoba: Alcock, 6.

Stratigraphic.

Amisk-Athapapuskow Lake district: Bruce, 111.

Falcon Lake area : Bruce, 114.

Hudson Bay Railway: Johnston, 483.

Northern Manitoba: Bruce, 112; Wallace and DeLury, 990 .

Schist Lake district, northern Manitoba: Bruce, 112, 113.

Silurian, Fudson Bay region: Savage, 816. 
Manitoba-Continued.

Stratigraphic-Continued.

Southeastern Manitoba : Marshall, 621.

Wekusko Lake area, northern Manitoba: Alcock, 6.

Paleontology.

Silurian, Hudson Bay region: Savage, 816.

Map making. See Cartography.

Maps. Sce Cartography ; Geologic maps.

Maryland.

Economic.

Anne Arundel County: Little, 577.

Physiographic.

General: Clark, 178.

Anne Arundel County : Little, 577.

Stratigraphic.

General : Clark et al., 179.

Anne Arundel County: Little, 577.

Ordovician, Piedmont : Bassler, 47, 48.

Underground vater.

General : Clark et al., 179.

Anne Arundel County: Little, 577.

Massachusetts.

Physiographic.

Camp Devens area: Atwood, 26.

Stratigraphic.

Boston, postglacial history: Shimer, 862.

Matachewan sold area, Ontario: Burrows, 132.

Mechanics of vein formation: Taber, 927.

Metamorphism.

British Columbia, Vancouver area : Bur'wash, 135.

Nevadil, Yerington district: Knopf, 528.

Rhode Island: Hawkins, 412.

volume changes in metamorphism: Liudgren, 576.

Meetings. Sce Associations.

Meganos group, Eocene, California: Clark, 171.

Mercury. See Quicksilver.

Mesozoic (undifferentiated).

Alaska, Lake Clark - central Kuskokwim region: Smith, 878.

Franciscan sandstone: Davis, 230.

Nevada, Reese River basin: Waring, 993.

Oregon, Cascades : Smith, 884.

\section{Meteorites.}

General.

Fluorine and tin in meteorites: Merrill, 666.

Heating meteoric stones, effects : Merrill, 666.

Iron phosphide: Wherry, 1029

Maskelynite: Merrill, 666.

Cedar, Fayette County, Texas: Merrill, 665 .

Fustis, Florida: Merrill, 662.

Planview, Texils: Merrill, 664.
Mexico.

Generat.

Bibliography : Aguilar, 5.

Economic.

-Talisco : Villafaña, 982 .

Oil indications, Pacific coast: Palacios, 730 .

Petroleum: Bustamante, 136; De Golyer, 245.

Soda deposits, Lake Texcoco: Flores, 314.

Sonora, ore deposits: Tovote, 952.

Sulphides, relation to water level in Mexico: Lucke, 595.

Dynamic and structural.

Desert phenomena, San Luis Potosi: Wittich, 1070 .

Earthquake, Sonora: MacDonald, 608. Oil field temperatures: DeGolyer, 244.

Seismology in Mexico: Mũ̃oz Lumbier, 704.

Physiographic.

Tampico embayment area: Dumble, 271.

Stratigraphic.

Cienega, Mexico: Galvez, 326.

Jalisco: Villafaña, 982.

Lower California, Magdalena Bay: Galvez, 324

O1l possibilities, southern Tamaulipas: Ord6ñez; 721 .

Tamaulipas, southern: Ordóñez, 721.

Tampico embayment area: Dumble, 271.

Tequesquipan, Mexico: Galvez, 325.

Tertiary, correlation: Vaughan, 979.

Palcontology.

Pleistocene Mollusca, Magdalena Bay, Lower California: Dall, 221.

\section{Mineralogy.}

General: Wittich, 1069.

Mazapilite and arseniosiderite, iden. tity : Larsen, 548.

\section{Underground water.}

Cienega, Mexico : Galvez, 326.

Lower California, Magdalena Bay: Galvez, 324.

Tequesquipan, Mexico: Galvez, 325. Mica.

General: Schaller, 824.

Michigan.

Physiograplic.

Camp Custer region : Leverett, 567.

Glacial lakes, superior basin: Leverett, 566 .

Northern Peninsula, surface geology: Leverett, 565.

Southern P'eninsula, surface geology: Leverett, $\mathbf{5 6 5 .}$

\section{Stratigraphic.}

Northern Peninsula, surface geology: Leverett, 565 .

Silurian, early, Northern Peninsula: Savage and Crooks, s1s. 
Michigan-Continued.

Stratigraphic-Continued.

Southern Peninsula, surface geology: Leverett, 565 .

\section{Paleontology.}

Devonian, Detroit River series : Stauffer, 903 .

Richmond fauna, Little Bay de Noquette : Foerste, 315.

Military geology and topography : Gregory, et $a l ., 368$.

Mineral reserves: Smith, $876 a$.

Mineral resources. See Economic (general).

\section{Mineral water.}

General: Ellis, 280.

Canada : Elworthy, 282.

Mineralogy (general). see also Meteorites;

Technique. For regional, see names of States. For particular minerals, see list, p. 128.

Beryl, prismatic cleavage: Lane, 546.

Colerainite, origin : Poitevin, 760.

Copiapite in coal : McCaughey, 605.

Crystallized mineral specimens, developing : Grenzig, 370 .

Diasporite, field identiflcation : Wherry, 1025.

Etching figures of the dibexagonal alternating type: Honess, 448.

Famous mineral localities, Keokuk geode region: Wherry, 1021.

Gypsum and glauberlte, thermo-optical observations: Kraus and Peck, 536.

Handbook : Butler, 139.

History, 1818-1918: Ford, 317.

Indexing a mineral collection: Fairbanks, 295

Iridescent quartz, New York City : Scott, 838 .

Iron, cause of blue colors in minerals : Wherry, 1027.

Lazulite: Merrill, 667.

Mazapilite and arseniosiderite, identity : Larsen, 548.

Saline dome minerals, Texas-Louisiana Coastal Plain: Hawkins, 414.

Vivianite, color change: Watson, 1004.

\section{Minnesota.}

Economic.

Iron, Cuyuna district: Harder and Johnston, 403 ; Newton, 710.

Mesabi range: Wolff, 1074.

Magnetite deposits of Duluth gabbro, magnetic survey of: Broderick, 106.

Stone: Bowles, 96.

\section{Stratigraphic.}

General : Bowles, 96

Cuyuna district: Harder and Johnston, 403.

Duluth lopolith : Grout, 378.

East central Minnesota: Harder and Johnston, 403.
Minnesota-Continued.

Stratigraphic-Continued.

I'egmatites of Duluth gabbro: Grout, 377.

Petrology.

General: Bowles, 96.

Duluth gabbro: Grout, 380,382 .

East central Minnesota: Harder and Johnston, 403.

Fegmatites of Duluth gabbro; Grout, 377.

Mineralogy.

General: Bowles, 96 .

Miocene. See Tertiary.

Miscellaneous. See also Addresses.

Philosophy of geology and the order of the state: Clarke, 182.

\section{Mississippi.}

Physiographic.

Northern and central Mississippi : Shaw, 850 .

Pliocene history, northern and central Mississippi : Shaw, 850 .

\section{Stratigraphic.}

Correlation of Jackson and Vicksburg deposits: Cooke, 205.

Pliocene history, northern and central Mississippi: Shaw, 850.

Tertiary, correlation: Vaughan, 979

Mississippian. See Carboniferous.

Mississippian chert of St. Louis area : Barton, 44.

Mississippian formations, western Kentucky : Butts, 140.

\section{Missouri.}

General.

Greene County: Shepard, 860.

Ecónomic.

General : Branson, 102

Barite: Tarr, 932.

Greene County : Shepard, 860.

Jackson County: McCourt et al., 606.

Mineral resources: Buehler, 121.

Oil and gas possibilities, Belton area : Wilson, 1057 .

Washington County, barite district: Tarr, 932.

Dynamic and structural.

Chert, origin: Dean, 240.

Physiographic.

General: Branson, 102.

Jackson County: McCourt et al., 606.

Stratigraphic.

General : Branson, 102.

Barite districts : Tarr, 932.

Belton area: Wilson, 1057.

Greene County: Shepard, 860.

Grassy Creek shale : Greger, 365.

Jackson County : McCourt, et al., 606.

Kinderhook, lower: Branson, 101.

Washington County, barite district: Tarr, 932

Puleontology.

General : Branson, 102.

Grassy Creek sbale: Greger, 365 . 
Missouri-Continued.

Petrology.

Chert, origin: Dean, 240.

Mineralogy.

Joplin district: Hawkins and Wherry, 414.

Mollusca, See also Cephalopoda; GastroGeneral. poda ; I'elecypoda.

Nomenclature rectifications: Henderson, 429.

Arisaig series, Nova Scotia : McLearn, 611.

California, San Lorenzo series : Clark, 172.

Florida, Volusia County: Mansfield, 619.

Illinois, postglacial: Baker, 33.

Mexico, Jower California, Pleistocene: Dall, 221.

Pleurodonte debooyi, st. Croix, West Indies: Bartsch, 45.

Washington, Oligocene: Van Winkle, 974.

Molluscoidea. Sce Brachiopoda; Bryozoa.

Molybdenum.

General : Wolf, 1072.

Occurrence: Ball, 36.

California: Boalich and Castello, 83.

Canada: Malcolm, 616.

Colorado, Climax: Brown and Hayward, 109 ; Haley, 391.

Summit County : Holland, 445.

Manitoba, Falcon Lake area: Bruce, 114.

Ontario: Parsons, 744.

Dryden gold area, district of Kenora : Thomson, 943.

Quebec, Pontiac County: Thomson, 944.

Quyon district: Wilson, 1059.

Timiskaming County: Wilson, 1058.

Monks Mound: Crook, 212.

\section{Montana.}

Eeonomic.

Garnet Range: Pardee, 738.

Iccland spar: Parsons, 747.

Lake Basin field, oil and gats possibflities; Hancock, 395 .

Manganese, Butte: Pardee, 739.

Madison County; Pardee, $\mathbf{7 4 0}$.

Oil and gas possibilities; Birch CreekSun River area, northwestern Montana : Stebinger, 905.

Oil shales, Beaverhead County : Bowen, 87.

Dynamic and structurat.

Birch Creek-Sun River area, northwestern Montana: Stebinger, 905.

Lake Basin field: Hancock, 395.

Musselshell Valley, anticlines: Bowen, 92.
Montana-Continued.

Physiographic.

Garnet Range: Pardee, 738.

Northeastern Montana: Collier and Thom, 201.

Stratigraphic.

Birch Creek-Sun River area, northwestern Montana: Stebinger, 905 .

Flaxville gravel: Collier and Thom, 201.

Garnet Range: Pardee, 738.

Lake Basin field: Hancock, 395.

Musselshell Valley: Bowen, 92.

Northeastern Montana: Collier, 200.

Southwestern Montana: Condit, 202.

Paleontology.

Oligocene plants: Jenningss, 476 .

Mineralogy.

Jceland spar: Parsons, 747.

Mazulite : Merrill, 667.

Mullanite: Shannon, 846.

Moraines.

Cololado, Estes Park: Wooster, 1077.

San Juan Mountains: Atwood, 25.

Ohio, Holmesville: Cole, 192.

Wisconsin, southeastern: Alden, 8.

Moropus: Matthew, 642.

Morrison formation: Mook, 691; age: Schuchert, 830 .

Mounds.

Origin : Crook, 212.

Mount Rainier National Park: Matthes, 636.

Natural gas.

General: Northrop, 711: Wyer, 1082.

Gas sands: Knapp, 525.

Gasoline vapor content change : Sieplein, 866.

Migration: Ziegler, 1.090 .

Movement through rocks: Washburne, 996 ; Ziegler, 1090.

Alberta : Dowling, 265.

Viking field: Slipper, 871.

Illinois : Wheeler, 1018.

Louisiana, northern: Bates, 55.

Oklahoma, Osage Reservation: Bowen, 90, 91; Clark, 174; Emery, 287; Heald, 423; Heald and Mather, 425 ; Hopkins, 454 ; Lloyd and Mather, 579; Ross, 807; White, 1031.

Pawhuska quadrangle: Heald, 424.

West Virginia: White, 1032.

Wyoming, Cretaccous fields: Trum. bull, 955.

Nebraska.

Economic.

Clay : Barbour, 39.

Potash : Condra, 203.

Dynamic and structural.

General: Darton, 227.

Stratigraphic.

General: Darton, 227.

Nelchiua-Susitna region, Alaska : Chapin, 168 . 
Nevada.

Economic.

Alunite, Sulphur, Humboldt Counts : Clark, 176.

Antimonial silver-lead veins, Arabia district: Knopf, 529.

Gold, silver, copper, lead; and zinc in 1916; Heikes, 427.

Manganese, Clark County : Hale, 890 .

Silver, Wonder : Youn:?, 1087.

Tonopah ores, genesis: Bastin and Laney, 51.

Yellow Pine district, Claris County : Hale, 389.

Yerington district : Knopf, 523.

Strationaphic.

Arabia district: Knopf, 529.

Reese River basin: Waring, 993.

Yellow Pine district, ilaris County : Hale, 389.

Yerington district: Knopf, 528.

Petrology.

Yerington district: Knopf, 528 .

Underground water.

Reese River basin: Wariag, 993.

New Hampshire,

Physiographic.

Pleistocene shore line: Iiat\%, 492, 493.

Mineralory.

Beryl, Acworth: Holden, 144.

New Jersey.

General.

State geologist, report: Kümmcl, 537. Pliysiographic.

Northern New Jersey : Loheck, j80.

Mineralogy.

Gageite, Franklin Furnace: Levison. 569.

Thaumasite: Wherry, 1020.

\section{Now Mexico.}

Economic.

Fluorine in sericitization, Tyrone. district: Paige and Steiger, 729.

Ore deposits of the Southwest: Tovote, 952.

Sierra del Oro, northern New Mexico : Keyes, 512.

Sulphur, Jemez Canyon: Mansfield, $618 a$.

Dynamic and structural.

Sierra del. Oro, northern New Merico: Keyes, 512.

Physiographic.

Southwestern New Mexico: Schwennesen, 836.

stratigraphic.

Raton Mesa region: Lee, 554.

Paleontology.

Nothodectes, San Juan Basin: Mat. thew, 641 .

San Juan Basin, Mammalia: Granger, 357.

Vermejo and Raton floras: Knowlton, 535.
New Mexico-Continued.

Underground water.

Animas, Playas, Hachita, and San Luis basins: Schwennesen, 836.

New York.

General.

Geological survey, report: Clarke, 181.

Economic.

Graphite, Adirondack Mountains: Alling, 16.

Mineral rescurces, 1916: Newland, 709.

Zinc ores, Edwards district, St. Lawrence County: Smyth, 887 .

Dynamic and structural.

Boulders borne by icebergs,. Ithaci region: Von Engeln, 9S3.

Plastic deformation of Grenville limestone, Port Henry region : Newland, 708 .

Strand markings, Portage group: Clarke, 184.

Unstable rocks under Hudson River: Berkey, 65 .

Vein formation, central New York: Taber, 926.

Physiographic.

Camp Mills region, Liong Island: A!den, 10.

Camp Upton region: Alden, 9.

Cliff Haven: Hudson, 464.

Drainage modification, Tompkins County: Hausman, 409.

Finger Lake basins, origin: Yon Engeln, 984.

Rochester district: Giles, 327.

Southeastern New York: Lobeck, 5S0.

Stratigraphic.

Adirondack anorthosite: Miller, 67i.

Adirondack graphite deposits: Alling, 16.

Cayuga. and Onondaga counties: Taber, 926.

Cliff Haven, Hudson, 464.

Clinton: Chadwick, 158.

Eskers, Rochester district: Giles, 337.

Geological survey, report: Clarke, 181.

Glaciation, Catskill Mountains: Rich, 784.

Gouverneur quadrangle: Cushing, 214.

Lake Bonaparte quadrangle : Buddington and Smyth, 118.

Lake Placid quadrangle: Miller, 675.

Schroon Lake quadrangle: Miller, 675.

Sherburne bar, significance in Devonic stratigraphy : Grabau, 348.

Silurian: Chadwick, $\mathbf{1 5 9}$.

Syenite-granite series, Adirondack Mountains: Miller, 678.

Tully limestone and Genesee shale, - relationship: Grabau, 855 .

\section{Paleontology.}

Clinton: Chadwick, 15.9.

Devonian glass sponges: Clarke, 183.

Embryocrinus problematicus: Hudson, 465. 
New York-Continued.

Petrology.

Adirondack anorthosite: Miller, 676, 677.

Syenite-granite series, Adirondack Mountains : Miller, 678 .

Minesalogy.

Quartz, iridescent, New York City:

Nickel. Scott, 838 .

California:- Boalich and Castello, 84. Lateritic ore deposits: Miller, 672.

Ontario, Sudbury: Roberts and Longyear, 791, 792, 793 .

Timiskaming district: Baker, $3 \overline{5}$.

Oregon, southeastern: Williams, 1048.

Tennessee, cave deposits : Glenn, 340.

Nivation, northern Greenland, Ekblaw, 279.

Nomenclature. See also under Stratigraphic.

Surficial formations: Shaw, 850 .

North Carolina.

Stratigraphic.

Tertiary, correlation: Vaughan, 979.

l'aleontology.

Foraminifera, Coastal PJain: Cushman, 215.

Petrology.

Eruptive rocks: Lugeon and Sigg, 596.

Mineralogy.

Famous mineral localities, gem regions : Trudell, 954.

North Dakota.

General.

Road materials: Fard, 399.

Economic.

Lignite, Willinms Co.: Collier, 199.

Nesson anticline, Williams County: Collier, 199.

Dynamic and structurat.

Valley filling: Collier, 198.

Physiographic.

Eskers and kames, Barnes County: Hard, 400 .

Killdeer Mountains: Quirke, 772.

Lake Agassiz: Leverett, $\mathbf{5 6 4}$.

Stratigraphic.

Filldeer Nountains: Quirke, 772.

Nesson anticline, Williams County: Collier, 199.

\section{Northwest Territory.}

Dynamic and struetural.

Sedimentation, Mackenzle River basin : Kindle, 515.

\section{Sitratigraphic.}

Great Slave Lake region: Cameron, 146.

Notharctus: Granger and Gregory, 359.

Nothodectes, dentition: Matthew, 641.

\section{Nova Scotia.}

Eoonomic.

Oil shales, Pictou, Cape Breton: Spence, 892.
Nova Scotia-Continued.

Stratigraphic.

Arisaig series: McLearn, 611.

Ohio.

Economic.

Berea sand, lithology: Panyity, 736. 4

Physiographic.

Camp Sherman region: Campbell, 147. 4

Stratigraphic.

Deep wells: White, 1036.

Holmesville terrace and moraine: Cole, $\mathscr{X}$ 192.

Paleontology.

Agelacrinites and Streptaster, Rich-y mond group: Williams, 1053 .

Agelacrinites rectiradiatus, Richmond group: Shideler, S61.

\section{Mineralogy.}

Copiapite in coal: AcCaughey, 605. Oil. S'ce r'etroleum.

Oil shales.

General: Alderson, 11; Gilbert and Pogue, 355.

Colorado, northwestern: Adkinson, 4 ; Alderson, 11 ; Chase, 169; Hoskin, 459; Zlegler, $10 \$ 9$.

Montana, Beaverhead County: Bowen, 87.

Nova Scotia, Pictou: Spence, 892.

Utah: Adkinson, 4; Ziegler, 1089.

Uinta Basin: Winchester, 1065.

\section{Oklahoma}

Économic.

Age of oil in the southern fields:

Matteson, 635 ; Pratt, 765.

Lime resources: Cullen, 213.

Mid-Continent field : Bloesch, 80.

Mineral resources: Snider, 888.

Natural gas, Osage Reservation: Bowen, 90, 91; Clark, 174.; Emery, 287; Heald, 423 ; Heald and Mather, 425 ; Hopkins, 454 ; Lloyd and Mather, 579; Ross, 807; White, 1031.

Oil sands, correlation: Aurin, 28.

Osage Reservation: Bowen, 89, 90, 91 ; Clark, 174 ; Emery, 287; Heald, 423; Feald and Mather, 425: Hopkins, 454; Lloyd and Mather, 579 ; Ross, 807.

Petroleum : Burton, 134.

Osage Reservation: Bowen, 89, 90, 91; Clark, 174; Emery, 287; He a ld, 423; H e ald and Mather, 425; Hopkins, 454 ; Lloyd and Mather, 579; Ross, 807; White, 1031; Winchester et al., 1067.

Tripoli deposits: Perry, 752.

Dynamic and structural.

Osage Reservation, structure: Emery, 287.

Travertine deposits, Arbuckle Mountains, Oklahoma: Emis, 289, 290 . 
Oklahoma-Continued.

Physiographic.

General: Snider, 888.

stratigraphic.

General : Snider, 888.

Borings: Aurin, 28.

Fort Scott-Boone interval: Berger, 64 .

Oil sands, correlation: Aurin, 28.

Osage County: Greene, 363 .

Osage Reservation: Bowen, 89, 90, 91; Clark, 174 ; Emery, 287 ; Heald, 423; Heald and Mather, 425; Hopkins, 454 ; Lloyd and Mather, 579; Ross, 807 ; Winchester et al., 1067.

Pawhuska quadrangle: Heald, 424.

Red beds: Aurin, 27; Ohern, 718.

Southern Oklahoma: Stephenson, 909.

Tertiary: Berry, 69.

Travertine deposits : Emig, 289.

Paleontology.

Ontario.

Tertiary plants: Berry, 69.

Economic.

Copper, northwestern Ontario: Parsons, 746 .

Sudbury: Roberts and Longyear, 792.

Gold, Benoit township : Burrows, 130.

Dryden area, district of Kenora : Thomson, 943.

Gauthier township: Burrows, 131.

Kowkash area: Hopkins, 455.

Long Lake mine: Baker, 34.

Matachewan area: Burrows, 132.

Rickard township: Hopkins, 456.

Iron, northwestern Ontario: Parsons, 746.

Rainy River district: Robinson, 797.

Kowkash gold area: Hopkins, 455 .

Lake Abitibi area: Hopkins, 458.

Limestones: Frechette, 320.

Longuelac to Jellicoe: Burrows, 129.

Matachewan gold area: Burrows, 132.

Mineral industry, 1917: Gibson, 333.

Molybdenite: Parsons, 744.

Northwestern Ontario: Parsons, 746.

Nickel, Alexo mine, Timiskaming district: Baker, $\mathbf{3 5}$.

Sudbury: Roberts and Longyear, 792.

Ogahalla to Collins, Northern Transcontinental Railway: Hopkins, 457.

Oil fields, development: Williams, 1051.

Oil prospecting, southwestern. Ontario: Williams, 1052.

Report of Bureau of Mines, 1917 : Gibson, 332.

Silver, Cobalt: Reid, 781.

Slate Islands, Lake Superior: Parsons, $\mathbf{7 4 5}$.

Sudbury district: Baker, 34 .
Ontario-Continued.

Economic-Continued.

Sudbury deposits, origin: Goodchild, 342.

Sudbury nickel-copper deposits: Roberts and Longyear, 791, 793.

Timiskaming district: Baker, 35.

Physiographic.

Ottawa beach of Champlain sea : Kindle, 517.

\section{Stratigraphic.}

Gauthier township: Burrows, 131.

Kowkash gold area: Hopkins, 455.

Lake Abitibi area: Hopkins, 458.

Longuelac to Jellicoe: Burrows, 129.

Matachewan gold area: Burrows, 132.

Northwestern Ontario: Parsons, 746.

Ogahalla to Collins, Northern Transcontinental Railway: Hopkins, 457.

Slate Islands, Lake Superior: Parsons, 745 .

Sudbury district: Baker, 34 .

Timiskaming district: Baker, 35 .

Toronto region : Coleman, 195.

Paleontology.

Devonian, Onondaga limestone: Stauffer, 903.

Mollusca, Mackay Lake, Ottawa: Whittaker, 1043.

Mineralogy.

Euxenite: Miller and Knight, 674.

Oolite.

Inorganic origin : Bucher, 116.

Origin : Bucher, 117.

in shale: Tarr, 933.

Siliceous oolites in shale: Tarr, 930.

Types of Paleozoic: Van Tuyl and Croolss, 973.

\section{Ordovician.}

stratigraphy.

General : Clarke, 181.

Alaska, Cosna-Nowitna region: Eakin, 275.

southeastern: Kirk, 520.

California, Inyo Range: Kirk, 519.

Georgia, Appalachian Valley: Shearer, 858.

Idaho, southeastern: Schultz, 833.

Illinois, Starved Rock State Park: Cady, 143.

Martinsburg shale: Hintze, 440.

Maryland, Piedmont Plateau : Bassler, $47,48$.

Missouri : Branson, 102.

barite districts: Tarr, 932.

Greene County: Shepard, 860.

New York, Cliff Haven: Hudson, 464.

Ontario, Toronto region: Coleman, 195.

Pennsylvania, Blair and Funtingdon counties section: Butts, 142.

Quebec, Timiskaming County: Wilson, 1058 . 
Ordozieian-Continued.

Stratigraphy-Continued.

Saskatchewan, Amisk Lake district: Bruce, 111.

South Dakota, Black Hills region : Darton, 228.

Texas, trans-Fecos front range : Baker and Bowman, 32.

Vermont, central: Richardson, 788 ,

Virginia, Buchanan County: Hinds, 439.

Piedmont Plateau : Bassler, 47, 48.

Wisconsin, southeastern: Alden, 8.

Wyoming, western: Schultz, 833; Blackwelder, 76.

\section{Paleontology.}

Richmond fauna, Little Bay de Noquette; Michigan: Foerste, 315.

Ore deposits, origin. For ore deposits in general see Economic (general).

General: Boyd, 97; Emmons, 292; Hastings, 408.

Fluorine in sericitization: Paige and Steiger, 729 .

Halogen salts of silver: Burgess, 125.

Lateritic ore deposits: Miller, 672.

Mechanics of vein formation: Taber, 927.

Pressure in formation of ore deposits: Taber, 925.

Sphalerite, relation to other sulphides in ores: Graton, 360 ; Watson, 1002.

Vein formation: Taber, 927.

Barite, Missouri : Tarr, 932.

British Columbia, Telkwa district: Dolmage, 260.

Carnotite deposits, origin: Notestein, 714.

Copper, California, Engels: Graton and McLaughlin, 362 .

Nevada, Yerington: Knopf, 528.

Oriente, Cuba: Emerson, 284.

Sudbury, Ontario: Roberts and Longyear, 793 .

Gold, deposition in nature: Lenher, 562.

in Canadian pre-Cambrian deposits : Wallace, 989.

Manitoba, Wekusko Lake: Alcock, 7.

Saskatchewan, Amisk Lake district: Bruce, 111.

Iron, Belcher Islands, Hudson Bay : Moore, 693.

limonite, Mayaguez, Porto Rico: Fettke and Hubbard, 310.

titanic ores: Warren; 994.

Lead and zinc, Missouri: Tarr, 929.

Magnesite, Valley, Washington : Jenkins, 474.

Manganese, Virginia : Hewett et al., 433.
Oro deposits-Continued.

Molybdenite, Pontiac County, Quebec: Thomson, 944.

Montana, Garnet Range: Pardee, 738. Ontario: Sudbury deposits: Goodchild, 342.

Sudbury nickel-copper ores: Roberts and Longyear, 791.'

Nevada, Clark County, Yellow Pine district: Hale, 389.

Tonopah: Bastin and Laney, 51.

Nickel, Ontario, Timiskaming district: Baker, 35.

Sudbury, Ontario: Roberts and Longyear, 793.

Quicksilver, Arizona, Phoenix Mountains: Schrader, 826 .

California: Bradley, 98.

Silver, Cobalt, Ontario: Reid, 781.

halogen salts, occurrence: Lindgren, 572 .

Nevada, Wonder: Young, 1087.

Silver halides, occurrence: Knopf, 534.

Sulphides, relation to water level in Mexico: Lucke, 595.

Uranium-vanadium ores: Notestein, 714.

Utah, Tooele County: Kemp and Billingsley, 503.

Zinc: Boyd, 97.

California, Inyo Range: Knopf, 527.

Colorado, Leadville: Loughlin, 590.

Joplin-Miami district: Buehler, 120.

New York, Edwards district: Smyth, 887.

Ore deposits of the Southwest: Tovote, 952.

\section{Oregon.}

General.

Cascades: Smith, 885.

Economic.

Cascades: Smith, 884.

Manganese: Anon., 1097.

Lake Creek: Pardee and Parks, 742.

Nitrate deposits, southeastern Oregon: Williams, 1048.

Physiographic.

Block faulting, Klamath lakes region : Johnson, 480.

Columbia River gorge: Chaney, t.66.

Wallowa Mountains: Smith, 886.

Stratigraphic.

General: Smith, 883.

Cascades: Smith, 884

Columbia River gorge: Chaney, 166.

Franciscan sandstone: Davis, 230.

Oligocene: Clark and Arnold, 173.

Paleontology.

General: Smith, 883.

Eagle Creek flora, Columbia River gorge: Chaney, 166.

Mineralogy.

Opal, fibrous form : Merrill, 663.

Ore shoots. Sée Economic geology; Ore deposits, origin.

$122541^{\circ}-19-8$ 
Organic deposits of the sea: Vaughan, 977 . Orogenj.

Geueral: Barrell, 42; Thayer, 937.

California, Inyo Range: Knopf, 527.

Laccolithic intrusion, mechanics of: Keyes, 507.

Laccolitḷic mountains, origrin: Keyes, 511.

Oseillation. See Changes of level.

Paleobotany.

Clathropteris: Berry, 72.

Cycadeoid wood structure: Wieland, 1044.

Cycadeoidea; fioral structures: Wieland, 1047.

Dakota sandstone, leaves: Gress, 371.

Dicotyls, origin : Wieland, 1045.

Eagle Creek flora, Columbia River gorge: Chaney, 166.

Neocalamites, restoration : Berry, 71 .

Oklahoma, Plantae: Berry, 69.

Oligocene plants, Montana: Jennings, 476.

Panama Canal zone: Berry, 70.

Stonewort, Jura-Cretaceous: Hannibal, 398.

Vermejo and Raton floras: Knowlton, 535.

Willows and poplars, history: Berry, 68.

Wood replaced by calcite: Greenland, 364.

\section{Paleoclimatology.}

General: Huntiagton, 466; Lull, 599 ; Schuchert, 827, 831.

Alaska, sedimentary record of climate: Blackwelder, 77.

Amelioration of climate : Manson, 620 ; Mather, 625 .

Devonian : Clarke, 184.

Lacustral record of past climates: Keyes, 510.

Paleo-ecology : Clements, 188.

Paleogeography. See also Geologic history ; Paleoclimatology; Pa l e o g e ographic maps.

General: Lull, 599 ; Schuchert, 827.

California, Tertiary: Clark and Arnold, 173.

Chester series: Ulrich, 962.

Missouri: Branson, 102.

Ontario dome, influence on Tertiary drainage : Grabau, 351 .

Rocky Mountains, southern, Mesozoic: Lee, 556.

Sherburne bar, significance in Devonic stratigraphy: Grabau, 348.

Silurian, Arisaig series: McLearn, 611. Canada, Savage, 816.

Tertiary, Eocene: Harris, 406.

Washington, Oligocene: Weaver, 1009.

\section{Paleogeographic maps}

Chester sea : Vlrich, 962.

Tully time: Grabau, 355.

Paleometeorology. See Paleoclimatology.
Paleontology (general). See also the classes of animals and Paleobotany. For stratigraphic see the different systems. For regiona! see names of States. See also Erolution.

General : Mather, 628; Schuchert, 831; Washburne and Washburne, 995 . Arrested erolution: Ruedemaun, 80 s.

Isolation a development factor: Griabatt, 349 .

Missouri, index fossils : Branson, 102.

Organic evolution: Lull, 597.

Origin of life: Woodruff, 1076.

Paleoecology : Clements, 188.

Pathological conditions in fossils : Moodie, 686.

Ring structures in silica: Stansfield, 901.

Vertebrae, evolution: Williston, 1055.

Paleontology of arrested evolution: Ruedemann, 808.

Paleozoic (undifferentiated).

Alaska, Chitina Valley: Moffit, 683.

Lake Clarke-central Kuskokwim region: Smith, 878.

Arctic regions, Ellesmere and Grinnell lands: Holtedahl, 487.

Cuba: Hayes, Vaughan, and Spencer, 421.

Nevada, Reese River basin: Waring, 993.

Palladium.

General.

Occurrence: Kunz, $\mathbf{5 4 1 .}$

Nevada, Clark County, Yellow Pine district : Hale, 389.

Panama Canal Zone.

Stratigraphic.

Tertiary, correlation: Vaughan, 979.

Paleontology.

Bryozoa, Emperador limestone: Canu and Bassler, 153.

Cirripedia : Pilsbry, 756.

Decapod Crustacea: Rathbun, 774 .

Echini : Jackson, 468.

Foraminifera: Cushman, 216, 217.

Lithothamnieae: Howe, 462.

Plantae: Berry, 70.

Paragenesis of minerals.

British Columbia, Telkwa district: Dolmage, 260.

Colorado, Leadville: Loughlin, 590.

Nevada, Yerington district : Knopf, $\mathbf{5 2 8}$

Peat.

General: Osbon, 722.

Peneplains.

Appalachian peneplains, age: Shaw, 856.

Idaho, northern : Rich, 786.

Idaho peneplain, age: Lindgren, 575 ; Livingston, 578; . Rich, 786, $\because$ rii 787 . 
Pennsylvania.

Ëconomic.

Glass sands : Fettke, 309.

Pyrite in coal : Leighton, 558.

Uranium-vanadium ores, origin: Notestein, 714.

Dynamic and structural.

Temperature in deep wells: Van Orstrand, 970 .

\section{Stratigraphic.}

Blair and Funtingdon counties section: Butts, 142.

Boring, McDonald : White, 1033.

Boyertown Hills, eastern Pennsylvania: Jonas, 485 .

Deep wells : White, 1036.

Martinsburg shale: Hintze, 440.

Pre-Cambrian and Triassic diabase, eastern Pennsylvania: .Jonas, 485.

Pre-Cambrian sedimentary rocks in Highlands of eastern Pennsylvania: Wherry, 1028.

\section{Paleontology.}

Chemung sponges, Erie: Clarke, 183.

Cockroaches, Pennsylvanian: Cockerell, 189.

Rutiodon, York: Sinclair, 867.

Petrology.

Boyertown Hills, eastern Pennsylvania: Jonas, 485.

Pre-Cambrian sedimentary rocks in Highlands of eastern Pennsylvania: Wherry, 1028.

\section{Mineratogy.}

Limonite pseudomorphous after pyrite, Lancaster County : Willig, 1054.

Sylmar : Wherry, 1024.

Wavellite, Northampton County: Wherry, 1020.

Pennsylvanian. See Carboniferous.

Pentremites. See Blastoidea.

Periodic diastrophism, production of : Chamberlin, 164.

Permian. See Carboniferous.

\section{Petroleum.}

General: Burton, 133; Gilbert and Pogue, 335 ; Northrop, 712 ; Ziegler, 1091.

Accumulation : Lewis, 570.

in salt domes: Jonas, 491.

Bibliography, 1915 : Burroughs, 128.

Dip of marine limestone strata : Mather, 627.

Geology : Allen, 14; O'Harra, 717 ; Ziegler, 1088

Migration : Ziegler, 1090.

through sedimentary rocks: McCoy, 607.

Movement through rocks: Washburne, 996 ; Ziegler, 1090.

Occurrence and quality, relation to uplift and folding: Shaw, 854 .

Oil-bearing and oil-producing formạtions: Grabau; 347.

oil-bearing Paleozoic formations: Grabau, 353.
Petroleum-Continued.

General: Oil field temperatures: DeGolyer, 244.

Oil fields, origin: van der Gracht, 966.

Oil prospects under western Lake Erie: Nattress, 706.

Origin: Coste, 208; Steidtmann, 906.

Petrology of reservoir rocks : Lewis, 570 ; Rogers, 802.

Pools, origin : Steidtmann, 906.

Popular oil geology : Ziegler, $108 s$.

Porosity of oil sands: Shaw, 852 .

Porosity of rocks, relation to accumulation: Jones, 489.

Salt domes, origin : Dumble, 272.

Salt water, relation to accumulation: Johnson, 481.

Source and origin of salt dome oll: Lucas, 594.

Water surfaces in oll fields: Daly, 223.

Alberta, Peace River region : McLearn. 610.

Sheep River area: Slipper, 870 .

Berea sand, Ohio, lithology: Panyity, 736.

Cuba : DeGolyer, 241.

Gulf region: Lucas, 594.

Illinois: Wheeler, 1018.

Kansas: Whitaker et al., 1030.

Kentucky: Pemberton, 748; Thayer, 938.

Louisiana: Deussen, 251.

Gulf Coast country : Matteson, 634.

northern: Bates, 55.

Red River field: Bates, 54.

Mexico: Bustamante, 136; DeGolyer, 245.

Pacific coast: Palacios, 730.

Tamaulipas: Ordoñez, 721.

Mid-Continent field : Bloesch; 80 .

Oklahoma : Bloesch, 80; Burton, 134.

age of oil in southern fields, Matteson, 635 ; Pratt, 765.

Osage Reservation: Bowen, 89, 90, 91; Clark, 174; Emery, 287 ; Heald, 423; Heald and Mather, 425 ; Hopkins, 454 ; Lloyd and Mather, 579 ; Ross, 807 ; White, 1031 ; Winchester et al., 1067.

Pawhuska quadrangle : Heald, 424.

Ontario, southwestern: Williams, 1052.

Tennessee, Glenmary field: Glenn, 341.

Texas: Deussen, 251.

Gulf coast country: Matteson, 634 .

north central: Hager, 388 ; Kempher, 504.

United States: Hager, 385.

West Virginia : White, 1032.

Wyoming, Cretaceous fields: Trumbull, 955.

Salt Creek oil field: Wegemann, 1010. 
Petrology (general). See also Igneous andvolcanic rocks; 'Technique. For regional sce numes of states. For rocks described, see list, $p$. 128.

Alkaline rocks, genesis: Daly, 225.

Chert, origin : Davis, 232.

Continental clastics, characteristics: Blackwelder, 74 .

Dolomite, formation of: Skeats, 869 . Glass-making processes: Bowen, 93.

History : Pirsson, 757.

Lithogenesis: Grabau, 354.

Jopolith : Grout, 378.

Marine clastics, diagnostic characteristics: Kindle, $\mathbf{5 1 8 .}$

Multiple rock diagrams: Grout, 383.

Sedimentary rocks, interpietation : Grabau, 354.

Serpentine, origin: Benson, 63.

Synthesis of rocks, experimental studies: Sosman, 890 .

Volume changes in metamorphism : Lindgren, 576 .

Philosophy of geology and the order of the state: Clarke, 182.

Phosphate.

General : Stone, 920

Idaho, southeastern: Schultz, 883.

Origin of western phosphates: Mansfield, 618 .

Utah, Uinta Mountains: Schultz, 834. Wyoming, western: Schulti, 833 .

Phosphorus.

General : Stone, 920

Physiographic (general). For regional, see under various states. Sice also Drainage changes.

Appalachian peneplains, age: Shaw, 856.

Bibliography: Lobeck, 580.

Continental shelf, origin: Cotton, 209.

Desert deltas, rate of growth : Keyes, 506.

Desert depressions, origin: Hobbs, 442 .

Geologic dates, use of: Rich, 785 .

Idaho peneplain, age: $\mathrm{Rich}, 7 \$ 7$.

Lacustral record of past climates : Keyes, 510.

Thysiographic divisions of North America : Thayer, 937.

I'rogress of interpretation of land; forms: Gregory, 367.

Rocky Mountains, southern, Mesozoic: Lee, 556 .

Submarine banks: Davis, 234 .

United States, geographic provinces: Jefferson, 472.

Pisces.

Alberta, Cretaceous selachian: Jambe, 544.

Hydrocyon, fossil allies: Eastman, 276.

Plants, fossil. See Paleobotany.

Platinum.

General : Hill, 435.

Occurrence: Kunz, 541 .
, Platinum-Continued.

Canada: Malcolm, 616.

Nevada, Clark County, Yellow Pine district: Hale, 389 .

Wyoming:.Taft, 928 .

Pleistocene. See Glacial geology: Quaternary.

Pliocene. See Tertiary.

Polyzoa. Sce Bryozoa.

Popular oil geology : Ziegler, 1088.

Porosity of oil sands: Shaw, 852.

Portland cement. See Cement.

Porto Rico.

Economic.

Limonite deposits, Mayaguez Mesa: Fettke and Hubbard, 310.

Dynamic and sẗructural.

Changes of level, recent: Mitchell, 681.

Stratigraphic.

Coamo-Guayama region: Hodge, 443.

San Juan district: Semmes, 845 .

Paleontology.

Bats: Anthony, 20.

Faunas: Reeds, 776.

Rodentia: Anthony, 19.

Potash.

General: Coolbaugh, 207.

Culifornia: Boalich and Castello, S4.

Canada: Malcolm, 616.

Georgia, Cartersville slates: Shearer, 858.

Nebraska : Condra, 203.

Saskatchewan : Dowling, 263.

\section{Potholes.}

General : Elston, 281

\section{Pre-Cambrian.}

General.

Correlation and nomenclature in the St. Lawrence Basin: Wilson, 1060.

Stratigraphy.

Arizona, Jerome district: Finlay, 313.

British Columbia, Crowsnest and Flathead areas: Rose, 806.

California, Inyo Range: Kirk, 519.

Manitoba, Schist Lake district: Bruce, 113.

southeastern : Marshall, 621.

Wekusko Lake area: Alcock, 6.

Minnesota, east central: Harder anil Johnston, 403

Montana, northeastern: Collier, 200.

New York, Adirondack Mountains : Alling, 16.

Gouverneur quadrangle: Cushing,

$$
\text { - } 214 .
$$

Lake Bonaparte quadrangle: Buddington and Smyth, 118.

Northwest Territory, Great Slave Lake region: Cameron, 146.

Ontario, Dryden gold area, district of Kenora : Thomson, 943.

Gauthier township: Burrows, 131.

Kowkash area: Hopkins, 455. 
Pre-Cambrian-Continued.

Stratigraphy-Continued.

Ontario, Long Lake district: Baker, 34 ; Burrows, 129.

Matachewan area: Burrows, 132.

Slate Islards: Parsons, 745.

Sudbury: Roberts and Longyear, 791.

Timiskaming district: Baker, 35.

Toronto region: Coleman, 195.

Pennsylvania, eastern: Jonas, 485. sedimentary rocks: Wherry, 1028.

Quebec, Belcher. Islands, Hudson Bay : Moore, 693.

Pontiac County : Thomson, 944.

Timiskaming County: Wilson, 1058.

Saskatchewan, Amisk Lake district: Bruce, 111.

Wisconsin, southeastern: Alden, 8.

Wyoming, Medicine Bow Range: Blackweider and Crooks; 78.

\section{J'aleontology.}

Atikokania lawsoni: Abbott, 1; Walcott. 987.

\section{Precious stones.}

General: Schaller, 822, 823.

Irimates. See Mammalia.

\section{Pseudomorphs.}

Limonite after pyrite, Iancaster County, Pennsylvania: Willig, 1054.

\section{Pyrite.}

General: Smith, 879,880

Colorado, Leadville: Lee, $\mathbf{5 5 1 .}$

Fieorgia: Shearer and Hull, 859.

I'ennsylvania coals : Leighton, 558.

South Carolina, Kershaw: Watkins, 1001.

Tennessee, Ducktown: Taylor, 935.

\section{Pyrrhotite.}

Tennessee, Ducktown : Taylor, 935.

Virginia, southwestern: van Mater, 969.

Quaternary. See also Glacial geology.

Genesal: Hay, 417.

Stratigraphy.

Alaska, Chitina Valley : Moffit, 683 .

California, Inyo Range: Knopf, 527.

Idaho, southeastern: Schultz, 833.

Illinois, Starvèd Rock State Park: Cady, 143.

Kentucky, Shawneetown quadrangle: Lee, $\mathbf{5 5 2}$.

Lake Lahontain, age, mammalian evidence : Merriam, 660.

Massachusetts, Boston : Shimer, $\mathbf{8 6 2 .}$

Montana, northeastern: Collier, 200.

Texas, Val Verde County: Roberts and Nash, 794

Washington, Quincy Valley: Schwennesen and Melnzer, 837.

Wyoming, Park County: Moody and Taliaferro, 688 .

westein :"Schultz, 833.
Quaternary-Continued.

Paleontology.

California, Pleistocene, Hawver Cave: Stock, 917.

Illinois, postglacial Mollusca: Baker, 33.

Massachusetts, Boston: Shimer, 862.

Mexico, Lower California, I'leistocene Mollusca: Dall, 221.

Nevada, Reese River basin: Waring, 993.

Ontario, Mackay Lake, Mollusca : Whittaker, 1043.

Tapir, Pleistocene, Florida: Sellards, 840.

Quebec.

Economic.

General: Denis, 250.

Belcher Islands, Hudson Bay: Moore, $692,693$.

Iron, Belcher Islands, Hudson Bay : Moore, 692, 693.

Lead, Lemieux, Gaspe County : Mailholt, 615 .

Lemieux, Gaspe County: Mallhoit, 615.

Mining operations, 1917 : Denis, 250.

Molybdenite, l'ontiac County: Thomson, 944.

Quyon district: Wilson, 1059.

Tiniskaming County: Wilson, 1058.

Zinc, Lemieux, Gaspe County: Mallhoit, 615 .

Dynamic and structural.

Vein systems in l'ercé rock: Clarke, 185.

Physiographic.

Timiskaming County: Wilson, 1058.

stratigraphic.

Algal limestone, Belcher . Islands: Moore, 694.

Belcher Islands, Fudson Bay: Moore, 693.

Black Lake area, Megantic County: T'oitevin and Graham, 761 .

I.emleux, Gaspe County : Mailhoit, 615.

Molybdenite area, Pontiac County: Thomson, 944.

Timiskaming County: Wilson; 1058.

Mineralogy.

Black Lake area, Megantic County: Joitevin and Graham, 761.

Colerainite, origin: Poitevin, 760.

\section{Quicksilver.}

Alaska, Lake Clark-central Kuskokwim region: Smith, 878 .

Arizona, Phoenix Mountains: Schrader, 826.

California : Bradley, 98.

Idaho, central: Bell, 62 .

Racewinite, Bingham: Winchell, 1061.

Radiolarian cherts of Franciscan group : Davis, 232. 
Radium.

Colorado, southwestern: Kithil and Davis, 522.

Distribution of deposits : Moore, $69 \mathrm{~S}$.

Utah, southeastern: Kithil and Davis, 522.

\section{Rare earths.}

General: Schaller, 821.

Raton Mesa region, Colorado-New Mexico: Lee, 554.

Red Beds, origin : Kright, 526 .

\section{Telief maps.}

Idaho: Livingston, $\mathbf{5} 7 \mathrm{~S}$.

Lake Superior district: Harder and Johnston, 403.

Mexico: Bustamante, 136.

\section{Reptilia.}

Alligator, Tertiary : Matthew, 644.

Apatosaurus: Mfook, 689 .

Dinosaurs, sauropol, habitat: Mook, 691.

Diplodocus, fore and hind limbs: Mook, 690.

Edaphosaurus, Arch County, Texas: Case, 157.

Monoclonius, Red Deer River: Brown, 107.

Mosasaurs, diseases: Moodie, 6 S5.

Permian : Williston, 1056

Rutiodon, Triassic, Pennsylvania : Sinclair, $\$ 67$.

Sauropoda, specific characters: Mook, 689.

Stegosaurus: Gilmore, 38s: Lambe, 545 .

Trachodon: Lambe, 543.

Restorations.

General: Washburne and Washburne, 995.

Clathropteris: Berry, $\mathbf{7 2}$.

Edaphosaurus, Archer Connty, Texas: Case, 157 .

Megalocnus: Matthew, 643.

Monoclonius : Brown, 107.

Moropus : Matthew, 642.

Neocalamites: Berry, 71 .

Stegosaurus: Gilmore, 338.

\section{Rhode Island.}

Stratigraplbic.

Igneous rocks: Hawkins, 412.

Petrology.

Igneous rocks: Hawkins, 412.

Mineralogy.

Fibrous quartz: Hawkins, 411.

Quartz crystals, Centerdale : Hawkins, 410.

Rhythms: Barrell, 40.

Ripple mark: Kindle, 518.

Road materials.

Nonbituminous: Reinecke, 782.

Rock-boring animals, geologic significance: Barrows, 43.

Rock slides. See Landslides.
Rocks, structural features. See also Ripple marks.

Anomalous dips: Shaw, 857.

Dolomitization, depth: Van Turl, 972. Igreous rocks: Grout, 380 .

Fnclicia of elip in rocks: Logan, 583 .

Marine elastics, diagnostic characteristics: Kindle, 518.

Mud-crack limestone, Deronian: Fenton, 303 .

Oolites and spherulites: Bucher, 117.

Oolites in shale, origin : Tarr, 933.

Plastic deformation of Grenville limestone, Fort Heniy region: Newland, $70 \mathrm{~S}$.

Porosity of oil sands: Shaw, $\mathbf{8 5 2}$.

Rbythmic banding of manganese dioxide in rhrolite tuff: Tarr, 934.

Rock-boring animals, geologic significance: Barrows, 43.

Sorting of sectimentary rocks: Shaw, $\$ 49$.

Strand markings, Portage group : Clarke, 184.

Stylolitic structure in Tennessee marble, origin : Gordon, 345.

Vein systems in Feicé rock: Clarke, 185.

Rocks described. See list, p. 128.

Rocky Mountains, physlographic methods of correlation: Lee, $\mathbf{5 5 5}$.

St. Croix.

Puleontology

Pleurodonte debooyi: Bartsch, 45.

Salines.

California, Death Valley: Young, 1086.

Salt.

General: Stone, 922.

Migration: Kindle, 516.

Separation from saline water ant mud : Kindle, $\mathbf{5 1 6 .}$

Salt deposits.

Origin: Graban, 350.

Virginia, southwestern, origin : Thomas, 940 .

Salt domes.

General : Irawkins, 413.

Accumulation of oil in salt domes: Jones, 491.

Cap rock, origin: DeGolyer, 240.

Origin: Dumble, 272 ; Matteson, 634 ; Thomas, 941.

intrusive origin: Rogers, $\mathrm{SO3}$.

Volcanic origin theory: DeGolyer, 243.

\section{Salvador.}

Dynamic and structural.

Quetzaltepeque, eruption: Lacroix, 542.

San Salvador, eruption, June, 1917 :

Friedlaender, 323 ; Powers, 763.

San Lorenzo series, California: Clark, 172. 
Sand:

Bibliography: Hopkins, 451.

Manitoba, Swan River valley: Johnston, 484.

Moulding sands: Cole, 193.

\section{Sandstone.}

British Coluinbia: Parks, 743.

Canada : Cole, 194.

Saltsburg sandstone: Brown, 110.

Santo Domingo.

Economic.

Iron: Brinsmade, 105.

Stratioraphic.

Yaqui Valley: Maury, 650.

Paleontology.

General: Maury, 650.

\section{Saskatchewan.}

Economic.

Amisk-Athapapuskow Lake district: Bruce, 111.

Clay, southern Saskatchewan: Davis, 233.

Gold, Amisk Lake district: Bruce, 111.

Lignite, southern Saskatchewan: MacLean, 609 .

Potash : Dowling, 263.

Southeastern Saskatchewan: Stansfield, 900 .

Stratigraphic.

Amisk-Athapapuskow Lake district: Bruce, 111.

Southeastern Saskatchewan: Stansfield, 900 .

Southern Saskatchewan: MacLean, 609.

Petrology.

Amisk-Athapapuskow Lake district: Bruce, 111.

Sedimentiry rocks, interpretation : Grabau, 354.

Sedimentation. See also Conglomerates; Erosion.

Chemical deposits of the sen : Vaughan, 977.

Climatic types of sediments: Blackwelder, 74 .

Continental clastics, characteristics: Blackwelder, 74 .

Continental shelf, origin: Cotton, 209.

Graptolite shales, depth at which formed: Grabau and O'Connell, 356.

Mackenzie River basin: Kindle, 515.

Marginal sedimentation : Cotton, 209.

Organic deposits of the sea: Vaughan, 977.

Shoul-water bottom samples: Vaughan et $a l, 981$.

Sorting of sediment: Shaw, 849 .

Seismology. See also Earthquakes.

Analysis of earthyuake waves: Klotz, 523.

Eartluquake waves, transmission: Klotz, 524.

Mexico: Muñoz Lumbier, 704.
Seismology-Continued.

Seismic and magnetic disturbances, relation: Hazard, 422.

Starting point of earthquake vibrations: Reid, 780.

Teleseismic registration: Jaggar and Romberg, 470.

Seismology in Mexico: Muñoz Lumbier, 704. Selenium.

General: Umpleby, 964, 965.

\section{Serpentine.}

Origin : Benson, 63.

Shale.

Canada: Keele, 498.

Shale oil.

General: Mitchell, 682.

Shoal-water bottom samples: Vaughan et $a l ., 9 S 1$.

Shore lines. See also Beaches; Terraces.

Criteria for determination: Fairchila, 298.

Maine, Pleistocene shore lines: Katz, 493.

Michigan : Leverett, $\mathbf{5 6 5}$.

New Hampshire, Pleistocene shore lines: Katz, 493.

Silica.

General: Katz, 495:

Silurian.

Geveral: Grabau, 352.

Correlation, America and Europe: Grabau, 352.

Stratigraphy.

Arisaig series, Nova Scotia: McLearn, 611.

Canada, Hudson Bay reglon: Savage, 816.

Clinton, Anticosti section: Ulrich, 963.

New York: Chadwick, 158.

Michigan, northern Peninsula: Savage and Crooks, 818.

Missouri : Branson, 102.

Montana, Garnet Range: Pardee, 738.

New York : Chadwick,. 159.

central: Taber, 926 .

Northwest Territory, Great Slave Lake reglon: Cameron, 146.

Pennsylvania, Blair and Huntingdon counties section: Butts, 142 .

Quebec, Timiskaming County: Wilson, 1058.

Wisconsin, soutbeastern: Alden, 8.

Wyoming, western: Schultz, 833.

\section{Paleontology.}

Arisaig scries, Nova Scotia: McLearn, 611.

Canada, Fudson Bay region: Savage, 816.

Clinton, New York: Chadwick, 158.

Indiana, Mysticocrinus: Springer, 897.

Michigan, liorthern I'eninsula: Savage and Crooks, 818 . 
Eilver.

General: McCaskey and Dunlop, 603. Halogen salts, occurrence: Lindgren, 572 .

Alaska : Martin, 623.

British Columbia, Telkwa district: Dolmagre, 260.

California, Inyo Range: Knopf, 527.

Central States: Dunlop and Butler, 274.

Colorado: Henderson, 428.

Eastern States: Hill, 436.

Idaho: Gerry, 331.

Nevada: Heikes, 427.

Arabia district: Knopf, 529.

Clark County, Yellow Pine district: Fale, 389.

Tonopah : Bastin and Laney, 51.

Wonder : Young, 10 s7.

Ontario, Cobalt: Reid, 781.

Quebec, Timiskaming County: Wilson, 1058.

Utah : Heikes, 426.

Washington: Gerry, 331.

Slate.

General : Loughlin, 58s.

Georgia, Appalachian Valley: Shearer, . 858 .

Slides. See Landslides.

Soapstone.

General : Diller, 258.

Soda.

Mexico, Lake Texcoco: Flores, 314.

Soils.

Wisconsin, Columbia Co.: Whitson, et al., 1041.

Jefferson County: Whitson et al., 1040.

north cen,tral: Whitson et al., 1042.

northeastern: Whitson et al., 1039.

Solifuction, northern Greenland: Ekblaw, 279.

South Carolina.

Economic.

Pyrite, Kershaw: Watkins, 1001.

Stratigraphic.

Tertiary, correlation: Vaughan, 979.

Paleontology.

Foraminifera, Coastal Plain: Cushman, 215.

Mastodon: Loomis, 584.

\section{South Dakota.}

Economic.

Tungsten, Black Hills: Runner and Hartmann, 810 .

Dynamic and structural.

General: Darton, 227.

Stratigraphic.

General : Darton, 227.

Black Fills region : Darton, 228.

Paleontology.

Alligator, Tertiary: Matthew, 644.

Mastodon: Osborn, 726.
South Dakota-Continued.

Mineralogy.

Black Hills : Wherry, 1023.

Underground water.

Black Hills region: Darton, 228.

Spherulites, origin: Bucher, 117.

Spongida.

Devonian glass sponges: Claike, 183. Starved Rock State Park, Illinois: Cady, 143.

Stegosaurus : Lambe, 545.

Stone.

General : Loughlin, 5s7.

Minnesota : Bowles, 96.

Strata, depth and thickness, graphic method for determining: Palmer, 732 .

Stratigraphic (general). For regional, see names of states. Sec also the different systems.

General: Schuchert, 831.

Coal seams, spore-exines of : Thiessen, 939.

Oil-bearing and oil-producing formations: Grabau, 347.

Rock-boring animals, geologic significance : Barrows, 43.

Correlation.

Alasska, southeastern, Mesozoic: Chapin, 167.

Antilles, Tertiary: Tones, 490.

Chester series: Ulrich, 962.

Colorado, Raton Mesa region: Lee, 554.

Cretaceous, Texas and 'Oklahoma: Stephenson, 909.

Eocene, Atlantic and Pacific: Dickerson, 254.

Gulf Coast formations: Matteson, 634.

Jackson and Vicksburg deposits, Alabama and Mississippi: Cooke, 205.

Mississipplan formations, western Kentucky : Butts, 140.

New Mexico, Raton Mesa region: Lee, 554.

Oil-bearing and oil-producing formations: Grabau, 347.

Pacific coast: Smith, 884 .

Pennsylvanian : Savage, 817.

Permo-Carboniferous: Case, 156.

Pre-Cambrian: Wilson, 1060.

Rocky II o u n a ins, physiographic methods of correlation: Lee, 555.

San Lorenzo series, California : Clark, 172.

Sediments, character, use of: Blaciswelder, 75.

Tertiary, Antilles: Tones, 490.

Tertiary, southeastern U. S., and Antillean region: Vaughan, 979.

Texas, Marathon Basin: Baker and

". Bowman, 32. 
Stratigraphic (general)-Continued.

I'ubles of formations.

Alabama: Hager, 387.

Alaska, southeastern, Mesozoic: Ch:ıin, 167.

British Columbia, Vancouver area : Burwash, 125.

Chester series: Ulrich, 962.

Colorado: Ziegler, 1091.

Raton Mesa region: Lee, 554.

Cuba: Hayes, Vaughan, and Spencer, 421.

Georgia, Appalachian Valley : Shearer, 858.

Idaho, southeastern : Schultz, 893 .

Kansas: Moore and Haynes, 697.

Missouri, Greene County: Shepard, 860.

Montaua, Birch Creek-Sun - River region: Stebinger, 905 .

northeastern : Collier, 200.

New Mexico, Raton Mesa region: Lee, 554.

Ontario, Toronto region : Coleman, 195.

South Dakota, Black Fills region: Darton, 228.

Tennessee, eastern: Stose and Schrader, $92 \%$.

western: Dunbar, 273.

Tertiary, correlation: Vaughan, 979.

'Jexas, Marathon Basin: Baker and Bowman, 32.

Washington, Oligocene: Van Winkle, 974.

Wyoming, Park County: Moody aud Talia fer ro, 688 .

Salt Creek oil field: Wegemann, 1010.

western: Schultz, 833.

\section{Strontium.}

General: Boalich and Castello, 84; Hill, 437 ; Meade, 651.

California, Barstow : Knopf, 530.

Structural materials. See Building stone, - Clay, etc.

Structure of Great Plains: Darton, 227.

Study and teaching. Sce Educational.

Stylolitic structure in marble, origin: Gordon, $344,345$.

Submarine banks: Davis, 234.

Sulsidence. Sce Changes of level.

Subterranean water. See Underground water.

Sulphur.

Gencral: Smith, s79, 850 .

New Mexico, Jemez Canyon: Mansfield, $61 \mathrm{Sa}$.

lexas, trans-Pecos region: Thomas, 942.

\section{Surveys.}

Florida : Sellards, 839

Government geologic surveys: Smith, 875.

New Jersey, State geologist's report : Kiimmel, 587.

Texas, report, 1915 : Stiles, 914 .
Surveys-Continued.

United States: Smith, 874.

Washington, report, 1015-17: Wash. (т. S., 1000.

Wisconsin, report, 1916-18: Wis. G. S.; 1068.

Tables. See Stratigraphic, Tables of formations.

Talc.

General: Diller,.258.

Technique.

Crystallized mineral specimens; developing, Grenzig, 370.

Dip, projection of, graphic method: Palmer, 732.

Field-work methods: Roark, 790 .

Measuring temperature in deep wells: Van Orstiand, 970.

Multiple rock diagrams: Grout, 383 .

Preparation of a report: Vitn Ingen, 968.

Strata, depth and thickness, graphic method for determining: I'almer, 732 .

Tests for metals in minerals: Finsett, 301.

Telkwa distrlet, British Columbia : Dolmage, 260.

Tellurium.

General: Umplehy, 964, 965.

Tennessee.

Generil

Cave deposits, composition : Glenn, 340 , Economic.

Barite, Sweetwater district: Gordon, 343.

Manganese, Bradley . County: Pudue, 771.

east Tennessee: Stose and Schrader, 923.

Petroleum, Glenmary field : Glenn, 341. Pyrite and pyrrhotite, Ducktown : 'Taylor, 935.

Dynamic and structural.

Stylolitic structure in Tennessec marble, origin : Gordon, $.344,345$.

Stratigraphic.

Chester series: Ulrich. 962.

Devonian, western T'ennessee: Junbar, 273 .

Glenmary oil field: Gienn, 341 .

Sweetwater district, east Tennessee: Gordon, 343.

ralcontology.

Devonian, western Tennessee: Dunlar, 273.

\section{Terraces.}

General: Fairchild, 298.

Mississippi, northern and central, Pliocene : Shaw, 850 .

Ohio, Holmesville: Cole, 102.

Wisconsin, Mississippi River: Martin, 624. 
Tertiary.

General.

Correlation: Osborn, 723 .

Stratigraphy.

Alabama: Hager, 387.

Jackson and Vicksburg deposits: Cooke, 205.

- Alaska, Nelchina-Susitna region : Chapin, 168.

Arctic regions, Ellesmere and Grinnell lands: Holtedahl, 447.

Barbados: Craig, 210.

British Columbia, Crowsnest and Flathead areas: Rose, 806.

Vancouver area: Burwash, 135.

California, Carrizo Creek beds: Dickerson, 253.

Inyo Range: Knopf, 527.

Salinats Valley : English, 294.

San Lorenzo series: Clark, 172.

Colorado : Ziegler, 1091.

Raton Mesa region: Lee, 554 .

Cuba : DeGolyer, 241 ; Hayes, Vaughan and Spencer, 421.

Eocene, correlation: Dickerson, 254.

Eocene deposits, geographic conditions: Harris, 406.

Florida, westeri: Sellards and Gunter, 842, 843 .

Georgia, Claiborne and Jackson deposits: Cooke and Shearer, 206.

Gulf Coast formations: Matteson, 634 .

Haiti: Jones, 490."

Idaho, southeastern: Schultz, S33.

Kansas: Meore and Haynes, 697.

central: Perrine, 751.

Iientucky, Shawneetown quadrangle: Lee, $5 \overline{0} 2$.

Lafayette formation: Shaw, 850.

Lafarette gravel: Shaw, 855.

Maryland, Anne Arundel County : Little, 577.

Meganos group, Eocene, California: Clark, 171.

Mexico, Tampico embayment area : Dumble, 271.

Mississippi, Jackson and Vicksburg deposits: Cooke, 205.

Montana, Birch Creek-Sun River region : Stebinger, 905 .

Garnet Range: Pardee, 738.

Lake Basin field: Hancock, 395.

Musselshell Valley : Bowen, 92.

northeastern: Collier, 200; Collier and Thom, 201.

Nerada, Reese River basin: Waring, 993.

Yerington district: Knopf, 528.

New Mexico, Raton Mesa region : Lee, 554.

North Dakota, Killdeer Monntains: Quirke; 772.

Nesson anticline, Williams County: Collier, 199.

Oklahoma: Berry, 69.

Oligocene, Pacific coast: Clark and Arnold, 173.
Tertiary-Continued:

stratigraphy-Continued.

Oregon, Cascades: Smith, SS4.

Porto Rico, Coamo-Guayama region: Hodge, 443.

San Juan district: Semmes, $\$ 45$.

Santo Domingo: Maury, 650 .

Saskatchewan, southern: Davis, 233.

South Dakota, Black Fills region : Darton, 228.

Texas, northeastern: Stephenson, 909.

Utah, Morgan County, Lost Creek field: Clark, 175.

Washington, Oligocene: Van Winkle, 974.

Quincy Talley: Schwennesen and Meinzer, S37.

Wyoming, Hanna Basin : Bowen, ss.

Park Connty: Mooly and Tali: ferro, 688 .

Salt Creek oil field: Wagemann, 1010.

western: Schultz. 833.

Paleontology.

California, San Lorenzo series: Clark, 172.

Carrizo Creek fauna, California : Dickerson, 253.

Colorado, Paleocene bat: Matthew, 639.

Raton flora: Knowlton, $\mathbf{5 3 5}$.

San Juan Basin: Granger, 537.

Costa Rica, Bryozoa: Canu and Bassler, 153.

Eagle Creek flora, Columbia River gorge : Chaney, 166.

Equidae, revision : Osborn, 723.

Florida, Volusia County, Mollusca : Mansfield, 619.

Foraminifera, Coastal Plain: Cushman, 215.

Georgia, Claiborne and Jackson deposits: Cooke and Shearer, 206.

Idaho formation fauna: Merriam, 661.

Meganos group, Eocene, California: Clark, 171.

Montana; northeastern: Collier and Thom, 201.

New Mexico, Raton flora: Knowlton. 535.

San Juan Basin: Granger, 357.

Oklahoma, Plantae: Berry, 69.

Panama Canal Zone, Bryozoa: Canu and Bassler, 153.

Foraminifera: Cushman, 216.

Porto Rico: Reeds, 776.

Wasington, Oligocene: Vàn Winkle, 974.

Wyoming, Notharctus: Granger and Gregory, $\mathbf{3 5 9}$.

Tezas.

General.

Geological mapping: Urden, $95 \mathrm{~S}$.

Survey report, 1915: Stiles, 914. 
Texas-Continued.

Économic.

Coal, Webb County: Ashley, 24.

Colorado coal field: Drake, 266.

Glass Mountains: Udden, 959.

Manganese, Shumla: Roberts and Nash, 794.

Oil fields, north central Texas : Hager, 388.

Oil pools, Gulf Co:st country : Matteson, 634 .

Oil possibilities, Wise County: Böse, S5.

I:etroleum : Deussen, 251.

north-central Texas: Kempher, 504.

Runnels County: Beede and Waite,

i 59.

Salt domes, origin: Dumble, 272 ; Rogers, s03.

Salt dome structure: Lucas, 594.

Santo Tomas cannel coal, Webb. County : Ashley; 24.

Sulphur, trans-Pecos region: Thomas; 942.

Thrall oil field: Udden, 960.

Val Verde County :. Roberts and Nash, 794.

Dynamic and structural.

Caves: Bailey, 31.

North central Texas: Hager, 385 .

Salt domes, origin : Dumble, 272.

Trans-Pecos Texas, front range: Baker and Bowman, 32.

Tise County, Bridgeport and Chico: Böse, 85 .

\section{Physiograinhic.}

Citmp Bowie area: Shuler, 86t.

Sau Antonio rerion: Stephenson, 9os.

Trans-Pecos Texas, front range: Baker and Bowman, 32.

\section{stratigraphic.}

Camp Bowic arca : Shuler, S64.

Colorado coal field: Drake, 266.

Glass Mountains: Udden, 959.

Ilano series, age: Farrell, 40.

North central Texas: Hager, 388 ; Kempher, 504.

Northeastern 'Texas: Stephenson, 909.

Oil fields, north central Texas: Hager, 3ss.

Oil pools, Gulf const country: Matteson, 634 .

runnels County: Bcede and Waite, 59.

San Antonio area : Muir, 700.

Thrall oil field: Ddden, 960 .

Trans-Pecos Texas, front range : Baker and Bowman, 32.

Val Verde County: Roberts and Nash, 794.

Wise County; Brldgeport and Chico: Böse, S5.

Paleontology.

Edaphosaurus, Archer County: Case, 157.
Texas-Continued.

IIneralogy.

Meteorites, Fayette County: Merrill, 665.

Plainview : Merrill, 664.

Underground vater.

San Antonio area: Muir, 700:

Val Verde County: Roberts and Nash, 794.

\section{Textbooks.}

Crystallography: Butler, 189.

Economic geology : Emmons, 292.

Geometrical crystallography: Butler, 138.

Military geology and topography : Gregory, et al.; 368 .

Mineralogy: Butler, 139.

Organic evolution: Lull, 507:

Tin.

General: Boalich and Castello, 84; Knopf, 582, 5:3.

Virginia, Irish Creek: Ferguson, 804, $305,306$.

Tintic distlict; Utah: Tibby, 946.

Titanic iron ores, microstructure: Warren, 994.

Travertine deposits, Arbuckle Mountains, Oklahoma : Emig, 289, 290.

Triassic.

stratigraphy.

Alaska, Chitina Valley : Mofit, 6\$3.

Gravina and Revillagigedo islands: Chapin, 167.

Nelchina-Susitna region: Chapin, 168.

Alberta, I'eace Rivel scction : McIenrn, 610.

Arctic regions, Ellesmere and Grinnell lands: Holtedahl, 447.

British Columbia, Vancouver area: Burwash, 135.

California, Inyo Range: Kirk, 510.

Idaho, southeastern : Schultz, 8:33.

Montana, southwestern: Condit, 202.

Nevada, Yerington district: Knopf, 528.

Pennsylvania, easteru: Jonas, 485.

South Dakota, Black Fills region : Darton, 228.

Dtah, Green River desert: Emery, 288.

Wyoming, western: Condit, 202; Schultz, 833.

\section{Paleontology.}

Alaska, Isocrinus: Batber, 56.

Pennsylvania, Rutiodon: Sinclatr, 867.

\section{Trilobita.}

Appendages: Walcott, 9SS.

Phacopidae: McLearn, 612.

\section{Tripoli.}

Oklahoma: Perry, 752.

Tully limestone and Genesee shale, relationship: Grabau, $3 \overline{5}$. 
Tungsten.

General: Runner and Hartmann, 810 . Bibliography: Hartmann, 407.

Ores: Anon., 1092.

Alaska, Fairbanks: Bateman, 52.

Californial: Boalich and Castello, 83.

Canada: Malcolm, 616.

Manitoba, Falcon Lake: DeLury, 249.

South Dakota, Black. Hills: Runner and Hartmann, 810.

Turtles. See Reptilia.

\section{Unconformities.}

Cretaceous-Tertiary : Lee, 554.

Jip of marine limestone strata: Mather, 627 .

Underground water (general). See also Geysers; Mineral waters; Springs; Thermal waters. For regional see names of States.

Ribliography : Meinzer, 635 .

Water table, oscillations: Emmons, 203.

\section{Uranium.}

General: Cahen, 144.

Ungulata. See Mammalia.

Upper Silurian. See Silurian.

Utah.

Économic.

Carnotite deposits, southwestern Utah : Kithil and Davis, 522.

Coal, Lost Creek field, Morgan County : Clark, 175.

Copper, Tooele County: Kemp and Billingsley, 503.

Gold, silver, copper, lead, and zinc in 1916 : Heikes, 426.

Good Hill area, Tooele County : Kemp and Billingsley, 503.

Oil sh:lles: Adkinson, 4 ; Ziegler, 1089.

Uinta Basin: Winchester, 1065.

I'hosphate, Uinta Mountains: Schultz, 834.

Tintic district, Utah: Tibby, 946 .

Üranium-vanadium ores, origin : Notestein, 714

Dynamic and stivetural.

Cintal Mountains, structure: Schultz, 834.

Valley City graben: Duke, 219.

I'hl/siographic.

Lake Bonneville, age: Keyes, 510.

Valley City graben: Dake, 219.

Stratigraphic.

Green River Desert section: Emery, 2S8. -

Lost Creek coal field, Morgan County; Clark, 175.

Santaquin and Mount Nebo region: Loughlin, 589.

Uinta Basin: Winchester, 1065.

Uinta Mountains: Schultz, \$34.

Valley City area, Grand County : Dake, 219.

Paleontology.

Artionactyla, Uinta Básin: Peterson,
Utah-Continued.

Petrology.

Gold Hill area, Tooele County : Kemp and Billingsley, 503.

Lamprophyre dikes, Santaquin and Mount Nebo region, Loughlin, 589.

Mineralogy.

Mimetite: Wherry, 1020.

Racewinite, Bingham: Winchell, 1061.

'Tungstenite, Little Cottonwood district: Kuhre, 539; Wells, 1014.

Vanadium.

General: Boalich and Castello, S3.

Source of vanadium in sedimentary rocks : Phillips, 754.

Veins,

Formation, New York : Taber, 926.

Vermont.

Jiconomic.

Manganese, South Wallingford: Jones, 488.

Stratigraphic.

Cuttingsville: Eggleston, 277.

Glaciation, Wilmington area: Hubbard, 463 .

Ordovician, central Vermont: Richardson, 788.

Petrology.

Eruptive rocks, Cuttingsville : Eggreston, 277.

Vertebrae, evolution: Williston, 1055.

Vertebrata (general): See also Amphibia; Aves; Mammalia ; Pisces; Reptilia.

Nomenclature of cranial elements in I'ermian Tetrapoda: Gregory, 369.

Alberta : Sternberg, 911.

Montana, northeastern; Collier aur Thom, 201.

Vertebrate paleontology, development: Lull, 601.

Virginia.

Economic.

Coal, Buchanan County : Hinds, 439.

Copper, southwestern Virginia: Haney, 396.

Emery: Watson and Steiger, 1.008.

Manganese, Frederick.County : Haney, 397.

Shenandoah Valley: Hewett et al., 433.

Pyrrhotite, southwestern Virginia: Van Mater, 969.

Salt deposits, southwestern Virginia, origin: Thomas, 940.

Tin, Irish Creek: Ferguson, 304, 305, 306.

Titanic iron ores, microstructure: Warreu, 994.

Dynamic and structural.

. Cr. Eatitiquale, April 9, 1918: Watson, 1006. 
Virginia-Continued.

\section{- Physiographic...}

Camp Lee region: Giles, 336.

Eastern Virginia: Giles; $\mathbf{3 3 6 .}$

Langley field, Hampton quadrangle, Virginia: Stephenson, 907.

\section{stratigraphic.}

Buchanan County: Finds, 439.

Irish Creek: Ferguson, 306.

Ordovician, l'iedmont: Bassler, 47, 48.

Rock emery area, Pittsylvania County : Watson and Steiger, 100s.

Rockbridge County, Irish Creek: Ferguson, 304.

Jetrology.

Spinellite: Watson and Steiger, 1008. Mineralogy.

Amelia Court House:- Gordon, 346.

Pyrolusite, Shenandoah Co.: Watson, 1005 .

Volcanic Jocks. See Igneous and volcanic rocks.

Volcanism.

Eruption centers, regularity of intervals: Friedlaender, 322.

Volcanoes.

General : Anderson, 1s ; Jagger, 469.

Alaska: Dall, 220.

Katmai, eruption: Griggs, 372, 373.

Ten Thousand Smokes: 'Griggs, 374.

hot mud flow : Griggrs, 375.

California, Lassen Feak: Sapper, 815.

Guatemala : Sapper, 814.

Hawail : Jagger, 469.

Kilauea, model: Daly, 224 ; Sayles, 819.

Irazi, Costa Rica, eruptions, 1917-18 : Calvert, 145.

Quetzaltepeque, San Salvador, eruption : Lacroix, 542.

San Salvador, eruption, June, 1917: Friedlaender, 323 ; Powers, 763.

War minerals: Leith, 560 ; Spurr, 898.

War work, geological: Meinzer, 654 ; Smith, 881 .

Washington.

Geniral.

Survey report, 1915-17: Wash. G. S., 1000.

Economic.

Colville Inclian Reservation: Pardee, 741.

Epsomite lake: Jenkins, 475.

Fold, silver, copper, lead, and zinc, 1916: Gerry, 331.

Magnesite: Stone, 918, 919.

Magnesite Valley: Jenklns, 474.

Manganese, northern Washington: Jenkins, 473.

Ores, coals, and useful rocks: Roberts et al., 795 .

Physingraphic.

Big-Bend region: Meinzer, 656 .

Camp lewis and vicinity wejghton, 559.
Washington-Continued.

Physiographic-Continued.

Colville Indian. Reservation: Pardee, 741.

Columbia River gorge: Chaney, 166.

Epsomite lake: .Jonkins, 475.

Mount Rainiel National Park: Matthes, 636 .

Western Washington : Jeighton, 559.

Stratigraphic.

Big Bend l'egion: Melnzer, 656.

Columbia River gorge: Chaney, 166.

Colville Indian Reservation: Pardee, 74.1.

Franciscan sandstone: Davis, 230.

Oligocene: Clark and Arnold, 173; Van Winkle, 974.

Oligocene paleogeography: Weaver, 1009.

Polter Creek beds: Van Winkle, 975.

Quincy Valley : Schwennesen and Meinzer, 837.

Paleontology.

Eagle Creek flora, Columbia River gorge: Chaney, 166.

Oligocene: Van Winkle, 974.

Porter Creek beds: Van Winkle, 975. Underground water.

Quincy Valley : Schwennesen and Melnzerr, 837 .

Water surfaces in oil fields: Daly, 223.

Well records. Sce borings.

West Indies (general). See also names of islands.

Stratioraphic.

'Tertiary, correlation: Vaughan, 979.

West Virginia.

Eiconomic.

Barbour County : Reger and Teets, 778.

Geologic map: White et al., 1037.

Natural gas: White, 1032.

Petroleum: White, 1032.

Raindolph County, western part: Reger and 'leets, 778.

Upshur County : Reger and Teets, 778.

Dynamic and structural.

Kanawha black flint: Pice, 768.

Temperature in deep wells: Van Orstrand, 970 .

Stratigraphic.

Barbour County : Reger and Teets, 778.

Boring, Clarksbur, Harrison County : White, 1033.

Deep wells: White, 1036 .

Geologic map: White et al., 1037.

Randolph County, westerù part: Reger and Teets, 778 .

Upshur County : Reger and Teets, 778.

Paleontology.

Conemaugh and rottsville faunas: Price, 767.

Wind work.

Desert depressions, origin : Hobbs, 442.

Dustfalls, March, 1.918: Winchell and Miller, 1063. 
Wind work-Continued.

Louisiana loess, origin: Emerson, 286.

North Dakota, valley filling: Collier, 198.

Wisconsin.

General.

Soils, Columbia Co.: Whitson et al., 1041.

Jefferson County: Thitson et al., 1040.

northeastern Wisconsin: Whitson et al., 1039.

north central Wisconsin: Whitson et al., 1042.

Survey report, 1916-18: Wis. G. S., 1068.

Physiographic.

Southeastern Wiseonsin: Alden, S.

Terraces, Mississippi Rizer : Martin, 624.

\section{Stratigraphic.}

Quaternary geology, southeastern Wisconsin: Alden, S. .

Southeastern Wisconsin: Alden, 8 .

Mineralogy.

Fluorite in Ordovician limestones: Bagg, 29.

Fluorspar in Ordovician limestone, Neenah : Bagr, s0.

Wood replaced by calcite: Greenland, 364.

Wyoming.

Gencral.

Bibliography : Borce, 86.

Economic.

Cretaceous oil and gas fields: Trumbul1, 955 .

Petrolenm, Salt Creck field : Wegemann, 1010.

Phosphate and coal, western Tyoming: Schultz, 833 .

Platinum : Taft, 928.

Titanic iron ores, microstructure: Warren, 994.

Western Wyoming: Schultz, 833 .

Dynamic and structural.

General: Darton, 227.

Hart Mountain orerthrust, Park County: Dake, 218.

\section{Stratigraphic.}

General : Darton, 227.

Amsden formation, Wind River Moun. tains: Branson and Greger, 103.
Wyoming-Continued.

Stratigraphic-Continued.

Hanna Basin : Bowen, 8s.

Medicine Bow Range: Blackwelder and Crooks, $7 \mathrm{~S}$.

Iorrison formation, ase: Schuchert, 830 .

Oolites, Wind River Mountains : Tarr, 938.

Park County : Dake, 218.

Salt Creek oil field: Wegemann, 1010.

Sunshine, Park County, anticlines: Moody and Taliaferro, 6Ss.

Western Wyoming: Blackwelder, $i 6$; Condit, 202 ; Schultz, \$33.

\section{Paleontology.}

Amsden formation, Wind River Mountains: Branson and Greger, 10:?.

Diatryma, Bighorn Basin: Matthew and Granger, 64S.

Notharctus: Granger and Gregory, 359.

Stegosaurus: Gilmore, 338.

Yukon.

Economic.

Gold. Sixtymile and Ladue valles: Cockfield, 191.

Sixtymile and Ladue vallers: Coc': field, 191.

Stratigraphic.

Sixtymile and Ladue valless : Cockfield, 191.

Zinc.

California, Inyo Range: Knopf, 527.

Central States: Dunlop and Butler. 274 .

Colorado: Henderson, 42s.

Jeadville: Loughlin, 500.

Fastern States: Hill, 436 .

Idaho: Gerry, 331.

Missouri-Kansas-Oklahoma zinc district: Wright, $107 \mathrm{~S}$.

Nevada: Heikes, 427.

Clark County, Yellow Pine district: Hale, 389.

New York, St. Lawrence County, Edwards district: Smyth, SST.

Quebec, Gaspe County, Lemieux: Mailhiot, $61 \overline{5}$.

Utah : Heikes, 426.

Washington: Gerry, 331.

Zircon.

General: Schaller, 821. 


\section{LISTS.}

(The numbers refer to cntries in the biblingraphy.)

\section{chemical analyses.}

Absarckitc, 589.

Algae, 977.

Alluvium, 850 .

Amadorose, 135.

Andose, 277.

Arkose, 412.

Augite syenite, 277.

Barkevikite, 277 .

Beerbachose, 135.

Beryl, 1069.

Bindheimite, 529.

Biotite granite, 412.

Bottom deposits, 977 .

Cassiterite, 306.

Cave deposits, 340.

Chromite, 761.

Clay, 233.

Coal, 24, 175, 439, 833.

Colerainite, 761 .

Corallinaceae, 977.

Diabase, 412, 761.

Diopsille, 761.

Dolomite, 343, 932.

Imery, 1008.

Essexite, 277.

Euxenite, 674 .

Felsite, 528.

Foraminifera, 977 .

Gabbro, 377, 3s2, 412, 596.

Garnetite, $52 s$.

Granite, 412, 527.

Granite aplite-pegmatite, 1008.

Graphite ore, 16.

Grossularite, 761 .

Hematite, 1069.

Hetacrolite, 590 .

Hornblende, 277.

Ilmenite, 994.

Ilvaite, 847.

Invertebrate skeletons, 977.

Iron ore, $710,797$.

Keratophyre, 528, 596 .

Kersantite, 589.

Limprophyre, $\mathbf{5} 89$.

Iaterites, 672.

Iaurvikose, 277.

Lava, 52 .

Limestone, 213, 528.

Limonite ore, 310 .

Litchfieldite, 226 .
Loess, 606, $\cong 50$.

Magnetite, 994.

Mine waters, 51.

Miaskose, 277.

Minette, 412.

Mullanite, $8 \pm 6$.

Nordlmarkosc, 277.

Novaculite, 82.

Olivine gabbro, 596 .

Oolite, 977.

Ouralite porphyry, 596.

Peridotite, 310, $\mathbf{7 6 1 .}$

Petroleum, 606.

Phlegrose, 277 .

Phosphate rock, 83:3, 834.

Flumbojarosite, 590 .

I'seudo-diorite, 412.

P'ulaskite, 277.

Fulaskose, 277.

Pyrolusite, 1005.

Pyroxene, 528.

Pyroxenite, 761.

Quartz, fibrous, 41.1.

Quartz diorite, 135.

Quartz keratophyre, 596.

Quartz monzonite, 527.

Racewinite, 1061.

Rhyolite, 528 .

Rubellite, 106?.

Schist, 412.

Serpentine, 761.

Serpentine rock, 310 .

Shale, 412, 606.

Slate, 858.

Spinel, 1008 .

Stichtite, 761 .

Strontianite rock, 530 .

Sudbury ores, 791 .

Syenite, 277.

Tinguaite, 277.

Tripoli, 752.

Tungstenite, 5is.

Vesuvianite, 761 .

Vivianite, 1007.

Washingtonite, 994.

Wernerite, 1069.

Wolframite, 800 .

Zinciferous clay, 500 .

Zoisite, 1069. 


\section{MINERALS DESCRIBED.}

Alabandite, 15.

Amphibole, 761 .

Apatite, 96,761 .

Aragonite, 761 .

Argentite, 51.

Argyrodite, 51.

Alsenopyrite, $51,848$.

Augite, 96.

Aurichalcite, 590.

Beryl, 444, 546, 1069.

Braunite, 15, 923.

Brucite, 761, 799.

Calamine, $\mathbf{5 9 0}$.

Calcite, 96, 590, 761 .

Cerusite, 550, 945.

Cervantite, 848 .

Chalcophanite, 590.

Chalcopyrite, 51, 761 .

Chalmersite, 478 .

Chlorite, 96.

Chromite, 761.

Chrysotile, 761.

Clinochlore, 761.

Colemanite, 318.

Colerainite, 316, 760, 761.

Collbranite, 316.

Copiapite, 605.

Cristobalite, 798.

Cronstedtite, 441.

Diamond, 761 .

Diopside, 761.

Dolomite, 96, 761 .

Electrum, 51.

Epj,dote, 96.

Epsomi ${ }^{+}$e, 475.

Euxenite, 674.

Feldspar, 96.

Fluorspar, 30.

Gageite, 569.

Galena, 51.

Galnet, 96, 761 .

Gilpinite, 316.

Hematite, 96, 1069.

Hetacrolite, 590.

Hornblende, 96 .

Ifydiromagnesite, 761.

Hydrozincite, 590.

Ilmenite. 994.

Ilvaite, 847.

Kaolinite, 96.

liermesite, 848.
Grossularite, 761.

Kieserite, 475.

Lazulite, 667.

Limonite, 96.

Magnetite, 96, 761, 994.

Manganese, 923 .

Manganite, 15.

Marcasite, 96.

Mica, 96.

Mimetite, 1020.

Mclybdenite, 761 .

Mullanite, $316,846$.

Olivine, 96.

Opal, 663.

Fericlase, 799 .

Picrolite, 761.

Plumboparosite, 590.

Polybasite, 51.

Porcellophite, 761 .

Psilomelane, 15, 923.

Pyrargyrite, 51.

Pyrite, 51, 96, 539, 848 .

Pyrolusite, 15, 923, 1005.

Quartz, 96, 761.

Quartz, fibrous, 411.

Racewinite, 1061.

Rhodochrosite, 15, 923.

Rhodonite, 15.

Rubellite, 1069.

Scolecite, 761.

Serpentine, 310, 761.

Smithsonite, 590.

Sphalerite, 51, 848 .

Tourmaline, 549, 761, 967.

Sphene, 96.

Stibioferrite, 848 .

Stibnite, 848.

Stichtite, 761 .

Strontianite, 530.

Talc, 96.

Thaumasite, 1020.

Tungstenite, 316, 538, 1014.

Ulexite, 318.

Valen tinite, 848 .

Vesurianite, 761 .

Vivianite, 1004, 1007.

Volgerite, 848.

Wad, 15, 923.

Wavellite, 1020.

Wernerite, 1069.

Wolframite, 51.

Zircon, 96, 761.

Zoisite, 1069.

\section{ROCKS DESCRIBED.}

Andesite, $\mathbf{7 4 1}$.

Audesite porphyry, 783 .

Anorthosite, 17.

Aplite, 96, 761 .

Augite syenite, 277.

Basalt, 96, 527, 741.

Cumberlandite, 994.

Diabase, 17, 96, 485, 761 .

Diorite, 96, 135, 485, 527, 741.

Dolomite, 96.
Essexite, 277.

Gabbro, 17, 96, 4S5, 596, 741, 761.

Gneiss, 17, 377.

Granite, 17, 96, 485, 527, 761 .

Granodiorite, 135.

Lamprophyre, 741.

Latite, 527.

Limestone, 96, 277.

Litchfieldite, 226.

Nordmarkite, 277. 
Oliviue gabbro, 596.

Ouralite porphyry, 596.

Pegmatite, 17.

Peridotite, 761.

Phonolite, 17.

Porphyrite, 761 .

Porphyry, 741.

Pulaskite, 277.

Pyroxenite, 761.

Quartz diorite, 135.

Quartz keratophyre, 596.
Quartz monzonite, 527.

Quartz porphyry, 783 .

Rhyolite, 17, 527.

Sandstone, 96.

Schist, 17, 783.

Serpentine, 741, 761.

Syenite, 17, 96, 277.

Tinguaite, 277.

Trachydolerite, 17.

Trachyte, 17.

Tuff, 17.

\section{GEOLOGIC FORMATIONS DESCRIBED.}

Abilene conglomerate member, Permian, Kansas: Moore and Haynes, 697.

Abitibl group, pre-Cambrian, Quebec: Wilson, 1058 .

Adams Branch limestone, Carboniferous, Texas : Drake, 266.

Adaville formution (?), Cretaceous, Wyoming: Schultz, 833.

Admiralty till, Pleistocene, British Columbia: Burwash, 135.

Adimire shale member, Pennsylvanian, Kansas: Moore and Haynes, 697.

Agawa formation, pre-Cambrian, . Minnesota : Harder and Johnston, 403.

Alazan shales, :Eocene, Mexico: Dumble, 271.

Albany division, Carboniferous, Texas: Drake, 266.

Allogheny formation, Pennsylvanian, Maryland: Clark et al., 179.

Allegheny formation, Pennsylvanian, Pennsylvania: Butts, 142.

Allegheny series, Pennsylvanian, West Virginia: Reger and-Teets, 778.

Almy formation, Tertiary, Wyoming and Idaho: Schultz, 833 .

Altamont limestone, Oklahoma : Cullen, 213.

Altamont limestone member, lennsylvanian, Kansas : Moore and Haynes, 697 . .

Alum Bluff formation, Miocene; Florida : Sellards and Gunter, 842.

A mericus limestone member, Fennsylvanian, Kansas: Moore and Haynes, 697.

: Ames limestone and shale; Pennsylvanian,

- West Virginia : Reger and Teets, 778.

Amisk . group, pre-Cambrian, Mànitoba : Bruce, 113.

Amisk volcanics, pre-Cambrian, Saskatchewan: Bruce, 111.

Amnicon formation, pre-Cambrian, Minnesota : Harder and Johnston, 403.

- Amsden formation, .. Carboniferous, Wyoming: Branson and Greger, 103; Condit, 202.

Anguilla formation, Tertiary, West Indies : Vaughan, 979.

Ankareh shale, Triassic, Wyoming and Idaho: Schultz, 833.

Annabelle shale, Pennsylvanian, West Virginia: Reger and Teets, 778.

Annona tongne. Cretnceous, Iexas: Stephenson, 909 .

$$
122541^{\circ}-19-9
$$

Antelope Creek bed, Carbontferous, Texas ; Drake, 266.

Anticostian, Silurian, New York: Chadwick, 158.

Antietam formation, Cambrian, Marylind : Clark et al., 179.

Apison shale, Cambrian, Georgla : Shearer, 858:

Aquia formation, Tertiary, Maryland : Clark et al., 179 ; Little, 577.

Arbuckle limestone, Oklaboma : Cullen, 213.

Arecibo formation, Tertiary, Porto Rico: Semmes, 845.

Arisalg series, Silurian, Nova Scotin: McLearn, 611 .

Arnoldsburg sandstone, Pennsylvanian, West Virginia: Reger and Jeets, 778.

Arroyo formation, Permian, Texas: Beede and Waite, 59. …

Arundel formation, Cretaceous, Maryland: Clark et al., 179 ; Little, 577 .

Ashokan beds, Devonian, New York: Grabau, 355.

Aspen formation, Cretaceons, Wyoming und Idaho: Schultz, 833.

Austin chalk, Cretaccous, Jexas: Stephenson, 909

Aux Vases sandstone, Mississippian, Illinois : Ulrich, 962.

Avant limestone, Carboniferous, Oklahoma: Emery, 287 ; Cullen, 21.3 ; Greene, 36.3 ; Lloyd and Mather; 579.

Axeman limestone, Canadian, Pennsylvania : Butts, 142.

Bailey formation, Devonian, Missouri : Bronson, 102.

Baltimore gnelss, pre-Cambrian, Marylana : Clark et al., 179.

Bandera shaje member, . Pennsylvanian, Kansas: Moore and Haynes, 697.

Baraboo quartzite, pre-Cambrian, Wisconsin : Alden, 8.

Barnwell formation, Eocene, Georgin: Cooke and Shearer, 206.

Bartlesville sand, Pennsylvanian, Oklaho. ma: Greene, 363.

Bashi. formation, Tertiary, Alabama: Hayer, 387.

Bayfield group, pre-Cambrian. Minnesota: Harder and Tohnston, 403.

Bays sandstone, Ordovician, Virginia : Hinds, 434 . 
Raytown limestone, Pennsylvanian, Missouri : Wilson, 1057.

Bead Mountain bed, Carboniferous, Texas: Drake, 266.

Bead Mountain formation, Permian, Texas : Beede and Waite, 59.

Bear Branch member, Devonian, Tennessee : Dunbar, 273.

Bear Creek Shale, Silurian, New York: . Chadwick, 158.

Bearpaw formation, Cretaceous, Alberta : Allan, 12.

Bearpaw shale, Cretaceous, Montana: Bowen, 92 ; Collier, 200 ; Hancock, 395 ; Stebinger, 915.

Bear River formation, Cretaceous, Tyoming and Idaho: Schultz, 833.

Beaver limestone, Cambrian, Georgia: Shearer, 858.

Beaumont clay, Tertiary, Gulf coast : Matteson, 634 .

Beckwith formation, Jurassic, Wyoming and Idaho: Schultz, 833,

Beeckbill formation, Silurian, Nova Scotia : McLearn, 611.

Peekmantown limestone, Ordovician, Maryland : Clark, et al. 179.

Bejucal limestones, Eocene (?), Cuba : DeGolyer, 241.

Belcher series, pre-Cambrian, Belcher Islands, Canada: Moore, 693.

Bellefont dolomite, Canadian, Pennsylvania : Butts, 142.

Belly River series, Cretaceous, Alberta: Allan, 12.

Belt series, Algonkian, Montana: Pardee, 738.

Bend formation, Mississippian, Texas: Kempher, $50 \pm$.

Bend series, Mississippian, Texas: Hager, 388.

Bennington limestone, Oklahoma: Cullen, 213.

Benton formation, Cretaceous, Colorado, New Mexico: Lee, 554.

Benton formation, Cretaceous, Colorado: Ziegler, 1091.

Benton formation, Cretaceous, Kansas: Moore and Haynes, 697.

Benton group, Cretaceous, Kansas: Perrine, 751.

Benton shale, Cretaceous, Wyoming: Wegemann, 1010.

Benwood limestone, Pennsylvanian, West Virginia : Reger and Teets, 778.

Bethany Falls limestone, Pennsylvanian, Kansas: Moore and Haynes, 697.

Bethany Falls limestone, Pennsylvanian, Missouri : McCourt, 606; Wilson, 1057.

Bethel sandstone, Mississippian, Kentucky and Illinois: Butts, 140.

Big Basin sandstone member, Permian, Kansas: Moore and Haynes, 697.

Big Blue group, Permian, Kansas: Moore and Haynes, 697.
Bigheart -sandstone, Pennsylvanian, Okla: homa : Bowen, 89 ; Emery,' 287; Hopkins, 454 .

Bighorn dolomite, Ordovician; Wyoming Blackkwelder, 76.

Bighorn dolomite, Ordovician, Wyoming and Idaho: Schultz, 833.

Big Valley beds, Carboniferous, Texas: Drake, 266.

as

Bingen formation, Cretaceous, Arkansas: Miser and Purdue, 680.

Birch Creek limestone, Pennsylvanian, Oklahoma: Bowen, 89.

Birch Isake sandstone, Cretaceous, Alberta: Slipper, 871.

Bird Creek limestone, Carboniferous, Oklahoma: Bowen, 91; Heald and Mather, 425.

Birdsong formation, Devonian, Tennessee : Dunbar, 273.

Birdsville formation, Mississippian, Illinols and Kentucky: Ulrich, 962.

Birdsville group, Mississipplan, Illnois and Kentucky, Ulrich, 962.

Birmingham shale, Pennsylvanian, West Virginia: Reger and Teets, 778 .

Biwabik formation, pre-Cambrian, Minnesota : Harder and Johnston, 403.

Blackleaf sandy member,j Cretaceous, Montana : Stebinger, 915 .

Blaine formation, Permian, Oklahoma : Aurin, 27.

Blossom sand, Cretaceous, Texas: Stephenșon, 909.

Bluff Creek bed, Carboniferous, Texas : Drake, 266.

Boiș d'Arc limestone, oklahoma: Cullen, 213.

Bolivar fire clay, Pennsylvanian, West Virginia : Reger and Teets, 778.

Bonita sandstone, Mesozoic, California : Davis, 230.

Bonterre formation, Cámbrian, Missourl : Bransoń, 102.

Boone chert, Mississippian, Kansas and Oklahoma: Berger, 64.

Boone formation, Oklahoma : Cullen, 213.

Boone formation, Mississippian, Oklahoma : Perry, 752.

Bosque diviston, Cretaceous, Texas: Drake, 266.

Bowling Green limestone, Silurian, Missouri : Branson, 102.

Brallier shale, Devonian, Pennsylvania : Butts, 142.

Brandywine 'formation, Tertiairy, Maryland : Clark et al., 179.

Brandywine formation, Tertiary (?), Maryland : Little, 577.

Brazer limestone, Carbontferous, Wyoming and Idaho: Schultz, 833,

Brewerton shale, Silurlan; : New York : Chadwick, 158.

Brewster formation, Upper Cambrian, Texas : Baker and Bowman, 32.

Bridgeport limestone, Carboniferous, Texas : Böse, 85. 
Bridger formation, Tertiary, Utah: Winchester, 1066.

Bright Angel formation, Cambrian, Ari\%ona: Schuchert, 829.

Britannia formation, Carboniferous, British Columbia: Burwash, 135. . .

Brookhaven terrace deposits, Mississippi Valley: Shaw, 850 .

Brosseau formation, Cretaceous, Alberta : Allan, 12. :-

Brown Creek bed, Carboniferous, Texas: Drake, 266.

Brownstown marl, Cretaceous, Arkansas: Miser and Purdue, 680.

Brownstown marl, Cretaceous, Texas: Stephenson, 909.

Brownwood bed, Carboniferous, Texas: Drake, 266.

Brule clay, Tertiary, South Dakota: Darton, 228.

Brunswick conglomerate, Triassic, Pennsylvania: Jonas, 485.

Brunswick shale, Triassic, Pennsylvania: Jonas, 485.

Brush Creek limestone and. shale, Pennsylvanian, West Virginia: Reger and Teets, 778. .

Buck Point sandstone, Carboniferous, Oklahoma : Clatk, '174.

'Suda limestone, Cretaceous, Texas: Roberts, 794.

Buffalo sandstone, Pennsylvanian, West Virginia : Reger and Teets, 778.

Buffalo Creek bed, Carboniferous, Texas : Drake, 266. '

Buffalo Wallow formation, Mississippian. Kentucky and Illinois: Butts, 140.

Bull Creek sandstone, Carboniferous, Toxas: Drake, 266.

Bull Creek limestone, Pennsylvanian, Oklahoma : Greéné, 363.

Bull Mead Mountain sandstone, Cretaceous, Alberta : McI.earn, 610.

Bullwagon formation, Permlan, Texas : Beedo and Waite, 59.

Bulwark sandstone, Cretaceous, Alberta : Slipper, $\mathbf{8 7 1}$.

Burket black shale member, Devonian, Pennsylvania : Butts, 142.

Burlingame limestone member, Pennsylvanian, Kansas: Moore and Havnes. 697.

Burlington limestone, Mississippian, Missouri : Branson, 102.

Burlington limestone, Misisissippian, Missouri and Iowa: Van Tuyl, 972.

Burnt Branch bed, Carboniferous, Texas : Drake, 266.

Bushberg sandstone, Mississippian, Missouri : Branson, 102.

Byram calcareous marl, Alabama and Mississippi : Cooke, 205.

Byron beds, Silurian, Wisconsin : Alden, 8.

Calnallos novaculite, Devonian (?), Texas : Biker and Bowman, 32.

Caddo limestone, Oklahoma: Cullen; 213.
Cahil sandstone, Mesozoic, California : Davis, 230.

Calera limestone, Mesozolc, California : Davis, 230, 232.

Calhoun shale member, Pennsylvanian, Kansas: Moore and Haynes, 697.

Calloway limestone, Devonian, Missourl: Branson, 102.

Calvert formation, Tertiary, Maryland : Clark et al., 179; Little, 577.

Camajuani formation, Cretaceous, Cubi: : DeGolyer, 24.1.

Camblen chert, Devonian, Tennessee: Dunbar, 273.

Camp Colorado bed, Carboniferous, Texas : Drake, 266.

Camp Creek bed, Carboniferous, Texas: Drake, 266.

Campito sandstone, Cambrian, California: Kirk, 519.

Canton terrace deposits, Mississippi Valley : Shaw, 850.

Canyon division, Carboniferous, Texas: Drake, 266.

Canyon formation, Pennsylvanian, Texas : Kempher, 504.

Caprinil limestone, Cretaceous, Texas: Drake, 266.

Carbondale formation, Carboniferous, Illi. nois : Cady, 143.

Carbondale formation, Pennsylvanian, Kentucky : Lee, 552.

Cardiff quartzlte, Ordovician (?), Maryland : Clark et al., 179.

Carllle shale, Cretaceoús, Colorado: Ziegler, 1091.

Carlile shale, Cretaceous, South Dakota: Darton, 228.

Carlile shale, Cretaceous, Wyoming: Bowen, 88.

Carlile shale member, Cretaceous, Kansas : Moore and Haynes, 697.

Carlim limestone, Ordovician, Pennsylvania: Butts, 142.

Carolina gneiss, pre-Cambrian, Georgia : Shearer and Hull, 859.

Cartersville formation, Cambrian, Georgia : Shearer, 858.

Carterville formation, Mississippian, Missouri : Branson, 102.

Caseyville sandstone, Pennsylvanian. Kentucky: Lee, $\mathbf{5 5 2}$.

Catahoula sandstone, Tertiary, Gulf coast : Matteson, 634 .

"Citaract" (Manitoulin) shale, Sllurian, New York: Chadwick, 158.

Catskill formation, Devonian, Pennsylvanin : Butts, 142.

Catskill series. Devonian, West Virginia: Reger and Teets, 778 .

Cave Creek formation, Fermian, Kansas: Moorc and Haynes, 697.

Cayetano formation, Cretaceous, Cuba: DeGolyer, 241.

Cedar Crove (Opper) sindstone, Pennsylva. nian, West Virginia: Reger and Teets, 778 . 
Cedar Hills sandstone member, Permian, Kansas: Moore and Haynes, 697.

Cedarton bed, Carboniferous, Texas : Drake, 266.

Cedartop gypsum member, Permian, Oklahoma : Aurin, 27.

Cedarville sandstone, Pennsylvanian, West Virginia : Regar and Teets, 778.

Cement City limestone, Pennsylvanian, IIIssouri : McCourt, 606; Wilson, 1057.

Chadron formation, Tertiary, South Dakota: Darton, 228.

Chaffin bed, Carboniferous, Texas: Drake, 266.

Chambersburg limestone, Ordovician, Maryland : Clark et al., 179.

Chaney gypsum member, Permian, Oklahoma : Aurin, 27.

Chanute shale, Pennsylvanian, Missouri : McCourt, 606 ; Wilson, 1057.

Chanute shale member, Pennsylvanian, Kansas: Moore and Haynes, 697.

Chase formation, Permian, Kansas : Moore and Haynes, 697.

Chattahoochee formation, Oligocene, Florida : Sellards and Gunter, 842.

Chattanooga. shale, Devonian, Tennessee : Dunbar, 273.

Chattanooga shale, Devonian, and (?) Mississippian, Kentucky and Illinois: Butts, 140.

$$
\because
$$

Chemung formation, Devonian; : Pennsylvania : Butts, 142.

Chemung member, Devonian, Maryland : Clark et al., 179.

Chemung series, Devonian, West Virginia : Reger and Teets, 778.

Chequamegon sandstone, pre-Cambrian, Minnesota : Harder and Johnston, 403.

Cherokee formation, Pennsylvanian, Kansas and Oklahoma: Berger, 64.

Cherokee formation, Pennsylvanian, Missouri: Wilson, 1057.

Cherokee shale, Pennsylvanian, Kansas: Moore and Haynes, 697.

Cherokee shale, Pennsylvanian, Missouri : Branson, 102 ; McCourt, 606.

Cherryvale shale, Pennsylvanian, Missouri : McCourt, 606; Wilson, 1057.

Cherryvale shale member, Pennsylvanian, Kansas: Moore and Haynes, 697.

Chesapeake group, Tertiary, Maryland : Clark et al., 179.

Cheshewalla sandstone, Pennsylvanian, Oklahoma: Winchester et al., 1067.

Chester group, Mississippian, Kentucky and Illinois : Butts, 140.

Cheyenne sandstone, Comanchean, Kansas: Moore and Haynes, 697 ; Perrine, 751.

Chickamauga formation, Ordovician, Georgia:. Shearer, 858.

Chickamauga limestone, Ordovician, Tennessee : Stose and Schrader, 923.

Chico group, Cretaceous, California: English, 294.

Chicontepec beds, Eocene, Mexico : Dumble, 271 .
Chimney Hill limestone, Oklahoma: Cullen, 213.

Chinitna formation, Jurrasic, Alaska : Chapin, 168.

Chinle formation, Triassic, Utah: Emery, 288.

Chitistone limestone, Triassic, Alaska:

- Moffit, 683 .

Choctawhatchee formation, Miocene, Florida: Sellards and Gunter, 842,

Choptank formation, Tertiary, Maryland : Clark et al., 179 ; Little, 577.

Chouteau limestone, Mississippian, Missouri : Branson, 102.

Choza formation, Permian, :Texas: Beede and Waite, 59 .

Chugwater formation, Carboniferous, Triassic, and Jurassic (?), Wyoming: Condit, 202.

Chugwater formation, Triassic, Wyoming: Bowen, 88.

Cimarron group, Permian, Kansas: Moore and Haynes, 697.

Cimarron series, Permian, Kansas: Perrine, 751.

Cisco division, Carboniferous, Texas : Drake, 266.

Cisco formation, Pennsylyanian, Texas : Kempher, 504.

Claggett formation, Cretaceous; Montana : Bowen, 92 ; Hancock, 395.

Claggett shale, Cretaceous,:. Montana : Collier, 200.

Claiborne formation, Eocene, Florida: Sellards and Gunter. 842. ;

Claiborne group, Eocene, , Georgia: ' Cooke and Shearer; 206.

Claremont shale, Miocene, California: Clark, 172.. ..:

Clarion sandstone, Pennsylvanian, West Virginia: Reger and Teets, 778.

Clarksburg fire clay shale, Pennsylvanian, West Virginia : Reger and Teets, 778.

Clarksburg limestone, Pennsylvanian, West Virginia: Reger and Teets, 778.

Clarksburg red shale, Pennsylvanian, West Virginia : Reger and Teets, 778. Hager, 387.

Clear Creek bed, Carboniferous, Texas: Drake, 266.

Clear Creek formation, Devonian, Missouri: Branson, 102.

Clear Creek sandstone, Pennsylvanian, Missouri : Greene, 363. . . : : :

Clem Creek sandstone, Carboniferous, Oklahoma : Emery, 287.

Cliff Lake granite porphyry, pre-Cambrian, Manitoba: Bruce, 113.

Clinch , sandstone, Silurian, Virginią : Hinds, 439.

Clinton formation, Silurian,. Maryland : Clark et al., 179.

Clinton formation, Silurian, Pennsylvania : Butts, 142.

"Clinton group," Silurian, New York: Chadwick, 158. 
Clore formation, Mississippian, Kentucky and Illinois: Butts, 140 ; Ulrich, 962.:

Cloverly formation, Cretaceous, Montana : Hancock, 395.

Cloverly formation, Cretaceous, Wyoming: Bowen, 88; Moody and Taliaferro, 688; Wegemann, 1010.

Cobalt series, pre-Cambrian, Ontarió: Burrows, 132.

Cobalt series; pre-Cambrian, Quebec: Wilson, 1058.

Cochahee sandstone, Pennsylvanian, Oklahoma : Winchester, et al., 1067.

Cockeysville marble, Cambro-Ordovician, Maryland : Clark et al., 179.

Cockfield formation, Tertiary, Gulf coast : Matteson, 634.

Coconino sandstone, Carboniferous, Arizona: Schuchert 828.

Cody shale, Cretaceous, Wyoming: Moody and Taliaferro, 688.

Coffeyville limestone member, Pennsylvanian, Kansas: Moore and Haynes, 697.

Coleman bed, Carboniferous, Texas: Drake, 266.

Coleman Junction bed, Carboniferous, Texas : Drake, 266.

Collingsworth gypsum member, Permian, Oklahoma : Aurin, 27.

Colorado formation, Cretaceous, Montana: Pardee, 738.

Colorado shale, Cretaceous, Montana: Bowen, 92 ; Hancock, 395; Stebinger, 915.

Columbia group, Quaternnry, Maryland : Clark et al., 179; Little, 577.

Columbia lava, 'Tertiary, Oregon: Smith, 884.

Comanche series, Cretaceous, Texas and Oklahoma : Stephenson, 909.

Comanchean system: Moore and Haynes, 697.

Comanche Crèek bed, Carboniferous, Texas : Drake, 266.

Comanche Peak limestone, Cretaceous, Texas: Drake, 266.

Conasauga formation, Cambrian, Georgia : Shearer, 858.

Concord formation, Oligocene, California : Clark, 172.

Conemaugh formation, Pennsylvanian, Maryland: Clark et al., 179.

Conemaugh series, Pennsylvanian, West Virginia: Regrer and Teets, 778.

Connellsville sandstone, Pennsylvanian, West Virginia : Reger and Teets, 778.

Connellsville (Iower) sandstone, Pennsylvanian, West Virginia: Reger and Teets, 778 .

Connoquenessing (Lower) sandstone, Pennsylvanian, West Virginia: Reger and Teets, 778.

Connoquenessing (Upper) sandstone, Pennsylvantan, West Virginia: Reger and Teets, 778 .

Conococheague limestone, Cambrian, Maryland : Clark et al., 179.
Cook Mountain formation, Tertiary, Texas : Matteson, 634.

Coon Mountain bed, Carboniferous, Texas : Drake, 266.

Cooper limestone, Devonian, Missouri : Branson, 102.

Corral Hollow shales, Mesozoic, California : Davis, 230.

Cotton limestone, Carboniferous, oklahoma : Bowen, 91 ; Cullen, 213.

Cottonwood limestone member, Permian, Kansas: Moore and Haynes, 697.

Cottonwood Creek bed, Carboniferous, Texas: Drake, 266.

Council Grove formation, Permian, Kansas: Moore and Haynes, 697.

Covada group, Carboniferous(?), Washington: Pardee, 741.

Craghead Creek shale, Devonjan, Missouri Brauson, 102.

Crouse limestone, Carboniferous, Oklahoma : Bowen, 91; Cullen, 213.

Cypress sandstone, Mississippian, Illinois and Kentucky : Ulrich, 962.

Cypress sandistone, Mississippian, Missouri : Branson, 102.

Cypress ("Big Clifty") sandstone, Mississippian, Kentucky and Illinois: Butts, 140.

Cypress Hills beds; Oligocene, Saskatchewan: Davis, 233.

Cyrene limestone, Silurian, Missouri : Branson, 102.

Dakota formation, Cretaceous, Utah : Dake, 219.

Dakota sandstone, Cretaceous, Colorado, New Mexico : Lee, 554.

Dakota sandstone, Cretaceous, Colorado: Ziegler, 1091.

Dakota sandstone, Cretaceous, Kansas: Moore and Haynes, 697 ; Perrine, 751.

Dakota sandstone, Cretaceous, South Dakota : Darton, 228.

Dakota sandstone, Cretaceous, Utah : Emery, 288.

Darby formation, Devonian, Wyoming: Blackwelder, 76.

Davis member, Cambrian, Missouri : Branson, 102 ; Tarr, 932.

Day Creek dolomite member, Permian, Kansas: Moore and Haynes, 697.

Dealwood formation, Cambrian, South Dakota : Darton, 228.

Decaturville chert, Devonian, Tennessee : Dunbar, 273.

Decew member of Lockport, Sllurian, New York: Chatlwick, 158.

Decota sandstone, Pennsylvanian, West Virginia : Reger and Teets, 778 .

Deep Spring formation, pre-Cambrian, California : Kirk, 519

Deer Creek limestone, Carboniferous, Oklahoma: Bowen, 90; Fenld and Mather, 425.

Deer Creek limestone member, Pennsylvanian, Kansas: Moore and Haynes, 697. 
Deerwood iron-bearing member, pre-Cambrian, Minnesota: Harder and Johnston, 403.

Denison formation, Cretaceous, Texas: Stephenson, 909.

Denton clay member, Cretaceous, Texas: Stephenson, 909.

Del Rio clay, Cretaceous, Texas : Roberts, 794.

De Queen limestone member, Cretaceous, Arkansas: Miser and Purdue, 679, 680.

Derby formation, Cambrian, Missouri : Tarr, 932.

Derby member, Cambrian, Missouri : Branson, 102.

Des Moines group, Pennsylvanian, Kansas: Moore and Haynes, 697.

Des Moines group, Pennsylvanian, Missouri : Branson, 102.

Devils Den limestone, Carboniferous, Texas: Böse, 85.

Devils Island. sandstone, pre-Cambrian, Minnesota : Harder and Johnston, 403.

Devil's River limestone, Cretaceous, Texas: Roberts, 794.

Dewey limestone, Carboniferous, Oklahoma : Cullen, 213; Lloyd and Mather, 579.

Dewey limestone, Pennsylvanian, Oklahoma : Greene, 363.

Dewitt formation, Tertiary, Texas: Matteson, 634.

- 9 . .

Diamond Peak quartzite, Pennsylvanian : Kirk, 519.

Dierks limestone lentil, Cretaceous, Arkansas: Miser and Purdue, 679, 680.

Dimple formation, Pennsylvanian, Texas: Baker and Bowman, 32.

Dinwoody formation, Permian or lower Triassic, Wyoming: Blackwelder, 76.

Dinwoody formation, Triassic, Wyoming: Condit, 202.

Doerun member, Cambrian, Missouri : Branson, 102.

Dog Creek dolomite member, Permian, Oklahoma : Aurin, 27.

Dog Creek shale member, Permian, Kansas: Moore and Haynes, 697.

Dog Creek shale member, Permian, Oklahoma : Aurin, 27.

Dolores formation, Triassic, Utah: Dake, 219.

Donnelly iron ore, Silurian, New York : Chadwick, 158.

Dorwin sandstone member, Carboniferous, Wyoming: Blackwelder, 76.

Dotham series, Jurassic, Oregon: Davis, 230.

Double Mountain stage, Permian, Texas : Beede and Waite, 59.

Douglas formation, Pennsylvanian, Kansas: Moore and Haynes, 697.

Douglas formation, Pennsylvanian, Missouri : Branson, 102.

Doyle shale member, Permian, Kansas : Moore and Haynes, 697.

Drum limestone, Pennsylvanian, Missouri : McCourt, 606; Wilson, 1057.
Drum limestone mémber, Pennsylvanian, Kansas : Moore and Haynes, 697.

Duck Creek formation, Crétaceous, Texas: Stephenson, 909.

Duluth gabbro, pre-Cambrian, Minnesota: Harder and Johnston, 403.

Duncan series;'-pre-Carboniferous, British Columbia : Bancroft, 38.

Dunkard formation, Permiáf; Maryland : Clark et al., 179.

Dunvegan formation, Cretaceous, Alberta: McLearn, 610.

Eagle limestone and shale, Pennsylvanian, West Virginia : Reger and Teets, 778 .

Eagle sandstone, Cretaceous, Montana: Bowen, 92 ; Hancock, 395.

Eagle (?) sandstone, Cretaceous, Montana : Collier, 200.

Eagle Creek formation, Eocene, Washington and Oregon: Chaney, 166.

Eagle Ford clay, Cretaceous, Texas and Oklahoma : Stephenson, 909.

Eagle Ford formation, Cretaceous, Texas: Roberts, 794.

East Lynn sandstone, Pennsylvanian, West Virginia: Reger and Teets; 778.

Ector tongue, Cretaceous, Texas: Stephenson, 909.

Edgewood formation, Silurian, Missouri : Branson, 102.

Edmonton formation, Cretaiceous, Alberta : Allan, 12.

Eileen sandstone, pre-Cambrian, Minnesota : Harder and Johnston, 403.

Elbrook limestone, Cambrian, Maryland: Clark et al., 179.

Elgin sandstone, Pennsylvanian, Kansas: Moore and Haynes, 697.

Elgin sandstone, Pennsylvanian, Oklahoma: Greene, 363.

Elk conglomerates, Cretaceous, British Columbia : Rose, 806. 'i) 1

Elk Lick limestone, Pennsylvanian, West Virginia : Reger and Teets, 778.

Ellenburger. formation, pre-Carboniferous, Texas: Kempher, 504.

Elliott Creek bed, Carboniferous, Texas ; Drake, 266.

Ellis formation, Jurassic, Montana : Cal liẹr, 200 ; Condit, 202 ; Pardee, 738; Stebinger, 915.

Elm Creek bed, Carboniferous, Texas: Drake, 266.

Elm Creek limestone, Carboniferous, Tex as : Böse, 85 .

Elmdale shale member, Pennsylvanian, Kansas: Moore and Haynes, 697.

Elvins formation, Cambrian, Missouri: Branson, 102 ; Tarr, 932.

Eminence chert, Cambrian, Missourl : Tarr, 932.

Eminence formation, Ozarkian, Missouri : Branson, 102.

Emporia limestone member, Pennsylvanian, Kansas: Moore and Haynes, 697,

Englewood limestone, Carboniferous, South Dakota : Darton, 228.

.


Tnid. formation, Permian, Kansas : Moore and Faynes, 697.

Finid formation, Permian, Oklahoma : Aurin, 27.

Enterprise shale member, Permian, Kansas: Moore and Haynes, 697.

Erwin quartzite, Cambrian, Virginia : Hewett et al., 433.

Escamela limęstones, Cretaceous, Mexico: Dumble, 271.

Eskridge shale member, Pennsylvanian, Kansas: Moore and Flaynes, 697.

Estevan beds,' Eocene, Saskatchewan : Davis, 233.

Etchegoin formation, Mlocene, California : English, 294.

Nutaw sand, Cretaceous, Alabama: Hager, 387.

Evanston formation-(?), Cretaceous, Wyoming: Schultz, 833.

Fabre series, pre-Cambrian, Quebec: Wilson, 1058.

Ferguson gypsum member, Permian, Oklahoma: Aurin, 27.

Fern Glen formation, Mississippian, Missouri : Branson, 102.

Fernie formation, Jurassic, British Columbia : Rose, 806 .

liernvale formation, Ordoviciau, Missouri : Brauson, 102.

Ferris formation, Tertlary (?) Wyoming: Bowen, 88.

Fibori limestone, Stlurian, Michlgan : Savage and Crooks, 818.

Fitzgerald limestones, Silurian, Northwest Territory : Cameron, 146.

Flat Gap member, Devonian, Tennessee : Dunbar, 273.

Flathead beds, Cretaceous, British Columbia: Rose, 806.

Flathead quartzite, Cambrian, Montana : Blackwelder, 76; Pardee; 738.

Flathead quartzite, Cambrian, Wyoming: Schultz, 833.

Flaxville gravel, Miocene or Pliocene, Mon- tana: Collier and Thom, 201.

Flaxville gravel, Tertiary, Montana: Collier, 200.

Fleming clay, Tertiary, Gulf coast : Matte- son, 634.

Florence flint member, Permian, Kansas: Moole and Haynes, 697.

Flowerpot shale member, Permian, Kansas: Moore and Haynes, 697.

Foraker limestone, Carboniferous, Oklahoma : Bowen, 91; Cullen, 21.3; Heald, 423.

Forest Hill sand, Tertiary, Mississippi : Cooke, 205.

Fort Hays limestone member, Cretaceous, Kansas: Moore and Haynes, 697.

Fort Payne ("Tullahoma") chert, Mississippian, Kentucky and Illinois:- Butts, 140.

Fort Riley limestone, Oklahoma: Cullen, 213.
Fort Riley limestone member, Permiān; Kansas: Moore and Haynes, 697.

Fort Scott formation, Pennsylvanian, Kansas and Oklahoma: Berger, 64.

Fort Scott limestone, Pennsylvanian, Missouri: MeCourt, 606.

Fort Scott limestone member, Pennsylvilnian, Kansas: Moore and Haynes, 697.

Fort Union formation, Eocene, North Dakota: Quirke, 772.

Fort Union formation, Eocene (?) North Dakota : Collier, 199.

Fort Union formation, Eocene, Saskatchewan : Davis, 233.

Fort Union formation, Eocene, Wyoming: Wegemann, 1010.

Fort Union formation, Tertiary, Montana : Collier, 200.

Fort Worth limestone, Cretaceous, Texas : Shuler, 864; Stephenson, 909.

Fourmile sandstone, Pennsylvanian, Oklahoma : Bowen, 89.

Fox Ford bed, Carboniferous, Texas : Drake, 266.

Fox Hills formation, Cretaceous, Saskatchewan : Davis, 233.

Franciscan formation, Jurassic (?), California : English, 294.

Franciscan group, Mesozolc, Callfornit : Davis, 230, 232. is

Franklin limestone, pre-Cambrian, Pennsylvania : Jonas, 485.

Franks conglomerate, Oklahoma: Cullen, 2.13.

Freda sandstone, pre-Cambrian, Minnesota : Harder and Johnston, 403.

Fredericksburg group, Cretaceous, Texas and Oklahoma: Stephenson, 909.

Fredericksburg limestone, Cretaceous, Texas: Drake, 266.

Fredonia oolite member, Mississippian, Kentucky and Illinois: Butts, 140; Ulrich, 962 .

Freeport (Lower) limestone, Pennsylvanian. West Virginia: Reger and Teets, 778.

Freeport (Lower) sandstone, Penusylvanian, West Virginia: Reger and Teets, 778.

Freeport (Upper) limestone, Penuusylvanian, West Virginia: Reger and r'eets, 778.

Freeport (Upper) sandstone, Penusylvanian, West Virginia: Reger and Teets. 778.

Frontier formation, Cretaceous, Wyomlug: Bowen, 88; Moody and Tiliaferro, 688.

Frontier formation, Cretaceous, Wyoming and Idaho: Schultz, 8:3i.

I'ulton green shale, Penusylvanian, West Virginia: Reger and Teets, 778 .

Furnaceville iron ore, Sllurian, New York: Chadwick, 158.

Fuson shale, Cretaceons, South Makot: : Darton, 228.

Galena' dolomite, Ordovician, "Wisconsin : Alden, 8. 
Galesburg shale, Pennsylvanian, Missouri : McCourt, 606 ; Wilson, 1057.

Galesburg shale member, Pennsylvanian, Kansas: Moore and Haynes, 697.

Galice series, Jurassic, Oregon : Davis, 230.

Gallatin limestone, Cambrian, Wyoming and Idaho: Schultz, 833.

Gallatin limestone, Cambrian, Wyoming and Montana: Blackwelder, 76.

Gaptank formation, Pennsylvanian, Texas : Udden, 959.

Garibaldi volcanic formation, Pleistocene, British Columbia: Burwash, 135.

Garrison limestone and shale member, Permian, Kansas : Moore and Haynes, 697.

Gasconade formation, Ordovician, Missourl : Tarr, 932.

Gasconade formation, Ozarkian, Missourl : Branson, 102.

Gasper oolite, Mississippian, Kentucky : Butts, 140 ; Ulrich, 962.

Gates limestone, Silurian, New York : Chadwick, 158.

Gatesburg formation, Ozarkian, Pennsylvania: Butts, 142.

Genesee member, Devonian, Maryland : Clark et al., 179.

Genesee shale, Devonian, New York: Grabau, 355 .

Giants Range granite, pre-Cambrian, Minnesota: Harder and Johnston, 403.

Gilbert (Upper) sandstone, Pennsylvanian, West Virginia : Reger and Teets, 778.

Gilboy sandstone, Pennsylvanian, West Virginia: Reger and Teets, 778 .

Gilliam formation, Permian, Texas: Udden, 959 .

Girardeau limestone, Silurian, Missouri : Branson, 102.

Gladeville sandstone, Pennsylvanian, Virginia : Hinds, 439.

Glen Dean limestone, Mississippian, Kentucky and Illinois: Butts, 140; Ulrich, 952.

Glendon limestone member, Tertiary, Alabama and Mississippi : Cooke, 205.

Glen Park limestone, Mississippian, Missouri : Branson, 102.

Glenrose beds, Cretaceous, Texas : Böse, 85 .

Golconda formation, Mississippian, Kentucky and Illinois: Butts, 140; Ulrich, 962.

Golconda shale, Mississippian, Illinois and Kentucky : Ulrich, 962.

Goodland limestone, Cretaceous, Texas and Oklahoma : Stephenson, 909.

Goodland limestone, Oklahoma: Cullen, 213.

Gosport greensand, Tertiary, Alabama : IIager, 387.

Grafton sandstone, Pennsylvanian, West Virginia: Reger and Teets, 778.

Grand Falls chert, Mississippian, Oklahoma: Perry, 752.

Grand Gulf formation, Tertiary, Alabama: Irạger, 387.
Grand Tower limestone, Devonian, Missouri : Branson, 102.

Graneros shąle, Cretaceous, Colorado: Ziegler, 1091.

Graneros shale, Cretaceous, South Dakota: Darton, 228.

Graneros shale member, Cretaceous, Kansas: Moore and Haynes, 697.

Grape Creek bed, Carboniferous, Texas : Drake, 266.

Grape Creek formation, Permian, Texas: Beede and Waite, 59.

Grassy Creek shale, Mississippian, Missouri : Branson, 102.

Gravina series, Triassic, Alaska: Chapin, 167.

Grayhorse limestone, Carboniferous, Oklahoma: Bowen, 91.

Grayson marl member, Cretaceous, Texas : Stephenson, 909.

Great Smoky formation, Georgia: Shearer and Húll, 859.

Greenbrier formation, Mississippian, Maryland: Clark et al., 179.

Greenbrier limestone, Mississippian, West Virginia : Reger and Teets, 778 .

Greenhorn limestone, Cretaceous, Colorado: Ziegler, 1091.

Greenhorn limestone, Cretaçeous, South Dakota: Darton, 228.

Greenhorn limestone member, Cretaceous, Kansas: Moore and Haynes, 697.

Green River formation, Tertiary, Colorado: Ziegler, 1091.

Green River formation, Tertiary, Utah : Winchester, 1066.

Greer formation, Permian, Kansas : Moore and Haynes, 697.

Greer formation, Permian, Oklahoma : Aurin, 27.

Grimsby (Medina) sandstone, Silurian, New York: Chadwick, 158.1

Grizzly Bear formation, Cretaceous, Alberta: Allan, 12 ; Slipper, 871.

Gros Ventre formation, Cambrian, Wyoming: Blackwelder, 76; Schultz, 833.

Gulf series, Cretaceous, Texas and Oklahoma: Stephenson, 909.

Guyandot sandstone, Pennsylvanian, West Virginia : Reger and Teets, 778.

Hackberry shale member, Permian, Kansas: Moore and Haynes, 697.

Hamilton formation, Devonian, Pennsylvania: Butts, 142.

Hamilton member, Devonian, Maryland : Clark et al., 179.

Hampshire formation, Devonian, Maryland : Clark et al., 179.

Hampton shale, Cambrian, Virginia: Hewett et al., 433.

Hanna formation, Tertiary, Wyoming: Bowen, 88.

Hanna Valley bed, Carboniferous, Texas: Drake, 266.

Hannibal shales, Mississippian, Missouri : Branson, 102. 
Hardin sandstone member, Devonian, Tennessee: Dunbar, 273.

Hardinsbuirg sandstone, Mississippian, Illinois and Kentucky: Butts, 140; Ulrich, 962.

Harper sandstone member, Permian; Kansas: Moore and Haýnes, 697.

Harpers formation, Cambrian, Marŷland : Clark et'al., 179.

Harrell shale, Devonlan, Pennsylvanla : Butts, 142.

Harriman novaculite, Dévonian, Tennessee: Dunbar, 273.

Hartridge black shale, Pennsylvanian, West Virginia: Reger and Teets, 778.

Harvey conglomerate, Pennsylvanian, West Virginia: Reger and Teèts, 778.

Hasmark formation, Cambrian, Montana : Pardee, 738.

Hatchitigbee formation, Tertiary, Alabama: Hager, 387.

Haymond formation, Pennsylvanian, Texas: Baker and Bowman, 32.

Hay River limestones, Devonian, Northwest Territory : Cameron, 146.

Hay River shales, Devonian, Northwest Territory : Cameron, 146.

Haystack gypsum member,' Permiain, Oklahoma : Áurin, 27.

Helderberg formation, Devonlan, Maryland : Clark et al., 179.

Eelderberg limestone, Devonian, Pennsylvania: Butts, 142.

Fendricks dolomite, Silurian, Michigan : Savage and Crooks, 818.

Henrletta formation, Pennsylvanian, Missouri: Branson, 102; McCourt, 606; Wilson, 1057.

Henshaw formation, Pennsylvanian, Kentucky: Lee, $\mathbf{5 5 2}$.

Herkimer sandstone, Silurian, New York: Chadwick, 15.8.

Ferrington,' limestone, Oklahoma : Cullen, 213.

Herrington limestone member, Permian, Kansas: Moore and Haynes, 697.

Hertha limestone, Pennsylvanian, Missouri : McCourt, 606; Wilson, 1057.

Hertha limestone member, Fennsylvanian, Kansas: Moore and Haynes, 697.

Hess formation, Permian, Texas: Udden, 959.

Hilliard formation (?), Cretaceous, $W y$. oming : Schultz, 833.

Hog Creek bed, Carboniferous, Texns: Drake, 266.

Hogshooter limestone, Carboniferous, Oklahoma : Cullen, 213; Lloyd and Mather, 579 ; Ross, 91.

Holston marble, Ordovician, Tennessee: Stose and Schrader, 923.

Holtsclaw sandstone, Mississippian, Kentucky and Indiana: Butts, 140.

Home Creek bed, Carboniferous, Texas: Drake, 266.

Homewood sandstone, Pennsylvanian, West Virginia : Reger and Teets, $\mathbf{7 7 8}$.
Hordes Creek bed, Carboniferous, Texas: Drake, 266.

Horse Creek bed, Carboniferous, Texas: Drake, 266.

Horse Creek clays and shales, Carboniferous, Texas : Drake, 266.

Horsethief sandstone, Cretaceous, Montana: Stebinger, 915.

Howard limestone member, Pennsylvanian, Kansas: Moore and Haynes, 697.

Iatan limestone member, Pennsylvanian, Kansas: Moore and Haynes, 697.

Illinoian drift, Pleistocene, Wisconsin : Alden, 8.

Indian Creek bed, Carboniferous, Texas: Drake, 266.

Ingleside chert, Mesozolc, California : Davis, 230.

Iola limestone, Pennsylvanlan, Missour1: McCourt, 606; Wilson, 1057.

Iola limestone member, Pennsylvanian, Kansas: Moore and Haynes, 697.

Iowan drift, Pleistocene, Wisconsin : Alden, 8.

Irondequoit limestone, Sulurian, New York : Chadwick, 158.

Jacalitos formation, Miocene, California : English, 294.

Jackson formation, Tertlary, Alabama and Mississippi : Cooke, 205.

Jackson formation, Tertiary, Gulf const: Matteson, 634.

Jagger Bend bed, Carboniferous, Texas: Drake, 266.

Jane Lew sandstone, Pennsylvanian, West Virginia : Reger and Teets, 778.

Jefferson limestone, Devonian, Montana : Pardee, 738.

Jefferson limestone, Devonian, Wyoming : Schultz, 833.

Jefferson City formation, Ordovician, Missouri : Branson, 102 ; Tarr, 932.

Jenkins shale member, Permian, Kansas: Moore and Haynes, 697.

Jennings formation, Devonian, Maryland : Clark et al., 179.

Joachim formation, Ordovician, Missouri : Branson, 102.

Johnstown cement limestone, Pennsylvanian, West Virginia: Reger and Teets, 778.

Judith River formation, Cretaceous, Montaria: Bowen, 92; Collier, 200; Hancock, 395.

Juniata formation, Ordovician, Maryland : Clark et al., 179.

Juniata formation, Sllurian, Pennsylvania: Butts, 142.

Kaibab limestone, Carboniferous, Arizona : Schuchert, 828.

Kaminis granite, pre-Cambrian, Manitoba : Bruce, 113.

Kaminis granite, pre-Cambrian, Saskatchewan : Bruce, 111.

Kanawha black flint, Pennsylvanian; West VIrginia : Reger and Teets, 778 . 
Kanawha group, Fennsylranian, West Virginia : Reger and Teets, 778 .

Kansas City formation, Pennsylvanian, Kansas: Moore and Harnes, 697.

Kansas City formation, Pennsylvanian, Missouri : Branson, 102 ; McCourt, 606 ; Wilson, 1057.

Kanwaka shale member, Pennsylvaniau, Kansas: Moore and Haynes, 697.

Kaslo volcanics, Carboniferous, British Columbia: Bancroft, 38.

Keepalloo iron formation, pre-Cambrian, Belcher Islands, Canada: Moore, 693.

Kenwood sandstone, Mississippian, Kentucky and Indiana: Butts, 140.

Keokuk limestone, Mississippian, Missouri : Branson, 102.

Keokuk limestone, Mississippian, Missouri and Iowa : Van Tuyl, 972 .

Ketchikan series, Carbonifelous and Triassic, Alaska: Chapin, 167.

Kiamichi clay, Cretaceous, Texas : Stephenson, 909.

Kiamiehi formation, Oklahoma : Cullen, 213.

Kimmswick limestone, Ordovician, Missouri : Branson, 102.

Kintla formation, pre-Cambrian, British Columbia: Rose, 806.

Kiowa shale, Comanchea fl, Kansas: Moore and Haynes, 697 ; Perribe' 751 .

Kiowa shales, Cretaceous, Kansas: Twenhofel, 956.

Kirker tuffs, Oligocene, California: Clark, 172.

Kirkland formation, Silurian, Pennsylvania and Maryland: Ulrich, 963.

Kirkland iron ore, Silurian, New York: Chadwick, 158.

Kirkland Lake series, pre-Cambrian, Quebec: Wilson, 1058.

Kiser gypsum member, Permian, Oklaloma : Aurin; 27.

Kishenena formation, Tertiary, 'British Columbia : Rose, 806.

Kisseynew gneiss, pre-Cambrian, Saskatchewan: Bruce, 111.

Kisseynew group, pre-Cambrian, Manitoba : Bruce, 113.

Kitanning (Lower) fire clay, Pennsylvanian, West Virginia : Reger and Teets, 778.

Kitanning (Upper) fire clay, Pennsylvanian, West Virginia : Reger and Teets, 778.

Klutina group, Carboniferous or pre-Carboniferous, Alaska : Chapin, 168.

Knife Lake slate, pre-Cambrian, Minnesota: Harder and Johnston, 403.

Knight formation, Tertiars, Wyoming and Idaho: Schultz, 833.

Knox dolomite, Cambro-Ordovician, Georgia : Shearer, 858 .

Knox dolomite, Ordovician, Tennessee : Stose and Scbrader, 923.
Kootenai formation, Cretaceous, Montana: Bowen, 92 ; Condit, 202 ; Hancock, 395 ; Pardee, 738 ; Stebinger, 915.

Kootenai (?) formation, Cretaceous, Montana: Collier, 200.

Kootenay formation, Cretaceous, British Columbia: Rose, 806.

Ĺreyenhagen shale, Oligocene, Cahifornia: Clark, 172.

Labadie: limestone, Carboniferous, Oklahoma: Bowen, 90; Clark, 174.

Labadie limestone, Pennsylvanian, Oklahoma : Winchester et al., 1067.

Labette shale, Pennsylvanian, Missouri : McCourt, 606.

Labette shale, Pennsylvaniai, Oklahoma: Greene, 363.

Labette shale member, Pennsylvanian, Kansas: Mọore and Haynes, 697.

La Cruz marl, Tertiary, West Indies : Vaughan, 979.

Ladore shale, Pennsylvanian, Missouri : MeCourt, 606 ; Wilson, 1057.

Ladore shale member, Pennsylvanian, KanSas : Moore and Haynes, 697.

"Lafayette" formation, Mississippi Valley: Shaw, 850 .

Lafayette formation, Tertiary, Alabama: Hager, 387.

Lafayette gravel, Tertiary, Alabama : Shaw, 855.

Lakeport limestones, Silurian, New York : Chadwick, 158.

Lake Superior sandstone, pre-Cambrian, Minnesota : IIarder and Johnston; 403.

Lakota sandstone, Cretaceous, South Dakota : Darton, 228.

Lamotto sandstone, Cambrian, Missouri : Branson, 102.

Lance formation, Eocene, North Dakota : Collier, 199.

Lance formation, Tertiary (?), Montana : Bowen, 92 ; Collier, 200; Hancock, 395.

Lance formation, Tertiary (?), Wyoming: Wegemann, 1010.

Lane shale, Pennsylvanian, Missourt: McCourt, 606.

Lane shale member, Pennsylvanian, Kansas: Moore and Haynes, 697.

Lansing formation, Pennsylvanian, Kansas: Moore and Haynes, 697.

Lansing formation, Pennsylvanian, Missouri: Branson, 102 ; McCourt, 606.

La Plata group, Jurassic, Utah : Emery, 288.

Ia Plati sanistone, Jurassic, Utah : Dake, 219.

"Taramie" formation. Cretaceous, Colorado, New Mexico: .Lee, 554

Lardeau diabase schists, post-Carboniferous (?), British Columbia: Bancroft, 38.

Iarder Lake series, pre-Cambrian, Quebec: Wilson, 1058.

Larke dolomite, Ozarkian, Penusylvania : Butts, 142. 
Las Cahobes beds, Tertiary, Haiti : Jones, 490.

Lawrence shale member, Pennsylvanián, Kansas: Moore and Haynes, 697.

Lea Park formation, Cretaceous, Alberta : Allan, 12 ; Slipper, 871 .

Lecompton limestone, Carboniferous, Oklahoma: Bowen, 90; Clark, 174; Héáld and Mather, 425.

Lecompton limestone member, Pennsylvanian, Kansas: Moore 'and Haynes, 697.

Lee formation, Pennsylvanian, Virginia: Hinds, 439.

Leigh dolomite member, Ordovician, Wyoming: Blackwelder, 76.

Lemont limestone member, Ordovician, Pennsylvania: Butts, 142.

Lenapah limestone, Oklahoma : Cullen, 213.

Lennep sandstone, Cretaceous, Montana : Hancock, 395.

Lenotr limestone, Ordovician, Tennessee : Stose and Schrader, 923.

Leonard formation, Permián, Texas: Udden, 959.

Lewis shale, Cretaceous;' Colorado, New Mexico: Lee, $\mathbf{5 5 4 .}$

Lewis shale, 'Cretaceous, Wyoming : Bowen, 8s; Wegemann, 1010.

Lincolnville chert, Mississippian, Oklahoma: Perry, 752.

Linden or Helderbergian group, Devonian, Tennessee: Dunbar, 273.

Lisbon formation, Tertiary, Alabama : Hager, 387

Lissie gravel, Tertiary, Alabama: Shaw, 855.

Lissie gravel or Lafayette, Tertiary, Gulf coast: Matteson, 634 .

Little Hominy limestone, Carboniferous, Oklahoma: Heald and Mather, 425.

Lohn bed, Carboniferous, Texas: Drake, 266.

Ioon River formation, Cretaceous, Alberta : McLearn, 610.

Loon River shales, Cretaceous, Northwest Territory : Cameron, 146.

Lost City limestone, Pennsylvanian, Oklahoma : Greene, 363.

Lost: Creek bed, Carboniferous, Texas: Drake, 266.

Loudon formation, Cambrian, Maryland : Clark et al., 179.

Louisiana limestone, Mississippian, Missouri: Branson, 1.02.

Lowville limestone, Ordovician, Pennsylvania: Butts, 142

Loxley terrace deposits, Mississippi Valley : Shaw, 850 .

Lucero beds, Cretaceous, Cuba: DeGolyer, 241.

Iueders formation, Permian, Texas : Beede and Waite, 59.

Iuta limestone member, Permian, Kansas: Moore and Haynes, 697.

Luyano marls, Cretaceous, Cuba: De Golyer, 241.
Lynch Creek bed, Carboniferous, Texas: Drake, 266.

McAdám formation, Silurian, Nova Scotia : McLearn, 611.

McBean formation, Eocene, Georgia : Cooke and Shearer, 206.

McCarthy shale, Triassic, Alaska : Moffit, 683.

McElmo formation, Cretaceous (?); Utah : Emery, 288.

McElmo formation, Jurassic, Utah: Dake, 219.

McKenzle formation, Silurian, Maryland : Clark et al., 179.

McKenzie limestone, Silurian, Pennsylvania: Butts, 142.

McLeansboro formation, Pennsylvanian, Kentucky : Lee, 552.

Madison limestone, Carboniferous, Monr tana : Collier, 200 ; Pardee, 738.

Madison limestone, Carboniferous, Wyoming, Blackwelder, 76 .

Madison - limestone, Carboniferous, Wyoming and Idaho: Schultz, 833.

Madison limestone, Mississipplan, Mon, tana : Stebinger, 915.

Madison sandstone, Cambrian, Wisconsin : Alden, 8.

Magnesian (Lower), limestone, Ordovician, Wisconsin : Alden, 8.

Magothy formation, Cretaceous, Maryland : Clark et al., 179 ; Little, 577.

Mahoning sandstone stage, Pennsylvanian, West Virginia: Reger and Teets, 778.

Main Street limestone member, Cretaceous, Texis: Stephenson, 909.

Maissade beds, Tertiary, Haitl: Jones, 490 . Mancos shale, Cretaceous, Colorado, New Mexico : Lee, 554 .

Mancos shale, Cretaceous, Utah: Emery, 288.

Mangum dolomite member, Permian, Oklahoma : Aurin, 27.

Manitoulin shale, Silurian; New York: Chadwick, 158.

Maltrata limestone, Cretaceous, Mexico : Dumble, 271.

Maplewood shale, Silurian; New York: Chadwick, 158.

Maquoketa shale, Ordovician, Missourl: Bronson, 102.

Maquoketa shale, Ordovician, Wisconsin : Alden, 8.

Marathon series, Ordovician, Texas: Baker and Bowman, 32.

Maravillas formation, Ordovician, Texas: Baker and Bowman, 32.

Marble Falls formation, Mississippian, Texas: Kempher, 504.

Marble Falls limestone, Mississippian, T'exas : Hager, 388.

Marcellus member, Devonian, Maryland : Clark et al., 179.

Marcellus shale, Devonian, Pennsyivania: Butts, 142.

Marianna formation, Oligocene, Florida : Sellards and Gunter, $\mathbf{8 4 2}$ 
Marianna limestone, Tertiary, Alabama and Mississippi : Cooke, 205.

Mariin sandstone, Mesozoic, Callfornia : Davis, 230.

Marion formation, Permian, Kansas : Moore and Haynes, 697 ; Perrine, 751.

Markley formation, Oligocene, California : Clark, 172.

Marmaton formation, Pennsylvanian, Kansas: Moore and Haynes, 697.

Marseilles drift, Quaternary, Illinois: Cady, 143.

Marshall Lake series, pre-Cambrian, Ontario: Hopkins, 455.

Martinsburg formation, Ordovician, Maryland: Clark et al., 179.

Martville sandstone, Silurian, New York: Chudwick, 158.

Matawan formation, Cretaceous, Maryland : Clark et al., 179 ; Little, 577.

Matfield shale member, . Permian, Kansas: Moore and Haynes, 697.

Mauch Chunk formation, Mississippian, Maryland: Clark et al., 179.

Mauch Chunk series, Mississippian, West Virginia: Reger and Teets, 778.

Mauch Chunk shale, Mississippian, Pennsylvania: Butts, 142.

Mayville beds, Silurian, Wisconsin: Alden, 8.

Maywood formation, Silurian (?), Montana: Pardee, 738.

Medicine Bow formation, Cretaceous, Wyoming: Bowen, 88.

Medicine Lodge gypsum member, Permian, Kansas: Moore and Haynes, 697.

Medicine Lodge gypsum member; Permian, Oklahoma: Aurin, 27.

Meganos group, Eocene, California : Clark, 171.

Menard limestone, Mississippian, Kentucky and Illinois: Butts, 140 ; Ulrich; 962.

Mendez formation, Cretaceous and Tertiary, Mexico: Dumble, 271.

Mendota limestone, Cambrian, Wisconsin : Alden, 8.

Menteth limestone, Devonian, New York: Grabau, 355.

Mentor beds, Comanchean, Kansas: Perrine, 751.

Mentor beds, Cretaceous, Kansas: Twenhofel, 956.

Meramec group, Mississippian, Kentucky and Illinois: Butts, 140.

Mesilverde formation, Cretaceous, Colorado, New Mexico: Lee, 554.

Mesaverde formation, Cretaceous, Wyoming, Bowen, 88; Moody and Taliaferro; 688 ; Wegemann, 1010.

Meson berls. Tertiary, Mexico: Dumble; 271.

Midway formation, Tertiary, Gulf coast: Matteson, 634.

Midway group, Tertiary, Alabama : Hager, 387.

Milford granite gneiss, pre-Carboniferous; Rhode Island: Hawkins, 412, ;
Milwaukee formation, Devonian, Wisconsin : Alden, 8:

Mines dolomite, Ozarkian, Pentnsylvania : Butts, 142.

Minnekahta limestone, Carboniferous, South Dakota: Darton, 228.

Minnelusa sandstone, Carboniferous, South Dakota: Darton, 228.

Minnewaste limestone, Cretaceus, South Dakota : Dartön, 228.

Mint Spring calcareous marl mémber, Alabama and Mississippi : Cooke, 205.

Missi (Lower) formation, pre-Cambrian, Manitoba: Bruce, 113.

Missi (Lower) series, pre-Cambrian, Saskatchewan: Bruce, 111.

Missi (Upper) formation, pre-Cambrian, Manitoba: Bruce, 113.

Missi (Upper) series, pre-Cambrian, Saskatchewan : Bruce, 111.

Missouri group, Pennsylvanian, Kansas : Moore and Haynes, 697.

Missouri group, Pennsylvanian, Missouri : Branson, 102.

Moenkopi formation, Triassic, Utah: Emery, 288.

Monitor - sandstone, Pennsylranian, West Virginia : Reger and Teets, 778.

Monmouth formation, Cretaceous, Maryland: Clark et al., 179 ; Little, 577.

Monongahela formation (Elkgarden), Pennsylvanian, Maryland: Clark et al., 179.

Monongahela series, Pennsylvanian, West Virginia: Reger and Teets, 778.

Monte Sana group, Mississipplan, Illinols and Kentucky: Ulrich, 962.

Monterey group, California : Davis, 232.

Moodys calcareous marl member, Alabama and Mississippi : Cooke, 205.

Morgantown - sandstone, Pennsylvanian, West Virginia: Reger and Teets, 778.

Morrison formation, Cretaceousl (?), Colorado, New Mexico: Lee, $\mathbf{5 5 4}$.

Morrison formation, Cretaceous, Wyoming : Bowen, 88.

Morrison formation; Cretaceous (?), Wyoming: Wegemann, 1010.

Morrison formation, Jurassic (?), Great Plains: Schuchert, 830.

Morrison formation, Rocky Mountain region: Mook, 691 .

Morrison (?) formation, Cretaceous (?), Montana: Hancock, 395.

Morrison shale, Cretaceous (?), South Dakota: Darton, 228.

Morse Creek limestone, Devonian, New York : Grabau, 355.

Moscow shale, Devonian, New York: Grabatt, 355.

Mt. Marion beds, Devonian, New York: Grabau, 355.

Mt. Selman formation, Tertiary, Gulf coast: Matteson, 634.

Mowry shale, Cretaceous, Montana : Collier, 200.

Mowry shale, Cretaceous, Wyoming: Bowen, 88: Moody and Talinferro, 688 . 
Mowry shale member, Cretacens, Myoming: Wegemann, 1010.

Moydart formation, Silurian, Nova Scotia : McLearn, 611.

Muav limestone, Cambrian, Arizona' Sçhuchert, 829.

Myrtle formation, Cretaceous, Oregon : Smith, 884.

Myrtle Creek formation, Cretaceous, Alberta: Allan, 12.

Naheola formation, Tertiary, Alabama: Hager, 387.

Nanjemoy formation, Tertiary, Maryland : Clark et al., 179 ; Little, 577.

Naknek formation, Jurassic, Alaska : Chapin, 168.

Nanafalia formation, Tertiary, Alabama: Hager, 387.

Navajo sandstone, Jurassic, Utah : Emery, 288.

Navarro formation, Cretaceous, Texas: Stephenson, 909.

Nelson granite, Jurassic, British Columbia : Bancroft; 38.

Neva limestone, Carboniferous, Oklahoma : Bowen, :91; Cullen, 213. . :

Neva limestone, Permian, Kansas: Perrine, 751. \& $C$, ?

Neva limestonè member, Pennsylvanian, Kansas: Moore and Haynes, 697.

Newark formation, Triassic, Maryland: Clark et al., 179.

New Providence shale, Mississippian, Kentucky and-Indiana: Butts, 140.

New Richmond sandstone, Ordovician, Illinois: Cady, 143.

New River group, Pennsylvanian, West Virginia: Reger and Teets, 778.

Newton limestone and shale, Pennsylvanian, West Virginia : Reger and Teets, 778.

Niagara dolomite, Silurian, Wisconsin: Alden, 8. .

Nikomeki sand and silt, Pleistocene, British Columbia: Burwash, 135.

Niobrara formation, Cretaceous, Colorado: Ziegler, 1091.

Niobrara formation, Crètaceous, Kansas: Moore and Haynes, 697.

Niobrara formation, Cretaceous, Colorado, New Mexico: Lee, 554.

Niobrara formation, Cretaceous, South Dakota: Darton, 228.

Niobrara formation, Cretaceous, Wyoming: Bowen, 88; Wegemann, 1010:

Nittany dolomite, Canadian, Pennsylvania : Butts, 142.

Noix oolite, Silurian, Missouri: Branson, 102.

Nonesuch shale; pre-Cambrian, Minnesota : Harder and Johnston, 403.

North Park formation, Tertiary, Wyoming: Bowen, 88.

Northview formation, Mississippian, Missouri: Branson, 102.

Norton formation, Pennsylvanian, Virginia : Filnds, 439.
Nugget sandstone, Jurasslc, Wyoming and Idaho: Schultz, 833.

Nuttall sandstone, 'Pennsylvanian, West Virginia : Reger and Teets, 778.

Nuttall (Lower) sandstone, Pennsylvanián, West Virginia: Reger and Teets, 778.

Oakridge sandstone, Mesozoic, California : Davis, 230.

Ocala formation, Eocene, Florida: Sellards and Gunter, 842 .

Ocala limestone, Eocene, Georgia: Cooke and Shearer, 206.

Ocala limestone, Tertiary, Alabama and Mississippi : Cooke, 205.

Ocoee group, Georgia: Shearer and Hull, 859.

Ogalalla formation, Tertiary, Kansas: Moore and Faynes, 697.

Ogishke conglomerate, pre-Cambrian, Minnesota: Harder and Johnston, 403.

Ohara limestone member, Mississippian, Kentucky : Butts, 140; Ulrich,. 962.

Okaw formation, Mississippian, Missouri : Branson, 102.

Okaw limestone, Mississippian, Illinois: Ulrich, 962.

Okay limestone, Carboniferous, Oklahoma : Heald and Mather, 425 .

Okesa sandstone, Carboniferous, Oklahoma : Clark, 174 ; Hopkins, 454.

Olive Hill formation, Devonian, Tennessee : Dunbar, 273.

Oneota formation, Ordovician; Illinols: Cady, 143.

Onondaga formation, Devonian; Pennsylvania: Butts, 142.

Opeche formation, Carboniferous, South Dakota : Darton, 228.

Oread limestone, Carboniferous, Oklahoma : Bowen, 90 ; Clark, 174 ; Cullen, 213.

Oread limestone, Pennsylvanian, Oklahoma : Heald, 424.

Oread limestone member, Pennsylvanian, Kansas: Moore and Haynes, 697.

Ore Hill limestone member, Ozarklan, Pennsylvania: Butts, 142.

Orienta sandstone, pre-Cambrian, Minnesota: Harder and Johnston, 403.

Oriskany formation, Devonian, Maryland : Clark et al., 179.

Oriskany group, Devonian, Tennessee : Dunbar, 273.

Orizaba limestone, Cretaceous, Mexico: Dumible, 271.

Orlando limestone, Pennsylvanian, West Virginia : Reger and Teets, 778.

Oronto group, pre-Cambrian, Minnesota: Harder and Johnston, 403.

Osage group; Mississippian, Kentucky, Indiana, and Illinois: Butts 140.

Oswego sandstone, Silurlan, Pennsylvania: Butts, 142.

Ottosee shale. Ordovician, 'Tennessee: Stose and Schrader, 923.

Otsquago sandstone, Sllurian, New' York: Chadwick, 158. 
Outer conglomerate, pre-Cambrian, Minnesota: Harder and Johnston, 403.

Owenyo limestone, Permian : Kirk, 519.

Ozuluama series, Tertiary, Mexico : Dumble, 271.

Pahasapa limestone, Carboniferous, South Dakota: Darton, 228.

Paint Creek formation, Mississippian, Illinois : Ulrich, 962.

Paint Rock bed, Carboniferous, Texas: Drake, 266.

Paintrock formation, Permian, Texas : Beede and Waite, 59.

Pakan formation, Cretaceous, Alberta: Allan, 12.

Palestine sandstone, Mississippian, Kentucky and Illinois: Butts, $140 \%$ Ulrich, 962.

Paluxy sands, Cretaceous, Texas: Drake, 266.

Pamunkey group, Tertiary, Maryland : Clark et al., 179.

Papagallos shales, Cretaceous, Mexico: Dumble, 271.

Park City formation, Carboniferous, Utab and Wyoming: Blackwelder, 76.

Park City formation, Carboniferous, Wyoming: Condit, 202.

Park City formation, Pennsylvanian and Permian, Utah: Schultz, 834.

Parkman sandstone member, Cretaceous, Wyoming: Wegemann, 1010.

Parks Mountain bed, Carboniferous, Texas: Drake, 266.

Paso Robles formation, Pliocene, California : English, 294.

Paspotansa member, Tertiary, Maryland : Little, 577.

Patapsco formation, Cretaceous, Maryland : Clark et al., 179; Little, 577.

Patuxent formation, Cretaceous, Maryland : Clarke et àl., 179 ; Little, 577.

Pawhuska limestone, Pennsylvanian, Oklahoma: Heald, 424.

Pawnee limestone, Oklahoma: Cullen, 213.

Pawnee limestone, Pennsylvanian, Missouri : McCourt, 606.

Tawnee limestone member, Pennsylvanian, Kansas: Moore and Haynes, 697.

Pawpaw sandy member, Cretaceous, Texas : Stephenson, 909.

Peace River formation, Cretaceous, Alberta : McLearn, 610.

Peachbottom slate, Ordovician (?), Maryland: Clark et al., 179.

Pearl shale member. Permian, Kansas: Moore and Haynes, 697.

Pecan Gap chalk member, Cretaceous, Texas: Stephenson, 909.

Pegram limestone, Devonian, Tennessee: Dunbar, 273.

Pennington shale, Mississippian, Virginia : Hinds; 439 .

Phoenix or Schroeppel shale, Silurian, New York: Chadwick, 158.

Phosphoria formation, Carboniferous, Wyoming and Idaho Schultz, 833.
Phosphoria formation, Carboniferous and Triassic ( ?), Montana : Condit, 202.

Pierre formation, Cretaceous, Saskatchewan: Davis, 233 .

Pierre shale, Cretaceous, Alberta : Slipper, 871.

Pierre shale, Cretaceous, Colorado: Ziegler, 1091.

Pierre shale, Cretaceous, Kansas: Mooro and Haynes, 697.

Pierre shale, Cretaceous, Colorado, New Mexico: Lee, 554.

Pierre shale, Cretaceous, North Dakota: Collier, 199.

Pierre shale, Cretaceous,' South Dakota : Darton, 228.

Pierson limestone, Mississippian, Missouri : Branson, 102.

Pike gravel member, Cretaceous, Arkansas: Miser and Purdue, 679, 680.

Pine Creek limestone, Pennsylvanian, West Virginia : Reger and Teets, $\mathbf{7 7 8 .}$

Pine Point limestone, Devonian, Northwest Territory : Cameron, 146.

Pine Ridge sandstone, Devonian, Pennsylvania: Butts, 142.

Piscataway member, Tertiary, Maryland : Little, 577.

Pitkin limestone, Oklahoma: Cullen, 213.

Pittsburgh (Lower) sandstone, Pennsylvanian, West Virginia : Reger and Teets, 778.

Pittsburgh red shale, Pennsylvanian, West Virginia : Reger and Teets, 778.

Platteville-Galena dolomite, Ordovician, Illinois : Cady, 143.

Plattin formation, Ordovician, Missouri : Branson, 102.

Plattsburg limestone, Pennsylvanian, Missouri : McCourt, 606.

Plattsburg limestone member, Pennsylvanian, Kansas: Moore and Haynes, 697.

Pleasant Hill limestone, Cảmbrian, Pennsylvania: Butts, 142.

Pleasanton formation, Pennsylvania, Missouri : Branson, 102 ; McCourt, 606.

Pleasanton shale, Pennsylvanian, Missouri : Wilson, 1057.

Pleasanton shale member, Pennsylvanian, Kansas: Moore and Haynes, 697.

Plum Creek bed, Mississippian, Illinois and Kentucky : Ulrich, 962.

Plummer limestone, Carboniferous, Oklahoma : Bowen, 90; Clark, 174.

Pocono formation, Mississippian, Maryland : Clark et al., 179.

Pocono formation, Mississippian, Pennsylvania: Butts, 142.

Pocono sandstone series, Mississippian, West Virginial : Reger and Teets, 778.

Poison Canyon formation, Eocene, Colorado, New Mexico: Lee, 554.

Pokegama quartzite, pre-Cãmbrian, Minnesota : Harder and Johnston, 403.

Pontiac series, pre-Cambrian, Quebec: Wilson, 1058.

Portage member, Devonian, Maryland : Clark et al., 179.

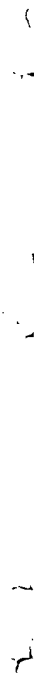


Potapaco member, Tertiary, Maryland: Little, 577.

Potomac group, Cretaceous, Marylannd : Clark et al., 179 ; Little, 577.

Potosi formation, Cambrian, Missouri : Tarr, 932.

Potosi formation, Oźárkian, Missouri : Branson, 102.

Pottsville fórmation, Carboniferous, 'fillinois : Cady, 143.

Pottsville formation, Mississippian, Pennsylvania: Butts, 142.

Pottsville formation, Pennsylvanian, Maryland: Clark et al., 179.

Pottsville group, Pennsylvanian, Kentucky : Butts, 140 ; Lee, 552.

Pottsville series, Pennsylvánian, West Virginia : Reger and Teets, $\mathbf{7 7 8}$.

Prairie du Chien group, Ordovician, Illinois : Cady, 143.

Presquile dolomites, Devonian, Northwest Territory : Cameron, 146.

Proctor formation, Cambrian, Missouri : Tarr, 932.

Proctor formation, Ozarkian, Missouri : Branson, 102.

Puckwunge conglomerate, "pre-Cambrian, Minnesota: Harder and Johnston, 403.

Puget series, Eocene, British Columbia : Burwash, 135.'

Purgatoire formation, Cretaceous, Colorado, New Mexico: Lee, 554.

Puyallup erosion-interval, Pleistocene, British Columbia : Burwash, 135.

Pyburn limestone, Devonian, Tennessee: Dunbar, 273.

Quadrant formation, Carboniferous, Montana: Pardee, 738.

Quadrant quartzite, Carboniferous, Montana : Condit, 202.

Quakertown black slate, Pennsylvanian, West Virginiä : Reger and Teets, 778.

Quall limestone, Devonian, Tennessee : Dunbar, 273.

Quartermaster formation, Permian, Oklahoma : Aurin, 27.

Racine beds, Silurian, Wisconsin: Alden, 8.

Raleigh (Upper) sandstone, Pennsylvanian, West Virginia : Reger and Teets, $\mathbf{7 7 8}$.

Rancocas formation, Cretaceous, Maryland: Clark et al., 179.

Raritan formation, Cretaceous, Maryland : Clark et al., 179; Little, 577.

Raton formation, Eocene, Colorado, New Mexico : Lee, 554.

Ravenscrag beds, Eocene, Saskatchewan: Davis, 233.

Raytown limestone, Pennsylvanian, Missouri : McCourt, 606.

Red. Eagle limestone, Carboniferous, Oklahoma: Bowen, 91 ; Cullen, 213.

Red Bluff clay, Tertiary, Alabama and Mississippi : Cooke, 205.

Red Lion formation, Cambrian, Montana : Pardec, 738.
Redstone limestone, Pennsylvanian, West Virginia: Reger and Teets, 778.

Redwall limestone, Carboniferous, Arizona : Schuchert, 828 .

Reed dolomite, pre-Cambrian, भalifornia : Kirk, 519.

Reedsville shale, Ordovician, Pennsylvania : Butts, 142.

Renault formation, Mississippian, Illinois : Ulrich, 962.

Revard sandstone, Carboniferous, Oklahoma : Clark, 174.

Revard sandstone, Pennsylvanian, Oklahoma: Winchester et al., 1067.

Reward conglomerate, Pennsylvanian : Kirk, 519.

Reynales limestone, Silurian, New York : Chadwick, 158.

Ribstone Creek formation, Cretaceous, Alberta : Slipper, 871.

Ricker bed, Carbonfferous, Texas: Drake, 266.

Ridenhower shale, Mississippian, Kentucky and Illinois: Butts, 140 ; Ulrich, 962.

Ridgely sandstone, Devonian, Pennsylvania : Butts, 142.

Ripley formation, Cretaceous, Alabama: Hager, 387.

Rochelle conglomerate, Carboniferous, Texaş: Drake, 266.

Rochester shale, Silurian, New York: Chadwick, 158 .

Rock Creek limestone, Pennsylvanian, Oklaboma : Greene, 363.

Rockhill limestone, Carboniferous, Texas : Böse, 85.

Rockhouse shale, Devonlan, Tennessee: Dunbar, 273.

Rockmart 'slate, Ordovician, Georgla : Shearer, 858.

Rockvale sandstone member, Cretaceous, Colorado, New Mexico: Lee, $\mathbf{5 5 4}$.

"Rockwood formation," Sllurian, Virginia : Hinds, 439.

Rodman limestone, Ordovician, Pennsylvania: Butts, 142.

Rome formation, Cambrian, Georgla : Shearer, 858.

Romney formation, Devonian, Maryland: Clark et al., 179.

Rosewood shale, Mississtppian, Kentucky and Indiana: Butts, 140.

Rosiclare sandstone member, Misslasippian, Kentucky: Butts, 140; Ulrich, 962.

Ross limestone member, Devonian, Tẹnnessee : Dunbar, 273.

Ross Brook formation, Silurian, Nova Scotia : McLearn, 611.

Roubidoux formation, Ordovician, Missouri : Branson, 102 ; Tarr, 932.

Rough Creek bed, Carboniferous, Texas: Drake, 266.

Ruma formation, Mississippian, Illinois : Ulrich, 962.

Saddle Creek bed, Carboniferous, Texas: Drake, 266. 
St. Bartholomew limestone, Tertiary, St. Bartholomew (West Indies): Vaughan, 979.

St. Clair marble, Oklahoma: Cullen, 213.

St. John ormation, Cretaceous, Alberta : McLea. , 610.

St. Lawrence (?) formation, Cambrian, Wisconsin : Alden, 8.

St. Louis limestone, Mississippian, Tentucky and Indiana: Butts, 140.

St. Louis limestone, Mississippian, Missouri : Branson, 102.

st. Louis limestone, Mississippian, Missouri and Iowa: Van Tuyl, 972.

St. Mary formation, Eocene (?), Montana : Stebinger, 915.

St. Mary's formation, Tertiary, Maryland: Clark et al., 179; Little, 577.

St. Maurice formation, Tertiary, Louisiana : Matteson, 634.

St. Peter sandstone, Ordovician, Illinois : Cady, 143.

St. I'eter sandstone, Ordovician, Missouri : Branson, 102.

St. Peter sandstone, Ordovician, Wisconsin : Alden, 8.

St. Stephens limestone, Tertiary, Alabama: Hager, 387.

Ste. Genevieve limestone, Mississippian, Missouri : Branson, 102.

Ste. Genevieve limestone, Mississippian, Kentucky and Indiana: Butts, 140.

Ste. Genevieve limestone. Mississippian, Illinois and Kentucky, Ulrich, 962.

Salem limestone, Mississippian, Missouri : Branson, 102.

Salinas shale, Miocene, California: English, 294.

Salt Plain shale member, Permian, Kansas: Moore and Haynes, 697.

Saltsburg sandstone, Pennsylvanian, West Virginia, Reger and Teets, 778.

Salt Wash sandstone member, Cretaceous, Utah: Emery, 288.

Sample sandstone, Mississippian, Kentucky : Ulrich, 962.

Sample sandstone member, Mississippian, Kentucky: Butts, 140.

San Angelo formation, Permian, Texas : Beede and Waite, 59.

San Felipe formation, Cretaceous, Mexico: Dumble, 271.

San Juan limestones, Cretaceous, Mexico: Dumble, 271 .

San Lor(-nzo formation, Oligocene, California: Clark and Arnold, 173.

San Lorenzo selies, Oligocene, California Clark, 172.

San Luis formation, Mesozoic, California: Davis, 230.

Sin Rafiel, Tertiary, Mexico: Dumble, 271.

Sin Ramon formation, Oligocene, Callfornial: Clark, 172.

San Srbastian shale, Tertiary, Porto Rico: Semmes, 845 .

Santa Anna bed, Carboniferous, Texas: Diake, 266
Santa Anna Branch bed, Carboniferous, 'Texas : Drake, 266.

Santa Margarita formation, Miocene, California : English, 294.

Sardis terrace deposits, Mississippi Valley: Shaw, 850.

Satsop formation, Pleistocene, Oregon: Smith, 884 .

Sauquoit beds, Silurian, New"York : Chadwick, 158.

Sausalito chert, Mesozoic; California : Davis, 230.

Saxton conglomerate member, Devonian, Pennsylvania : Butts, 142.

Schroeppel shale, Silurian, New York: Chadwick, 158.

Scranton shạle member, Pennsylvanian; Kansas; Moore and Haynes, 697.

Selma chalk, Cretaceous, Alabama: Hager, 387.

Setters quartzite, Cambrian (?) Maryland : Clark et al., 179.

Severy shale member, Pennsylvanian, Kansas : Moore and Haynes, 697.

Sevier shale, Ordovician Tennessee: Stose and Schrader, 923 .

Sewickley limestone, Pennsylvanian; West Virginia : Reger and Teets, 778.

Sewickley (Lower) sandstone, Pennsylva: nian, West Virginia: Reger and Teets, 778.

Sewickley (Upper) sandstone, Pennsylvánian, West Virginia: Reger and Teets, 778.

Sexton Creek limestone, Silurian, Missouri : Branson, 102.

Shadrick Mill sandstone, Carboniferous, Texas : Drake, 266.

Shady dolomite; Cambrian, Virginia: Hew ett et al., 433 .

Shakopee dolomite, Ordovlcian, .Illinois : Cardy, 143.

Shandro shales, Cretaceous, Alberta: Allan, 12.

Sharon sandstone, Pennsylvanian, West Virginia: Reger and Teets, 778 .

Shasta series, Cretaceous, California : English, 294.

Shawnee formation, Pennsylvanian, Kansas: Moore and Haynes, $69 \bar{\tau}$.

Shawnee formation, Pennsylvanian, Missouri : Branson, 102.

Shenandoah limestone, Cambro-Ordovician, Maryland : Clark et al.. 17!).

Shimer gypsum member, Fermian, Kansas : Moore and Haynes, 697 .

Shimer gypsum member, Permian, Oklahoma : Aurin, 27.

Shinarump conglomerate, Triassic, Utah : Emery, 288.

Short Creek oolite, Mississippiạn, Oklahoma: Perry, 75\%.

Shriver limestone, Devonian, rennsylvania: Butts, 142.

Silver Hill formation Cambrian, Montana: Pardee, 738. 
Silver Peak group, Cambrian, California: Kirk, 519.

Simpson shales, Devonian, Northwest Territory : Cameron, 146.

Sioux quartzite, Algonian, Minnesota : Farder and Johnston, 403.

Slave Point limestones, Jevonian, Northwest Territory : Cameron, 146.

Slocan series, Carboniferous, British Columbia: Pancroft, 38.

Smithwick formation, Mississippinn, Texas : Kempher, 504.

Smithwick shale, Mississippian, Texas: Hager, 388.

Smoky IIill chalk member, Cretaceous, Kansas: Moore and Haynes, 697.

Smoky River formation, Cretaceous, Alberta: McIearn, 610.

Snake River basalt, Tertiary, Wyoming and Idaho: Schultz, 833.

Sobrante sandstone, Miocene, California : Clark, 172.

Sodus shale, Silurian, New York: Chadwick, 158.

Spearfish formation,- Triassic (?), South Dakota : Darton, 228.

Speck Mountain clay bed, Carboniferous, Texas: Drake, 266.

Speck Mountain limestone bed, Carboniferous, Texas; Drake, 266.

Spergen limestone, Mississippian, Missouri and Iowa: Van Tuyl, 972.

Spergen ("Salem") limestone, Mississippian, Kentucky, Illinois, and Indiana : Butts, 140.

spring Creek bed, Carboniferous, Texas : Drake, 266.

Stacy dolomite member, Ozarkian, Pennsylvania: Butts, 142.

Stanton limestone, Oklahoma: Cullen, 213.

Stanton limestone, Pennsylvanian, Oklahoma : Greene, 363.

Stunton limestone member, Pennsylvanian, Kansas: Moore and Haynes, 697.

Stanton (?) limestone, Carboniferous; Oklahoma : Clark, 174

Steele shale, Cretaceous, Wyoming: Bowen, 88 ; Wegemann, 1010.

Sterling granite gneiss, pre-Carboniferous. Rhode Island: Hawkins, 412.

Sterling Station iron ore, Silurian, New York: Chadwick, 158.

Stewartsville group, Eocene, California : Clark, 171.

Stonebreaker limestone, Carboniferous, Oklahoma : Bowen, 91.

Stonebreaker limestone, Pennsylvanian, Oklahoma: Heald, 423, 424.

Stonebouse formation, Silurian, Nova Scotia : McLearn, 611.

Stones River limestone, Ordovician, Maryland : Clark et al., 179.

Strawn division, Carboniferous, Texas: Drake, 266.

Strawn formation, Pennsylvanian, Texas : Kempher, 504.
Sucarnochee clay, Tertiary, Alabama: Hager, 387.

Sundance formation, Jurasstc, Great Plains: Schuchert, 830.

Sunlance formation, Jurassic, South Dakota : Darton, 228.

Sundance formation, Jurassic, Wyoming : Bowen, 88 ; Condit, 202 ; Wegemann, 1010.

Sunderland formation, Quaternary, Maryland : Clark et al., 179.

Sunderland group, Quaternáry, Maryland : Little, 577.

Supai formation, Carboniferous, Arizona : Schuchert, 828.

Sycamore limestone, Oklahoma: Cullen, 213.

Sylamore sandstone, Mississippian, Missouri : Branson, 102.

Talbot formation, Quaternary, Maryland: Clark et al., 179 ; Little, 577.

Tallahatta bubrstone, Tertiary, Alabama : Hager, 387.

Tallahatta buhrstone, Tertlary, Mississippi : Matteson, 634.

Talpa bed, Carboniferous, Texas: Drake, 266.

Talpa formation, Permian, Texas: Poede and Waite, 59.

Tamasopa limestone, Cretaceous, Mexico: Dumble, 271.

Tanlajas formation, Tertiary, Mexico ; Dumble, 271.

Tar Springs sandstone, Mississippian, Kentucky and Illinois: Butts, 140; Ulrlch, 962.

Taylor marl, Cretaceous, Texas: Stephenson, 909 .

Teapot sandstone member, Cretaceous, Wyoming: Wegemann, 1010.

Tecumseh shale member, Pennsylvanian, Kansas: Moore and Haynes, 697.

Tellico sandstone, Ordovician, Tennessee : Stose and Schrader, 923.

Temapache limestones, Tertiary, Mexico: Dumble, 271.

Tensleep sandstone, Carboniferous, Wyoming : Condit, 202.

Tepeats sandstone, Cambrian, Arizona: Schuchert, 829.

Tesnus formation, Pennsylvanian, Texas: Baker and Bowman, 32.

Tessey formation, Permlan, Texas: Udden, 959.

Teton formation, Triassic, Montana : Condit, 202.

Texada formation, Carbonlferous, British Columbia : Burwash, 135.

Texana beds, Cretaceous, Texas: Drake, 266.

Thaynes limestone, Triassic, Wyoming and Idaho: Schult\%, 833.

Thermopolis shale, Cretaceous, Wyoming: Bowen, 88; Moody and Taliaferro, 688 .

Thomonde beds, Tertiary, Iaiti: Jones, $4 ! 90$. 
Thorntoin fire clay, Pen'nsylvanian, West Virginia : Reger and Teets, 778.

Thorold sandstone, Sllurian, New York: Chadwick, 158.

Threeforks formation, Devonian, Wyoming: Schuiltz, 833.

Tichenor limestone, Devonian, New York: Grabau, 355.

Tiffany beds, Eocene, Colorado: Granger, 357.

Timiskaming group, pre-Cambrian, Quebec: Wilson, 1058 .

Timiskaming series, pre-Cambrian, Quebec: Wilson, 1058.

Tivola tongue, Eocene, Georgia : Cooke and Shearer, 206.

Todilto (?) formation, Jurassic, Utah : Emery, 288.

Tokio sand member, Cretaceous, Arkansas : Miser and Purdue, 680.

Tomstown limestone, Cambrian, Maryland: Clark et al., 179.

Tonoloway formation, Silurian, Maryland : Clark et al., 179.

Tonoloway limestone, Silurian, Pennsylvania : Butts, 1.42.

Tookcarak diabase, pre-Cambrian, Belcher Islanḋs; Canada: Moore, 693.

Topeka limestone member, Pennsylvaanian,

- Kansas: Moore and Haynes, 697.

Torpedo sandstone, Carboniferous, Oklahoma: Clark, 174 ; Hopkins, 454.

Tradewater formation, Pennsylvanian, Kentucky : Lee, $\mathbf{5 5 2}$.

Trenton limestone, Ordóvician; Pennsylvania: Butts, 142.

Trenton limestone, Ordovician, Wisconsin : Alden, 8.

Trickbam bed, Carboniferous, Texas: Drake, 266.

Trinidad sandstone, Cretaceous, Colorado, New Mexico: Lee, 554 .

Trinity conglomerate, Cretaceous, Texas: Drake, 266.

Trinity formation, Cretaceous, Arkansas : Miser and Purdue, 679, 680.

Trinity sand, Cretaceous, Texas and Oklahoma: Stephenson, 909.

Trinity sands, Cretaceous, Texas: Drake, 266.

Tully limestone, Devonian, New York: Grabau, 355.

Turkey Run limestone, Carboniferous, Oklahoma: Heald and Mather, 425.

Tuscarora formation, Silurian; Maryland : Clark et al., 179.

Tuscahoma formation, Tertiary, Alabama : Hager, 387.

Tuscarora quartzite, Silurian, Pennsylvania: Butts, 142.

Tuscaloosa formation, Cretaceous; Alabama: Hager, 387.

Tuxedni sandstone, Jurassic, Alaska: Chapin, 168.

Tuxpam beds, Tertiary, Mexico: Dumble, 271.
'I'wo Medicine formation, Cretaceous, Montana : Stebinger, 915.

Twiggs clay member; Eocene, Georgla : Cooke and Shearer, 206.

Twin Creek limestone, Jurassic; Wyoming and Idaho: Schultz, 833.

Uffington shale, Pennsylvanian, 'West Virginia : Reger and Teets, 778.

Uinta formation, Tertiary, Utah: Winchester, 1066.

Ulsterian group, Devonian, Tennessee : Dunbar, 273.

Ultima Thule gravel lentil,.. Cretaceous, Arkansas: Miser and Purdue, 679, 680.

Umpqua formation, Eocene, Oregon : Smith, 884.

Unicoi formation, Cámbrian, Virginia : Hewett et $a l ., 433$.

Uniontown limestone, Pennsylvaniạ, West Virginia: Reger and Teets, 778 .

Uniontown sandstone, Pennsylvanian, Vitest Virginia: Reger and Teets, 778.

Unkpapa sandstone, Jurassic, South Dakota : Darton, .228.

Vale formation, Permian, Texas : Beede and Waite, 59.

Valera bed, Carboniferous, Texas: Drake, 266.

Vallenar formation,: Devonian; Alạska: Chapin, 167.

Vanhornsville sandstone, Silurian, New York: Chadwick, 158.

Vaqueros sandstone, Miocene, California: English, 294.

Vashon till, Pleistocene, British Columbia : Burwash, 135.

Vermejo formation, Cretaceous, Colorado, New Mexico: Lee, 554.

Verona iron ore, Silurian, New York: Chadwick, 158.

Vicksburg group, Tertiary, Mississippi : Cooke, 205 .

Vicksburg limestone, Tertiary; Gulf coasst : Matteson, 634.

Victoria sandstone, Cretaceous, Alberta : Allan, 12.

Vidrio Pormation, Permian, Texas Udden, 959.

Vilas shale member, Pennsylvanian, Kansas : Moore and Haynes, 697.

Vinales limestones, Jurassic, :Cuba: DeGolyer, 241.

Viola limestone, Oklahoma: Cullen, 213.

Virgelle sandstone, Cretaceous, Montana : Stebinger, 915.

Virginia slate, pre-Cambrian, Minnesota: Harder and Johnston, $403 . \quad \therefore$. .'

Vishnu formation, :Archean, Arizona : Schuchert, 829.

Wabaunsee formation; Pennsylvanian, Kansas: Moore and Haynes, 697.

Wabaunsee formation, Pennsylvanian, Missouri : Branson, 102.

Waldrip bed, Carboniferous, Texas : Drake, 266. 
Wall Creek sandstone member, Cretaceous, Wyoming : Wegemann, 1010.

Walnut "shale member, Pennsylvanian, Kansas: Moore and Haynes, 697.

Walnut shaly member, Cretaceous, Texas and Oklahoma: Stephenson, 909.

Wanipigow series, pre-Cambrian, Manitoba: Marshall, 621.

Wapanucka limestone, Oklahoma: Cullen, 213.

Warrior limestone, Cambrian, Pennsylvania : Butts, 142 .

Warsaw formation, Mississippian, Missouri and lowa: Van Tuyl, 972.

Warsaw limestone, Mississippian, Kentucky and Illinois: Butts, 140.

Warsaw shales, Mississippian, Missourl: Branson, 102.

Wasatch formation, Tertiary, Utah : Clark. 175 ; Winchester, 1066.

Wasatch formation, Tertlary, wyoming: Moody and Taliaferro, $6 \varsigma 8$.

Wasatch formation, Eocene, Wyoming: Wegemann, 1010.

Washita group, Cretaceous, Texas and Oklathoma: Stephenson, 909.

Watauga shale, Cambrian, Virginia: Hewett et al., 433.

Watt's Creek bed, Carboniferous, Texas: Drake, 266.

Waubakee dolomite, Silurian, Wisconsin: Alden, 8 .

Waukesha beds, Silurian, Wisconsin : Al den, 8.

Waynesboro formation, Cambrian, Pennsylvania : Butts, 142.

Waynesboro shale and sandstone, Cambrian, Maryland: Clark et al., 179.

Weber quartzite, Pennsylvanian, Utah : Schultz, 834

Weisner. quartzite, Cambrian, Georgia : Shearer, 858.

Welch sandstone, Pennsylvanian, West Virginia: Reger and Teets, 778.

Wellington formation, Permian, Kansas : Moore and Inaynes, 697.

Wellington shales, Permian, Kansas: Perrine, 751 .

Wells fornation, Carboniferous, Wyoming and Idaho: Schultz, 833.

Weno clay member, Cretaceous, Texas: Stephenson, 909.

Westerly granite, Rhode Island: Hawkins, 412.

Weston sandstone, Pennsylvanian, West Virginia: Reger and Teets, $\mathbf{7 7 8}$.

Weston shale member, Pennsylvanian, Kansas: Moore and Haynes, 697.

Weverton sandstone, Cambrian, Maryland : Clark et al., 179.

Whirlpool sandstone, Silurian, New York: Chadwick, 158.

Whitehorse sandstone, Carboniferous, Oklahoma : Ohern, 718.
Whitehorse studstone member, Permian, Kansas: Moore and Haynés,' 697.

Whitehorse sindsistone member, "Permian' Oklahoma : Aurin, 27.

Whitemud beds, Eocene, Saskatchervan : Davis, 233.

White Pine shale, Mississippian, California : Kirk, 519.

White River formation, Oligocene, North Dakota: Quirke, 772.

White River group, Tertiary, South Dakota: Darton, 228.

Whitewood limestone, Ordovician, South Dakota : Darton, 228.

Wichita stage, Fermian, Texas: Beede and White, 59.

Witchita-Albany formation, Permian, Texas: Kempher, 504.

Wicomico formation, Quaternary, Maryland: Clark et al., 179; Little, 577.

Wilbarger Creek bed, Carboniferous, Texas : Drake, 266 .

Wilcox formation, Tertiary, Gulf coast: Matteson, 634.

Wilcox group, Tertlary, Alabama: Hager, 387.

Wild Forse limestone, Pennsylvanian, Oklahoma: Greene, 363 .

Willard shale member, Pennsylvanian, Kansas: Moóre and Haynes, 697.

Williamson shale, Silurian, New York: Chadwick, 158.

Wills Creek formation, Silurian, Maryland: Clark et al., 1.79.

Wills Creek shale, Sulurian, Pennsylvania : Butts, 142.

Windom shale, Dévonian, New York: Grabau, 355 .

Winfield limestone, Oklahoma : Cullen, 213.

Winfield limestone member, Permian, Kansas: Moore and Haynes, 697.

Wingate, Jurassic, Utah: Emery, 288.

- Winterset limestone, Pennsylvanian, Missouri: McCourt, 606; Wilson, 1057.

Winterset limestone member, Pennsylvanian, Kansas: Moore and Haynes, 697.

Wisconsin glaciation, Pleistocene, Wisconsin : Alden, 8.

Wise formation, Pennsylvanian, Virginia : Hinds, 439.

Wissahickon phyllites and schists, Ordovician (?), Maryland: Clurk et al., 179.

Wolcott limestone, Silurian, New York: Chadwick, 158.

Wolcott Furnace iron ore, Silurian, New York: Chadwick, 158.

Wolfcamp formation, Permian (?), Texas : Udden, 959.

Wolfe City sand member, Cretaceous, Texas: Stephenson, 909.

Woodbine sand, Cretaceous, Texas and Oklahoma: Stephenson, 909 .

Woodside formation, Triassic, Wyoming and Idaho: Schultz, 833.

Woodstock member, Tertiary, Maryland : Little, 577. 
Woolward formation, Carboniferous, Oklahoma: Ohern, 718.

Woodward formation, Peírian, Kansas: Moore and Faynes, 697.

Woodward formation, Permian, Oklahoma : Aurin, 27.

Woonsocket Basin series, Carboniferous, Rhode Island: Hawkins, 412.

Word formation, Permian, Texas: Udden. (5).

Wreford limestone, Carboniferous, Oklahoma : Bowen, 91; Cullen, 213.

Wreford limestone, Permian, Kansas: Per: rine, 7.11 .
Wreford limestone member, Permian, Kansis: Moore and Haynes, 697.

Yakima basalt, Tertiary, Washington : Schwennesen and Meinzer, 837.

Yankeetown chert, Miśsissippian, Illinois : Ulrich, 962.

Yazoo clay member, Alabama and Mississippi : Cooke, 205.

Yegua formation, Tertiary, Texas: Matteson, 634.

Yumuri limestone, Oligocene, Cuba: DeGolyer, 241.

ADDITIONAI, COPIES

OF tuis PUibLICATION MAY BE PROCURED FROM THE SUPERINTENDENT OF DOCUMENTS

GOVERNMENT PRINTING OFFTCE

WASHINGTON, D. C.

AT

10 CENTS PER COPY

$\nabla$ 